\author{
UNIVERSIDADE DE SÃO PAULO \\ MUSEU DE ARQUEOLOGIA E ETNOLOGIA \\ PROGRAMA DE PÓS-GRADUAÇÃO EM ARQUEOLOGIA
}

MARIA ESTER FRANKLIN MAIA SILVA

\title{
SÍTIO LIMEIRA, GUARAPARI /ES A RECONSTITUIÇÃO DE UMA PAISAGEM
}

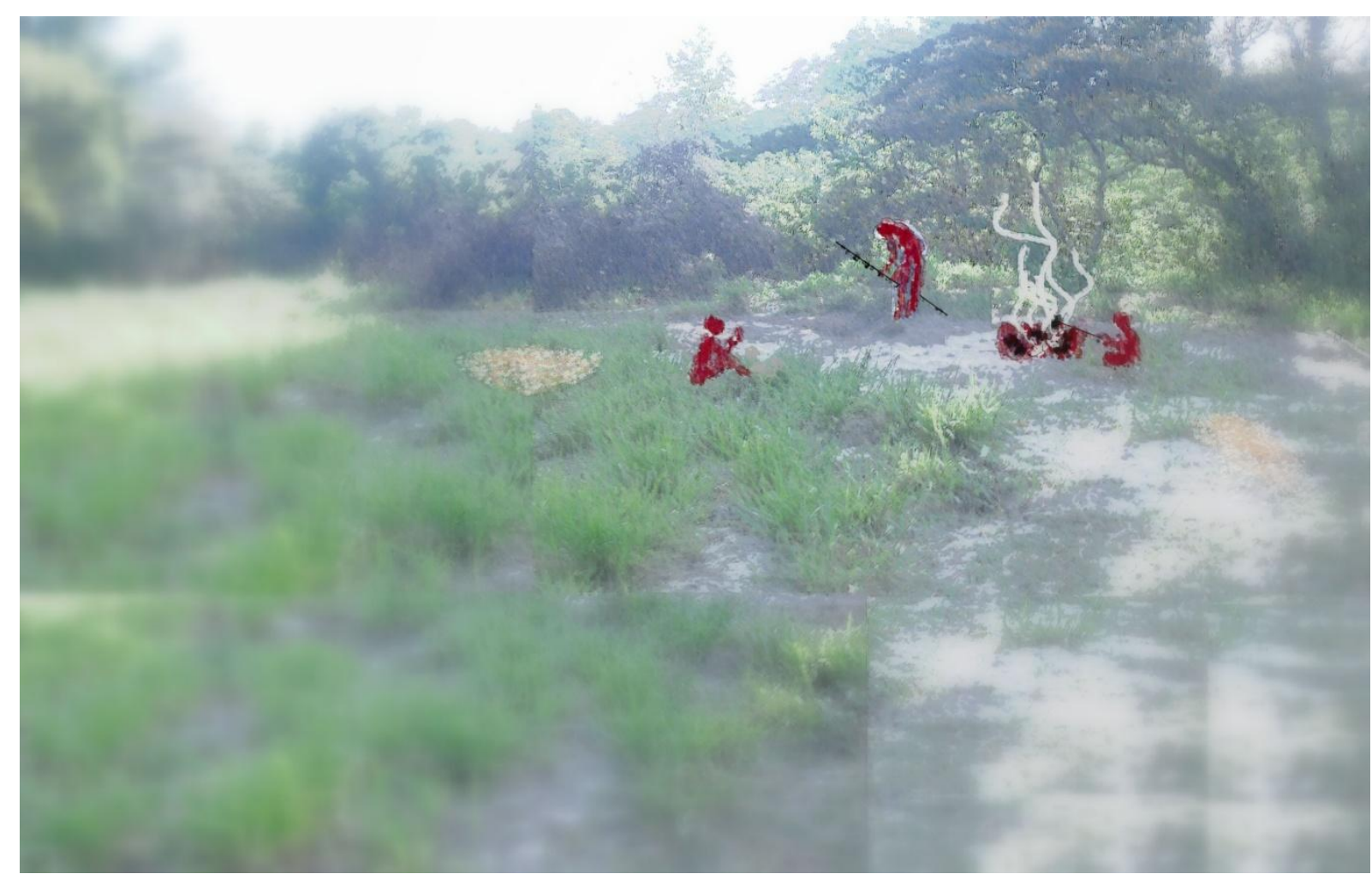

SÃO PAULO 


\section{SÍTIO LIMEIRA, GUARAPARI /ES A RECONSTITUIÇÃO DE UMA PAISAGEM}

Dissertação apresentada ao Programa de Pós-Graduação em Arqueologia do Museu de Arqueologia e Etnologia da Universidade de São Paulo para a obtenção do título de Mestre em Arqueologia.

Versão corrigida

A versão original encontra-se na bilblioteca do MAE

Orientadora: $\quad$ Profa Drª Márcia Angelina Alves

Linha de Pesquisa: Arqueologia e Ambiente 


\title{
SÍTIO LIMEIRA, GUARAPARI /ES A RECONSTITUIÇÃO DE UMA PAISAGEM
}

Dissertação submetida à avaliação da banca examinadora abaixo listada, como requisito obrigatório para a obtenção do título de Mestre em Arqueologia pelo Programa de Pós-Graduação em Arqueologia do Museu de Arqueologia e Etnologia da Universidade de São Paulo.

\author{
Prof $^{\mathrm{a}} \mathrm{Dr}^{\mathrm{a}}$ Márcia Angelina Alves \\ MAE/USP - Orientadora/presidente - 1ํmembro
}

Prof. Dr. José Luiz de Morais (MAE-USP)

MAE/USP - $2^{\circ}$ membro

Prof. Dr. Evaristo Goulart

IPT /USP - 3ำ membro

\section{Suplentes:}

1ํs suplente: Prof. Dr. Paulo Antônio Dantas DeBlasis (MAE-USP)

2 o suplente: Prof. Dr. Luiz Carlos Ruiz Pessenda (CENA-USP)

$3^{\circ}$ suplente: Prof ${ }^{\underline{a}} \mathrm{Dr}^{\mathrm{a}}$ Ana Luiza Vietti Bitencourt (UNIFESP - Campus Diadema) 
À minha mãe, Maria de Lourdes Franklim; exemplo de força, persistência e fé. 


\section{AGRADECIMENTOS}

Uma pesquisa acadêmica exige de seu (ua) autor(a) elementos como disciplina, dedicação, concentração, tempo, recursos e até mesmo renúncias e lágrimas. Porém, para vencer todos os desafios impostos para a realização desse tipo de estudo, é imprescindível que ao lado do pesquisador estejam pessoas e instituições, que, de forma consciente ou não, Ihe conferem o apoio necessário para transpor tempestades e calmarias, tornando possível a realização de seu trabalho científico em todas as suas etapas.

Portanto, primeiramente, devo agradecer à minha orientadora, a Prof $\stackrel{a}{\text {. D D }}{ }^{\text {a }}$. Márcia Angelina Alves, por toda a sua paciência, dedicação, aconselhamentos, lembranças e lembretes. Por suas palavras amáveis, mas também pela duras, tão necessárias para o crescimento pessoal de um ser humano em formação; o que o somos todos, por toda a vida.

Sou grata também à CAPES, cujo programa de bolsas de estudos gerou recursos que tornaram possível a realização desta dissertação de Mestrado, e também à SAS-USP, na pessoa da Assistente Social Eliane de Souza Queiroz, cuja paciência, compreensão e altruísmo foi imprescindível para a minha sobrevivência durante esse período.

Agradeço ao Prof. Dr. Paulo Antonio Dantas de Blasis (MAE-USP) por me fazer sentir à vontade no "Laboratório de arqueologia regional - MAE/USP", ao Prof. Dr. Astolfo de Mello Araújo (MAE-USP) pela ajuda no tão complicado início da análise dos elementos líticos, mesmo em meio à sua agenda lotada, ao Dr. Fábio Parenti (Presidente do Istituto Italiano di Paleontologia Umana - Roma, Itália), por me oferecer boas dicas, boa bibliografia, autoconfiança e parte de seu tempo curto, ao Prof. Dr. Marcelo Fagundes (Laboratório de Arqueologia da Paisagem-UFVJM), pelo imenso auxílio e disponibilidade na análise e processamento de desenhos do material lítico, e ao Prof. Dr. Luis Carlos Ruiz Pessenda (CENA-USP), pela transmissão de conhecimento e por me possibilitar tornar viva a alma dessa pesquisa.

À equipe do Laboratório de sedimentologia da Universidade Federal do Espírito Santo devo o meu agradecimento pelo apoio logístico através da disponibilização de espaço para guarda e análise dos vestígios arqueológicos coletados, assim como 
devo agradecer a ajuda oferecida por Yuri Batalha (IPHAN - ES) e do Prof. Ms. Celso Perota com os relatórios e licenciamento para intervenção arqueológica.

Muita gratidão aos meus amigos Flávio Tamogi Utida Júnior, pelo suor e ajuda no "ponta pé" inicial; Edson Kendy Osako, pois é muito bom poder escavar e comer uma incrível comida japonesa como recompensa (Domo arigatou gozaimashita!); Julio César Souza da Cunha, pelas horas e horas de trabalho duro e caminhadas infindáveis; e novamente às minha irmãs Mariana e Suzana e à minha mãe, Maria de Lourdes pela ajuda no trabalho intensivo campo. Porém, devo agradecer principalmente, ao meu querido amigo Luis Henrique Albernaz Sirico; sem seu direcionamento, paciência, força de vontade e amizade tudo seria muito mais difícil! Foi e sempre será um prazer para mim trabalhar ao seu lado. Você foi o meu "esteio de aroeira"; conte comigo sempre e em tudo!

Agradeço imensamente o apoio oferecido pela minha família, principalmente à minha mãe, Maria de Lourdes Franklin Maia, que sempre me permitiu e incentivou a acreditar nos meus desejos, meus sonhos e na minha capacidade de realiza-los a partir de minha força interior e esforços; à minha irmã Suzana, por sua admiração sincera; ao meu irmão Paulo, pela ajuda; à minha irmã Mariana, pelo apoio vital e por me emprestar seu talento na confecção dos maravilhosos desenhos e otimização dos mapas contidos nesta dissertação.

Também em minha família, devo agradecer ao meu tio, Benedito Franklin e sua família, pela acolhida inicial ao chegar em São Paulo; à minha querida "tia Bete", por ser minha mãe durante o período no qual abriu sua casa e seus braços para mim, me oferecendo um lar, um colo e todo o seu amor. Sou grata também às minhas tias Maria Aparecida Franklin, pela fé, apoio e confiança em mim; Maria da Penha Franklin, pela ajuda nos momentos difíceis e Jaqueline Franklin, pelas palavras e ações que tanto me ajudaram a me manter inteira em fases dilacerantes.

Devo a minha mais sincera gratidão aos queridos amigos do MAE, Ana Paula Berto e Wagner Magalhães pelo apoio e palavras amigas, e ao o Mestre quase Doutor Claudio Walter Gomes Duarte e o futuro Mestre Rodrigo de Lima, por me estenderem os braços e emprestarem seus ouvidos. Sem o seu apoio, paciência, compreensão, palavras e ações, talvez eu não conseguisse encontrar dentro de mim a força necessária para seguir em frente, e de cabeça erguida, transpondo limites inimagináveis e finalmente cumprindo essa missão pessoal. 
Reconheço também a ajuda imprescindível de meu amigo Ektor Mattos de Almeida e minha mãe japonesa Maria de Fátima Nishiuchi Sheu. Sem o seu incrível apoio teria sido ainda mais difícil concluir essa pesquisa.

Sou imensamente grata a toda a equipe da Biblioteca do MAE-USP, principalmente a Eleuza Gouveia, pelos abraços e energia positiva; ao Alberto Blumer Bezerra, pelo imenso apoio; ao Washington Urbano Marques Junior pelas boas gargalhadas para diminuir a tensão; e ao nosso Oráculo, Helio Rosa de Miranda, que sabe incrivelmente sobre tudo e está sempre pronto para encontrar, recomendar e providenciar qualquer bibliografia que precisemos!

Aos meus amigos Pedro Hayashi, Moriyama Hiromichi e Fabiana Ribeiro, e meu Sensei, o Monge budista Yodo Okuda, meus sinceros agradecimentos pela ajuda espiritual através das palavras e do silêncio, me ajudando a manter a serenidade, a tranquilidade e a autoconfiança, sempre tendo em mente as palavras do Buda Shakyamuni e do Mestre Nichiren Shonin.

Muita gratidão aos meus amigos, o casal Kiyoshi e Misa Sakamoto e minha irmã de alma Railene, pela ajuda em todos os aspectos durante o Mestrado. Sua amizade e carinho foram imprescindíveis!

Agradeço também a todos os membros do grupo Sul Fiato do Coral/USP, principalmente à regente Paula Cristina Monteiro e aos maravilhosos cantores Rubens Prince Alves e Silvia Navarro pelas palavras abraços e apoio para a materialização desta dissertação.

A dedicação e paciência diante de meus esquecimentos por parte de Cleberson Henrique de Moura e Regina Estela Leopoldo e Silva também devem ser lembradas com muito carinho. Formulários, assinaturas, requerimentos...um "mar" de papéis que se tornaram muito menos complexos com ajuda de vocês.

Finalmente, e não menos importante, agradeço a Anthony Aaron Venezia (Columbia University), por me ajudar em todos os sentidos e a trazer de volta a crença de que eu posso caminhar para além dos aparentes limites da vida; você me mostrou que esta possui cores ainda mais numerosas e intensas do que se pode supor. 
A paisagem foi, e ainda é, ao mesmo tempo o palco e a obra de todos os espetáculos, permanecendo aqui e ali; silenciosa, porém dinâmica, esperando que algum dia possa ser compreendida para finalmente contar o que sabe sobre nós. 


\section{RESUMO}

A presente Dissertação estuda a ocupação pré-histórica do sítio Limeira, UTM 24K 341411 - 7714533 (40³1'20,62" O e 20³9'42,61" S); sítio arqueológico a céuaberto localizado no município de Guarapari, região do litoral centro-sul do Estado do Espírito Santo. A pesquisa arqueológica foi pautada nos pressupostos teóricometodológicos da Arqueologia da Paisagem, cadeia operatória e Habitus, evidenciando vestígios materiais líticos e malacológicos de uma população coletoracaçadora-pescadora que se estabeleceu no local há cerca de 670 anos AP $\left({ }^{14} \mathrm{C}-\right.$ CENA-USP). O foco da análise centrou-se na investigação da interação entre a população que habitou o sítio com o ambiente que a circundava, com levantamentos geológicos, geomorfológicos, hidrográficos, climáticos, etc., através de pesquisas bibliográficas e cartográficas. Também, buscou-se reunir informações sobre $O$ paleoambiente do litoral do Espírito Santo, com fulcro na região estudada. A pesquisa intensiva de campo foi realizada em 4 campanhas: uma em 2009, pelo Prof. Ms. Celso Perota, via resgate arqueológico, e as demais, de cunho acadêmico, realizadas entre os anos 2012 e 2013, voltadas para esta dissertação de Mestrado, pautadas nos métodos e técnicas de investigação de campo por superfícies amplas em decapagens por camadas naturais. Como resultado, foi possível observar que o sítio Limeira é unicomponencial, além de serem evidenciadas duas estruturas estabelecidas na forma de 3 bolsões malacológicos e uma fogueira, cujos carvões foram utilizados para realização de datação. Os dados analisados possibilitaram interpretações a respeito do modo de vida dos habitantes pretéritos do sítio Limeira, e dos aspectos ambientais (vegetação e clima) que os cercava. É importante destacar que o estudo dos vestígios arqueológicos do sítio em questão e sua inserção nas escalas espaciais, temporais e ambientais, estabeleceram parâmetros de suma relevância para que futuras pesquisas desenvolvidas no Espírito Santo encontrem referenciais de suporte.

PALAVRAS-CHAVE: Arqueologia da paisagem, paleoambiente, indústria lítica, paleoambiente, datação por $\mathrm{C}^{14}$, Guarapari-ES. 


\section{ABSTRACT}

This thesis studies the prehistoric occupation of Limeira, (UTM 24K 341411-7714533 - 40³1'20,62 "O 20³9'42,61 and" S); an open-air archaeological site located in the city of Guarapari, on the south-central coast of the state of Espírito Santo, Brazil. The research was based on theoretical and methodological assumptions of Landscape Archaeology and operational chains and Habitus, showing evidence of lithic and malacological remains of a hunter-gatherer-fisher population that settled in the area around 670 years ago (14C - CENA USP). The analysis is focused on investigation into the interaction between the population that inhabited the site and the surrounding environment, encompassing geologic, geomorphologic, hydrographic and climatic surveys as well as bibliographic and cartographic research. The study also sought to gather information on the coastal paleoenvironment of Espírito Santo, with the research area serving as the fulcrum. Intensive field work was carried out in four campaigns: one in 2009, by Prof. Msc. Celso Perota via archaeological rescue, and three others of academic nature, directly related to this thesis, performed between 2012 and 2013. All field research was guided by methods and techniques for large surfaces with stripping by natural levels. As a result, it was observed that the Limeira site is uni-componential. Also highlighted were two established structures in the form of 3 malacological pockets and a fire pit, whose coals were used to perform carbon dating. Once analyzed, the data allowed for interpretations regarding the way of life of past inhabitants of the Limeira site, and the environment (vegetation and climate) around them. It is important to note that the study of the archaeological remains of the site in question - as well as their insertion into spatial, temporal and environmental scales - has established relevant parameters so that future research in Espírito Santo can be developed and supported within a greater frame of reference.

KEYWORDS: Landscape Archaeology, paleoenvironment, lithic industry, ${ }^{14} \mathrm{C}$ dating, Guarapari-ES. 
ÍNDICE GERAL

\section{Capa}

Folha de rosto. I

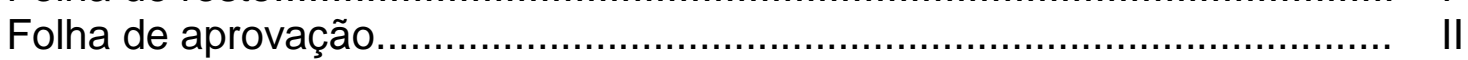

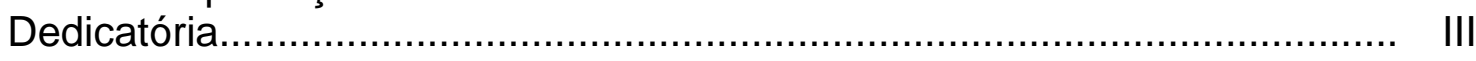

Agradecimentos........................................................................... IV

Epígrafe

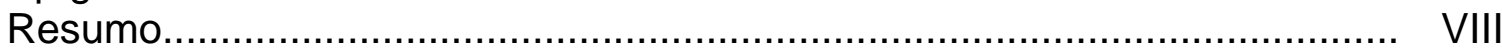

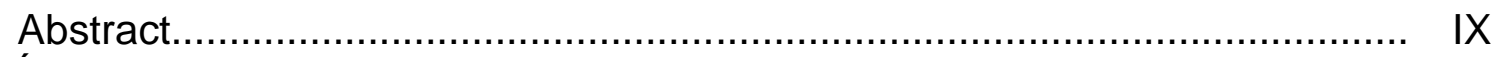

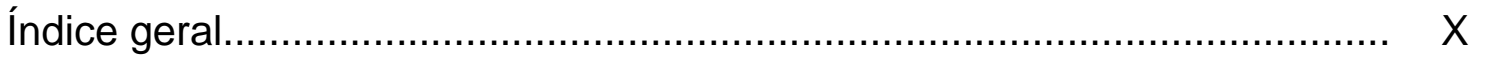

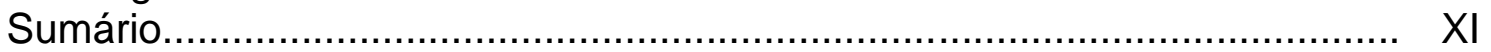

Lista de quadros .......................................................................... XIII

Lista de gráficos......................................................................... XIV

Lista de mapas............................................................................. XIV

Lista de Figuras.......................................................................... XV

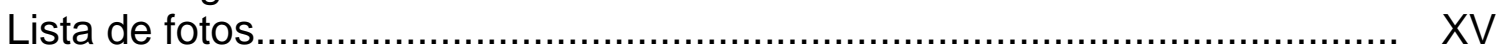

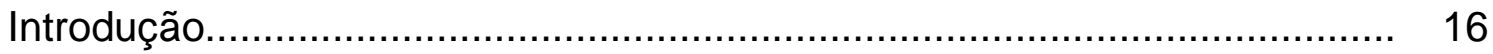

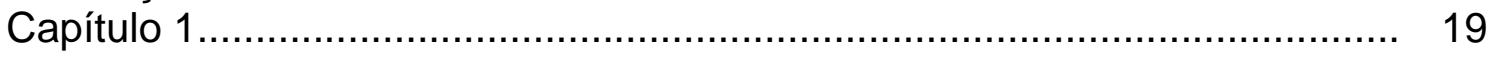

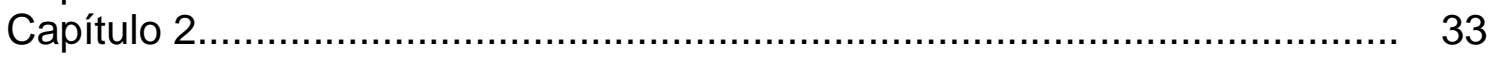

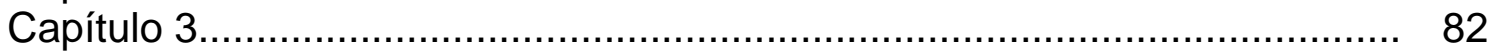

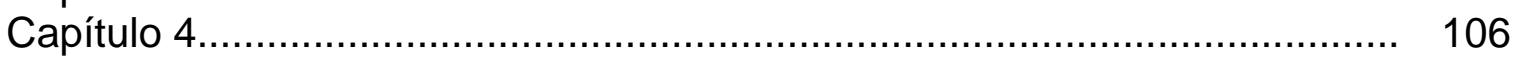

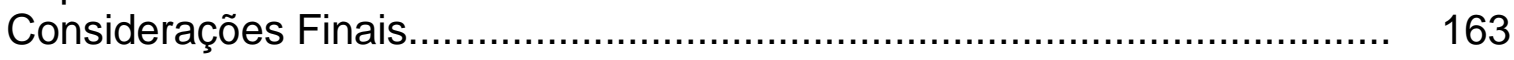

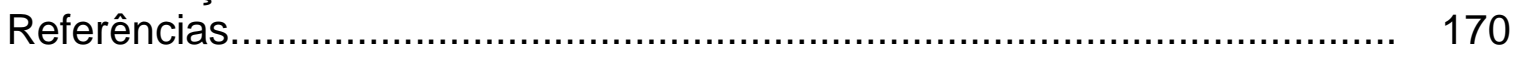

Anexos 


\section{SUMÁRIO}

INTRODUÇÃO.

Pressupostos teórico-metodológicos e técnicos

1.1 PAISAGEM E ARQUEOLOGIA DA PAISAGEM.

1.2 ANTROPOLOGIA DAS TÉCNICAS E A CADEIA OPERATÓRIA....... 28

1.3 HABITUS.

Paisagem e contexto ambiental do sítio Limeira

2.1 INSERÇÃO AMBIENTAL

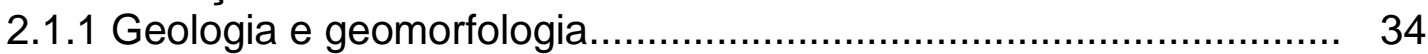

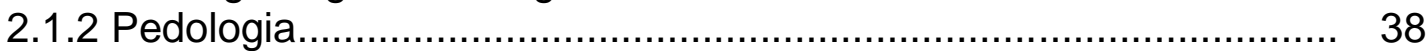

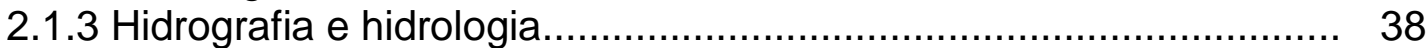

2.1.4 Clima e oceanografia ...................................................... 39

2.1.5 Cobertura vegetal............................................................ 41

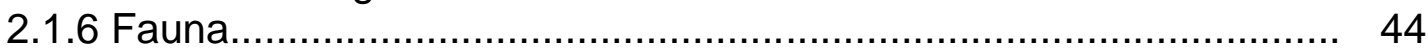

2.2. PALEOAMBIENTE DO LITORAL DO ESPÍRITO SANTO................ 46

2.2.1 O período Quaternário - Holoceno.............................................. 47

2.2.2 Ocupação humana no litoral brasileiro durante o Holoceno............. 50

Sambaquis marítimos..................................................................... 51

Acampamentos conchíferos....................................................... 56

Breve caracterização dos sítios litorâneos do Espírito Santo................. 59

Breve caracterização dos sítios litorâneos do Rio de Janeiro................ 62

Breve caracterização dos sítios litorâneos de São Paulo........................... 65

2.2.3 O paleoambiente do litoral do Espírito Santo................................. 69

2.3 CONTEXTO AMBIENTAL DO SÍTIO LIMEIRA............................... 71

2.3.1 Localização e contextualização.................................................... 71

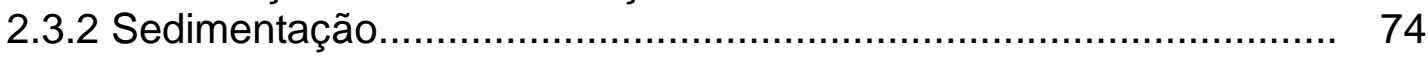

2.3.3 Sítio Limeira - ambientação......................................................... 75

Capítulo 3

Pesquisas arqueológicas: estratigrafia, estruturas e datação

3.1 MÉTODOS E TÉCNICAS EMPREGADOS NAS PESQUISAS DE CAMPO.

3.2 O RESGATE ARQUEOLÓGICO...

82

3.2.1 1 $1^{\text {a }}$ pesquisa de campo - resgate arqueológico via contrato............... 84

3.3 CAMPANHAS DE PESQUISA ACADÊMICA ................................. 87

3.3.1 1를 Campanha - setembro 2012 ................................................ 89

3.3.2 2 $2^{\mathrm{a}}$ Campanha - dezembro 2012.............................................. 95

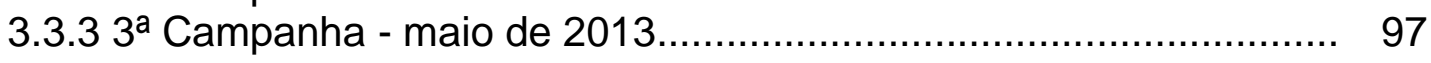

3.4 ESTRATIGRAFIA............................................................ 100 
3.5 ESTRUTURAS ARQUEOLÓGICAS............................................ 102

3.5.1 Bolsões malacológicos......................................................... 102

3.5.2 Estrutura de combustão - fogueira............................................. 105

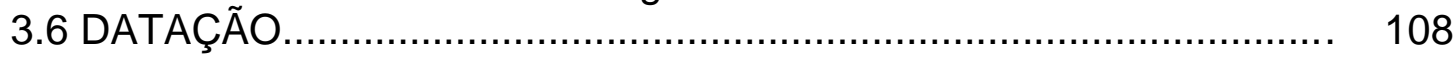

Capítulo 4

Análise dos vestígios arqueológicos do sítio Limeira

4.1 ANÁLISE DOS VESTíGIOS LÍTICOS............................................. 115

4.1.1. Metodologia de análise da indústria lítica.................................... 115

4.1.2 Características gerais da indústria............................................ 117

4.1.3 Matéria prima

4.1.4 Análise de grupo............................................................... 133

4.1.5 Análise tecnológica............................................................... 135

Debitagem ...................................................................... 136

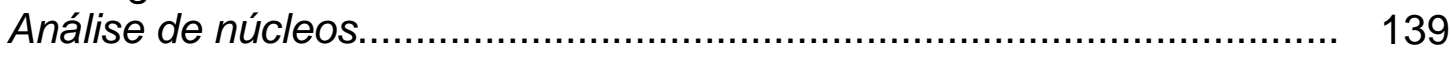

Análise de lascas...................................................................... 145

4.1.6 Análise tipológica................................................................ 155

4.1.7 Os procedimentos da manufatura - a cadeia operatória.................. 162

4.1.8 Distribuição espacial do material lítico........................................... 165

4.2 ANÁLISE DO MATERIAL MALACOLÓGICO................................. 167

4.2.1 Campanhas de trabalho intensivo de campo................................ 167

4.2.2 Características do material malacológico........................................ 169

CONSIDERAÇÕES FINAIS.......................................................... 172

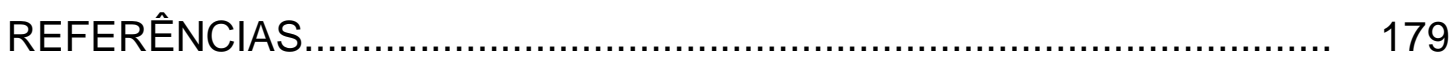

ANEXOS 


\section{LISTA DE QUADROS}

\section{Capítuo 2}

2.1 Características da vegetação dos ecossistemas restinga e manguezal.

\section{Capítulo 3}

3.1 Caracterização do perfil estratigráfico do sítio Limeira Setor 1.

3.2 Caracterização do perfil estratigráfico do sítio Limeira Setor 2.

3.3 Caracterização do perfil estratigráfico do sítio Limeira - campanha acadêmica.

\section{Capítulo 4}

4.1 Número de peças líticas coletadas por campanha...

4.2 Dados do material lítico coletado no Setor 1

4.3 Dados do material lítico coletado no Setor 2.

$4.41^{\text {a }}$ campanha, coleta de superfície.

$4.51^{\text {a }}$ campanha, $S 10$.

$4.61^{\text {a }}$ campanha, $\mathrm{S} 18$.

$4.72^{\mathrm{a}}$ campanha, limpeza de área...................................................... 120

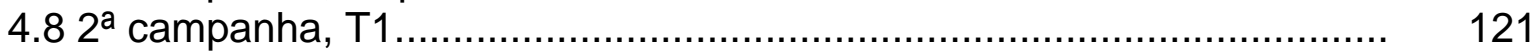

$4.92^{\mathrm{a}}$ campanha, T2 .................................................................. 121

$4.102^{\mathrm{a}}$ campanha, perfil estratigráfico..................................................... 122

4.11 Número de peças líticas contextualizadas e descontextualizadas........ 123

4.12 Quantidade de peças líticas por tipo................................................... 123

4.13 Quantidade de peças líticas por tipo................................................ 123

4.14 Tipo e distribuição de matéria prima no sítio Limeira............................. 124

4.15 Quantidade de peças em relação à superfície cortical......................... 131

4.16 Quantidade de peças corticais e sua classificação por tipo.................. 131

4.17 Variação das dimensões e pesos das peças líticas separadas por tipo.

4.18 Tipos de núcleo 133

4.19 Quantidade de peças preparatórias e utilizadas separadas por categoria.

4.20 Dimensões dos núcleos.

4.21 Aspectos formais dos núcleos do sítio Limeira.................................... 142

4.22 Quantidade e frequência de núcleos esgotados e não esgotados.......... 144

4.23 Dimensões das lascas do sítio Limeira............................................... 145

4.24 Relação entre comprimento e largura das lascas do sítio Limeira.......... 148

4.25 Relação entre comprimento e largura das lascas utilizadas do sítio Limeira.

4.26 Estado de superfície das lascas do sítio Limeira................................. 149

4.27 Relação entre os diferentes tipos de talão e o número de lascas........... 151

4.28 Lascas com talão liso-plano - relação entre o índice C x L e os ângulos 152 do talão.

4.29 Lascas com talão cortical - relação entre o índice C x L e os ângulos do 
talão

4.30 Dados quantitativos do material malacológico. Resgate arqueológico....

4.31 Material malacológico, $2^{\mathrm{a}}$ campanha, Perfil.

\section{LISTA DE GRÁFICOS}

\section{Capítulo 2}

2.1 Média anual de temperatura e de precipitação em Guarapari-ES

\section{Capítulo 4}

4.1 Distribuição espacial da matéria prima no sítio Limeira

4.2 Diferentes tipos de quartzo encontrados no sítio Limeira

4.3 Relação entre frequência e comprimento dos núcleos.

4.4 Relação entre frequência e largura dos núcleos.

4.5 Relação entre frequência e espessura dos núcleos.

4.6 Relação entre frequência e formas do núcleos.

4.7 Frequência de núcleos com relação aos aspectos corticais e formais.

4.8 Relação entre frequência e comprimento das lascas do sítio Limeira...

4.9 Relação entre frequência e largura das lascas do sítio Limeira...

4.10 Relação entre frequência e espessura das lascas do sítio Limeira..........

4.11 Relação entre núcleos e lascas corticais do sítio Limeira.

4.12 Relação entre núcleos e lascas iniciais do sítio Limeira

4.13 Frequência entre lascas de talão liso-plano por ângulo de lascamento e índice CXL

4.14 Frequência entre lascas de talão liso-plano por ângulo de chasse e índice $\mathrm{C} \times \mathrm{L}$

4.15 Frequência entre lascas de talão cortical por ângulo de lascamento e índice $\mathrm{C} \times \mathrm{L}$

4.16 Frequência entre lascas de talão cortical por ângulo de chasse e índice $\mathrm{C} \times \mathrm{L}$

\section{LISTA DE MAPAS}

\section{Capítulo 2}

2.1 Formação Barreiras ao longo do litoral do Espírito Santo.

2.2 Regime de ventos no Brasil em condições normais.

\section{LISTA DE FIGURAS}


Capítulo 2

2.1 Seção esquemática do sítio arqueológico Limeira em relação ao seu substrato geológico local.

2.2 Localização do sítio Limeira........................................................... 72

2.3 Inserção do sítio Limeira................................................................ 73

2.4 Localização dos costões rochosos observados em relação ao sítio Limeira................................................................................... 80

2.5 Localização da represa sobre o rio Jabuti........................................... 81

\section{Capítulo 3}

3.1 Planta baixa do sítio Limeira - Guarapari/ES. 92

$3.21^{\text {a }}$ campanha de pesquisa de campo acadêmica - set/2012. 94

$3.32^{\mathrm{a}}$ campanha de pesquisa de campo acadêmica dez/2012 96

$3.43^{\text {a }}$ campanha de pesquisa de campo acadêmica - mai/2014 99

3.5 Sítio Limeira - Seção esquemática do perfil estratigráfico. 103

3.6 Características da fogueira F1 .................................................... 107

3.7 Distribuição espacial do material arqueológico.......................................... 111

Prancha 4

Prancha 3

Prancha 2

Prancha 1

\section{LISTA DE FOTOS}

\section{Capítulo 2}

2.1 Costão rochoso com moluscos associados.

Capítulo 4

4.1 Material malacológico coletado no sítio Limeira. 


\section{INTRODUÇÃO}

A presente dissertação de Mestrado intitulada "Sítio Limeira, Guarapari/ES - a reconstituição de uma paisagem" tem como proposta o estudo da ocupação humana pré-colonial que se instalou na área hoje denominada sítio arqueológico Limeira (2039'42,61"S e 4031'20,62"O - UTM 24K 341411 - 7714533), datado em $670 \pm 65$ AP $\left({ }^{14} \mathrm{C}\right.$ - CENA-USP) e localizado no município de Guarapari, região centro-sul do estado do Espírito Santo, com foco na interação entre o Homem e o ambiente que o circundava.

O sítio Limeira é um assentamento temporário caçador-coletor-pescador a céu aberto, detectado, pesquisado e registrado junto ao IPHAN-ES entre os anos 2009 e 2010 pelo Prof. Ms. Celso Perota ${ }^{1}$, através de uma pesquisa de resgate arqueológico via contrato pela empresa EDP- Espírito Santo Centrais Elétricas SA (EDP-ESCELSA). Posteriormente, a pesquisa de campo no sítio Limeira foi retomada como base para elaborar esta Dissertação.

Com base nas perspectivas teóricas do conceito Arqueologia da Paisagem associadas a dados sobre o paleoambiente do período Quaternário na região estudada, buscou-se evidenciar as características do sítio Limeira sob uma perspectiva holística, com especial atenção à paisagem na qual está inserido através de suas particularidades e contexto ambiental circundante.

Para isso, foram consideradas as suas características paleoambientais, incluindo a análise de elementos como padrão de assentamento, o processo de formação do registro arqueológico e os padrões de mobilidade/ subsistência da população humana pré-histórica local, associados a estudos relativos à arqueofauna, datações e cultura material.

Este enfoque visou a compreensão da relação entre Homem e ambiente, para se obter dados arqueológicos, arqueofaunísticos e ambientais a nível do sítio Limeira, para compará-los com futuras escavações a serem desenvolvidas em outros sítios de coletores-caçadores-pescadores do litoral do Espírito Santo.

Dessa forma, e não menos importante, as análises também tiveram como alicerce as quatro campanhas de campo realizadas no sítio Limeira, sendo uma de

\footnotetext{
${ }_{1}^{1}$ Docente aposentado da Universidade Federal do Espírito Santo (UFES).
} 
resgate arqueológico realizada por Perota (2010), conforme já citado, e as demais de cunho acadêmico, voltadas exatamente para a realização desta Dissertação.

No capítulo 1, são abordados os principais pressupostos teórico-metodológicos e técnicos utilizados como embasamento para a realização desta Dissertação no que tange os temas: Arqueologia da paisagem, paisagem e território, com base principalmente nos trabalhos de Criado-Boado (1995; 1997; 1999); Morais (2011; 2012) e Santos (1978; 1997; 2005; 2008); cadeia operatória, com Leroi-Gourhan (1964-65), Balfet (1991) e Lemonnier (1980;1992); antropologia das técnicas de Mauss (1974a); habitus de Bordieu (1977; 1994 a e b).

Os enfoques metodológicos e técnicos abordados são os métodos de pesquisa de campo por superfícies amplas em decapagens por camadas naturais de LeroiGourhan (1950; 1964-65) baseadas no conceito Totalidade social de Mauss (1974b) e adaptadas às características do solo brasileiro por Luciana Pallestrini (PALLESTRINI \& PERASSO, 1984; ALVES, 2009), além dos procedimentos de investigação em arqueologia da paisagem propostos por Morais (2012).

O capítulo 2, refere-se ao contexto ambiental no qual está inserido o sítio Limeira, com a exposição das características da região, com dados geográficos, geológicos, geomorfológicos, pedológicos, hidrográficos, hidrológicos, biológicos, oceanográficos e climáticos. Além disso, estão dispostos dados paleoambientais do litoral sudeste com fulcro no Estado do Espírito Santo e regiões próximas ao sítio Limeira, tendo como base os trabalhos de Suguio (2003; 2005; 2010), Fairchild et al. (2009), Pessenda et al. (2012) Buso Jr. (2014) e Martin et al. (1997), abordando temas de suma relevância como caracterização do período Quaternário no Brasil, mais especificamente o Holoceno.

O capítulo 3 descreve as quatro campanhas de pesquisas arqueológicas de campo; a primeira realizada em 2009 por Perota e as demais voltadas para a coleta de dados para a presente pesquisa. Assim, o método adotado para a realização das três campanhas acadêmicas de pesquisa intensiva de campo foi o de superfícies amplas, com a técnica de decapagens por camadas naturais de Leroi-Gourhan (1950; 1964), centrados no conceito de totalidade social de Mauss (1974b) e adaptados ao solo tropical brasileiro por Pallestrini (1975). Além disso, os procedimentos de campo referentes à arqueologia da paisagem foram baseados nas técnicas propostas por Morais (2012). 
Nesse capítulo também são apresentados os resultados da pesquisa intensiva de campo realizada nas quatro campanhas, associados aos dados de estratigrafia, sedimentação, perturbações físicas e biológicas. Além disso, foram caracterizadas as estruturas arqueológicas detectadas e evidenciadas na forma de bolsões de material malacológico e a fogueira, além de serem apresentados os resultados da datação por ${ }^{14} \mathrm{C}$ realizada pelo Laboratório ${ }^{14} \mathrm{C}$ - CENA-USP.

O capítulo 4 exibe os resultados obtidos através das análises laboratoriais e estatísticas da indústria lítica e dos vestígios malacológicos pertencentes ao sítio Limeira, coletados sistematicamente através das quatro campanhas de pesquisa intensiva de campo. Tais análises foram embasadas nos conceitos de cadeia operatória, pautados em obras de André Leroi-Gourhan (1964-65), Heléne Balfet (1991) e Pierre Lemonnier (1980;1992) e na utilização das técnicas desenvolvidas e expostas por Brézillon (1968), Tixier (1980) Emperaire (1967), Pallestrini e Chiara (1978) e Morais (1987; 2007).

Nas Considerações Finais, é apresentada uma síntese da Dissertação; onde também são analisadas as contribuições, as limitações enfrentadas, as expectativas e as possibilidades de pesquisas futuras. 


\title{
Capítulo 1
}

\section{Pressupostos teórico-metodológicos e técnicos}

Neste primeiro capítulo são abordados os principais pressupostos teóricometodológicos e técnicos utilizados como embasamento para a realização desta dissertação de Mestrado no que tange os temas: paisagem, arqueologia da paisagem, antropologia das técnicas, cadeia operatória e habitus.

Os conceitos, autores e títulos utilizados são: paisagem, território e arqueologia da Paisagem, com base principalmente nos trabalhos de Santos (1978; 1997; 2005; 2008), Criado-Boado (1995; 1997; 1999) e Morais (2011; 2012); antropologia das técnicas de Mauss (1974a); cadeia operatória, com Leroi-Gourhan (1964), Balfet (1991) e Lemonnier (1980;1992); habitus de Bordieu (1977; 1994 a e b).

\subsection{PAISAGEM E ARQUEOLOGIA DA PAISAGEM:}

\author{
"Pois conquanto estejamos habituados a situar a \\ natureza e a percepção humana em dois campos \\ distintos, na verdade elas são inseparáveis. Antes de \\ poder ser um repouso para os sentidos, a paisagem é \\ obra da mente. Compõe-se tanto de camadas de \\ lembrança quanto de estratos de rocha."
}

(SCHAMA, 1995, p. 17)

Amplamente divulgado, discutido e teorizado, o estudo da paisagem é um importante aliado nas pesquisas arqueológicas; porém, de acordo com Bandeira (2008), somente recentemente houve o "amadurecimento de seu uso" e, em adição, pode-se afirmar que poucos são os estudos no Brasil que realmente se utilizam do conceito de paisagem como recurso na obtenção de dados e interpretação do registro arqueológico.

De acordo com Anchuetz et al (2001), já no século XIX questões ligadas ao conceito paisagem já começavam a ser discutidas sob os aspectos geográficos e 
sociais, como no caso de um debate liderado por Friederich Ratzel e Émile Durkhein². Conforme observado pelos autores, Ratzel, era geógrafo e adepto do determinismo geográfico, ou seja, defendia que o espaço era a extensão dos grupos humanos que o habitavam, sendo que estes diferenciavam-se entre si através das propriedades impostas por esse ambiente natural. Já para o sociólogo Durkheim, a relação do ser humano com seu ambiente natural se dá através do inconsciente coletivo formado por uma estrutura institucional.

O determinismo geográfico foi refutado por Franz Boas (2004a) após a realização de pesquisa entre os esquimós na terra de Baffin. Quando em busca de estudos a respeito dos efeitos do meio físico sobre a sociedade esquimó através da convivência direta com esse povo, Boas percebeu que na verdade a cultura era o maior determinante de sua organização social.

Em Arqueologia, conforme Hicks (2002), o interesse pela relação entre Homem e espaço iniciou-se com Fox em 1932, com a publicação de seu estudo de distribuição de diversos tipos de artefatos e a relação entre estes e a estrutura física da Terra, clima, flora e fauna. Mais tarde, ainda de acordo com este autor, Willey, em 1953, interessou-se em analisar padrões de assentamento.

Nos anos 1960, tal relação foi encarada de duas formas diferentes: sob os aspectos culturais, como resultado da interação entre ambiente e tecnologia e com foco em padrões de assentamento, que através de autores como Trigger, Renfrew entre outros, foram vistos como base para inferências de organizações sociais, políticas e religiosas de culturas pré-históricas. Hicks (2002) também observou que a partir da década de 1970 houve aumento no número de publicações em arqueologia da paisagem e maior esforço no desenvolvimento e aplicação de sua teoria ${ }^{3}$.

Dessa forma, é inevitável notar que o conceito paisagem, que é transdisciplinar, ao longo do tempo assumiu uma multiplicidade de significados derivados do enfoque de cada uma das áreas do qual é um fator importante de estudo, ou até mesmo da

\footnotetext{
2 Hirsch, E. Landscape: Between place and space. In Hirsch, E., and O'Hanlon, M. (eds.), The Archaeology of Landscape: Perspectives on Place and Space, Clarendon Press, Oxford, pp. 1-30. 1995.

${ }^{3}$ Fox, C. The Personality of Britain. Cardiff: National Museum of Wales. 1932.

Renfrew, C. Monuments, Mobilizationan and Social Organization in Neo-lithic Wessex. In: The Explanation of Culture Change, Renfrew, C. ed., pp. 39-558. London: Duckworth, 1973.

Trigger, B. G. The Determinants of Settlement Patterns. In: Settlement Archaeology, Chang, K. C. ed., pp.5 3-78. Palo Alto, C A:National Press (Mayfield). 1968.

Willey, G. Prehistoric Settlement Patterns in the Vird Valley, Peru. BAE Bulletin 155.Washington, DC:

U.S. Government Printing Office. 1953.
} 
visão de diferentes pesquisadores, o que também Ihe confere sua característica subjetiva. Porém, a Arqueologia é uma ciência que pode aplicar tal conceito de forma completa, integrativa; da maneira mais explícita e cabal, por possuir a propriedade de unir diversas ciências em si, o que inclui a geografia, geologia, biologia e a antropologia.

Anchuetz et al (2001) destacam que o conceito paisagem pode auxiliar a Arqueologia na busca pelo entendimento do passado do Homem pois facilita o reconhecimento e a avaliação da dinâmica da relação entre pessoas, o ambiente físico e o meio social através do espaço e do tempo. Além disso, tem a capacidade de conectar a prática e a teoria arqueológica, aumentando discussões de interpretação e manejo da herança cultural deixada pelos antepassados humanos. Porém, antes de se desenvolver o conceito paisagem, é importante evidenciar a diferença existente entre os termos lugar, espaço território e paisagem.

Para Santos (1997), os lugares são "combinações localizadas de variáveis sociais"; são objetos carregados de "uma parcela do dinamismo social total". Dessa forma, Santos (2005) afirma que o lugar se define através da união de uma tecnoesfera, ou mundos dos objetos (naturais ou antrópicos) e uma psicoesfera, ou ação. Cada lugar é caracterizado "tanto por sua existência corpórea quanto por sua existência relacional." Portanto, é seguro afirmar que o exame minucioso de lugares arqueológicos, envolvendo as mais diversas áreas de conhecimento, pode revelar importantes informações sociais e culturais.

Em relação ao espaço, na concepção de Santos (1978), trata-se de um conjunto de formas representativas de relações sociais do passado e do presente e por uma estrutura representada por relações que estão acontecendo e manifestam-se através de processos e funções. "O espaço é um verdadeiro campo de forças cuja formação é desigual. Eis a razão pela qual a evolução espacial não se apresenta de igual forma em todos os lugares" (SANTOS, 1978, p.122). É uma totalidade que contém e é contida (SANTOS, 2008).

Ainda em conformidade com Santos (1978), o espaço, além de instância social que tende a reproduzir-se, tem uma estrutura que corresponde à organização feita pelo Homem. É também uma instância subordinada à lei da totalidade, que dispõe de certa autonomia, manifestando-se por meio de leis próprias. Assim, o espaço organizado é também uma forma resultante da interação de diferentes variáveis: 
- o espaço social corresponde ao espaço humano, lugar de vida e trabalho; morada do homem, sem definições fixas;

- o espaço geográfico é organizado pelo homem vivendo em sociedade e, cada sociedade, historicamente, produz seu espaço como lugar de sua própria reprodução.

Segundo Santos (1997), a sociedade não se distribui aleatoriamente em um espaço, mas há uma seletividade histórica e geográfica decorrente da necessidade, que por sua vez é resultado de determinações sociais, fruto das necessidades e possibilidades da sociedade em um dado momento.

Conforme Santos (1978), a delimitação política ou ideológica de uma área na qual se identifica o espaço de uma sociedade constitui-se o território; "a utilização do território pelo povo cria o espaço". O território pode ser considerado como delimitado, construído e desconstruído por relações de poder que envolvem uma gama muito grande de atores que "territorializam" suas ações com o passar do tempo. No entanto, a delimitação pode não ocorrer de maneira precisa, pode ser irregular e mudar historicamente, bem como acontecer uma diversificação das relações sociais num jogo de poder cada vez mais complexo.

Por fim, a paisagem, conforme Santos (1997), é a combinação de objetos naturais e objetos de ordem antrópica, ou seja, objetos resultantes da acumulação de atividades de muitas gerações humanas. Assim como o espaço, a paisagem altera-se continuamente para poder acompanhar as transformações da sociedade. Dessa forma, a paisagem não é fixa, porém, alguns de seus elementos não mudam, ao menos aparentemente, enquanto a sociedade se altera, sendo esses as "testemunhas do passado".

De acordo com Criado-Boado (1991), existem ao menos três maneiras de se compreender o conceito de paisagem:

- empirista, na qual a paisagem surge como uma realidade já dada e que, por diferentes razões, acaba negando a si mesma;

- sociológica, que caracteriza a paisagem como meio e produto de processos sociais;

- culturalista, na qual a paisagem é interpretada como materialização das práticas sociais, tanto material quanto imaginária. 
Criado-Boado (1991) afirma que “(...) sólo el espacio entendido espacialmente permite valorar cada contexto social específico (...)" (p.12), e que o conceito de espaço adotado pela cultura do pesquisador é dotado de valores determinados por seu sistema de "saber-poder", não podendo ser utilizado para esboçar reflexões sobre o espaço em culturas diferentes da dele.

Importante observar que constatações parecidas foram realizadas por Franz Boas (2004b [1930]) em seu relativismo cultural, no qual o autor expressa que os seres humanos estão acorrentados às "amarras da tradição", ou seja, cada ser humano observa o mundo sob a perspectiva da cultura em que cresceu; dessa forma, cabe ao pesquisador procurar sempre relativizar suas noções, fruto de sua civilização e de seus valores.

De acordo com Criado-Boado (1999), território não é uma unidade natural ou física, mas uma construção política. Além disso, no caso de caçadores-coletores nômades ou semi-sedentários, o território é o local onde se assentava o grupo, podendo se "fundir" com o território de outros grupos. Dessa forma o território pode ser fragmentado e sofrer variações, o que o autor chamou de "territorialidad proteica".

Morais (2012) afirma que a paisagem é o "resultado do processo de artificialização do meio" por parte de atividades humanas, sofrendo constantes processos construtivos e reconstrutivos pela sociedade em evolução e que através do estudo da forma e evolução da paisagem construída pode-se chegar aos seus autores.

Esses conceitos também foram expostos de forma interessante por outros pesquisadores. De acordo com Tilley (1994), lugar é aludido a significados humanos, e sua singularidade é manifestada e expressada em experiências rotineiras e no subconsciente das pessoas. O significado de um lugar varia de indivíduo para indivíduo; está ligado à identidade.

Em relação ao espaço, em conformidade com Tilley (1994), trata-se de algo com maior nível de complexidade, e depende da existência de lugar. Sem lugar não há espaço. A complexidade de espaço reside no fato de haver diversas visões a respeito do mesmo. Resumidamente, existem diversas formas de se conceituar espaço: 
- espaço somático, o que pode ser percebido à volta (na horizontal, vertical, acima, abaixo, etc.);

- espaço perceptivo, captado pelos indivíduos em suas atividades diárias (perto, longe, por aqui, por ali);

- espaço existencial, que está em constante processo de produção e reprodução através de movimentos e atividades de membros de um grupo (envolve o sagrado, simbólico e mítico - o lugar no espaço existencial é o foco da produção de significados);

- espaço arquitetural, a criação de espaço tangível, visível e sensível (participação na criação e recriação, produção e reprodução do espaço existencial e profundos efeitos estruturantes no espaço perceptivo);

- espaço cognitivo, que proporciona a base para reflexão, teorização e entendimento.

Para Zedeño e Bowser (2009), lugar é onde ambiente, pessoas e significados convergem em múltiplas escalas, criando-se, nesse processo, um registro do comportamento humano, percepção e cognição. Através desses registros inseridos na paisagem, em Arqueologia, pode-se realizar a reconstrução e interpretação do passado humano. De acordo com as pesquisadoras, pessoas criam lugares através de sua interação com o natural e o sobrenatural. Elas conscientizam-se de suas experiências desenvolvendo referências espaciais para suas ações através da modificação das matérias e inscrições verbais e metafóricas, e assim desenvolvem o senso de lugar, constroem sua identidade e deixam sua herança cultural através dos registros arqueológicos.

Zedeño (1997) propõe que recursos naturais e formações geológicas formam a "paisagem natural", tudo o que for de origem humana constitui "paisagem cultural" e por fim, modificações humanas na paisagem natural são denominadas "ambientes construídos". Ainda conforme a autora, o termo paisagem "cultural" pode ser utilizado para designar a integração entre ambientes naturais e construídos. Dessa forma, paisagens também podem ser definidas como fruto de construções sociais e ideológicas.

A paisagem, de acordo com Ingold (1993), é produto de um sistema cultural estruturante e de interações organizacionais de pessoas com seu ambiente natural. Através de suas atividades diárias, crenças e valores, as comunidades transformam 
espaço físico em lugares significativos. Paisagens não são somente construções de populações humanas, mas o meio pelo qual elas sobrevivem e se sustentam.

Knapp e Ashmore (1999) afirmam que a paisagem somente existe em virtude do que é percebido, experimentado e contextualizado por pessoas. Em complemento, é necessário dizer, conforme Ingold (1993), que a paisagem não é uma "figura na imaginação que sobrevive através dos olhos da mente", mas "cada componente [seu] envolve a essência de totalidade das relações" humanas e naturais. Em adição, segundo Criado-Boado (1995), o registro arqueológico não existe isoladamente, mas está diretamente relacionado com seu contexto espacial e em todas as escalas e âmbitos das atividades humanas.

Conforme pôde ser observado, é inegável a importância da utilização do conceito paisagem como ferramenta para a interpretação do modo de vida de sociedades pretéritas. Porém, devido a sua subjetividade e pluralidade, sabe-se da dificuldade de uni-lo à teoria arqueológica, o que torna ainda mais complicada a inter-relação, de maneira consistente, do mesmo à prática em Arqueologia com desenvolvimento de métodos e aplicações ideológicas seguras que gerem interpretações confiáveis.

De acordo com Criado-Boado (1999), a investigação de espaços arqueológicos e análise da totalidade do registro arqueológico e cultura material são fundamentais para a reconstrução da existência de princípios de organização e, consequentemente, reconhecimento de códigos culturais subjacentes às novas formas de construção da paisagem. Tal elemento é de fundamental importância para o entendimento do passado dos seres humanos na Terra, já que é o reflexo de como os seres se relacionaram com o seu meio.

Uma forma de aplicação é o método de Análise Formal ou Morfológico descrito por Criado-Boado (1997;1999), o qual consiste em analisar as formas materiais concretas que constituem a paisagem, tanto naturais (fisiográficas) quanto artificiais (cultura material, monumentos) sem introduzir um sentido estranho aos mesmos.

Conforme Criado-Boado (1991), é necessário recuperar a unidade entre a natureza e o homem. Em sentido amplo, a arqueologia da paisagem trata das dimensões práticas e sociais das paisagens arqueológicas, portanto, é uma estratégia de trabalho que pode ser utilizada como uma ferramenta de gestão e estudo do registro arqueológico e permite ascender a aspectos que a arqueologia tem se aproximado genericamente (CRIADO-BOADO, 1995). 
Em adição, Morais (2012) afirma que o foco da arqueologia da paisagem é a reconstrução dos cenários das ocupações humanas através do estudo dos "processos de artificialização do meio" e dos cenários produzidos, baseando-se em matriz ambiental (meio físico-biótico) e ambiente construído (meio socioeconômico e cultural).

Segundo Anchuetz et al (2001), é necessário considerar três aspectos gerais da paisagem: como lar, como elemento ritual e como elemento de caracterização étnica. Ainda de acordo com esses autores, tais componentes enfatizam os diferentes aspectos de como os humanos definem, formam e usam o espaço, transformando-o em lugar; conferindo um significado específico a ele.

Além disso, é importante ter em mente que as pessoas ocupam o espaço não em termos modernos de subsistência ou apenas de forma simbólica. Isso faz com que o trabalho do arqueólogo seja de certa forma difícil, pois essa influência humana sobre o meio é um processo social situado em seu tempo e em parte deve ser entendido com os valores dados desse tempo (JOHNSON, 2006).

Além disso, a paisagem não é constante; ela sofre mudanças protagonizadas por variações culturais, climáticas, geológicas, biológicas, entre outros. Por isso, sob o aspecto temporal, de acordo com Hicks (2002), existe a tendência por parte de alguns pesquisadores de encarar a paisagem como "camadas" (paisagem Neolítica, paisagem da Era do Bronze, etc.), o que pode culminar em equívoco, já que a construção da paisagem é reflexo de processos culturais e a cultura, apesar de particular, é altamente dinâmica. Parafraseando Ingold (1993), “...landscape becomes a part of us, just as we are a part of it." Em adição, culturas não se estabelecem "com um passe de mágica", mas através de processos. Deve-se dar total atenção a esse aspecto.

De acordo com Johnson (2006), é preciso ter em mente que mudança não está fundamentalmente ligada a influência; que cada povo possui diferentes mentalidades. É necessário considerar o entendimento da intimidade com a terra; valores e mentalidades dos usuários das paisagens e lembrar-se de que 0 significado delas não era exclusivamente ou até mesmo necessariamente "simbólico" ou "ritual".

Dessa forma a interpretação de um espaço é possível somente através de uma análise holística, combinando forma, estrutura e função, ou seja, observando-se sua totalidade (SANTOS, 1997). 
Adicionalmente, em conformidade com Zedeño (1997), para se obter bons resultados em estudos de interação humana pretérita com o meio ambiente onde vivia, é necessário considerar o registro arqueológico em sua totalidade tanto em espaço quanto em tempo.

Assim, a boa pesquisa de campo em arqueologia da paisagem depende, dentre outros, do uso das geotecnologias, técnicas modernas para estabelecer, registrar e gerenciar paisagens e seus componentes; pois entender o ambiente no qual se insere um sítio arqueológico, construído e reconstruído em função do uso e da ocupação do solo, ajuda na interpretação do modo de vida pregresso (MORAIS, 2011).

Nesse aspecto, a transdisciplinaridade da Arqueologia é uma ferramenta poderosa. Encarar uma paisagem e seu contexto de ocupação e neles identificar os recursos geográficos, geológicos, biológicos, oceanográficos, antropológicos, arqueológicos, entre outros que poderão revelar diversas partes do complexo "quebra-cabeça" do registro arqueológico é fundamental para que se realizem interpretações arqueológicas de qualidade e produção de conhecimento de relevância.

É no contexto que se dá o entendimento e a partir daí, a interpretação. Portanto, deve-se trabalhar com um contexto específico para evitar a subjetividade. Além disso, dados são poderosos aliados na manutenção da objetividade do trabalho; 0 pesquisador deve manter o foco em quais são os questionamentos e respostas que pode levantar e obter através do registro arqueológico, dados de campo coletados meticulosamente e contextualizados, dados laboratoriais, dados estatísticos e domínio da teoria.

Porém, não cabe ao arqueólogo dominar os conhecimentos das mais diversas áreas, mas é preciso que o mesmo saiba os recursos que pode extrair através delas; que tenha o olhar apurado, sem preconceitos e conectado ao passado e ao presente.

Portanto, o objetivo da pesquisa arqueológica não deve (e nem pode) ser a exata reprodução de como viviam as sociedades, mas propor interpretações a respeito das mesmas, dando nexo ao registro arqueológico. Nesse sentido, a arqueologia da paisagem é uma importante aliada.

A arqueologia da paisagem já não mais pode ser considerada apenas uma ferramenta eletiva no estudo sobre o passado humano. É inegável a importância da 
paisagem nos processos culturais que ocorreram ao longo da existência da humanidade, que culminaram no "mundo dos Homens" que hoje conhecemos. Afinal, ela foi, e ainda é, ao mesmo tempo o palco e a obra de todos os espetáculos, e permanece aqui e ali; silenciosa, porém dinâmica, esperando que algum dia possa ser compreendida para finalmente contar o que sabe sobre nós.

\subsection{ANTROPOLOGIA DAS TÉCNICAS E CADEIA OPERATÓRIA:}

Sabe-se que, assim como na atualidade, não existiram entre os povos pretéritos apenas uma técnica de manufatura de seus objetos, sendo eles líticos, cerâmicos ou quaisquer outros, mas muitas. Tal multiplicidade técnica deve-se a escolhas, conscientes ou não, realizadas durante o processo de confecção do objeto; momento este que compreende desde a escolha/coleta da matéria-prima até o produto final, ou até mesmo a partir do momento da concepção do artefato por parte da (o) $\operatorname{artes}(\tilde{a}) 0$.

A interpretação dos significados que cercam a cultura material e a consequente revelação do modo de vida dos povos que já se foram depende não apenas de análises minuciosas e exaustivas do artefato em si e de seu contexto, mas de tentar enxergar, através desses fatores, o ser; o agente por trás do objeto; o seu criador.

Para que seja possível tal entendimento é necessária a compreensão das escolhas sociais que cercam esse contexto, e para tanto, realizar-se a análise da "cadeia operatória", ou seja, da sequência de operações executadas durante todo o processo de manufatura do objeto; da transformação da matéria em objeto.

Tal conceito foi introduzido pelo pré-historiador André Leroi-Gourhan (1964), baseando-se na obra "As técnicas corporais" de seu orientador Marcel Mauss (CARDOSO DE OLIVEIRA, 1979), onde observa-se que o corpo é o "primeiro e mais natural objeto técnico e, ao mesmo tempo, meio técnico do homem" (Mauss, 1974b), para encarar o instrumento como um mecanismo de exteriorização das capacidades tecnológicas e senso-motoras humanas, e que os gestos humanos são culturalmente determinados.

De acordo com Mauss (1974a), as técnicas são socialmente adquiridas através da educação e mantidas por gerações pelo processo de aprendizagem. Assim, para que se saiba porque certo indivíduo não usa determinado gesto e sim outro, é 
necessário buscar conhecimento acerca das tradições que impõem tal comportamento.

Em adição, conforme Lévi-Strauss (2003), tais comportamentos são oriundos de atividade social (técnica, econômica, ritual, estética ou religiosa) que podem ser transferíveis. Assim, é correto afirmar que qualquer comportamento é adquirido através de interações sociais, o que não é exceção para comportamentos técnicos.

Diante disso, Leroi-Gourhan (1964) então relacionou "as técnicas corporais" às técnicas observadas em objetos pré-históricos, afirmando que "o utensílio só existe realmente no gesto que o torna tecnicamente eficaz". Dessa forma, o estudo das técnicas não pode se limitar na simples descrição do objeto.

A cadeia operatória então seria um encadeamento de fatos, definidos pelas técnicas, em que as operações são interdependentes e dependentes ao longo de um processo que busca um resultado específico. Mas então, o que seria "técnica"?

Com base em Leroi-Gourhan (1964), Lemonnier (1980) define técnica como a ação sobre a matéria que deve ser abordada sob três aspectos: a sequência de ações e operações, ou seja, os processos técnicos; em relação ao objeto, ou através de medidas da ação sobre a matéria; e os conhecimentos específicos.

Dessa forma, para se estudar as técnicas, conforme Van der Leeuw (1993), fazse necessário encará-las como "a arena de mediação entre o que é materialmente possível ou impossível e certos aspectos de organização social". Em adição, segundo Lemonnier (1980), as técnicas incluem conceitos, representações, símbolos e outros aspectos intelectuais, bem como a(s) organização(ões) envolvida(s). Mudanças nas técnicas estão diretamente ligadas a mudanças sociais, porque as duas existem em constante simbiose (VAN DER LEEUW, 1993).

Balfet (1991) afirma que as técnicas de fabricação de artefatos se dão por meio de um encadeamento de etapas obrigatórias que se iniciam na obtenção da matériaprima até as intervenções humanas nessa matéria para a constituição de um produto, ou seja, através de uma cadeia operatória.

Assim, pode-se inferir que para se pesquisar a cultura material de sítios arqueológicos de forma tridimensional, é preciso considerar as técnicas de manufatura de seus artefatos, e para isso, é fundamental a análise de sua cadeia operatória.

Na perspectiva de Balfet (1991), durante a etapa de manufatura, podem ocorrer situações inesperadas que podem levar a(o) artesã(o) a decidir novos métodos de 
forma consciente. Tal afirmativa é reiterada por Lemonnier (1992), que defende que a cadeia operatória é caracterizada por uma série de operações pré-estabelecidas mentalmente e novas escolhas tomadas durante o processo de manufatura do objeto, ou seja, não se trata de algo necessariamente linear, podendo sofrer mudanças através de momentos que se sucedem ou que se sobrepõem.

Diante disso, nota-se que ao pesquisar a cadeia operatória é importante encarar a (o) artesã (o) não como alguém que simplesmente reproduz as técnicas moldadas pelo grupo, mas um ser pensante que a todo o tempo toma decisões e põe em prática suas escolhas. As escolhas tecnológicas, segundo Lemonnier (1980), envolvem recursos como ferramentas utilizadas e conhecimentos técnicos, mas tratam-se também de processos de construção social.

Conforme Van der Leeuw (1993), muito mais importantes que os material disponíveis e as ferramentas, são as escolhas cruciais para se determinar a natureza, a forma dos produtos, no que será utilizado e por quanto tempo. Assim, tão importante quanto descrever como os objetos foram feitos é investigar o porquê de terem sido feitos de uma maneira e não de outra; como essas escolhas são feitas.

\subsection{HABITUS:}

O conceito "habitus" é derivado do conceito grego de hexis, descrito por Aristóteles em sua obra "Ética a Nicômaco"4. O Habitus foi apresentado pelo cientista social Pierre Bourdieu em sua obra "Esboço de uma teoria da prática" (1994a), como sendo o sistema de disposições duráveis e transferíveis, exigindo lógica e pensamento prático.

De acordo com Last (1995), Bourdieu concebeu tal conceito após realizar pesquisa etnográfica na Argélia nos anos 1960 e notar que as relações de parentesco não constituíam toda a gama de relações lógicas que uma análise estruturalista poderia explorar em relação às ações práticas, argumentando que tais práticas eram na verdade um sistema de estruturas estruturantes e disposições duráveis produzidas historicamente; o habitus.

\footnotetext{
${ }^{4} \mathrm{O}$ conceito hexis é descrito por Aristóteles como uma "disposição prática", permanente e costumeira, automática, e muito provavelmente desapercebida, pertencente a um plano ontogenético.
} 
Conforme observado por Preucel e Mrozowski (2010), Bourdieu dedicava-se a entender a relação entre estruturas sociais e prática individual. O habitus acaba então por expandir a noção de estrutura por incluir muitas formas de capital através do qual pode ser reproduzida e perpetuada. Dentre essas formas, destaca-se o capital cultural, que conforme Bourdieu (1977), incorpora práticas materiais.

Essas práticas materiais e o capital cultural constituem o que o autor define como doxa (do grego ठокعĩv - dokein - "crença comum"), ou seja, a adesão de práticas em grande parte comuns. De acordo com Preucel e Mrozowski (2010), esse doxa então, apresenta-se através do espaço na forma de paisagens e/ou cultura material, e, consequentemente, auxiliam os arqueólogos na construção da alusão entre "resíduos da vida diária e estruturas contextuais que trazem significado à vida".

É através das práticas diárias que as pessoas se organizam e dão sentido às suas vidas, e essas práticas e a organização espacial são foco da Arqueologia. Lightfoot et al (2010) observam que é através dessa rotina que muita da cultura material que recobre o registro arqueológico é produzida; as pessoas repetidamente expõem e reproduzem seus princípios estruturais e sistemas de crenças ao ordenar suas vidas diárias.

De acordo com Bourdieu (1994b), o habitus é inconsciente, incapaz de ser reduzido a um conjunto de regras; é uma competência linguística e cultural, cujas práticas gerais produzem modelos regulares de comportamento, mas com poucas normas e regras rígidas, o que confere instabilidade. Ele é a interação entre o inconsciente e o meio físico que é apreendido e reforçado através dessa interação (SHACKEL, 2010). O habitus pode ser transmitido no espaço de tempo de uma geração a outra, desempenhando um papel importante na ação social, se transformando através dessas ações; e na cultura material ele se manifesta.

Conforme Lightfoot et al (2010), a cultura material é responsável por um importante papel na criação e manifestação de identidades sociais, variando conforme os materiais são empregados na vida diária. Como exemplo disso, pode-se inferir sobre as relações sociais de pessoas e identidade de uma comunidade extinta através do modo de preparo dos alimentos e cuidados com o espaço habitacional.

Como no próprio título da obra, Bourdieu sugere que se desenvolva uma teoria da prática, ou seja, que se atente às diferenças existentes entre observação, interpretação e participação. 
Desta forma, em Arqueologia Brasileira, a aplicação de tal conceito é fundamental para se tentar entender como se deu o modo de transmissão de conhecimento das técnicas de manufatura dos elementos de cultura material realizada por povos préhistóricos, e em consequência disso, unir mais um importante fator que poderia esclarecer como era seu modo de vida. 
Capítulo 2

\section{Paisagem e contexto ambiental do sítio Limeira}

Para realizar o estudo da paisagem do sítio Limeira e analisar o seu contexto ambiental, foi necessário primeiramente caracterizar a paisagem do litoral do Espírito Santo, principalmente da região do município de Guarapari, onde o mesmo está localizado.

Este levantamento teve como base os pressupostos de Morais $(2011 ; 2012)$, nos quais o autor ressalta a importância do uso de elementos da Geografia, Geologia, Geomorfologia, etc. como ferramentas de auxílio para a interpretação dos dados arqueológicos.

Dessa forma, através de pesquisas bibliográficas e cartográficas, foram reunidos dados geológicos, geomorfológicos, pedológicos, hidrográficos e climáticos do litoral do Espírito Santo, além de informações sobre fauna e flora, sempre buscando relacioná-los ao ambiente na qual está inserido o sítio Limeira.

Também foram expostos neste capítulo as características paleoambientais, agrupadas a partir de referências bibliográficas cujos principais autores utilizados foram: Suguio (2003; 2005; 2010), Fairchild et al. (2009), Pessenda et al. (2012) e Martin et al. (1997), com a realização da caracterização do Período Quaternário do Brasil, com foco no Holoceno por motivos cronológicos, além de levantamentos sobre o paleoambiente do Espírito Santo com títulos de Buso Jr. (2014) e Pessenda (2012).

A combinação dessas informações em conjunto com o resultado de datação obtido para o sítio Limeira, torna possível uma breve descrição de como poderia ser o ambiente no qual o mesmo estava inserido à sua época de ocupação. 


\subsection{INSERÇÃO AMBIENTAL:}

\subsubsection{Geologia e geomorfologia:}

O levantamento dos aspectos geológicos e geomorfológicos em face aos artefatos líticos inseridos no sítio é de fundamental importância para se inferir o modus operandi da sociedade pretérita local (KNEIP e PALLESTRINI, 1990). Sua importância é ressaltada pelo fato de umas das principais fontes de matéria-prima utilizas pelos membros de grupos pré-históricos serem os afloramentos rochosos e seixos encontrados na beira de rios e praias (PROUS 1986/1990; MORAIS, 2007).

Assim, fez-se um estudo das características geológicas e geomorfológicas gerais do litoral do Espírito Santo, buscando enfoque na área de estudo, ou seja, no município de Guarapari.

De acordo com Patchineelam (2004), a plataforma continental brasileira apresenta cerca de $6400 \mathrm{~km}$ de extensão e largura entre $10 \mathrm{~km}$ (BA) e $300 \mathrm{~km}$ (AM), enquanto, segundo Martin e colaboradores (1996), na região do Estado do Espírito Santo a plataforma continental possui largura média de $230 \mathrm{~km}$.

Ab'Saber (2006) descreve a geomorfologia do litoral do Espírito Santo dividindo-o em 3 setores desde o norte ao sul do Estado:

- Delta do Rio Doce e Planície Costeira alargada regional - "retroterra marcada por uma linha de costa interiorizada, bem marcada." Possui pequenas lagoas costeiras, isoladas em restingas e na base interior da linha de costa, incluindo notáveis lagoas de terra firme, perpendiculares à margem esquerda do baixo Rio Doce.

- Litoral de Vitória - caracterizado por ser uma interrupção brusca do litoral em forma retilínea ao sul do Delta do rio Doce. Vitória é uma ilha do Espírito Santo, semi-isolada por manguezais interiores e inserida entre costões rochosos (Penedo) e morros arredondados.

- Litoral Sul Espírito-santense - possui tabuleiros embutidos que se transformam em planície, e estreita faixa de restingas. Possui vales de pequenos rios provenientes da Serra do Mar e seus largos esporões.

Conforme Martin e colaboradores (1996), a plataforma continental do Espírito Santo possui três unidades geomorfológicas distintas: 
- Embasamento Cristalino Pré-Cambriano

- Tabuleiro de Formação Barreiras

- Planície Costeira do Quaternário

De acordo com os autores, a planície costeira ${ }^{5}$ na qual o município de Guarapari está inserido, é caracterizada pela presença de afloramentos rochosos cristalinos pré-cambrianos, ocorrendo conjuntamente com depósitos da Formação Barreiras em alguns trechos. Esta informação pode ser observada no mapa geológico contido no anexo A desta Dissertação.

Como Formação Barreiras costumam ser designados os sedimentos de origem continental, pouco consolidados que estão dispostos em estreita faixa ao longo da área costeira, desde o Estado do Rio de Janeiro até o Pará, invadindo ainda o vale do Amazonas (ALBINO, 2001) depositados sobre a plataforma continental no período Terciário, ou seja, quando o nível do mar situava-se abaixo do atual (BIGARELLA, 1975).

No Espírito Santo, a Formação Barreiras é a formação geológica mais marcante, e se localiza paralelamente à zona costeira, abrangendo desde o sul até o extremo norte do Estado, com ocorrência desde o município de Marataízes a Guarapari e constituindo pequenas bacias isoladas na região Vitória-Cariacica (AMADOR, 1982). A disposição da Formação Barreiras ao longo do litoral do Espírito Santo pode ser observada no mapa 2.1.

De acordo com Martin et al (1997), no trecho entre Vitória-ES e o limite norte da planície costeira do rio Paraíba do Sul, a presença de falésias esculpidas em sedimentos da Formação Barreiras e/ou de rochas pré-cambrianas intemperizadas é a maior responsável pelas altas concentrações de minerais pesados encontradas nas areias daquela região. Além disso, é característica dos sedimentos arenosos do Holoceno a presença de fragmentos de conchas.

\footnotetext{
${ }^{5}$ As planícies costeiras ou litorâneas são regiões planas formadas por sedimentos terciários ou quaternários, depositados na zona costeira, ocorrendo ao longo da costa brasileira. A gênese desse ambiente está relacionada a um conjunto variado de fatores, que podem ser as variações do nível do mar do quaternário associadas às correntes de deriva litorânea, às fontes primárias de sedimento e às armadilhas para retenção do sedimento. Frequentemente tais planícies estão associadas a desembocaduras de grandes rios e/ou reentrâncias na linha de costa, e podem estar intercaladas por falésias e costões rochosos de idade pré-cambriana (AB'SABER, 2003).
} 


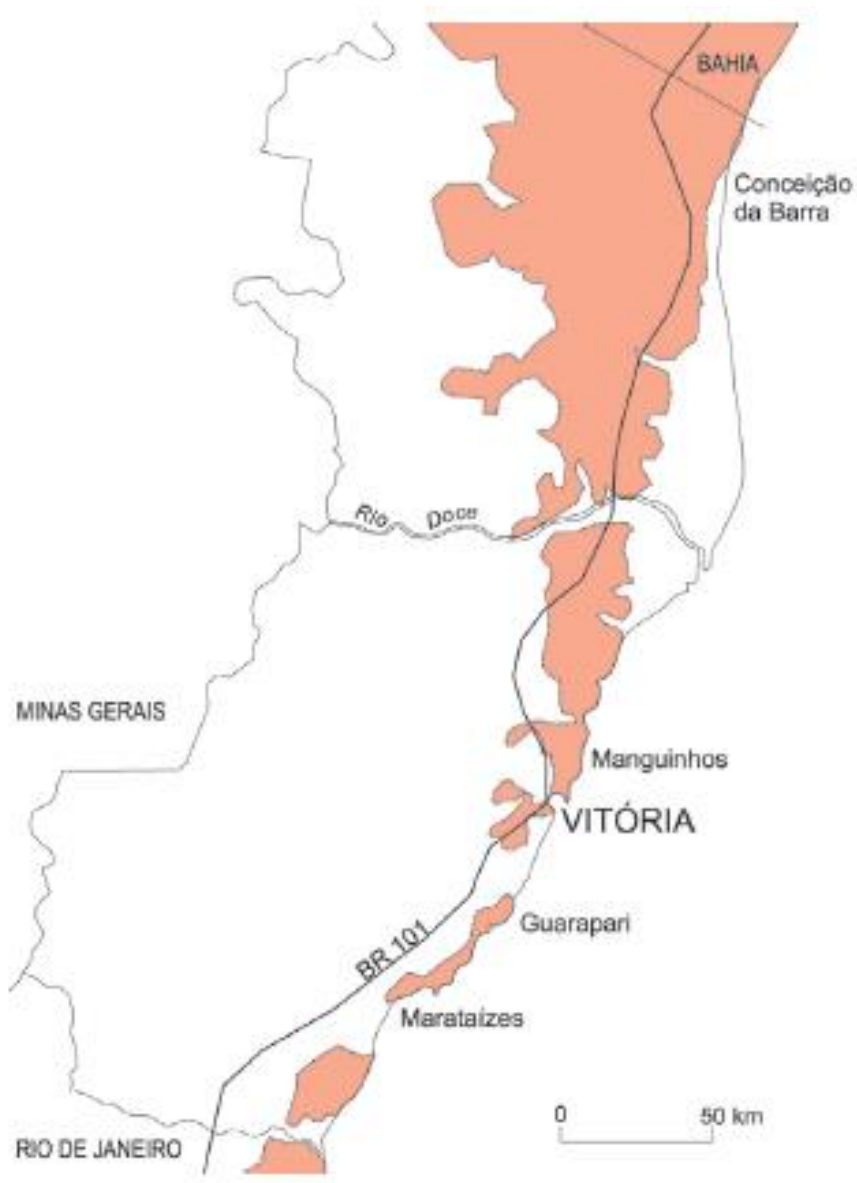

Mapa 2.1: Formação Barreiras ao longo do litoral do Espírito Santo. Fonte: Amador, 1982.

Essa constatação foi evidenciada por Franklin (2006), cuja pesquisa sobre a dinâmica do sedimento praial, em especial dos minerais pesados, na Praia da Areia Preta em Guarapari-ES resultou, em uma de suas conclusões, na evidenciação da origem da altíssima concentração desses minerais (uma das maiores do mundo em monazita) nas falésias que circundam parte da praia, ficando os mesmos concentrados em camadas, enquanto os grãos de quartzo são carreados pelas correntes de deriva litorânea.

O município de Guarapari está inserido na divisão litoral sul espírito-santense de Ab'Saber (2003), em uma região composta por rochas ígneas de alto grau, principalmente por gnaisses e granitos, sendo esses últimos mais recorrentes na zona costeira (SILVA et al. 2004). Em locais mais ao interior do continente o embasamento rochoso constitui elevações de até $600 \mathrm{~m}$, e na faixa litorânea apresenta-se na forma de numerosos afloramentos com altitudes médias a baixas, 
recortando a costa em praias de bolso, como as praias da Areia Preta, Castanheiras, Praia do Morro, Namorados, Virtudes e várias outras (SILVA et al. 2004).

Ainda na zona costeira, apresentam-se argilitos, arenitos e conglomerados avermelhados a esbranquiçados da Formação Barreiras na forma de "tabuleiros" (ARAl, 2006). Essas formações são bastante visíveis em pontos isolados da costa, como na praia da Areia Preta (NASCIMENTO, 2004; FRANKLIN, 2006).

No município de Guarapari, a Formação Barreiras extende-se por vários quilômetros e possui centenas de metros de largura, com orientação perpendicular ao mar.

De acordo com Nascimento e colaboradores (2011), o fundo dos vales decorrentes da presença da Formação Barreiras apresenta-se inundado por lagos remanescentes de antigas lagunas (como o lago Nova Guarapari e a lagoa Maimbá localizados ao sul do município) ou drenados por cursos d'água de pequeno porte, como os rios Jabaquara (porção central) e Uma (ao norte). Nesses locais desenvolve-se vegetação pantanosa, favorecendo a deposição de sedimento lamoso e turfas (ANEXO A).

Conforme Nascimento e colaboradores (2011), próximo à desembocadura de pequenos rios da região há um sistema de barreiras arenosas atribuídas ao desenvolvimento de linhas de costa recentes (holocênicas) e antigas (pleistocênicas) (praias e paleopraias) que isolam vales da Formação Barreiras e outras depressões paleolagunares da região de mar aberto (p. e. a região à retaguarda do Parque Estadual Paulo César Vinha, uma reserva de Mata Atlântica localizada a $19 \mathrm{~km}$ ao norte do sítio Limeira). Essas observações podem ser verificadas no Anexo $A$.

$\mathrm{Na}$ região onde se localiza o sítio Limeira, a Baía de Guarapari, há grande interação entre a água doce das drenagens da bacia hidrográfica Guarapari com a água salgada do mar, desenvolvendo-se planícies intermarés com vegetação de mangue. Além disso, o sítio Limeira encontra-se sobre um terraço arenoso holocênico, com ponto mais elevado a 2 metros do atual nível médio do mar e a 10 metros do nível máximo de maré, entre uma elevação com solos terciários da Formação Barreiras. As formações rochosas da área de entorno incluem principalmente rochas ígneas do tipo gnaisse e granito, que comumente apresentam veios de quartzo em sua superfície. 


\subsubsection{Pedologia:}

Os solos da região onde se insere o sítio Limeira são produto do intemperismo de rochas cristalinas, predominantemente do tipo granito e gnaisse, conforme já observado. Essas rochas são classificadas como rochas sedimentares ígneas terciárias da Formação Barreiras, além de terem origem em sedimentos quaternários fluviais e/ou de origem marinha (SUGUIO, 2003).

Conforme Suguio (2003), em geral, o intemperismo das rochas cristalinas graníticas gera solos de textura argilosa, o que justifica o fato de a região de Guarapari ser dominada pela cobertura por solo podzólico amarelo (ANEXO B), caracterizados por conterem argila e serem bem a moderadamente drenados.

Esses solos apresentam cores amareladas, possuem boas condições físicas para o desenvolvimento das plantas e um relevo plano, suavemente ondulado. Sua principal limitação é a baixa fertilidade natural (RADAM BRASIL, 1983).

Por localizar-se em área adjacente ao manguezal, o sítio Limeira apresenta em sua camada superficial solo arenoso, rico em matéria orgânica, porém, através da realização de perfil estratigráfico foi possível identificar solo areno-argiloso de cor amarelada em sua estrutura, o que confirma sua inserção sobre solo podzólico amarelo.

Em adição, conforme observado anteriormente, o litoral de Guarapari é bastante recortado, apresentando trechos propícios para a retenção de sedimentos que formam promontórios e ilhas próximas ao continente. Além disso, o clima da região favorece a produção de material bioclástico autóctone (ALBINO, 1999) e segundo Cetto (2005), a batimetria da região não apresenta, de forma geral, aclives ou declives acentuados; ou seja, essa porção da plataforma continental possui topografia suave, o que acarreta maior estabilidade no transporte de sedimentos litorâneos para a região off shore e vice-versa.

\subsubsection{Hidrografia e hidrologia:}

Em nível regional, o Espírito Santo possui 12 bacias hidrográficas; cinco delas são de domínio da União, e as demais são estaduais, ou seja, todos os seus limites estão dentro do domínio capixaba. Dentre estas ultimas, destaca-se a bacia 
hidrográfica Guarapari, que abrange parte da região dos municípios Guarapari e Vila Velha e possui como principais cursos d'água os rios Jabuti, Perocão e Una, além do rio Aldeia Velha e o córrego Lameirão, que afluem diretamente para a baía de Guarapari (Anexo C).

Conforme informações contidas no site do Instituto Estadual do Meio Ambiente do Espírito Santo (IEMA) , a bacia hidrográfica Guarapari possui área de drenagem total de $321 \mathrm{~km}^{2}$, apresenta baixos índices de precipitação pluviométrica com média anual em cerca de 1340 e $1380 \mathrm{~mm}$ em sua parte mais continental e 1170 e $1200 \mathrm{~mm}$ na faixa litorânea. Em algumas áreas ocorrem até mesmo conflitos decorrentes da baixa disponibilidade hídrica na bacia. Isso se dá devido à grande demanda por água principalmente durante o período do verão, quando a chegada de turistas aumenta substancialmente o número de habitantes na região.

Observando o mapa contido no anexo $\mathrm{D}$, percebe-se que dentre os cursos d'água da bacia hidrográfica Guarapari destaca-se os rios Jabuti, Conceição e Aldeia Velha, pois estes seguem por regiões próximas ao sítio arqueológico Limeira. O rio Jabuti alimenta a Baía de Guarapari, que recebe grande parte da carga de esgoto in natura da região (Praia do Morro, região central e bairros adjacentes), apesar de sua importância extrativista e turística. A cobertura do tratamento de esgoto no município de Guarapari é de 30\% (SMMA, 2007).

\subsubsection{Clima e oceanografia:}

Os dois principais domínios climáticos do Espírito Santo são o mesotérmico úmido, que ocorre na região montanhosa, e o tropical chuvoso, nas terras baixas (MENDONÇA \& DANNI-OLIVEIRA, 2007).

O clima tropical chuvoso caracteriza-se por possuir temperaturas elevadas durante todo o ano, com médias térmicas superiores a 22ํㅡ (MENDONÇA \& DANNIOLIVEIRA, 2007). Em Guarapari, conforme o Instituto Nacional de Meteorologia (INMET, 2012), as temperaturas atmosféricas variam entre 21 e $27^{\circ} \mathrm{C}$ e a precipitação média varia entre 1300 a $1400 \mathrm{~mm}$ ao ano. Esses dados podem ser observados no gráfico 2.1.

\footnotetext{
${ }^{6}$ http://www.meioambiente.es.gov.br/
} 
Gráfico 2.1: Média anual de temperatura e de precipitação em Guarapari-ES.

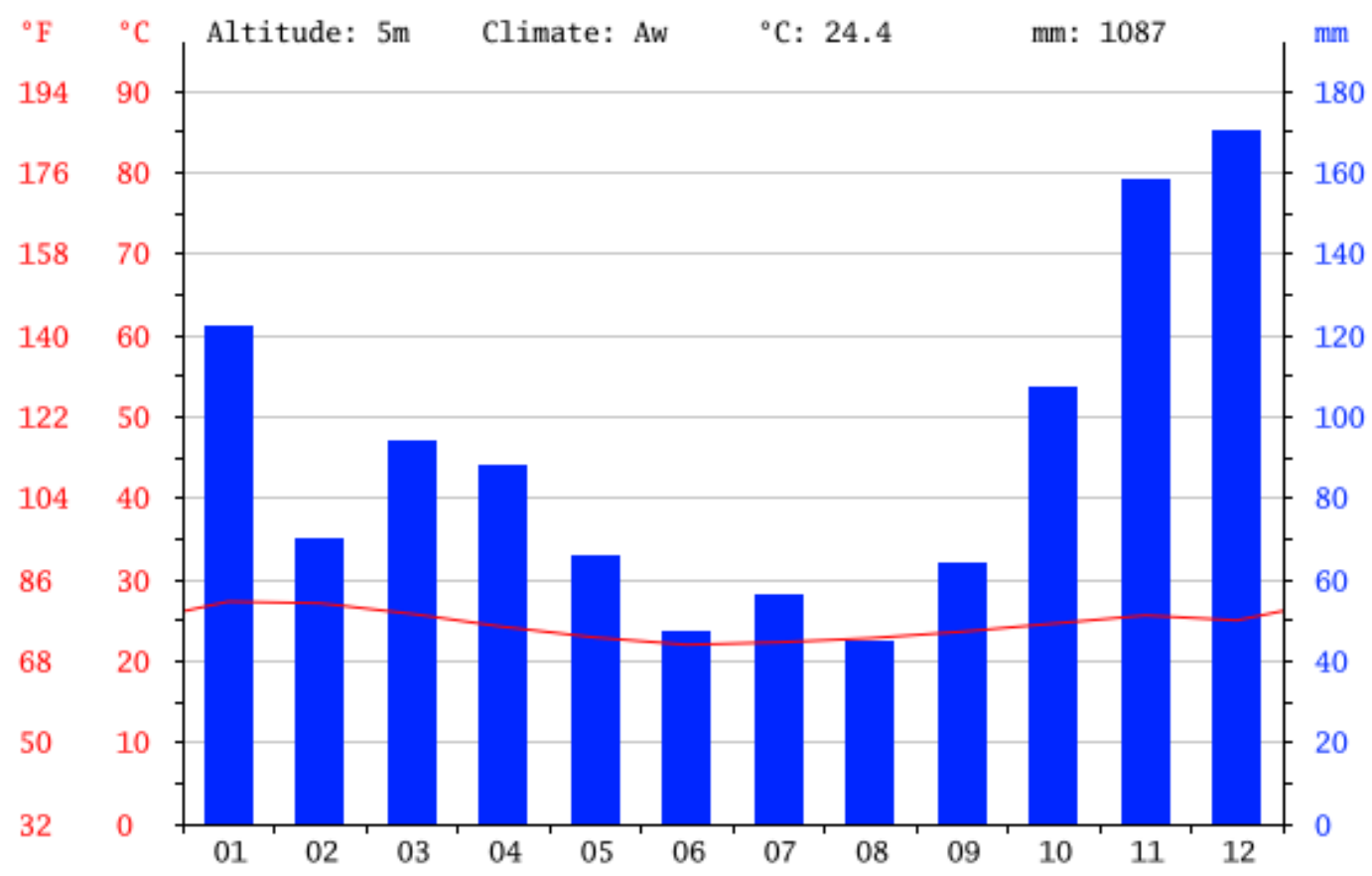

Fonte: INMET (2012).

De acordo com Nimer (1989), a região de Guarapari encontra-se sob a influência do centro de alta pressão do Atlântico Sul, o que determina um padrão de circulação dos ventos de nordeste (NE) junto à costa na maior parte do ano, ou seja, durante os meses de outubro a março, período em que ocorrem maiores precipitações. Já entre os meses entre abril e setembro, conforme Albino et al. (2005), os ventos predominantes originam-se nos quadrantes sudeste (SE) e sul (S).

Quanto aos sistemas de correntes marinhas, o Espírito Santo é influenciado principalmente pelo Sistema Tropical Atlântico (Ta) e pelo Sistema Polar Atlântico (Pa). O sistema Ta é o principal, originado no Atlântico Sul, atuando constantemente durante todo 0 ano. A região sudeste frequentemente recebe influência desse sistema através das correntes de nordeste seguidas pelas correntes de leste. Por outro lado, durante o inverno, a região sudeste recebe notada influência do sistema $\mathrm{Pa}$. Esse sistema atua principalmente na região sul, mas com a presença dos ventos S e SE durante esse período do ano, consegue atingir também a região sudeste (ALBINO, 2001) (Mapa 2.2). 


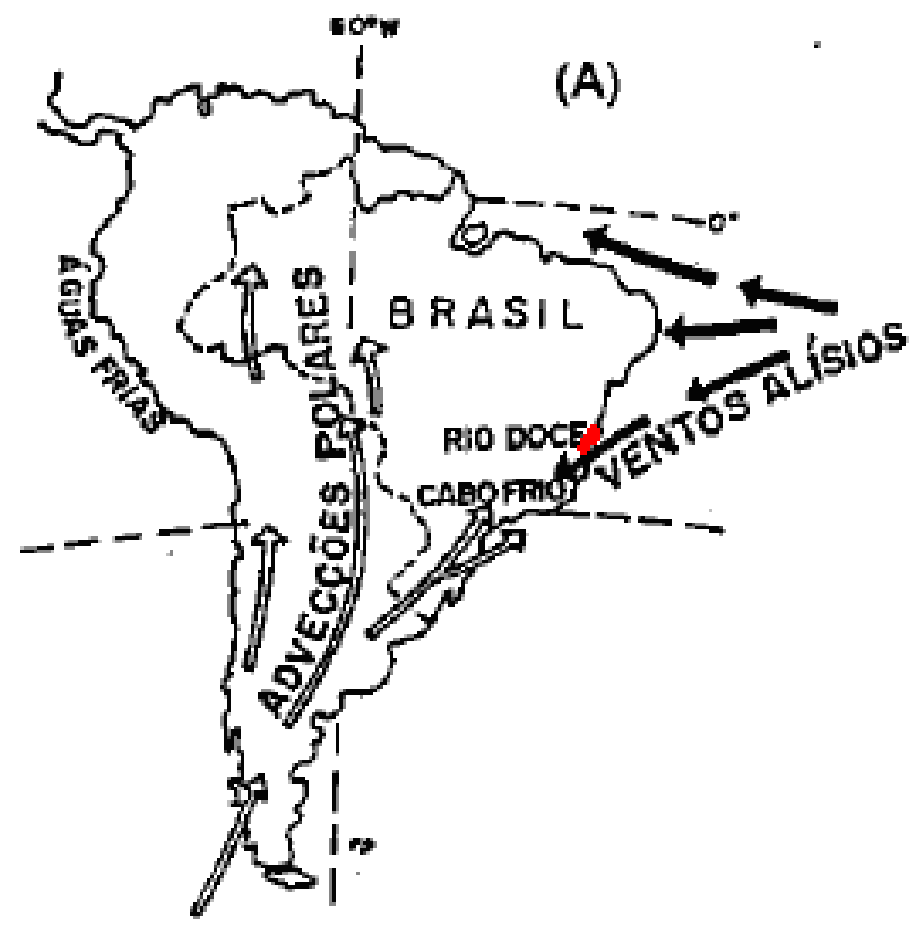

Mapa 2.2: Regime de ventos no Brasil em condições normais. Em destaque, o Estado Espírito Santo. Adaptado MARTIN et al, 1997

De acordo com dados da Diretoria de Hidrografia e Navegação (DHN), a área onde se encontra o sítio Limeira apresenta micromaré semidiurna, com ondas que podem atingir quase $2 \mathrm{~m}$ durante as marés altas em sizígias.

\subsubsection{Cobertura vegetal:}

Os estudos sobre a cobertura vegetal do Estado do Espírito Santo são esparsos, tendo seu início em através das pesquisas desenvolvidas por Ruschi em 1950 e por Azevedo em 19627. Sabe-se que este possui como vegetação original a de Mata Atlântica. Porém, desde o período do contato com os portugueses no século XVI aos dias de hoje, esse bioma foi devastado em cerca de $95 \%$ de seu território (PIMENTEL \& SILVA, 2011).

\footnotetext{
${ }^{7}$ Ruschi A (1950) Fitogeografia do Estado do Espírito Santo. Boletim do Museu de Biologia Prof. Mello Leitão 1: 1-353.

Azevedo LG (1962) Tipos de vegetação do estado do Espírito Santo. Revista

Brasileira de Geografia 24, 111-115.
} 
De acordo com Martin e Suguio (1987) 100\% do território do Espírito Santo era ocupado por Mata Atlântica na forma de florestas, falésias, manguezais, baías, estuários, restingas, etc. Atualmente uma pequena parte desse bioma é conservado na forma de 17 Unidades de Conservação (UC) totalizando 56 mil hectares, o que representa cerca de $1,23 \%$ do território original. Ainda assim, o Espírito Santo abriga hoje a maior área de Mata Atlântica do Brasil.

Na região litorânea do Espírito Santo ocorrem duas zonas fisiográficas distintas: a zona conhecida como litoral oriental, que compreende a área desde o recôncavo baiano até o sul do Estado, e o litoral do Sudeste, que se estende desde o sul do Espírito Santo até o Cabo de Santa Marta em Santa Catarina (SUGUIO \& TESSLER, 1984; MARTIN \& SUGUIO, 1987; VILLWOCK et al., 2005).

Os primeiros levantamentos sobre a vegetação em Guarapari foram publicados por Pereira em $1990^{8}$, cuja pesquisa descreveu a restinga de Setiba, ao norte da cidade, com informações sobre suas diferentes formações vegetais e fitofisionomia (PIMENTEL \& SILVA, 2011). Por ser uma cidade litorânea, mas também possuir região montanhosa, Guarapari apresenta quase todos os padrões de vegetação dos ambientes pertencentes ao bioma Mata Atlântica. Dessa forma, a área que inclui o local do sítio Limeira a vegetação predominante é de restinga e manguezal, merecendo que sejam destacadas.

As características de vegetação essenciais dos ambientes de restinga e manguezal estão expostas no quadro a seguir:

Quadro 2.1: Características de vegetação dos ecossistemas restinga e manguezal.

\begin{tabular}{|l|l|l|}
\hline \multicolumn{2}{|c|}{ Restinga } & \multicolumn{3}{|c|}{ Manguezal } \\
\hline $\begin{array}{l}\text { Sedimento arenoso de origem marinha e } \\
\text { flúvio-marinha; }\end{array}$ & $\begin{array}{l}\text { Sedimento lodoso, rico em matéria } \\
\text { orgânica; }\end{array}$ \\
\hline $\begin{array}{l}\text { Vegetação herbácea (Ex.: Turnera } \\
\text { ulmifolia ou Flor-do-Guarujá), arbustiva } \\
\text { (Ex.: Lantana camara ou camará, Clusia } \\
\text { fluminensis ou Clúsia além de Cereus } \\
\text { sp. ou cactos) e arbórea (Ex.: Protium } \\
\text { heptaphyllum e Pouteria coelomatica); }\end{array}$ & $\begin{array}{l}\text { (mangue vermelho), Laguncularia } \\
\text { racemosa (mangue branco), Avicenia sp } \\
\text { (mangue de botão); }\end{array}$ \\
\hline
\end{tabular}

\footnotetext{
${ }^{8}$ Pereira OJ (1990) Caracterização fitofisionômica da restinga de Setiba/Guarapari-ES. In: ACIESP (org.). II Simpósio de ecossistemas da costa sul e sudeste brasileira: estrutura, função e manejo 3 : 207-219.
} 
Cont. Quadro 2,1.

\begin{tabular}{|l|l|}
\hline \multicolumn{2}{|c|}{ Restinga } \\
\hline $\begin{array}{l}\text { Podem ou não sofrer inundações } \\
\text { marinhas durante o ano; }\end{array}$ & $\begin{array}{l}\text { Sofrem inundações marinhas diárias de } \\
\text { acordo com o sistema de marés; }\end{array}$ \\
\hline $\begin{array}{l}\text { Devido à possível exposição a variações } \\
\text { de salinidade, excesso de incidência de } \\
\text { raios solares, escassez de água, etc., é } \\
\text { considerado um ambiente frágil. }\end{array}$ & $\begin{array}{l}\text { Devido à variação de salinidade, escassez } \\
\text { de oxigênio devido à alta concentração de } \\
\text { matéria orgânica, é considerado um } \\
\text { ambiente frágil. }\end{array}$ \\
\hline
\end{tabular}

A poucos metros do local onde se insere o sítio Limeira há a margem da Baía de Guarapari, onde encontra-se o manguezal, apresentando vegetação composta por Rhizophora mangle com suas raízes aéreas (rizóforos) e lenticelas, para sustentação e para a respiração e equilíbrio de salinidade respectivamente, já que o solo lodoso impede a fixação da planta e a alta concentração de matéria orgânica faz com que o ambiente seja pouco oxigenado.

Em seguida, em direção ao continente e em solo mais arenoso, as Rhizophora mangle são substituídas pelas Avicenia $s p$, cujas raízes apresentam geotropismo negativo e pneumatóforos, ou seja, apontam para a área externa do solo e também possuem adaptações para a garantia de oxigenação.

Devido ao fato de o manguezal nessa região ser pouco amplo, logo em seguida se apresenta a vegetação típica de restinga, com arbustos e árvores baixas. Essa vegetação descrita é a que circunda a área do sítio atualmente.

É importante ressaltar que o sítio Limeira está inserido em zona urbana, fazendo com que essa área inevitavelmente sofra ações antrópicas. Dessa forma, apesar de o manguezal não estar muito impactado, a vegetação da restinga sofreu (e sofre) com a inserção de espécimes exóticos, podendo-se destacar a brachiaria, espécie nativa da África, introduzida no Brasil como forrageira e que se transformou em espécie invasora de vários ecossistemas, prejudicando-os através do impedimento do desenvolvimento de gramíneas nativas; o que também ocorreu no caso da restinga onde se insere o sítio Limeira.

A seguir é apresentada uma seção esquemática do sítio arqueológico Limeira em relação ao seu substrato geológico local: 


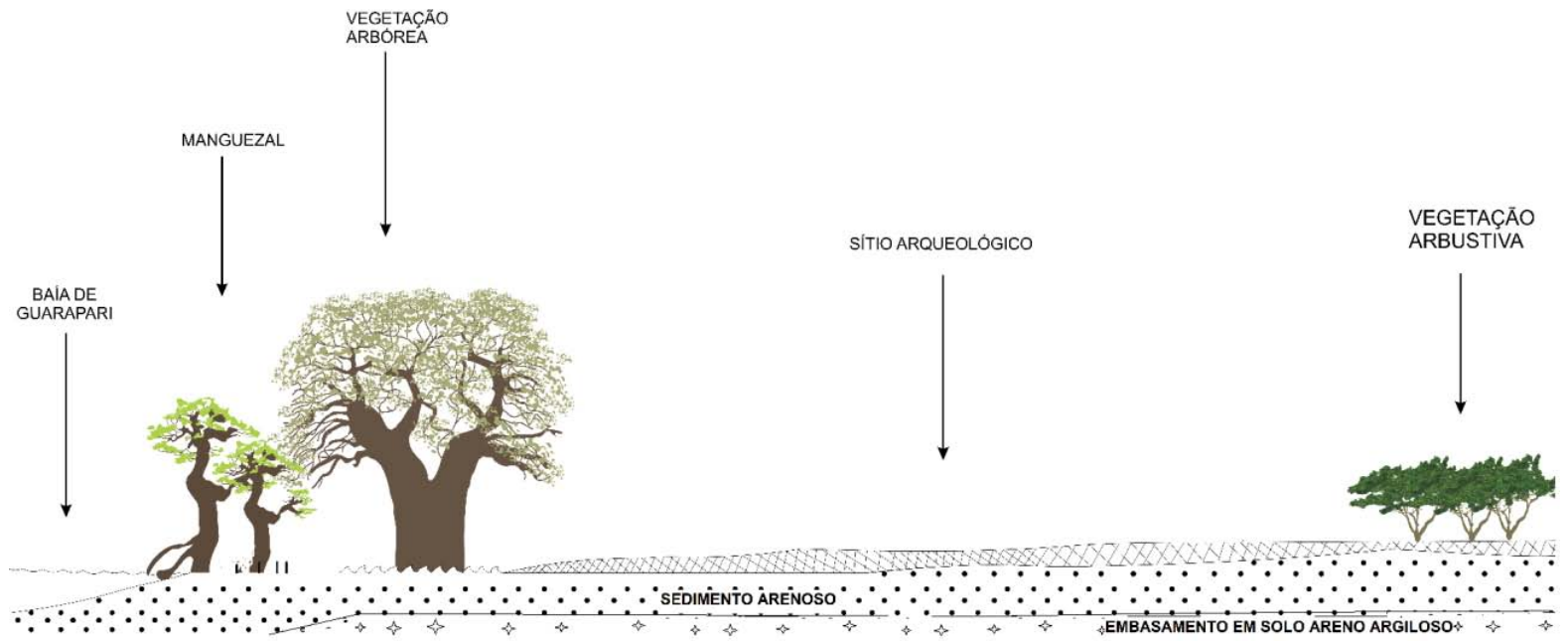

Fig. 2.1: Seção esquemática do sítio arqueológico Limeira em relação ao seu substrato geológico local (sem escala). Desenho: Maria Ester Franklin e Mariana Franklim.

\subsubsection{Fauna:}

Conforme citado anteriormente, o sítio Limeira encontra-se em uma região influenciada diretamente pelos ecossistemas manguezal e restinga. Tais ecossistemas são caracterizados por possuírem uma fauna diversa, porém específica. O quadro abaixo apresenta as características essenciais faunísticas desses ambientes (PIMENTEL \& SILVA, 2011):

Quadro 2.2: Características faunísticas dos ecossistemas restinga e manguezal.

\begin{tabular}{|l|l|l|}
\hline \multicolumn{2}{|c|}{ Restinga } & \multicolumn{3}{|c|}{ Manguezal } \\
\hline $\begin{array}{l}\text { Fauna diversificada variando conforme } \\
\text { as características florísticas, que }\end{array}$ & $\begin{array}{l}\text { Constituída principalmente por peixes, } \\
\text { moluscos e crustáceos, podendo } \\
\text { promovem um ambiente com maior ou } \\
\text { menor incidência de sombra, } \\
\text { disponibilidade de alimentos, etc.; }\end{array}$ & $\begin{array}{l}\text { apresentar até mesmo répteis (cobra, } \\
\text { tartaruga, lagartos, etc.) mamíferos } \\
\text { (Ariranha, Mão-pelada, etc.) e aves } \\
\text { marinhas (Corelheiro, Martim Pescador, } \\
\text { Guará, etc.), que usam o manguezal como } \\
\text { refúgio, com ambiente para a reprodução } \\
\text { ou alimentação; }\end{array}$ \\
\hline
\end{tabular}




\begin{tabular}{|c|c|}
\hline Restinga & Manguezal \\
\hline $\begin{array}{l}\text { Apresenta aves (Beija-flor, Bem-te-vi, } \\
\text { Anú Preto, corujas, etc.), répteis } \\
\text { (calangos, lagartos, cobras, etc.), } \\
\text { pequenos mamíferos (Saruê ou Gambá- } \\
\text { de-orelha-preta, Caxinguelê) e insetos; }\end{array}$ & $\begin{array}{l}\text { Muitos animais habitam os manguezais } \\
\text { durante certo período de sua vida, como } \\
\text { os camarões e algumas espécies de } \\
\text { peixes (Lambari, Robalo, Garoupa, etc.), } \\
\text { que passam sua fase larval nesse } \\
\text { ambiente ou o frequentam para } \\
\text { reprodução e/ou alimentação; }\end{array}$ \\
\hline $\begin{array}{l}\text { A fauna da restinga, em sua maioria, é } \\
\text { permanente, ou seja, os animais } \\
\text { habitam o ambiente por toda a sua vida. } \\
\text { Porém, aves migratórias também } \\
\text { povoam a restinga, assim como outras } \\
\text { espécies que a habitam em busca de } \\
\text { alimentos, abrigo, etc.; }\end{array}$ & $\begin{array}{l}\text { Alguns animais sésseis permanecem } \\
\text { durante toda a vida no manguezal, como } \\
\text { Perna perna (sururu) e Crassostrea } \\
\text { rhizophora (ostra de mangue); }\end{array}$ \\
\hline $\begin{array}{l}\text { Por ser um ambiente de transição, a sua } \\
\text { fauna é considerada frágil. }\end{array}$ & $\begin{array}{l}\text { Caranguejos habitam o solo do } \\
\text { manguezal, onde escavam galerias e } \\
\text { aproveitam a matéria orgânica dissolvida } \\
\text { além de folhas, restos de animais, etc. } \\
\text { para a alimentação. As principais espécies } \\
\text { são Aratu (Aratus pisonii), Guaiamu } \\
\text { (Cardisoma guanhumi), Uçá (Ucides } \\
\text { cordatus) e Chama-maré (Uca sp.). }\end{array}$ \\
\hline
\end{tabular}

Em relação ao sítio Limeira, a fauna do ecossistema manguezal apresenta principalmente o molusco Crassostrea rhizophora e os crustáceos Aratus pisonii, Cardisoma guanhumi, e Uca sp. Segundo relatos de moradores vizinhos a essa área e que utilizam-se do manguezal como meio de subsistência, o caranguejo Ucides cordatus também era recorrente, mas desapareceu nos últimos anos.

Esse fato vem ao encontro de resultados obtidos em literatura especializada, na qual indica a redução populacional dessa espécie em decorrência da "doença do caranguejo letárgico" que está se espalhando ao longo da costa brasileira (SANCHES \& FERREIRA, 2010). 
Quanto à restinga, de acordo com o que foi observado durante as etapas de pesquisas intensivas de campo no sítio Limeira, devido a ações antrópicas sua fauna ficou reduzida a lagartos e cobras, além de pequenos pássaros. A introdução de espécies vegetais exóticas, como a já citada brachiaria, reduziu sua flora, certamente resultando na evasão de espécimes animais.

Em adição, a população circunvizinha se dispõe da área na qual se insere o sítio Limeira para abrigo de animais domésticos como cavalos e cabras que se utilizam da vegetação local como fonte de alimento.

\subsection{PALEOAMBIENTE DO LITORAL DO ESPÍRITO SANTO:}

A paisagem que pode ser observada hoje é fruto de atividades antrópicas que atravessaram milênios. Desde o surgimento do Homem o ambiente tem sofrido sua influência. Dessa forma, estudos pautados em reconstituições paleoambientais (clima e vegetação) podem ser uma importante ferramenta para a Arqueologia. Conhecimentos mais detalhados sobre o ambiente pretérito aliados a dados concernentes aos vestígios arqueológicos possibilitam a ampliação de interpretações sobre modo de vida, padrões de subsistência e interação com o ambiente por parte das populações que habitavam os assentamentos pré-históricos.

Neste sentido, para essa Dissertação foram reunidos dados a respeito do paleoambiente do litoral do Espírito Santo, com enfoque maior para a região onde se localiza o sítio Limeira.

Porém, para possibilitar uma visão mais holística, foi realizada uma breve caracterização do período Quaternário, destacando resumidamente como ocorreram as mudanças ambientais e paisagísticas nos últimos anos que constituíram essa época da história do planeta Terra, o Holoceno, com fulcro nas variações paleoambientais ocorridas no litoral brasileiro, destacando a região Sudeste, onde se localiza o sítio Limeira. Além disso, com o mesmo objetivo, também foi realizada uma breve caracterização dos sítios arqueológicos litorâneos da região Sudeste. 


\subsubsection{O período Quaternário - Holoceno:}

O termo Quaternário foi introduzido por Desnoyers ${ }^{9}$ em 1829 e refere-se ao período mais recente da história do planeta Terra (últimos 1.8 milhões de anos), marcado por grandes glaciações, pela megafauna típica de mamíferos e pelo surgimento do Homem (Suguio 2005).

Ao longo da existência da Terra (cerca de 4,6 bilhões de anos), muitas foram as mudanças ambientais que ocorreram, decorrentes de mecanismos astronômicos, atmosféricos, geológicos, etc. Mas a introdução do ser humano durante o período Quaternário representou a inserção de um novo agente de mudanças, cujo papel ao longo do tempo passou a ser atuante em todas as esferas do ambiente terrestre.

De acordo com Campos e Santos (2009), as glaciações, com suas extremas variações climáticas, repercutiram sobre todos os ambientes do planeta, causando modificações nas zonas climáticas da Terra, em função das mudanças nas circulações das massas de ar atmosféricas e de correntes oceânicas, havendo redistribuição nos regimes de precipitação atmosférica e na cobertura vegetal. Além disso, ocorreram regressões e transgressões marinhas ao longo dos continentes com variações do nível médio marinho (NMM) decorrentes de períodos glaciais e interglaciais, mudança na velocidade de rotação ou na intensidade do campo gravitacional terrestre devido à redistribuição dos continentes e deformação das rochas, comprimidas pelas extensas camadas de gelo durante as glaciações e soerguidas após o degelo, com o alívio de carga.

O território brasileiro abrange uma área superior a 8,5 milhões de quilômetros quadrados, correspondendo a 45\% da América do Sul (IBGE, 2012), ocupando parte da Plataforma Sul-Americana, composta predominantemente por rochas ígneas (de origem vulcânica, como o granito e o basalto) e metamórficas pré-cambrianas (formadas através de alterações físicas e/ou químicas sofridas por outras rochas, como o gnaisse, o quartzo e o quartzito), formando o núcleo cristalino do continente sul americano. No Brasil os depósitos quaternários estão associados às bacias hidrográficas, como a Amazônica, ou às planícies litorâneas (SUGUIO, 2005).

\footnotetext{
${ }^{9}$ DESNOYERS, J. Observations sur un ensemble de dépots marins plus récent que le terrain tertiaire du bassin de la Seine, et pouvant constituer une formation géologique distincte, precédée d'un aperçu sur la non-simultaneité des bassins tertiaires. Annales des Sciences Naturelles, v.16, p. 171-214 e 402-491, 1829.
} 
É importante lembrar que conforme exposto por Suguio (2003), como as glaciações quaternárias não atingiram o território brasileiro, não há no Brasil sedimentos glaciais ou periglaciais. Porém, de acordo com Albino (1999), a evolução geológica durante o Quaternário, com a variação do nível do mar ao longo da costa do Brasil, foi responsável pela alternância entre os processos continentais (deposicionais) e os processos marinhos (erosivos e deposicionais). Estas inversões deixaram marcas sobre a geomorfologia quaternária do litoral centro-sul do Espírito Santo, onde se observa a presença de falésias dos Tabuleiros da Formação Barreiras, planícies de cordões litorâneos, lagunas, depressões alagáveis intercordões e arenitos de praia.

O Holoceno teve início no final da última grande glaciação (Würm), há cerca de 10.000 anos, e é caracterizado principalmente pelo aparecimento do homem moderno e início de uma fase interglacial em nosso planeta, que dura até os dias de hoje (FAIRCHILD et al, 2009). Durante esse tempo, várias mudanças climáticas ocorreram (e ocorrem) no planeta, sendo este um dos fatores decisivos para que houvesse alterações nas linhas costeiras, ou seja, variações do nível médio marinho (SUGUIO, 2010).

A variação do nível médio marinho se dá devido a alterações na posição entre o mar e o continente, que podem ser decorrentes de variações no nível do oceano com modificação da bacia oceânica ocorridas com a movimentação de placas tectônicas, alteração no volume da água por esfriamento e aquecimento globais e/ou alterações oceanográficas e geofísicas na superfície dos oceanos (regime de marés, correntes marinhas, pressão interna do planeta, etc.) (SUGUIO et al, 1985).

Além disso, contribuem para variação no nível médio marinho alterações nos níveis continentais, através de movimentos tectônicos, que podem causar dobramentos, falhas e levantamentos na linha de costa, movimentos isostáticos, que provocam alterações na carga sobre o continente através do surgimento e desaparecimento de geleiras, erosão e acúmulo de material, e sedimentação costeira devido à deposição e retirada de material sedimentar decorrentes das próprias regressões e transgressões marinhas (CRUZ, 1998).

De acordo com Pessenda et al. (2012), dados levantados sobre a reconstituição do nível do mar na costa sudeste brasileira revelam que entre 7800 e 6600 anos AP houve a primeira transgressão marinha, que atingiu altura máxima em 5500 anos AP de 2 a $5 \mathrm{~m}$ abaixo da linha de costa do presente em idade calibrada. Ainda de acordo 
com esses autores, a partir dessa época teve início o recuo do nível do mar até os níveis encontrados hoje, apresentando ou não oscilações ao longo do tempo, decorrentes, por exemplo, de processos tectônicos. Porém, é importante ressaltar que, ainda de acordo com os autores, os dados dos últimos 2200 anos AP indicam que os ambientes estuarinos e lagunares eram totalmente similares aos do presente.

Em relação aos estudos paleoclimáticos, de acordo com Oliveira et al. (2005), poucas pesquisas descrevem o clima e a vegetação da região Sudeste durante o Holoceno, porém, ao que se indica atualmente, desde o início da época holocênica até aproximadamente 5500 anos AP, havia grandes áreas de cerrado, refletindo um clima mais seco, tendo os últimos 1000 anos como a época mais úmida na região.

No Rio de Janeiro, conforme Oliveira et al (2005), a transição do Pleistoceno para o Holoceno foi marcada por grande instabilidade climática e vegetacional, com uma fase inicialmente úmida, apresentando brejos, pântanos e solos encharcados, seguida de uma tentativa de cobertura vegetal, com vegetação de savana. Oscilações do NMM foram responsáveis pela formação de vários lagos e lagunas a cerca de 7000 anos AP. Em 5100 anos AP, o rebaixamento do NMM permitiu o desenvolvimento de uma floresta tropical semidecidual ${ }^{10}$ e floresta ombrófila ${ }^{11}$, e a partir daí, (4000 anos AP), houve uma fase mais seca e de altas temperaturas, alternando-se entre fases úmidas e secas nos anos subsequentes. O máximo de umidade foi atingido em 2540 anos AP, verificado pela constatação de abundância de esporos de pteridófitas e baixos valores de $\mathrm{O}^{18}$.

No Espírito Santo, de acordo com Martin et al (1997), entre as desembocaduras do Rio Doce (norte do Estado) e Paraíba do Sul (norte do RJ), após o rebaixamento do NMM as lagunas existentes sofreram ressecamento e foram substituídas por áreas pantanosas. Posteriormente, novas elevações do nível do mar (3900-3600 e 2800-2500 anos AP) promoveram a reocupação dessas lagunas, principalmente na foz do rio Doce, além da formação de lagunas de forma alongada em terraços

\footnotetext{
${ }^{10}$ Ambiente condicionado pela dupla estacionalidade climática (uma tropical, com época de intensas chuvas de verão seguidas por estiagens acentuadas; e outra subtropical, com período seco provocado pelo intenso frio de inverno, com temperaturas médias inferiores a $15^{\circ} \mathrm{C}$ ), é constituída por vegetação com gemas foliares protegidas da seca por escamas (catáfilos ou pelos), tendo folhas adultas esclerófilas (cujo tecido se assemelha ao couro). Em tal tipo de vegetação, a porcentagem das árvores caducifólias (que perdem as folhas em baixas temperaturas), no conjunto florestal e não das espécies que perdem as folhas individualmente, é de 20 e 50\% (Veloso et al.,1991).

11 Vegetação que ocorre ao longo dos cursos de água, ocupando os terraços antigos das planícies quaternárias. Tal formação é constituída por espécies vegetais com alturas variando de 5 a 50 metros, de rápido crescimento, em geral de casca lisa, tronco cônico e raízes tabulares (lateralmente achatadas) (Veloso et al.,1991).
} 
arenosos holocênicos durante os abaixamentos do NMM nas planícies costeiras dos rios Doce e Paraíba do Sul, o que explica a presença de lagoas como a Salgada, das Ostras, entre outras localizadas no cabo de São Tomé.

\subsubsection{Ocupação humana no litoral brasileiro durante o Holoceno:}

Conforme abordado anteriormente, o Holoceno foi marcado pelo advento do Homem moderno. Para a presente Dissertação, acredita-se que seja pertinente ao menos uma breve revisão sobre as características dos sítios arqueológicos litorâneos da região sudeste do Brasil, na qual se insere o sítio Limeira, para que seja possível obter-se uma visão diacrônica a respeito das características das ocupações humanas nesse local.

Assim, é importante destacar que ao longo do litoral sudeste do Brasil existem, além de sítios arqueológicos do tipo sambaqui marítimo ou acampamentos conchíferos, outros tipos de assentamentos, como esconderijos e sambaquis fluviais (PROUS, 1992). Neste item foi apresentada uma abordagem resumida desses tipos de sítios, já que os sambaquis marítimos e acampamentos conchíferos são abordados mais detalhadamente em outros itens deste capítulo.

Para isso, optou-se por adotar as definições elaboradas por André Prous (1992) conforme se segue:

- esconderijos - são sítios fora das imediações de ocupação humana, onde são encontrados enterrados a pouca profundidade objetos relacionados à cultura sambaquieira. Não apresentam nenhuma estrutura de superfície e geralmente apresentam pouco material arqueológico.

- sambaquis fluviais - são sambaquis construídos fora da faixa litorânea e de ambiente de manguezal, constituídos por conchas terrestres e dulçaquícolas, além de muitos restos de peixes, coquinhos e ossos de mamíferos terrestres. Apresentam em geral material lítico composto por machados semipolidos, alisadores e lascas com ou sem retoque, material feito de osso como furadores, pontas feitas de ossos de aves, anzóis e adornos de bula timpânica, entre outros. 


\section{Sambaquis marítimos:}

Sambaquis caracterizam-se por serem montes resultantes do acúmulo progressivo e intencional de conchas, areia ou terra (LIMA, 1991). De acordo com Prous (1992), esses sítios podem ser marítimos ou fluviais, e dentre os sítios litorâneos, os sambaquis são os maiores alvos de pesquisas arqueológicas, apresentando datações que se estendem de cerca de 6000 a 2000 AP (LIMA,1991). Conforme Prous (1992), o termo sambaqui origina-se das palavras do idioma tupi tamba (marisco) e ki (amontoado), tratando-se então de uma acumulação artificial de conchas de moluscos decorrentes da alimentação de grupos humanos.

Lima (1999/2000) destaca que à época do início das construções dos sambaquis houve o início do Ótimo Climático ${ }^{12}$. Segundo a autora, esse evento modificou a configuração da costa trazendo consequências significativas para a fauna, flora e, obviamente, para as populações humanas que ocupavam, no litoral, as áreas à beira-mar, mas que hoje não estão mais próximas à costa.

De acordo com Kneip (2004), a relação entre variações no nível médio do mar e sambaquis há muito desperta a atenção de pesquisadores e gera polêmicas: Krone, em pesquisa publicada em 1908, e Guerra, em 1950, aludiam a posição dos sambaquis aos processos de transgressão e regressão marinhos. Além desses pesquisadores, Fairbridge, em 1976, utilizou dados de sambaquis do Brasil para a construção de uma curva de variação do nível médio marinho. Porém, logo foi concluído que a construção de tais curvas apenas era possível a nível local ou regional, já que até mesmo trechos próximos podem mostrar variações de diversas naturezas na modificação do nível relativo do mar.

Mais tarde, Martin e colaboradores (1979; 1984) utilizaram-se de dados de sambaquis para a construção de curvas de variação do nível relativo do mar ao longo da costa brasileira ocorridas nos últimos 7000 anos desde o Holoceno, mas reconhecem que os sambaquis não são a melhor evidência para reconstrução espacial e temporal das antigas posições dos níveis marinhos, já que não é possível estabelecer diretamente a relação vertical entre suas bases e o nível do mar. Porém, os autores argumentam que a base dos sambaquis no início de sua construção

\footnotetext{
12 Período de maior aquecimento do planeta ocorrido há cerca de 8000 anos AP - no qual o aquecimento do planeta Terra ocasionou o derretimento das geleiras continentais e a consequente elevação do nível médio marinho, ou seja, uma grande porção do litoral atualmente exposto ficou submersa (FAIRCHILD et al, 2009).
} 
necessariamente deveria ter estado acima do nível da maré alta. Em contrapartida, a maioria dos sambaquis é datada de épocas mais recentes que o máximo holocênico, 5150 anos AP (PROUS, 1992).

Em 1985 foi publicado uma pesquisa realizada por Suguio e colaboradores, no qual os autores reuniram dados da sequência de níveis marinhos para o período Quaternário no litoral do Brasil e fizeram levantamentos em Salvador (BA), Ilhéus (BA), Caravelas (BA), Angra dos Reis (RJ), Santos (SP), Cananéia (SP), Paranaguá (PR) e Itajaí (SC), estabelecendo uma cronologia para a variação do nível médio do mar desde 7000 AP até o presente, podendo-se evidenciar curvas semelhantes em todas as regiões estudadas, mas com variação no valor máximo da transgressão marinha holocênica de 5100 anos AP ao longo da costa. Kneip (2004) utilizou-se dos dados de tal pesquisa, juntamente com de outras (em nível regional) publicados por Caruso Jr. em 1995 e Angulo e colaboradores em 1999, para descrever a variação do nível do mar na região do Camacho em sua Tese de Doutorado intitulada " O Povo da Lagoa: Uso do SIG para Modelamento e Simulação na Área Arqueológica do Camacho".

Até as primeiras décadas do século $\mathrm{XX}$, acreditava-se que os sambaquis representassem depósitos naturais correspondentes a terraços marinhos formados em condições de nível do mar mais alto do que o atual (GLIESH 1930; BACKHEUSER, 1945). A essa época, conforme Kneip (1977), as pesquisas em sambaquis foram realizadas por especialistas em Geologia e Geomorfologia Costeira, objetivando obtenção de dados relacionados às modificações da linha de costa, questionando se sambaquis poderiam ou não ser utilizados como indicadores de variações do nível médio marinho.

Esta hipótese foi contraposta mais tarde, postulando-se que esses sítios representavam construções de grupos caçadores-coletores-pescadores organizados socialmente na forma de bandos, com alta mobilidade territorial e com a subsistência baseada especialmente na coleta de moluscos. (LEONARDOS, 1938). Os sambaquis eram, até então, interpretados como áreas de descarte dos restos da alimentação, principalmente de conchas dos moluscos.

Porém, na década de 1990, pesquisas realizadas por Figuti (1992) com base nos aspectos zooarqueológicos dos sambaquis apontaram que os peixes eram predominantes na alimentação daquelas populações e que as conchas não significavam apenas restos de alimentação, mas também eram empregadas como 
matéria prima para a construção dos sambaquis. De acordo com Gaspar e colaboradores (1999), essas estruturas então passaram a ser reconhecidas também como marcos territoriais que podem indicar organização social complexa e menor mobilidade territorial.

No Brasil, onde os sambaquis se apresentam próximo ao delta do rio Amazonas e desde o sul da Bahia até o sul do Paraná (LIMA, 1991; BANDEIRA, 2008), podese observar que variam em aspectos morfológicos, estruturais e composicionais. Acredita-se que a consideração de tais variedades culturais inter-regionais encontradas são de extrema importância para a interpretação desses grupos no Brasil (PLENS, 2007).

Conforme observado por Lima (1999/2000), esses sítios apresentam as mais diversas formas e tamanhos com média entre 2 a 3 metros de altura, mas com altitudes de cerca de 30 metros ao sul (Santa Catarina), diminuindo à medida que se avança em direção ao Sudeste. A autora destaca que tais elevações são resultantes, em geral, da mistura de conchas (em grande parte fragmentadas) e sedimento, dispostos em camadas sobrepostas, entrecruzadas e entrecortadas sucessivamente. Essas complexas sequências estratigráficas correspondem a seguidas ocupações que utilizaram aquele espaço durante centenas ou milhares de anos.

Os sítios arqueológicos (sambaqui, abrigo, etc.) são definidos a partir da apresentação de certas características (assentamento, ritos funerários, entre outros). De acordo com Gonzalez (2005), o que diferencia os sambaquis dos concheiros naturais é a presença de sepultamentos, vestígios de fogueiras e artefatos.

Nesse sentido, de acordo com Ténório (2004), a identificação da cultura sambaquieira vem sendo abordada de diferentes maneiras. A autora destaca que as primeiras pesquisas sobre o assunto vieram de Serrano, que defendia que sambaquis do Sul obrigatoriamente apresentam zoólitos ${ }^{13}$ em sua fácies meridional (até São Paulo), e na fácies setentrional (a partir de São Paulo) não apresentam zoólitos. Ainda segundo Tenório (2004), Piazza recorreu a critérios exclusivamente malacológicos (predominância de certas espécies de conchas) para classificar as

\footnotetext{
${ }^{13}$ Conforme explanado por Lima (1999/2000), zoólitos são esculturas zoomorfas altamente complexas tanto em confecção quanto em elaboração feitas em rochas como basalto, diabásio e diorito ou em ossos de cetáceos. Tais esculturas, conforme a autora, são "concebidas dentro de rígidas regras estilísticas, retratam o universo faunístico com o qual essas populações interagiam em seu cotidiano (...), além de formas humanas e objetos com caprichosas formas geométricas."
} 
fases da cultura sambaquiana, o que também foi utilizado por Mendonça de Souza (fases) e Heredia et al (unidades culturais).

De acordo com Lima (1999/2000), Serrano também destacou a ocorrência de artefatos elaborados como argolas, esferas, discos perfurados, fusos, tembetás, pratos, tigelas, etc., confeccionados em rochas fragmentadas geralmente muito duras, como diabásio e diorito em sambaquis do litoral sul, exclusivamente no trecho entre São Paulo e Rio Grande do Sul.

O fato de, ao longo do litoral brasileiro apresentarem-se sítios com maior ou menor quantidade de conchas, fez com que à partir da década de 1970 houvesse debates que culminaram até mesmo na interdição ao uso do termo sambaqui para se referir a ocupações litorâneas (TENÓRIO, 2004).

Lima (1999/2000), ao observar variações no conteúdo faunístico em sambaquis do Rio de Janeiro, defende que as diferentes densidades de conchas se devem à exploração insustentável nos bancos de moluscos e ao crescimento demográfico, não a opções culturais. Também é importante observar que a pesquisadora, conforme Tenório (2004), propõe que o litoral tenha sido ocupado por povos de diferentes sistemas culturais vindos do interior do Brasil.

Lima (1999/2000) apoia a ideia de que os povos vindos do interior rapidamente se adaptaram à vida no litoral, sendo absorvidos culturalmente por populações já bem adaptadas ao ambiente, favorecendo a manutenção de uma cultura dos sambaquis.

Tenório (2004) faz um resumo das características da cultura material encontrada ao longo do litoral desde o Rio Grande do Sul ao Rio de janeiro e destaca que apesar da diminuição da presença de zoólitos culminando com a ausência no Rio de Janeiro, a diferença dos materiais líticos encontrados ao longo do litoral ou a maior variabilidade de itens de origem malacológica no Rio de Janeiro não podem expressar diferença cultural, se comparada a outros elementos como a homogeneidade da indústria óssea. A exemplo de Lima 1999/2000), a autora defende que a variabilidade regional observada pode estar relacionada à absorção de novos elementos culturais, provavelmente vindos de outros grupos ainda não adaptados ao litoral, e à criação de fatores de etnicidade que atuariam, por exemplo, sobre as maneiras de produção de artefatos ou de elementos rituais.

Apesar da intensidade das pesquisas, Kneip (1987) destaca que ainda não identificou-se a forma e a dimensão das unidades habitacionais, o que foi reiterado por Prous (1992), que observa a ausência de dados suficientes que possam dar 
embasamento para a caracterização das estruturas de habitação dos sambaquis. Isso foi verificado também por Lima (1999/2000) e Gaspar (2003), que notam que raros sítios apresentaram, até aquele momento, vestígios dessas estruturas; um desses é o sítio Corondó, no Rio de Janeiro.

Com relação às matérias-primas para confecção da cultura material, Lima (1999/2000) destaca que, de acordo com as pesquisas, salvo raras exceções, todas são encontradas facilmente em abundância no ambiente costeiro e são constituídas basicamente de rochas básicas, quartzos, conchas, ossos e dentes de animais, além de materiais perecíveis que dificilmente se preservam como fibras vegetais e madeiras. Além disso, ainda conforme Lima (1999/2000), também eram utilizadas matérias-primas raras como ossos e bulas timpânicas de mamíferos marinhos obtidos através de encalhes e material exógeno como rochas recorrentes na região planáltica, mas inexistentes no ambiente litorâneo.

Prous (1992) observa que a indústria lítica dos sambaquis apresenta grande quantidade de artefatos polidos, picoteados ou objetos líticos utlilizados in natura, além de material lascado. De acordo com Lima (1999/2000), a principal matériaprima utilizada é o quartzo, mineral mais abundante nos sambaquis do litoral sudeste, utilizando-se sobretudo seixos como bigornas e percutores, e na confecção de facas, raspadores, furadores, etc.

O material ósseo é bem conservado nos sambaquis, ao contrário do que ocorre em sítios arqueológicos do interior brasileiro. Isso se deve ao fato de a grande concentração de conchas, fonte de calcário, realizar a correção da acidez do solo, propiciando um ambiente próprio para a conservação desses materiais. Conforme Prous (1992), os ossos foram bastante utilizados na fabricação de objetos perfurantes de forma complexa e estreita (com base em matérias primas como diáfises de mamíferos e aves, vértebras, costelas, e bula timpânica de baleia), impossíveis de serem feitas com material lítico. Os instrumentos ósseos geralmente encontrados são: pontas de dardo e de projétil, furadores, agulhas, espátulas, recipientes e anzóis (LIMA, 1999/2000).

Em relação ao material malacológico, de acordo com Prous (1992), este constituía a maior parte dos instrumentos de corte, mas também incluem raspadores, recipientes, colheres, etc., além de ser utilizado como adorno, geralmente na forma de pingentes. 
Conforme observado em Lima (1999/2000), a pesquisa de sambaquis pode ser considerada um tanto abrangente considerando-se desde a região Sul do Brasil até o estado do Rio de Janeiro, através dos trabalhos desenvolvidos por pesquisadores como Dorath Pinto Uchôa, Caio Del Rio Garcia, Paulo DeBlasis, Levy Figuti, Lina Maria Kneip, Maria Dulce Gaspar, Tânia Andrade Lima, dentre outros.

Em relação ao estado do Espírito Santo, de acordo com Lima (1999/2000), pesquisas em sambaquis foram realizadas por Mendonça de Souza ao sul do Estado, na cidade de Rio Novo do Sul e por Suguio, Martin e Dominguez ao norte do Espírito Santo na região próxima ao Rio Doce.

\section{Acampamentos conchíferos:}

O termo "acampamento conchífero" nem sempre existiu em Arqueologia Brasileira. De acordo com um histórico levantado Simões (2014), essa tipologia para determinados sítios arqueológicos surgiu de maneira formal em 1967 através de uma pesquisa publicada por Beltrão e Kneip, cujo fulcro era a classificação de sítios encontrados no litoral fluminense.

Simões (2014) pontua que o surgimento do termo ocorreu em decorrência do fato de que era consenso entre pesquisadores que depósitos conchíferos de origem antrópica deveriam apresentar, necessariamente, acúmulo de conchas em um mesmo local, "formando montes convexos onde predominava a presença de moluscos". Dessa forma, ainda segundo a autora, os sítios que não obedeciam a esses padrões, cuja camada de conchas era pequena, rasa e por vezes espaçada, não encontravam uma classificação pré-existente na qual pudessem ser inseridos.

Nesse sentido, Beltrão e Kneip (1967), denominaram os acampamentos conchíferos como aldeamentos ou locais de habitação temporários formados por conchas acumuladas em "fossas culinárias" que podem alcançar até 4,0m de extensão por 1,5m de profundidade, dispostas juntamente com cacos de cerâmica, fragmentos de ossos de animais, carvão e outros.

Uchôa (2009) denota que a morfologia desses sítios apresenta-se pouco acidentada, encontrando-se poucas conchas, compensadas por grande quantidade de restos de peixes, poucos restos de mamíferos e tartarugas, mas com bastante diversidade, concentrados em bolsões. 
Prous (1992) utiliza o termo "acampamento litorâneo", determinando-o para sítios arqueológicos cujos vestígios culturais estão dispostos numa matriz sedimentar composta, na qual os elementos minerais são a maior parte e são misturados a conchas de moluscos, geralmente concentradas em bolsões ou lentes de superfície limitadas, enquanto o sedimento arenoso apresenta grande quantidade de restos de peixes. Prous (1992) destaca que os povos dos sambaquis não deixaram de pescar, conforme evidências, mas dada a quantidade de restos de peixes em comparação a moluscos, os povos que construíram os acampamentos litorâneos tinham a base alimentar bem mais centrada nos produtos da pesca.

Conforme Beltrão e Kneip (1967), tais sítios estão ligados a ocupações por grupos cuja subsistência baseava-se na pesca, coleta de moluscos, caça e agricultura com ocorrência por volta de 1000 anos AP.

Considerando as diferentes características existentes entre acampamentos conchíferos (ou litorâneos) ao longo da costa brasileira, Prous (1992) os divide em três categorias: acampamentos meridionais (compreendendo do Rio Grande do Sul a São Paulo), acampamentos do litoral central (Rio de Janeiro e Espírito Santo) e acampamentos do litoral nordestino (Bahia e Maranhão). Considerando as características dos diferentes acampamentos de ocorrência na região Sudeste, de acordo com Prous (1992) tem-se:

- acampamentos meridionais - de superfície variável, os maiores são encontrados em Santa Catarina (Tapera) e os menores em São Paulo (Buracão e Tenório). As fogueiras são recorrentes, assim como grande número de sepultamentos, apresentando estruturas simples, com cova rasa e dentro da qual o corpo é depositado em posições que variam de uma região a outra. Apresentam acompanhamento funerário lítico geralmente associado às costas do morto e raramente à cabeça, assim como placas de ossos de baleia cobrindo os pés. As oferendas, mais comuns aos sepultamentos infantis, são geralmente adornos de conchas e dentes de seláquios; e para os adultos, são comuns os artefatos líticos (seixos, batedores e machados) e ósseos (pontas, placas, ou até mesmo animais inteiros).

Tais acampamentos podem ou não apresentar cerâmica, sendo os mais recentes, com cerâmica. Nos que não apresentam cerâmica, os vestígios líticos assemelhamse aos sambaquis com zoólitos, e os com cerâmica diferem pouco dos sambaquis 
sem zoólitos, apresentando quebra-cocos de diabásio ou gnaisse, machados polidos ou semipolidos, lascas de diabásio, peças fusiforme alongadas, etc.

A indústria óssea é pouco diversificada em relação aos sambaquis, e os artefatos ósseos que se destacam são as pontas (simples ou duplas) feitas a partir de diáfise de pássaro ou mamífero, espinhas de peixe e lâminas de ossos de baleia. As conchas são pouco transformadas, sendo utilizadas para corte (ostras) ou como adornos.

A cerâmica, quando existente, varia em quantidade de um sítio a outro, de dezenas de cacos a centenas, sendo, conforme já dito, de características simples.

- acampamentos do litoral central - associados por Prous (1992) à tradição Itaipu, nessa região tais sítios apresentam-se como pré-ceramistas e no Rio de Janeiro geralmente ocupam restingas, evitando os ambientes de mangue. Os situados próximos ao oceano, muitas vezes sobre sambaquis, recebendo diretamente a influência marítima, parecem ser os mais recentes (2000 AP - nível I do Sambaqui do Forte) enquanto os que se encontram nas imediações de lagoas, em praias lacustres, são os mais antigos (2400 e 4000 BP para Corondó e Malhada, respectivamente).

Construídos em locais ecologicamente privilegiados, esses acampamentos apresentam vestígios de zonas de refugo alimentar na forma de bolsões de conchas. Os enterramentos são encontrados desde a base arenosa estéril (Niterói) até todos os níveis (Corondó).

Os sepultamentos são em geral com acompanhamento funerário, mas de forma variada de local para local: corpos de bruços com pedras associadas às costas dos indivíduos e colares de conchas (Malhada), decúbito dorsal com um braço estendido e o outro com a mão na genitália acompanhado de seixos e ocre (Corondó), vértebras de peixes não perfuradas associada aos mortos (Forte), entre outros.

Em muitos sítios encontra-se artefatos de conchas, como pontas, polidores e adornos. Conforme descrito por Machado (1983), no sítio Corondó há evidências de forte abrasão dos dentes anteriores ao maxilar e grande frequência de cáries, o que não ocorre entre as populações dos sambaquis, indicando alimentação rica em carboidratos. Padrões parecidos também foram encontrados na camada I do sambaqui do Forte. 
O material lítico em geral é formado por lascas de quartzo e material polido a partir de seixos de granito, gnaisse, micaxisto e sobretudo diabásio. Os artefatos são principalmente raspadores, pontas, poucos machados e, em muitos sítios, grande quantidade de moletas e almofarizes, interpretado por Dias Júnior (1995) como evidências de uma provável agricultura incipiente, o que não pôde ser comprovado, mas certamente indicam que os vegetais tiveram papel fundamental na alimentação daqueles grupos, diferente do que ocorreu entre os construtores de sambaquis.

Por outro lado, a indústria óssea é bem semelhante à encontrada nos sambaquis dessa região, apresentando tanto pontas simples como duplas em grande quantidade, e eventualmente, vértebras de peixes perfuradas. A presença de numerosos ossos de mamíferos marinhos é recorrente em sítios de todo o litoral fluminense, mas as conchas são encontradas em quantidade bem reduzida, indicando sua baixa importância na dieta dessas populações.

\section{Breve caracterização dos sítios litorâneos do Espírito Santo:}

\section{A Arqueologia do Espírito Santo:}

De acordo com Teixeira (2002), as pesquisas arqueológicas no Espírito Santo tiveram início na década de 1930 através de Ferreira Meyer (1936), com pesquisa realizadas nas arcadas dentárias de esqueletos encontrados em sambaquis localizados na Baía de Vitória. Os sambaquis dessa região também foram alvo de pesquisas posteriores realizadas por Cunha $(1952 ; 1967 ; 1968 ; 1970)$, baseadas nos dentes dos esqueletos, porém, apresentam dados um tanto questionáveis.

Augusto Ruschi $(1953 ; 1954)$ dedicou-se durante pouco tempo à arqueologia da região montanhosa do Espírito Santo, em especial no município de Santa Tereza. Além dele, Aldemar Neves (1943) realizou pesquisa em um sítio localizado em um afluente do baixo rio São Mateus e Adam Orssich ${ }^{14}$ (1981 [1966]; 1977) fez relatos sobre os sambaquis localizados também na região norte capixaba.

${ }^{14} \mathrm{O}$ conde Adam Orssich de Slavetich, de origem luguslava, era geólogo, engenheiro de minas, agrônomo e doutor em Arqueologia pela Universidade de Viena. Migrou para o Brasil em 1951 
No final da década de 1960, Celso Perota iniciou suas pesquisas no Espírito Santo, e mais tarde, ocasionado pelo afastamento por motivos de saúde de Adam Orssich, assumiu as pesquisas do mesmo no extinto Museu de Arte e História da Universidade Federal do Espírito Santo (UFES) (hoje Museu Solar Monjardim), realizando levantamentos e pesquisas de campo em sítios arqueológicos localizados no Estado. Isso o levou tornar-se professor na Universidade Federal do Espírito Santo (UFES) e a ser responsável pelas pesquisas Programa Nacional de Pesquisas Arqueológicas (PRONAPA) no Estado do Espírito Santo junto.

As pesquisas de Perota iniciaram-se na região norte do Estado (1971a; 1971b), estendendo-se mais tarde para as demais regiões $(1974 ; 1975)$ e em 1979 ele defendeu seu Mestrado, orientado pela pela Prof ${ }^{\mathrm{a}} \mathrm{Dr}^{\mathrm{a}}$. Luciana Pallestrini. Mais trabalhos foram realizados posteriormente juntamente com outros pesquisadores (1987; 1988; 1995).

De acordo com relatórios elaborados por Perota para o PRONAPA (1971b; 1974), durante seu período de atuação, foram identificados seis sambaquis na região do litoral norte do Espírito Santo; quatro próximos ao rio São Mateus e dois no vale do rio Reis Magos (a $8 \mathrm{~km}$ da linha de costa). Além desses sítios, também foi localizado um sambaqui na região central do Estado, ilha de Vitória, no campus da Universidade Federal do Espírito Santo. Todos apresentaram indústria lítica baseada no quartzo como principal matéria prima.

Entre as décadas de 1980 e 1990, Martin, Suguio e colaboradores (1982; 1997) pesquisaram sambaquis do litoral norte ao realizar estudos sobre a evolução do Quaternário capixaba, em especial, da Planície Costeira do rio Doce.

Conforme Souza (2010), a partir da década de 1990, em cumprimento à Resolução CONAMA 001/88, que exige pesquisa arqueológica dentre os procedimentos para obtenção de licenciamento ambiental, a pesquisa arqueológica por contrato foi impulsionada no Espírito Santo, com o predomínio de sítios registrados e pesquisados por Celso Perota, Cristiane Lopes Machado e João Luiz

juntamente com sua esposa, a arqueóloga Elfride (doutora pela Universidade de Praga), e a convite da Faculdade de Filosofia da Universidade do Paraná, estudou os sambaquis do litoral paranaense. Mais tarde, trabalhou com pedras preciosas no vale do Rio Doce em Minas Gerais e mudou-se com sua família para Vila Velha, no Espírito Santo, onde desenvolveu com sua esposa pesquisas arqueológicas, falecendo em 1968 aos 73 anos de idade (ORSSICH, 1954; 1981). 
da Cunha Teixeira, podendo-se destacar também Solange Caldarelli, Maria Cristina Mineiro Scatamacchia (docente MAE-USP), entre outros.

Em 2002 Teixeira defendeu sua Dissertação de Mestrado, orientado pelo Prof. Dr. Levy Figuti, na qual aborda o levantamento de sítios arqueológicos da região norte do Estado, e em 2010 Letícia Moura Simões de Souza também finalizou pesquisa de Mestrado, sob a orientação da Prof ${ }^{a} \operatorname{Dr}^{a}$. Tânia Andrade Lima, sobre a ocupação Tupiguarani entre os municípios de Anchieta e Piúma, região sul do Estado.

Sambaquis:

De acordo com Souza (2010), os sambaquis apresentam-se ao longo de toda a costa capixaba, com registros e pesquisas realizados essencialmente através da arqueologia de contrato. Teixeira (2002), destaca que esses sítios se apresentam com até $800 \mathrm{~m}^{2}$ e baixa altitude média $(2 \mathrm{~m})$, não destacando-se na paisagem.

Além disso, conforme levantamento realizado por Souza (2010), os sambaquis do Espírito Santo apresentam cronologia entre 3000 e 4000 anos AP, material lítico lascado (em sua maioria) e polido e semi-polido, grande quantidade de carapaças de moluscos, com predomínio da espécie Ostrea sp., sepultamentos sobrepostos, além de artefatos ósseos como pontas de projétil e dentes perfurados.

Acampamentos conchíferos:

A exemplo dos sambaquis, de acordo com Souza (2010), os acampamentos conchíferos também estendem-se ao longo do litoral capixaba. Dessa forma, foram utilizados como base para sua caracterização, as pesquisas de Teixeira (2002) e Perota (1971b) que englobam sítios ao norte do Estado, Perota e Assis (1993), região centro-norte, Scatamacchia $(2007 ; 2008)$ e Caldarelli $(2008)$ que envolve sítios localizados ao sul do Espírito Santo.

De acordo com as observações de Souza (2010), esses sítios apresentam pouca extensão, variando entre 200 a $2000 \mathrm{~m}^{2}$, alta densidade de conchas, quando 
localizados ao norte do Estado, e pouca densidade ao sul, com estrato arqueológico variando entre $20-75 \mathrm{~cm}$ de espessura.

Os sítios, em geral, apresentam indústria lítica com material lascado (composta predominantemente de quartzo, raramente com retoque e com classificações: raspadores, facas e perfuradores), e polido, utilizado em sua maioria na forma bruta (seixos), classificados em: machados, batedores e pesos de rede.

Além disso, há a presença de carapaças de moluscos em baixa concentração e a presença de ossos de peixe e animais terrestres, além de artefatos ósseos como pontas de projéteis e vértebras de peixes perfuradas.

Como se pôde observar, ainda há muito a ser realizado em relação às pesquisas arqueológicas acadêmicas no Espírito Santo, já que, nesse Estado estas começaram a ser desenvolvidas na primeira metade do século $X X$, contando, até o presente, cerca de 300 pesquisas arqueológicas efetuadas, conforme consta em relatórios e publicações presentes no IPHAN (Instituto do Patrimônio Histórico e Artístico Nacional). Desses trabalhos, 90\% correspondem a pesquisas no âmbito da arqueologia preventiva e apenas os $10 \%$ restantes dividem-se em pesquisas acadêmicas, planos de manejo e gestão, além de projetos de restauração (MACHADO, 2010).

Por esse motivo, acredita-se que em adição à caracterização de sítios arqueológicos do Espírito Santo, faz-se necessária a apresentação, mesmo que breve, das características de sítios litorâneos do Rio de Janeiro e de São Paulo.

\section{Breve caracterização dos sítios litorâneos do Rio de Janeiro:}

De acordo com Kneip (1976), as pesquisas em sambaquis do Rio de Janeiro iniciaram-se nas primeiras décadas do século XX, através de Backheuser, Abreu, Leonardos e Guerra; todos preocupados com a solução de problemas relacionados às modificações do nível médio marinho. Mais tarde, em 1946, Serrano dedicou-se à primeira tentativa de classificação dos sambaquis em relação a fases culturais: fase sul, fase arcaica, fase média e fase amazônica; sendo que sambaquis do Rio de Janeiro e Espírito Santo fariam parte da fase média.

Beltrão (1976) observa que entre 1960 e 1963, Salles Cunha dedica-se ao estudo de patologias dentárias de humanos provenientes de sambaquis, descrevendo 
aspectos arqueológicos e ecológicos da baixada de Guaratiba-Sepetiba (Guanabara), publicando uma série de artigos (Cunha, 1960; 1963).

$\mathrm{Na}$ segunda metade dos anos 1960, Beltrão realiza estudos em Guanabara e defende sua Tese de Doutorado sobre a pré-história do Rio de Janeiro em 1969 (BELTRÃO, 1969). Também em 1969, Dias Júnior propõe a fase Itaipu após pesquisas realizadas no sítio Corondó e observações em outros sítios com características semelhantes (DIAS JÚNIOR. 1969) e, à mesma época, Kneip inicia suas pesquisas em sambaquis do Rio de Janeiro, publicando sua Tese de Doutorado baseada em sítios do litoral de Cabo Frio em 1977 (KNEIP, 1977). Depois, juntamente com a Prof ${ }^{a} \mathrm{Dr}^{\mathrm{a}}$. Luciana Pallestrini, Kneip realizou pesquisas no município de Saquarema (KNEIP; PALLESTRINI, 1990).

Em 1983 Cheuiche-Machado defende sua Tese de Doutorado sobre os remanescentes ósseos do sítio Corondó, na qual prova que a população que habitou a área tinha uma dieta rica em carboidratos (MACHADO, 1983), e em 1991 Lima e Gaspar defendem suas Teses de Doutorado sobre os padrões de subsistência e organização social (respectivamente) dos grupos pescadores-coletores-caçadores do Rio de Janeiro (LIMA, 1991; GASPAR, 1991).

Em relação às características dos sambaquis do Estado do Rio de Janeiro, conforme abordado anteriormente, Lima (1999/2000), ao citar Serrano, observou que características como a presença de zoólitos diferenciam os sambaquis de São Paulo ao Rio Grande do Sul e do Rio de Janeiro. Porém, outras características dos sambaquis do Rio de Janeiro devem ser abordadas.

Conforme Gaspar (2003), predominam entre Ilha Grande e o Delta do Paraíba do Sul no Rio de Janeiro, sambaquis cuja camada arqueológica apresenta pequena espessura com, em geral, três camadas estratigráficas distintas (sedimento base, acúmulo de restos faunísticos e restos faunísticos associados a fragmentos de cerâmica e/ou restos coloniais). Segundo a autora, existem variações, como no caso do sítio Salinas Peroano, que apresenta bolsões isolados de conchas. Os restos faunísticos são compostos basicamente por:

- moluscos - Anomalocardia brasiliana, Ostrea sp., Anadara notabilis, Megalobulimus sp., Olivancillaria sp., Astraea sp., Lucina pectinata, Strombus costatus, Strombus pugilis, Trachycardium muricatum, Arca imbricata, Taumastus 
sp., e Calista maculata mais recorrentes e Pomacea canaliculata estrita a um número menor de sítios;

- peixes - Galeocerdo sp, Negaprion sp, Hipoprion sp, Eugomphodus sp, Isurus sp, Alopias sp, Galeohurmus sp, Edontaspis taurus, Carcharodon carcharias, Carcharhinus maou, Carcharhinus limbatus, Carcharhinus plumbeus e Squaliformes, além de Carax sp (xaréu). Além dessas espécies, em menor quantidade são encontrados esporões de raias, restos de bagre e inúmeros restos de peixes de pequeno porte, dificílimos de serem identificados.

- mamíferos - poucos sítios apresentaram restos de mamíferos. Dentre as espécies identificadas tem-se: Alouatta $s p$, Callitrhix sp, Cebus apela, Felis $s p$, Marmosa sp, Mazama sp, Tapirus terrestres, Didelphis sp, Cavia sp, Dasypus sp, Hidrochaeris sp, Tayassu sp, Tayassu tayacu e Dasyprocta agouti, além de mamíferos marinhos como Otaridae, golfinho e baleia.

- outros - restos de aves, répteis, crustáceos, equinodermas, anfíbios e vegetais foram identificados em poucos sítios, sendo que répteis e vegetais foram encontrados apenas no sítio Corondó, que é defendido por Dias Júnior (1992b) como um sítio de cultura sambaquieira adaptada a novos padrões ambientais.

Gaspar (2003) também destaca que marcas de fogueira são recorrentes, mas que marcas de estacas inseridas no solo são raras. Além disso, a autora afirma que restos humanos foram encontrados em quase todos os sítios com o mesmo padrão de enterramento: enterramentos em grupo, e orientações e posições do corpo (decúbito dorsal, decúbito lateral, fletido, decúbito ventral e distendido) e da face (maioria para cima e minoria Norte) recorrentes em todos os sítios. Enterramentos de crianças sempre apresentam acompanhamento funerário elaborado e de adultos exibem adornos ou acompanhamento de artefatos: vértebras adornando membros superiores e inferiores, pontas em diferentes partes do corpo (pescoço, cabeça e membros superiores e inferiores) associadas geralmente a indivíduos adultos do gênero masculino.

Ainda citando Gaspar (2003), a indústria lítica apresentada nos sambaquis da área entre llha Grande e Delta do Paraíba do Sul no Rio de Janeiro é constituída de quartzo lascado com dimensões entre 6 e $0,5 \mathrm{~cm}$ de comprimento, e artefatos de seixo ou blocos de gnaisse, diabático, basalto e quartzo com ou sem polimento. De acordo com a autora, as fontes de quartzo muitas vezes não era próxima aos sítios, 
havendo a necessidade de busca de matéria-prima de boa qualidade no interior de veios de quartzo. Os materiais encontrados foram classificados como: lascas bipolares, pontas, lâminas de machado, almofarizes, alisadores, polidores, perfuradores, raspadores, entre outros.

Gaspar (2003) observa que artefatos confeccionados a partir de ossos e dentes são recorrentes em todos os sítios, utilizados funcionalmente (bipontas, pontas planas, agulhas, furadores, espátulas e um apito) e para adornos (colares, pulseiras, etc.).

Segundo Gaspar (2003), a indústria conchífera provavelmente era utilizada em sua maioria como raspadores e as conchas que apresentavam orifício, como adornos. Conchas também já foram encontradas como acompanhamento funerário.

Gaspar (2003) reitera o fato de que de acordo com seus levantamentos, os grupos que viveram na faixa compreendida entre Ilha Grande e o Delta do Paraíba do Sul utilizavam-se dos recursos do litoral para sua subsistência, com atividades como caça (pela presença de várias espécies terrestres), coleta (principalmente de moluscos) e pesca de animais marinhos de vários portes, o que foi confirmado para o restante do Estado do Rio de Janeiro por Tenório (1995) e Lima (1995).

Segundo Gaspar (2003), a escolha de locais elevados, ou que ao menos se destacassem na paisagem era recorrente e que as dimensões dos sítios variam entre 1000 e $1500 \mathrm{~m}^{2}$, com ocupação que perdurou ao menos 4000 anos na região.

\section{Breve caracterização dos sítios litorâneos de São Paulo:}

Um pouco de dificuldade foi encontrada para se construir uma caracterização dos sambaquis de São Paulo. Mas isso não se deveu à ausência de dados, muito bem exposto através das pesquisas desenvolvidas por Pallestrini, Guidon, Uchôa, Del Rio, Figuti, entre outros, mas a não encontrar bibliografia que se dedicasse a um resumo; problema não encontrado ao pesquisar as características de sambaquis do Rio de Janeiro.

Dessa forma, como estratégia, foram realizadas análises de pesquisas publicadas na forma de artigos, além de Teses e Dissertações que oferecessem um resumo das características de certa quantidade de sambaquis marítimos de São Paulo, e com base nos dados levantados a partir desses trabalhos, fazer um 
levantamento dos padrões que poderiam caracterizar, mesmo que de maneira simples, os sambaquis dessa região.

Para isso, foram escolhidas as pesquisas desenvolvidas por Sérgio Francisco Serafim Monteiro da Silva (2005) na Baixada Santista, Dorath Pinto Uchôa (2007) na Baixada Santista e litoral norte de São Paulo e Mateus Manuel Gonzalez (2005) na Baixada Santista e litoral norte, além de Daniela Maria Alves (2011) também na Baixada Santista e litoral norte paulista.

De acordo com Silva (2005), os primeiros estudos arqueológicos no litoral de São Paulo foram realizados por Loefgren e Krone na primeira década do século XX, vinculados à Comissão Geographica e Geológica do Estado de São Paulo, quando foram levantadas informações sobre 136 sambaquis da Baixada Santista e Cananéia-Iguape.

Segundo Gonzalez (2005), os estudos em sambaquis na Baixada Santista tiveram início na década de 1950 com Paulo Duarte e equipe, com o intuito de salválos da destruição pela exploração econômica. Tais pesquisas culminaram na organização de missões estrangeiras, numa das quais veio ao Brasil o casal Annette e Joseph Emperaire, em busca de esclarecimentos a respeito do surgimento do Homem no litoral sul-americano e da construção de uma síntese espacial e cronológica para a arqueologia brasileira.

Silva (2001) destaca que na década de 1960, Luciana Pallestrini, Niéde Guidon e equipe iniciaram a realização de pesquisas no sambaqui Mar Casado, e logo depois no sambaqui Buracão, já parcialmente destruído pela construção da estrada Guarujá-Bertioga (Guidon; Pallestrini, 1962; Guidon, 1964; Pallestrini, 1964). De acordo com Uchôa (2007), em 1965 Paulo Duarte iniciou os estudos no sambaqui Piaçaguera, sob a coordenação de Caio Del Rio Garcia (1972).

Conforme Gonzalez (2005), no litoral norte paulista, as pesquisas foram iniciadas por Dorath Pinto Uchôa, entre o final da década de 1960 e início de 1970 (UCHÔA, 1973). Durante muitos anos foram desenvolvidas pesquisas nessa região sob coordenação dessa pesquisadora.

Mais tarde, em 1992, através de sua pesquisa de Doutorado sobre os sambaquis Cosipa 1, 2 e 4 na região de Cubatão, Figuti constatou que os peixes eram predominantes na alimentação populações sambaquieiras e que as conchas não significavam apenas restos de alimentação, mas também eram empregadas como matéria prima para a construção dos sambaquis (Figuti, 1992). 
Quanto às características dos sambaquis paulistas, conforme citado anteriormente, Tenório (2004) se atenta ao fato de os sambaquis de São Paulo apresentarem-se de forma parecida aos encontrados no Sul sob diversos aspectos, entre eles, a semelhança na indústria lítica. Alves (2011) destaca que isso pode ser indício de que esses grupos partilhavam de uma mesma tradição cultural com perdas e acréscimos decorrentes de aperfeiçoamento tecnológico adaptativo ou até mesmo por contato e incorporação cultural de outras populações.

De acordo com o observado na pesquisa de Gonzalez (2005), os sambaquis do litoral central paulista apresentam altitude média de 5 metros, podendo-se destacar o sambaqui denominado sítio Piaçaguera pesquisado por Uchôa (2007), que não apresentou elevação nem intensa concentração de conchas, o que pode indicar uma forma de adaptação local específica. Segundo Uchôa (1980), essas diferenças também foram identificadas entre sítios do litoral sul e central, podendo refletir as diferenciações temporais e espaciais na vida desses grupos.

Conforme observado nas pesquisas, no litoral sudeste de São Paulo há a ocorrência de sambaquis cujas conchas de moluscos são presentes em toda a sua extensão, como Mar Casado e Piaçaguera e outros, nos quais tais estruturas são concentradas na forma de bolsões, como o Tenório e Buracão, que não são considerados sambaquis por Prous (1992), mas como acampamentos litorâneos. Diferente do que ocorre no Rio de Janeiro, segundo Gaspar (2003), pôde-se inferir que sambaquis com estruturas em bolsões são relativamente recorrentes em São Paulo.

Os vestígios faunísticos encontrados em sambaquis de São Paulo são compostos basicamente por:

moluscos - Olivella verreauxi, Phacoides pectinatus, Trachicardium muricatum, Polinices hepaticus, Bulla striata, Pinctada $s p$, Strombus $s p$, Mitella sp, Crassostrea $s p$, Astrea $s p$, Anomalocardia sp, Thais sp, Lucina $s p$ (principalmente em bolsões com carvão), Cyprea sp, Spondylus americanus, entre outros;

peixes - foram encontrados restos de peixes de todos os portes, como Tachysurus spixii, Galeocerdo curvieri, Carcharodon carcharias, Sphyrna sp, Odontaspis taurus, Prionace sp,entre outros;

mamíferos - Aloutta sp, Hydrochoerus hydrocoeris, Tayassu pecari, Nasua narica, Cuniculus paca, Panthera onca, Sotallia, sp, entre outros; 
outros - em menor quantidade, foram encontrados crustáceos (Ucides cordatus), répteis (Caiman spl), quelônios e seláquios.

Durante a consulta às pesquisas, pôde ser observado que restos humanos puderam ser encontrados na maioria dos sambaquis de São Paulo, acompanhando os padrões de enterramento típicos de cultura sambaquieira: em grupo, orientações e posições do corpo e da face, com acompanhamento funerário de conchas ou fragmentos de rochas. Porém, conforme notado por Silva (2001), pode-se observar também padrões de enterramento diferenciados (cova rasa ou profunda; com ou sem acompanhamento funerário).

Com relação à indústria lítica, observou-se a presença de líticos lascados ou polidos com matéria-prima constituída principalmente por diabásio, quartzo de veio, gnaisse, quartzito, e seixos (muitas vezes em grande quantidade), classificados como machados (lascados ou polidos), batedores, lascas, fragmentos, bifaces, lâminas, etc.

Muitos artefatos encontrados tinham ossos de peixes e mamíferos como matériaprima, principalmente na forma de pontas de projétil. Além disso, muitos dentes de animais eram utilizados como adorno e instrumento de trabalho. Em adição, as valvas de conchas também eram utilizadas como instrumento, principalmente como raspadores e como adorno.

Com base no que foi observado, pode-se concluir que os grupos que habitavam o litoral paulista, a exemplo do que também ocorreu em sambaquis de outras localidades, em sua maioria escolhiam locais próximos à costa, de preferência elevados ou que se destacassem na paisagem e ricos em alimentos. Dada a diversidade de fontes alimentícias encontradas (moluscos, peixes, mamíferos marinhos e terrestres, entre outros), pode-se inferir que para sua subsistência tais grupos caçavam, pescava e coletavam.

Porém, sabe-se que o exposto acima foi uma tentativa de reunião de dados para que se tivesse ao menos uma ideia das características dos sambaquis do litoral de São Paulo. Para que se faça um levantamento mais consistente é necessário que se considere uma gama muito maior de sítios arqueológicos desse tipo e que se englobe ainda mais a linha de costa paulista. 


\subsubsection{O paleoambiente do litoral do Espírito Santo:}

No Espírito Santo, nas regiões de Vitória, Guarapari e Anchieta, depósitos de manguezais são bem desenvolvidos, caracterizados por apresentarem sedimentos em geral argilosos, localmente arenosos e ricos em matéria orgânica, podendo conter fragmentos de madeira e conchas de moluscos.

De acordo com Martin et al (1997), a presença em abundância desses depósitos indica fases de maior extensão das paleolagunas. Os manguezais chegaram a ocupar áreas maiores durante os últimos 7000 anos, mas estas foram diminuindo gradativamente.

O desenvolvimento de manguezais está diretamente ligado a interações continente-oceano e sua expansão é determinada pela sua topografia em relação ao nível do mar, inclusive podendo migrar de acordo com mudanças no nível marinho, ou seja, são ecossistemas altamente suscetíveis a mudanças climáticas e marinhas (PESSENDA et al., 2012).

Dominguez et al. (1992) afirmam que a sedimentação da planície costeira do litoral leste e nordeste do Brasil foi modelada a partir de: 1) variações do nível do mar, que através das trasgressões favoreceu o surgimento de sistemas ilha barreiralaguna e das regressões promoveu a progradação da planície costeira; 2) mudanças climáticas, que alteram o regime de chuvas e aporte sedimentar; e 3) fenômenos de circulação atmosférica que controlam o ângulo de incidência das ondas sobre a costa, gerando a deriva litorânea que "desenha" a linha de costa.

Algumas evidências de NMM mais baixo que o atual em Guarapari-ES são os afloramentos de bancos de arenito (beach rocks) que ocorrem nas praias da região central da cidade, apresentando-se também na planície costeira do rio Doce, ao sul da foz do rio Jucu e no leito do canal que drena a Lagoa da Boa Vista, ao norte da planície do rio Itabapoana, no litoral sul do Espírito Santo (MARTIN et al, 1997).

Em relação à vegetação, análises palinológicas realizadas por Veríssimo et al. (2012) no Parque Nacional do Caparaó, sudoeste do estado do Espírito Santo e a $245 \mathrm{~km}$ do sítio Limeira, indicam que de 9000 a 2700 AP, havia no local a frequência de espécimes típicos de florestas úmidas de altitude, apesar de hoje a vegetação ser de campo, o que indica um espaço de tempo que esta região apresentou clima mais úmido. 
Pesquisas paleoambientais no litoral do Espírito Santo estão sendo realizadas por Luiz Carlos Ruiz Pessenda do Centro de Energia Nuclear na Agricultura da Universidade de São Paulo (CENA-USP), englobando desde a região norte até a região sul do Estado. No âmbito dessa pesquisa estão incluídas biocronstruções de vermetídeos no município de Guarapari, onde se localiza o sítio arqueológico Limeira, para a obtenção de curvas de variação de nível relativo do mar e concentrações de $\mathrm{C}^{13} \mathrm{e} \mathrm{O}^{18}$ das carapaças de moluscos nos últimos 8000 anos, afim de que, em comparação com resultados obtidos em outras regiões da costa brasileira, seja elaborado um modelo de mudança do padrão de circulação oceânica no Holoceno superior e de mudanças climáticas associadas.

Até o momento foram divulgados por Buso Jr et al. (2013; 2014) resultados de pesquisas realizadas na Reserva Biológica de Sooretama, região norte do Espírito Santo - próxima ao Delta do Rio Doce, localizada a $209 \mathrm{~km}$ de distância do sítio Limeira e a $80 \mathrm{~km}$ do litoral - nos quais se observa que há registros da presença de vegetação florestal desde 7700 anos AP, indicando a manutenção da cobertura florestal ao longo de todo o Holoceno no local e, consequentemente, condições climáticas úmidas o suficiente para tal. Segundo levantamento bibliográfico do autor, à essa época as frentes frias de origem polar tinham maior frequência e intensidade nas menores latitudes da América do Sul; o encontro dessas frentes com as massas de ar quente pode ter sido responsável por essa umidade. Esse padrão foi o mesmo encontrado por Veríssimo et al. (2012) a sudoeste do Espírito Santo, conforme supracitado.

Ainda de acordo com Buso Jr. et al. (2014), a partir de 4000 anos AP as condições climáticas na região eram semelhantes às atuais, apresentando estação seca durante o inverno, já que nesse período as massas de ar polar passaram a ficar restritas a latitudes mais ao sul do Brasil.

Outros resultados de pesquisas desse projeto realizadas na mesma região também foram publicados. Em entrevista publicada em 2012 no periódico Revista FAPESP, o Prof. Dr. Luiz Carlos Ruiz Pessenda (CENA-USP) afirmou que a 6000 anos AP o nível médio marinho ao longo da costa do Espírito Santo estava aproximadamente $4 \mathrm{~m}$ mais elevado que o encontrado hoje e que muitos locais que atualmente são praias eram antes manguezais. 


\subsection{CONTEXTO AMBIENTAL DO SÍTIO LIMEIRA:}

\subsubsection{Localização e contextualização:}

O sítio arqueológico Limeira é um sítio a céu aberto que se localiza no município de Guarapari, região centro-sul do Estado do Espírito Santo, que possui latitude 20³7'30" - 2045'S e longitude 40³0' - 40²2'30"W (UTM 24K 341411 - 7714533), e ocupa uma área de $592,23 \mathrm{~km}^{2}$ (IBGE) (Fig. 2.2). De acordo com o Censo IBGE realizado em 2010, Guarapari possui 105.256 habitantes (IBGE, 2013).

Considerando-se em nível local, o sítio está inserido na porção sudeste do município, no bairro Camurugi, que se situa na zona urbana e é um dos menos populosos, com aproximadamente 3000 moradores, conforme o relatório do Plano Local de Habitação de Interesse Social (PLHIS) da Prefeitura Municipal de Guarapari realizado em 2012.

Segundo o PLHIS, a maioria de domicílios do bairro Camurugi não possui sistema de tratamento de esgoto e muitas áreas não fazem parte da rede do sistema de coleta de resíduos. Além disso, os moradores do bairro enfrentam problemas em relação ao transporte público, iluminação, limpeza e segurança.

Há também muitos casos de aglomeração de famílias (quando mais de uma família coabitam em um mesmo domicílio), alagamentos nas casas situadas nas áreas mais baixas e perigo de deslizamentos de terra sobre habitações construídas em encostas.

O sítio Limeira está localizado em região estuarina altamente impactada às margens da baía de Guarapari (Fig. 2.3), onde, ainda de acordo com os dados fornecidos pelo relatório do PLHIS (PMG, 2012), houve grande aumento do número de domicílios nos últimos 10 anos.

Nas proximidades do sítio arqueológico foi construída uma torre de distribuição de energia elétrica pela empresa EDP - ESCELSA. Dessa forma, o sítio Limeira sofreu muitas alterações, não somente pela construção da torre, mas também pela ação dos moradores da região de entorno, com o despejo de resíduos e de animais mortos. 


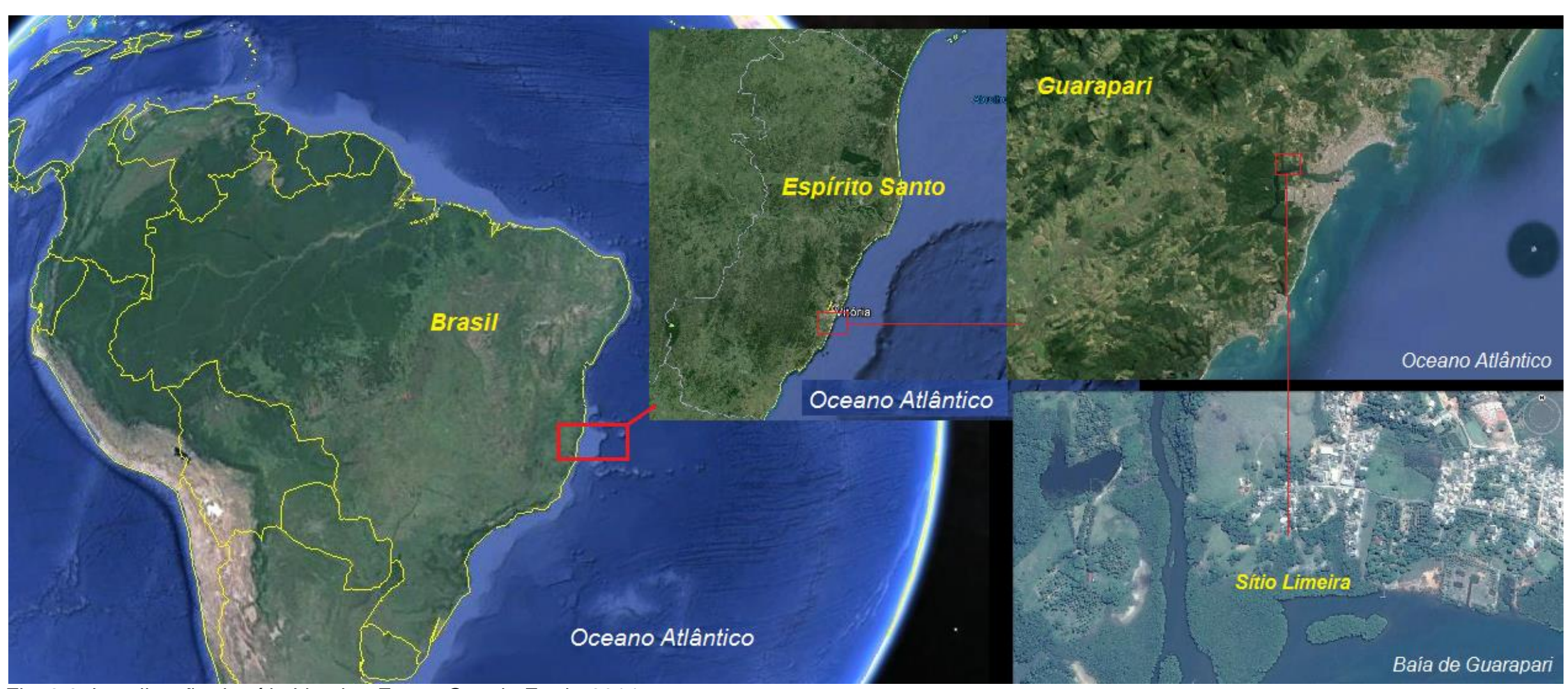

Fig. 2.2: Localização do sítio Limeira. Fonte: Google Earth, 2014. 


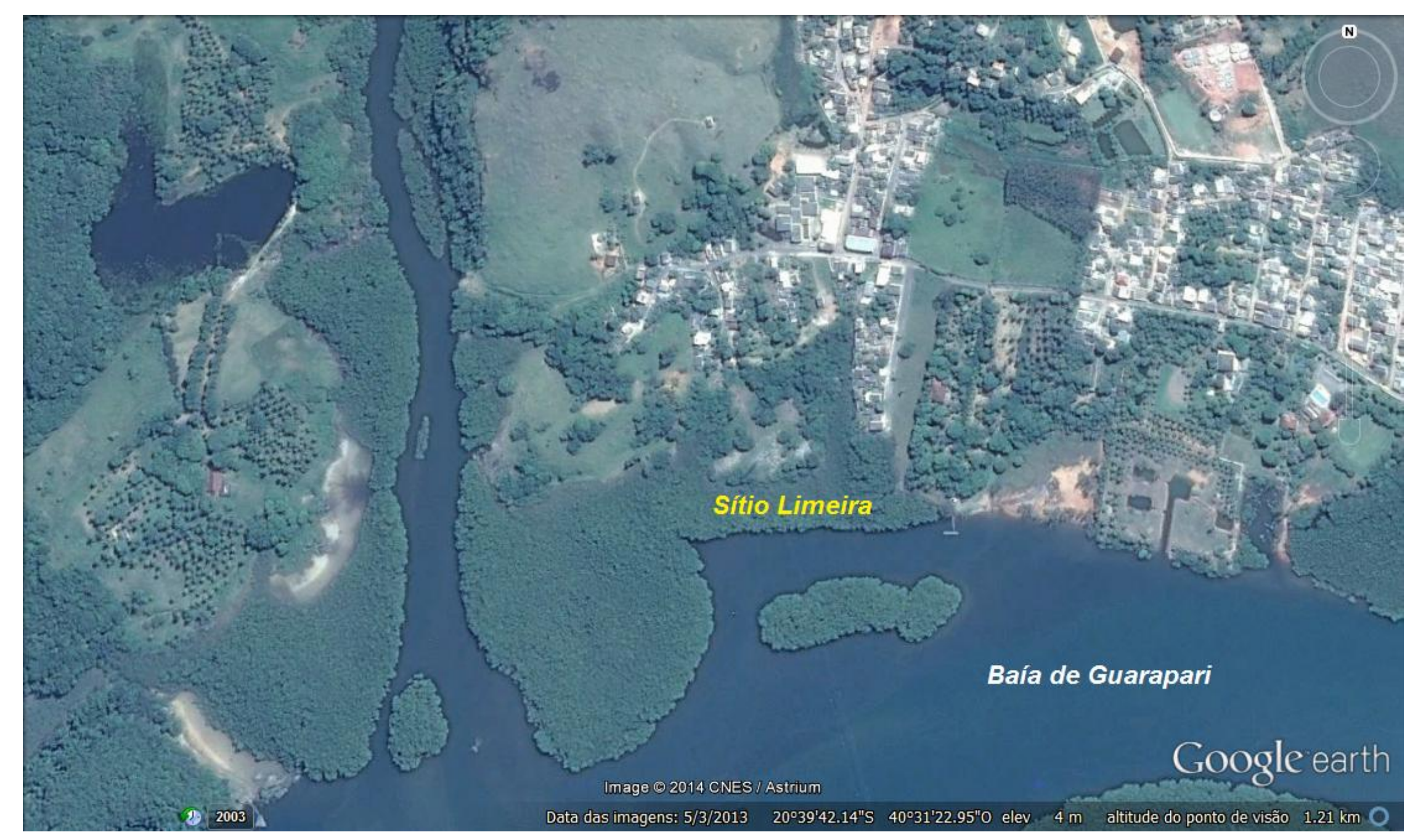

Fig. 2.3: Inserção do sítio Limeira. Fonte: Google Earth, 2014. 
Em relação às características ambientais atuais da região onde se insere o sítio Limeira observadas ao longo deste capítulo, é importante observar que, apesar de todos os impactos antrópicos citados, a apenas $4 \mathrm{~km}$ de distância do sítio encontrase a Reserva Estadual de Desenvolvimento Sustentável (RDS) Concha D'Ostra ${ }^{19}$, que também está localizada às margens da Baía de Guarapari. Essa unidade de conservação possui 953,5 hec de área composta por manguezal e fragmentos de Mata Atlântica de Tabuleiro, com milhares de espécies de animais e vegetais (SEAMA, 2014).

As características ambientais preservadas na Reserva Concha D'Ostra refletem as possibilidades ecológicas relacionadas a todos os aspectos que envolvem a interação entre Homem e natureza que deveriam existir na região onde se insere 0 sítio Limeira.

A disposição atual de recursos naturais como água doce, além de fauna marinha e estuarina - mesmo com todos os efeitos de impacto ambiental provocados pela colonização e pela urbanização - podem demostrar, mesmo de maneira superficial, a situação de subsistência das pessoas que habitavam essa região à época de ocupação do sítio.

A grande diversidade faunística, florística e a disposição de água potável oferecidos pelo bioma Mata Atlântica e pelo próprio mar provavelmente ofereciam a esses habitantes um diverso sistema de exploração e interação com meio ambiente, criando e modificando paisagens.

\subsection{2: Sedimentação:}

De acordo com os dados reunidos, o processo de sedimentação na região de Guarapari, onde se encontra o sítio Limeira, teve início no período Holoceno. Isso ocorreu através do intemperismo de rochas sedimentares ígneas da Formação Barreiras, principalmente devido a alterações climáticas que aumentaram o regime de chuvas e o aporte sedimentar na região há cerca de 7000 anos AP. De forma não menos importante, a formação do solo nessa região também teve como

\footnotetext{
${ }^{19}$ Essa RDS foi criada em 2003 e é gerenciada pelo Instituto Estadual do Meio Ambiente (IEMA) aparada pela Lei Estadual no 8464 de março de 2007, cujo objetivo é a proteção do ecossistema aliada ao uso sustentável dos recursos naturais pela população tradicional residente.
} 
contribuintes os sedimentos fluviais e marinhos, que se deslocaram sob influência de variações do nível do mar que ocorreram a essa mesma época.

O solo do sítio Limeira é caracterizado por apresentar sedimento areno-argiloso, porém, com baixo teor de argila. É importante observar que um solo com essas características possui baixa compactação, ou seja, suas camadas podem sofrer perturbações com facilidade, já que por seus grãos serem mais grossos oferecem maior espaçamento entre si devido à evidenciação das deformidades de sua superfície.

Além disso, devido à proximidade com o manguezal, apesar de não haver alto teor de argila, o solo possui certa quantidade de matéria orgânica. Dessa forma, tais características propiciam que não somente raízes de plantas possam se desenvolver com facilidade (conforme pôde ser observado), mas também que a água e outras substâncias líquidas possam percorrer livremente entre as camadas estratigráficas, tanto conforme a gravidade, como a água da chuva, como em sentido contrário, no caso da água proveniente da elevação da maré.

Além dos fatores já mencionados, foram observados muitos formigueiros. Não foi possível classificar quais espécies de formigas habitam a região do sítio Limeira, mas pelo fato de a camada arqueológica encontrar-se em baixa profundidade (30 a $50 \mathrm{~cm}$ ), esta pode facilmente sofrer perturbações decorrentes dessa origem biológica.

Em adição, por se tratar de um ambiente localizado em zona urbana, muitos moradores utilizam-se dele para colocar seus animais de estimação (cavalos, cabras, etc.) para alimentarem-se da vegetação presente ou para depósito de animais mortos - foram encontrados vários ossos de espécimes caninos e até mesmo bovinos. Toda essa movimentação também pode gerar perturbações no solo.

\subsubsection{Sítio Limeira - ambientação:}

Utilizando-se os dados expostos neste capítulo e correlacionando-os com 0 resultado da datação, é possível realizar uma breve caracterização do ambiente do sítio Limeira à sua época de ocupação e realizar algumas interpretações sobre o modo de vida de seus habitantes e sua interação com o meio ambiente. 
Sabe-se que não somente a ação humana é responsável por transformações significativas na paisagem, mas também mudanças climáticas e ambientais. Conforme detalhado anteriormente, na Reserva Biológica de Sooretama (1859'16" S e 406'28" O), localizada na região norte do Estado do Espírito Santo e a cerca de $180 \mathrm{~km}$ do sítio Limeira, a partir de 4000 anos AP as características climáticas já se apresentavam semelhantes às atuais.

Devido à pouca distância entre a Reserva Biológica de Sooretama e o sítio Limeira, e ao fato de essa unidade de conservação estar localizada em região próxima ao litoral, sobre Tabuleiros Costeiros (assim como o está o sítio Limeira) pode-se considerar que esses dois locais apresentavam (e apresentam) basicamente os mesmos padrões climáticos.

O sítio Limeira foi datado em $670 \pm 65$ AP (C14 - CENA-USP); dessa forma, os dados expostos indicam que havia a predominância de clima tropical chuvoso, com temperatura média anual elevada e alta umidade. Os ventos alísios de nordeste, predominantes na região, provavelmente já formavam a corrente Tropical Atlântica, que transporta calor desde o Equador em direção ao Trópico de Capricórnio.

Durante o inverno, a exemplo do que ocorria na Reserva Biológica de Sooretama, deveria haver diminuição na umidade relativa do ar, com a diminuição no nível de precipitações. A área provavelmente já recebia influência de ventos mais frios, os ventos sul e sudeste, acompanhados pelo sistema de correntes Polar Atlântico ( $\mathrm{Pa})$ com águas mais frias. Porém, de acordo com Pessenda (2012), a 2200 AP as lagunas e estuários já se apresentavam como no presente, ou seja, à época de sua ocupação, o sítio Limeira estava cercado pelas árvores do manguezal, que formam uma barreira natural contra os ventos marítimos. Além disso, a proximidade com as águas da Baía de Guarapari ajudavam a elevar as taxas de umidade relativa do ar, e consequentemente, a sensação térmica corporal.

Com os padrões climáticos expostos e considerando a posição geográfica do sítio Limeira, pode-se concluir que o mesmo estava inserido no bioma Mata Atlântica, entre os ambientes de restinga e de manguezal, assim como atualmente, porém, obviamente, esses ambientes haviam sofrido menos impacto antrópico.

Dessa forma, é possível sugerir que no sítio Limeira havia a presença de arbustos, herbáceas e árvores de pequeno porte (frutíferas ou não). Além disso, sua fauna deveria ser composta por aves, répteis, pequenos mamíferos e insetos. Já os manguezais já apresentavam suas típicas árvores de pequeno porte (não frutíferas e 
altamente adaptadas a esse ambiente) e espécimes animais como aves, peixes de todos os tamanhos, camarões, caranguejos e moluscos. A riqueza e diversidade de espécimes animais e vegetais que compõem a já citada Reserva Estadual de Desenvolvimento Sustentável (RDS) Concha D'Ostra (localizada a apenas 4km do sítio Limeira), é um forte indício da probabilidade de essa afirmativa ser verdadeira.

Devido ao fato de estar inserido em área protegida por manguezal que margeia uma baía, o sítio Limeira não recebia impacto direto de ondas, situando-se em região de micromaré, cuja amplitude não excede os $2 \mathrm{~m}$, e apresentando topografia bastante suave, com ponto mais elevado aos $2 \mathrm{~m}$ de altitude.

Em área adjacente ao sítio Limeira, seguindo a linha de costa a menos de $1 \mathrm{~km}$ de distância, há a presença de dois costões rochosos constituídos de rocha sedimentar granítica, apresentando veios de quartzo, onde atualmente podem ser encontrados moluscos bivalves das espécies: Arca imbricata, Crassostrea rhizophorae, Lucina pectinata, Lunarca ovalis, Iphigenia brasiliana e Anomalocardia brasiliana. Também nesses locais é possível encontrar os moluscos gastrópodes das espécies: Cymatium parthenopeum e Stramonita haemastoma.

A foto 2.1 representa um dos costões rochosos localizados nas imediações do sítio Limeira e a figura 2.4 a sua localização.

A baía de Guarapari, que margeia o sítio Limeira, é um ambiente estuarino, ou seja, um local onde há o encontro entre a água doce do rio e a água salgada do mar. Por essa razão, a água localizada nas proximidades do sítio Limeira não é potável, havendo a necessidade de direcionar-se mais à montante do rio mais próximo para conseguir de água própria para o consumo.

De acordo com os dados hidrográficos, o rio Jabuti é o corpo d'água mais próximo ao sítio Limeira. Isso sugere a possibilidade de esta ser a principal fonte de água potável para os habitantes do local (ANEXO D). Porém atualmente é provável que as características do rio Jabuti não sejam mais as mesmas que há cerca de 670 anos, em decorrência das ações antrópicas sofridas em período recente, como possíveis alterações do curso para atender às propriedades rurais localizadas em suas imediações e redução do volume de água promovido por seu represamento.

O represamento das águas do rio Jabuti foi realizado pela Companhia Espírito Santense de Saneamento (CESAN) na Estação Elevatória de Água Bruta de Jaboti, localizada a cerca de $3,5 \mathrm{~km}$ do sítio Limeira, onde são extraídos 600 litros de água por segundo (CESAN, 2013). Tais dados podem ser observados na figura 2.5 . 
À época de ocupação do sítio Limeira não havia o represamento da água do rio nem as outras interferências antrópicas já citadas. Dessa forma, é provável que os habitantes do sítio Limeira caminhassem ainda menos para a obtenção desse recurso.

Todas as características acima descritas revelam um ambiente propício para a subsistência de populações pertencentes a uma sociedade caçadora-coletorapescadora que viviam em acampamento a céu aberto. 


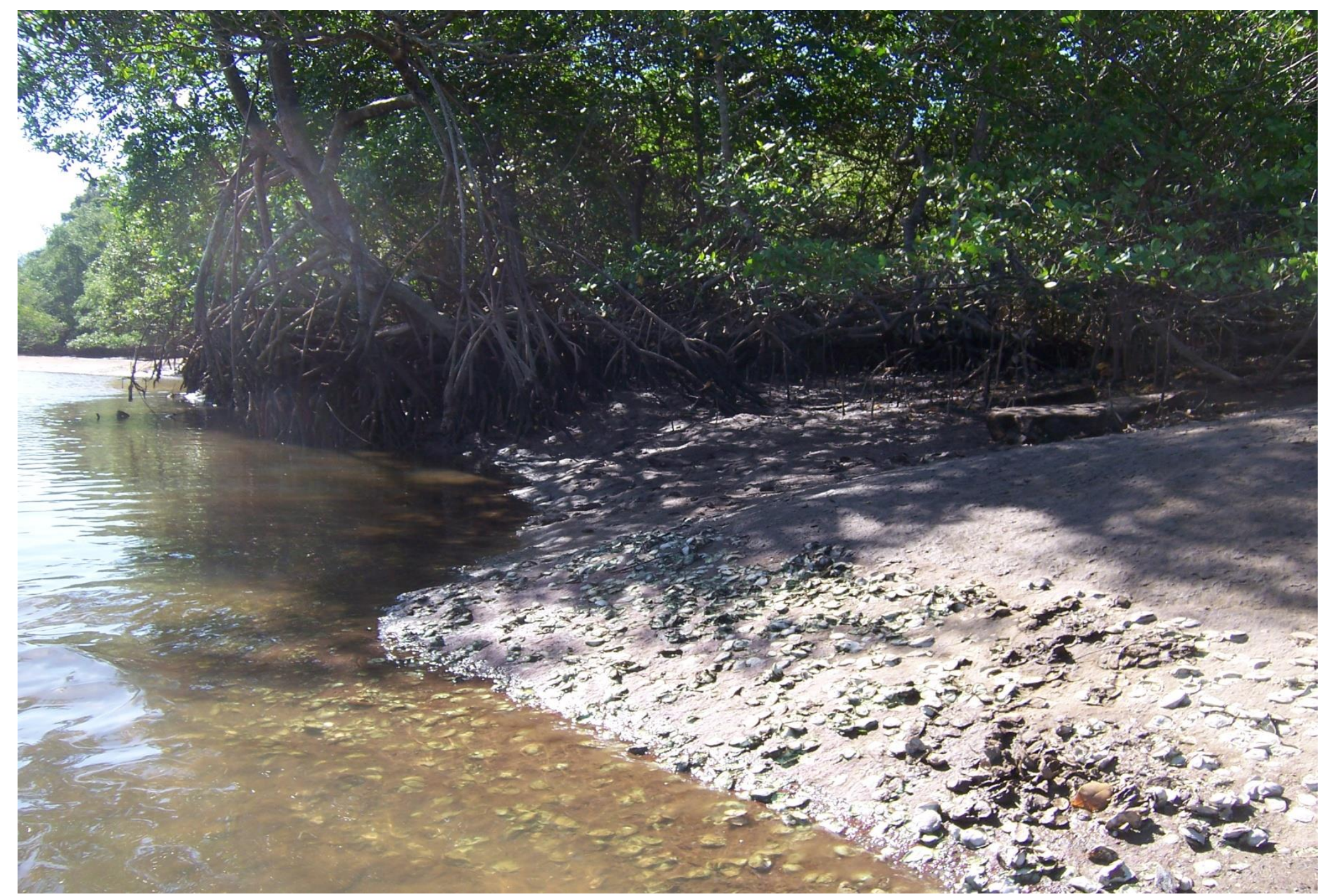

Foto 2.1: Costão rochoso com moluscos associados. Foto: Maria Ester Franklin. Mai/2013. 


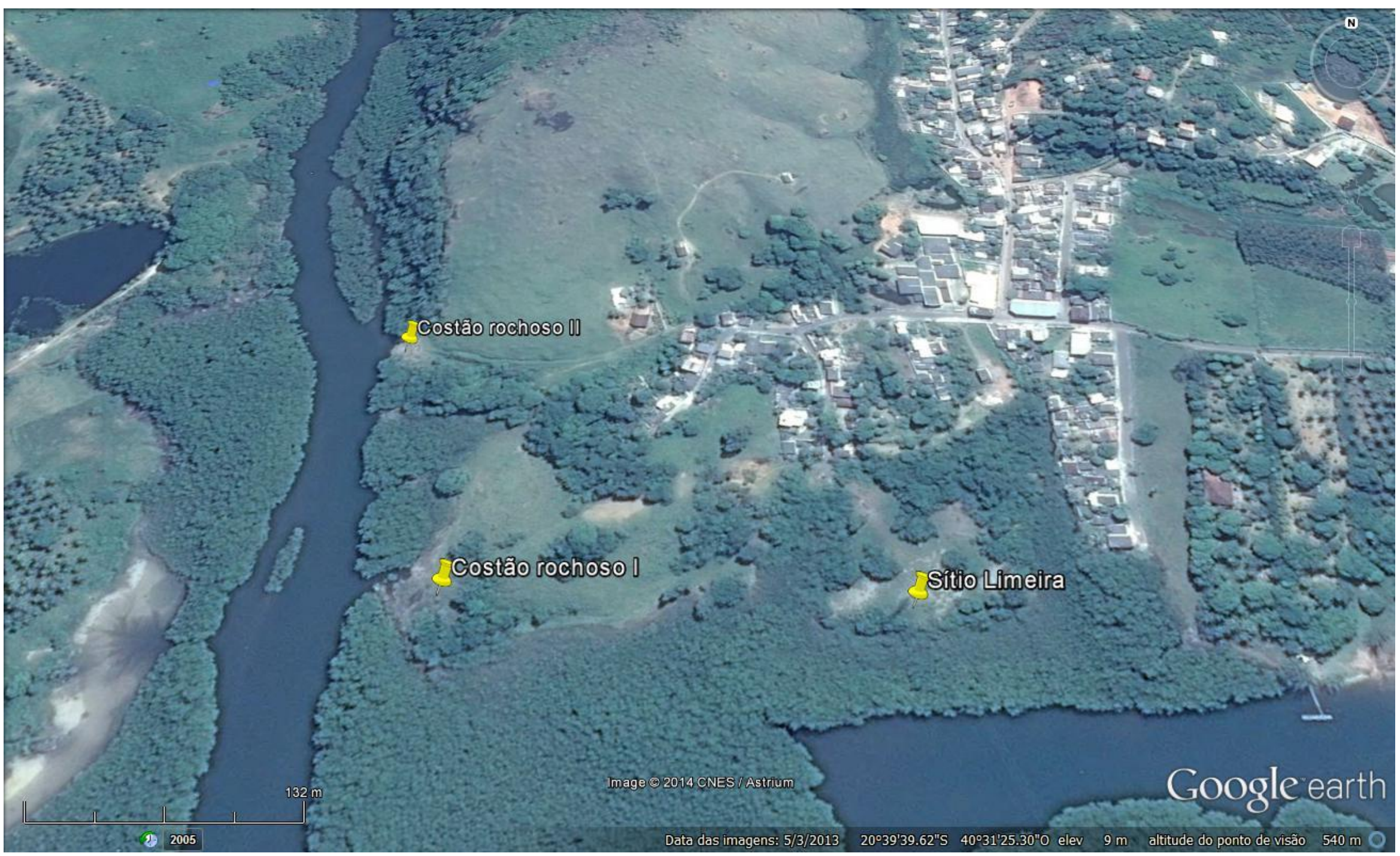

Fig.2.4: Localização dos costões rochosos observados em relação ao sítio Limeira. Fonte: Google Earth, 2014. 


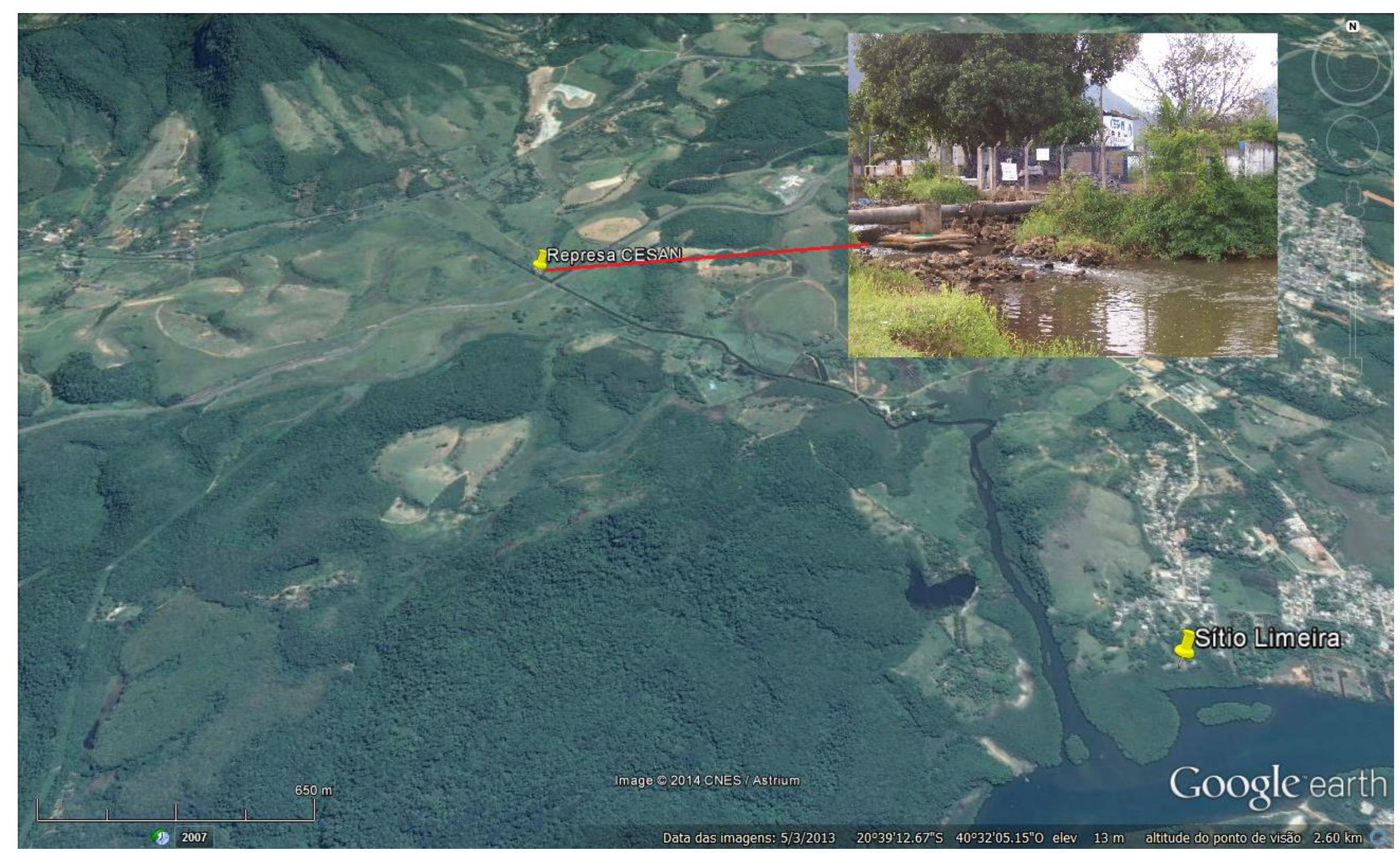

Fig. 2.5: Localização da represa sobre o rio Jabuti. Em destaque, foto da represa. Fonte: Google Earth, 2014. Foto: Maria Ester Franklin, mai/2013. 


\section{Capítulo 3}

\section{Pesquisas arqueológicas: estratigrafia, estruturas e datação}

\subsection{MÉTODOS E TÉCNICAS EMPREGADOS NAS PESQUISAS DE CAMPO:}

Para realização da pesquisa intensiva de campo buscou-se a construção de um sólido embasamento metodológico e técnico, com o emprego do conceito Totalidade Social de Mauss (1974b), do método de pesquisa de campo por superfícies amplas associado à técnica de decapagem por camadas naturais de Leroi-Gourhan (1950; 1964) adaptados às características do solo brasileiro por Pallestrini (PALLESTRINI \& PERASSO, 1984; ALVES, 2009) e de procedimentos de investigação em arqueologia da paisagem propostos por Morais (2012).

Com base em Morais (2011), o método adotado para a realização da pesquisa envolveu etapas de gabinete, preparação, levantamentos, prospecção e escavação. Para a evidenciação do empírico no sítio Limeira, foi realizada uma análise detalhada, considerando desde solos arqueológicos e cultura material até sua inserção na paisagem. Além disso, houve a preocupação em considerar o Fator Geo, definido por Morais (2011) como as contribuições da Geografia, Geomorfologia e Geologia para a Arqueologia.

\subsection{O RESGATE ARQUEOLÓGICO:}

Sabe-se que nos dias de hoje a Arqueologia vem sendo cada vez mais solicitada em cumprimento da Legislação Ambiental Brasileira que envolve resgate arqueológico, definido na Resolução 001, de 23 de janeiro de 1986 (BRASIL, 2013), onde há as definições, responsabilidades, critérios básicos e diretrizes gerais para uso e implementação da avaliação de impacto ambiental como instrumento da PNMA (Política Nacional de Meio Ambiente).

O Art 6ำ - EIA (Estudo de Impacto Ambiental), demonstra a importância de diagnóstico ambiental da área de influência, descrição e análise dos recursos 
ambientais e suas interações, exigindo caracterizar a situação ambiental da área (meios físico e biótico, ecossistemas naturais e meio sócio econômico).

Conforme Morais (2011), em aplicação à Arqueologia, entende-se como meio sócio econômico o uso e ocupação do solo, usos da água e sócio-economia destacando sítios arqueológicos, históricos e culturais da comunidade, relações de dependência sociedade local x recursos ambientais e potencial utilização futura dos mesmos.

Nesse sentido, em cumprimento da lei, o empreendedor é responsável por obter meios de elaboração de programas de mitigação dos impactos ambientais negativos, o que engloba a obrigatoriedade do salvamento arqueológico. Além disso, segundo a Resolução 006 de 16 de setembro de 1987, deve-se haver licenciamento ambiental para obras de grande porte (BRASIL, 2013).

Diante disso, vale destacar a importância da Arqueologia de salvamento via contrato com empresas e o fato de ser fundamental que suas atividades sejam bem realizadas, de acordo com Bezerra de Meneses (1988), que expressou que a Arqueologia de salvamento é significativa: "nenhuma distinção deve ser feita no nível da substância entre pesquisa rotineira ou de salvamento."

Porém, uma problemática bastante abordada atualmente é o fato de, em muitos casos, na Arqueologia de salvamento ser inviável (ou simplesmente são ser considerada) a realização das atividades de maneira ideal. Segundo Morais (2011), a sistemática metodológica muitas vezes é carente de consolidação, tem-se visado apenas o aspecto quantitativo (sítios e material arqueológico), várias estruturas arqueológicas conexas são consideradas individualmente, como nos casos clássicos de sítio-habitação e os contextos vertical e/ou horizontal são ignorados na coleta.

Não é novidade expressar que na maioria das vezes no resgate arqueológico é impossível aplicar-se os mesmos métodos realizados em pesquisas rotineiras ou acadêmicas devido ao tempo e/ou recursos reduzidos ou ainda a uma série de outros fatores.

Diante disso, optou-se por utilizar-se dos dados coletados em campo por Perota e equipe durante as pesquisas de resgate arqueológico, mas também pela realização de pesquisa intensiva empírica de campo, a fim de que fossem fornecidos subsídios a mais como garantia de realização de um trabalho meticuloso e contundente. 
No total então, foram realizadas 4 etapas de pesquisa de campo no sítio Limeira: uma relacionada ao resgate arqueológico por contrato realizada por Celso Perota e equipe em 2009 (PEROTA, 2010) e três de cunho acadêmico destinadas a esta pesquisa de Mestrado, ocorridas nos meses setembro e dezembro de 2012 e maio de 2013.

\subsection{1 $1^{\text {a }}$ pesquisa de campo - resgate arqueológico via contrato (2009):}

Conforme expressado anteriormente, o sítio Limeira foi alvo de resgate arqueológico por contrato devido à implantação de uma linha de distribuição de energia elétrica (LD) pela empresa EDP-ESCELSA, a "LD 138kV Ramal para SD Lameirão" no município de Guarapari, Estado do Espírito Santo. A etapa de resgate arqueológico foi realizada por Celso Perota e equipe em 2009, e o relatório dessas atividades (Perota, 2010) entregue ao IPHAN do Espírito Santo foi utilizado como base para as informações descritas.

De acordo com Perota (2010), a LD inicia-se na estrutura 6/2 da LD 138kV Cachoeiro - Vitória II, na localidade de São João de Jabutí, próxima à rodovia BR101 e termina na futura Subestação Lameirão, localizada no bairro Olaria, município de Guarapari.

Percorrendo, em quase sua totalidade, áreas rurais como as localidades de Camurugí e Payssandú, bairros de Guarapari, o objetivo da EDP-Escelsa foi interligar a nova subestação à LD 138kV Cachoeiro-Vitória II, permitindo a transferência de uma maior potência de energia elétrica para a cidade Guarapari e, consequentemente, suprindo a demanda por energia elétrica da região.

Com autorização para dar início às atividades de campo publicada no Diário Oficial da União de 03 de julho de 2009, Celso Perota e equipe realizaram uma série de atividades visando o bom relacionamento entre a equipe de arqueologia e membros da empresa contratada para realização da construção da linha de distribuição, enfocando questões de saúde, meio ambiente e segurança. Importante frisar que à época do resgate arqueológico as torres de distribuição de energia já haviam sido construídas e energizadas.

Após o treinamento e devidas autorizações, a equipe de arqueólogos (Celso Perota e Henrique Valadares) e colaboradores juntaram-se aos técnicos da empresa 
contratada e, através de prospecções, reconheceram dois sítios arqueológicos, Limeira e Colina. Porém, um deles, o Colina, já se encontrava altamente impactado provavelmente por erosão provocada pelas intensas chuvas que precipitaram durante os meses de outubro e novembro de 2009. De acordo com Perota (2010), como o sítio Colina apresentava camada arqueológica pouco espessa, quase nada havia restado para ser resgatado.

Resumidamente, para os dois sítios foram adotadas as seguintes etapas:

- Escavação;

- Análise laboratorial do material arqueológico;

- Contextualização dos dados levantados;

- Ocorrência de outras evidências;

- Curadoria do material arqueológico.

Como já expressado, todas as etapas foram adotadas para os dois sítios arqueológicos, porém, o enfoque foi dado às atividades relacionadas ao sítio Limeira, objeto desta pesquisa de Mestrado.

Escavações no sítio Limeira:

Perota (2010) delimitou a área do sítio em um polígono com as seguintes coordenadas (Datum WGS64):

$$
\begin{aligned}
& 24 K 341357-7714560 \\
& 24 K 341352-7714490 \\
& 24 K 341430-7714564 \\
& 24 K 341427-7714531
\end{aligned}
$$

De acordo com a delimitação realizada por Perota e equipe, o sítio Limeira possui $2400 \mathrm{~m}^{2}$, onde foram identificadas duas áreas de ocupação a 10 metros da linha de marés médias. Dessa forma, foi decidido dividir a área do sítio em dois setores, denominados Setor 1 e Setor 2. 
No Setor 1 foi realizada escavação com medidas $2 \times 2$ metros utilizando-se níveis artificiais de $5 \mathrm{~cm}$ até atingir-se uma profundidade de $60 \mathrm{~cm}$, sem a ocorrência de evidências arqueológicas. À partir dessa profundidade, a equipe realizou sondagem com trado biarticulado (escavadeira) até que fosse atingida a profundidade de $1,20 \mathrm{~m}$, quando foi atingida a água, provavelmente em decorrência da proximidade do manguezal.

No Setor 2 foi realizada escavação com medida $1 \times 1$ metro. Assim como no Setor 1 , foi feita retirada de sedimento em níveis artificiais de $5 \mathrm{~cm}$ até que se atingisse a profundidade de $60 \mathrm{~cm}$, quando foi realizada sondagem com trado biarticulado até a profundidade de 1 metro, atingindo-se a água.

De acordo com Perota (2010), o perfil estratigráfico dos dois setores apresentou três camadas básicas: o Setor 1 apresentou solo arenoso (variando em sua coloração e na presença ou não de raízes) e restos malacológicos, além de evidências arqueológicas ${ }^{27}$. Já o Setor 2 apresentou solo areno-argiloso em uma de suas camadas, além de haver presença de material arqueológico. Tais características serão consideradas de forma mais aprofundada posteriormente, no item 3.4 deste mesmo capítulo ${ }^{28}$.

Com os resultados obtidos no Setor 2, Perota e equipe decidiram ampliar a área escavada em mais $1 \times 1$ metro, denominando a ampliação de Setor 3 , que apresentou a mesma estratigrafia do Setor 2.

\section{Análise Laboratorial:}

De acordo com Perota (2010), as evidências arqueológicas coletadas foram dos tipos líticas e malacológicas. A principal matéria prima utilizada para confecção dos artefatos líticos foi o quartzo leitoso e hialino, além de granito e basalto. Além do material lascado foram coletados seixos de quartzo e fragmentos de granito e basalto com vestígios de que foram utilizadas como base de fogueira, totalizando 797 peças.

Dentre o material malacológico coletado, foram identificados moluscos bivalves e gastrópodes das seguintes espécies:

\footnotetext{
27 Item 3.4, Quadro 3.1.

28 Item 3.4, Quadro 3.2.
} 
- Bivalves - Arca imbricata, Crassostrea rhizophorae, Lucina pectinata, e Anomalocardia brasiliana.

- Gastrópodes - Cymatium parthenopeum e Stramonita haemastoma.

Perota (2010) afirma que os dados obtidos em pesquisa realizada no sítio Limeira indicam que se trata de um sítio arqueológico pré-cerâmico pertencente à tradição Itaipu, recorrente no litoral dos Estados do Rio de Janeiro e Espírito Santo ${ }^{29}$. Perota caracterizou o sítio como a céu aberto, habitado à sua época de ocupação por população caçadora-coletora.

\subsection{CAMPANHAS DE PESQUISA ACADÊMICA:}

A pesquisa intensiva de campo de cunho acadêmico foi executada em três etapas: a primeira em setembro de 2012, a segunda em dezembro do mesmo ano, e a terceira em maio de 2013.

Os métodos adotados para a realização de todas as campanhas foram baseados no conceito Fato Social Total explanado por Marcel Mauss em sua obra "Ensaio sobre a dádiva" (1974a) e no método "Superfícies Amplas" com a técnica de "decapagens por camadas naturais" de André Leroi-Gourhan e adaptado ao solo brasileiro por Luciana Pallestrini (PALLESTRINI E PERASSO, 1984; ALVES, 2002; 2009), conforme já abordado.

Além disso, utilizou-se o método de investigação em arqueologia da paisagem explanado por Morais (2012), optando por uma abordagem em meso e micro-escala,

29 Tradição Itaipu - registrada por Ondemar Dias Júnior junto ao Programa Nacional de Pesquisas Arqueológicas (PRONAPA) em 1983, esta tradição é caracterizada pelo fato de os sítios arqueológicos apresentarem restos de carapaças de moluscos como os sambaquis, porém, diferindo destes devido ao predomínio de camadas sucessivas de estratos arenosos, com fogueiras e grande quantidade de artefatos líticos; em especial, lascas de quartzo. De acordo com o descrito por Dias Júnior e Carvalho (1983/84; 1995), as características que permeiam a Tradição Itaipu são: a riqueza em artefatos líticos lascados, a presença de indústria de osso e concha, com evidências alimentares variadas, restos malacológicos em quantidade não expressiva (em comparação aos sambaquis), predominado em faixa cronológica curta, sendo superada pelas atividades de caça, pesca e principalmente coleta (DIAS JÚNIOR, 1969; 1992 a e b). 
no qual o autor divide a análise de investigação da arqueologia da paisagem em 3 (três) estágios, sendo eles:

- Estágio 1 (básico) - "é o rastreamento preliminar do patrimônio arqueológico", considerando compartimentos paisagísticos, conjuntos urbanos, etc. Nesse estágio a unidade geográfica focada é o município, relacionando suas características ambientais, dados de arqueologia preventiva e gestão do patrimônio arqueológico.

Com relação aos procedimentos de campo, no estágio 1 é realizado o reconhecimento da paisagem sem intervenções, atentando-se aos compartimentos ambientais e seu potencial arqueológico, e, caso necessário, georreferenciamento, levantamento métrico-arquitetônico de edificações e registro de imagens.

- Estágio 2 (avaliação) - "trata-se da avaliação do patrimônio arqueológico", considerando os compartimentos paisagísticos e estruturas de interesse potencial para a arqueologia, com unidade geográfica pontual.

Em campo, esse estágio envolve o reconhecimento de terreno, sem intervenções, através de "observações espontâneas e induzidas, prospecção e sondagens aleatórias na matriz sedimentar, Caso necessário, deve-se realizar coletas comprobatórias semicontroladas.

- Estágio 3 (manejo) - "é a intervenção no patrimônio arqueológico", também considerando os compartimentos paisagísticos e estruturas de interesse potencial para a arqueologia. Nesse estágio, a unidade geográfica focada é o sítio arqueológico.

Os procedimentos de campos são constituídos de: prospecção e escavação arqueológica (sondagens ritmadas, cortes, trincheiras e decapagens), além de coleta controlada de vestígios arqueológicos com georreferenciamento tridimensional.

Como bibliografia básica para essa etapa, também foram utilizadas as referências:

- "Arqueología: método y técnicas em superfícies amplias" de Pallestrini e Perasso (1984), onde o método de escavação por superfícies amplas é explicado. De acordo com os autores, o objetivo de sua utilização é a obtenção de uma visão global do sítio arqueológico.

Assim, o método consiste na realização de uma limpeza prévia do sítio para retirada da vegetação afim de que os vestígios que estão na superfície possam ser 
evidenciados, quadriculamento do sítio, inserção e levantamento topográfico e georreferenciamento.

Após a etapa descrita, é possível saber qual o melhor local para a realização de perfis e trincheiras, para observar as características das diferentes camadas sedimentológicas do sítio e evidenciar o estrato arqueológico.

Apenas depois de cumpridas as etapas anteriores a(s) decapagem(s) pode $(\mathrm{m})$ ser realizada(s). Conforme Pallestrini e Perasso (1984), essa técnica corresponde a uma série de operações cuja finalidade é evidenciar o solo arqueológico da maneira mais completa possível, sempre utilizando instrumentos finos e delicados, como pá de tamanho pequeno e pincéis, e mantendo todos os vestígios evidenciados em seu local exato.

Somente após o devido mapeamento do sítio em nível tridimensional os vestígios podem ser coletados para posterior análise laboratorial o que permite uma visão ampla a respeito da cultura material e sua inserção no sítio arqueológico.

- "Interpretação das estruturas arqueológicas em sítios do Estado de São Paulo" de Pallestrini (1975), no qual a autora, através da pesquisa em sítios arqueológicos, demonstra a aplicação do método de escavação por superfícies amplas.

- "Ensaios de Arqueologia Brasileira - vol I" de Pallestrini e colaboradores (1982), no qual é apresentado o método de representação de plantas baixas de uma escavação arqueológica, além de técnicas de recuperação de vestígios arqueológicos em campo.

- "Arqueologia pré-histórica brasileira" de Pallestrini e Morais (1982), no qual os autores expõem resumidamente informações essenciais sobre a arqueologia préhistórica brasileira, abordando desde o que é um sítio pré-histórico, incluindo métodos de pesquisa de campo e de análise de vestígios a explicações a respeito dos diferentes métodos de datação.

O desenvolvimento das etapas de pesquisa de campo de cunho acadêmico serão descritas detalhadamente a seguir:

\subsubsection{1 $1^{\text {a }}$ Campanha - setembro 2012:}

Antes de dar início a qualquer atividade relacionada à pesquisa intensiva de campo, foi reunida a equipe de trabalho para apresentação e esclarecimentos a 
respeito da natureza do projeto, objetivos, métodos a serem utilizados, necessidade de uso de equipamentos de segurança, etc.

Além disso, com base no Estágio 1 de investigação em arqueologia da paisagem proposto por Morais (2012), foi exposto um breve histórico da região e reconhecimento de território, realizando-se consultas cartográficas e caminhadas na cidade destacando-se a região onde se localiza o sítio Limeira e considerando o potencial arqueológico e paisagístico de cada local. Além disso foram feitos os preparos, reparos e aquisição de todo o material que seria utilizado em campo bem como a organização da logística.

Após preparação da equipe, foram realizados levantamentos, nos quais houve reconhecimento de área através de prospecções ao longo da área do sítio arqueológico e região de entorno comparando-se o que é observado aos dados gerados durante as pesquisas de resgate arqueológico realizadas previamente, conforme o relatório já exposto.

Em adição, foi feito junto aos habitantes da região de entorno do sítio, um trabalho de esclarecimento das atividades a serem desenvolvidas e entrevistas com os moradores mais antigos para coleta de informações sobre uso e ocupação recentes na área do sítio arqueológico, bem como de dados sobre como se deu a construção da torre de distribuição de energia elétrica.

Somente após o término da etapa acima descrita, iniciou-se o Estágio 2 da pesquisa (MORAIS, 2012) no qual a equipe realizou levantamento prospectivo ao longo do sítio, com realização de limpeza de algumas áreas para evidenciação do registro arqueológico.

Além disso, foram realizadas medidas de área com auxílio de trena, determinação do Ponto 0 (P0) e georreferenciamento com auxílio de aparelho GPS, sendo as coordenadas de PO:

2039'42,61"S

4031'20,62"O

O ponto PO localiza-se no centro da torre de transmissão de energia elétrica, e é o local onde é registrada a maior altitude em toda a área do sítio arqueológico $(2 \mathrm{~m})$, talvez apresentando-se assim devido até mesmo aos certos aterramentos para garantia de sustentação das bases da estrutura. 
Também foram realizadas coletas de superfície ao longo da área do sítio e sondagens aleatórias de verificação na matriz sedimentar, de $30 \mathrm{~cm}^{2}$ cada com profundidades variando entre 70 e $120 \mathrm{~cm}$ como tentativa de encontrar o melhor local para realização de trincheira.

Ao todo foram 19 pontos de sondagem ao longo de uma área de aproximadamente $1000 \mathrm{~m}^{2}$ porém, raros foram os pontos nos quais conseguiu-se encontrar vestígios arqueológicos (S10 e S18). As escavações dos pontos de sondagem foram interrompidas ao se encontrar muita água (S7, S8, S12, S13) ou rocha sedimentar (S1, S2, S3, S4, S5, S6, S9, S10, S11, S14, S15, S16, S17, S18, S19).

Durante essa etapa confirmou-se os dados pedológicos expostos por Perota, ou seja, o solo apresentou-se arenoso, com alta concentração de matéria orgânica, o que provavelmente é decorrente do fato de o local onde está situado o sítio Limeira se tratar de ambiente estuarino. Dessa maneira, é interessante notar que não foram detectados níveis estratigráficos bem delimitados. Para isso, seria necessário a escavação de trincheiras extensas, o que não foi feito devido a dúvidas quanto ao melhor ponto para fazê-lo. Porém, essa etapa foi realizada na $2^{\underline{a}}$ campanha de escavação. A etapa avaliação do patrimônio arqueológico do sítio Limeira durou 4 (quatro) dias úteis.

Durante essa etapa, foram detectadas estruturas de fornos em ruínas dentro da área de manguezal, o que tomou certo tempo para limpeza e caracterização. Sabese que trata-se de um projeto cujo fulcro é o período pré-contato, mas viu-se a necessidade de ao menos localizar e caracterizar essas estruturas mesmo que grosseiramente, pois são o registro material de uso e ocupação do local onde se situa o sítio Limeira.

Mesmo sem uma estratigrafia bem delimitada, foi decidido realizar intervenções, o que foi feito no local onde foi encontrada a maior quantidade de vestígios arqueológicos em superfície pela equipe, os pontos $S_{10}$, próximo à torre de distribuição de energia, e $S_{18}$, ao lado dos Setores 2 e 3 escavados durante a já referida campanha de resgate arqueológico realizada por Perota (2010), tomando-se cuidado para não intervir no mesmo local. Os pontos $\mathrm{P} 0$, de sondagem e decapagem estão representados na figura 3.1.

$\mathrm{Na}$ última etapa de campo foi realizada a intervenção arqueológica, que abrangeu o período de 10 a 15 de setembro, ou seja, 4 (quatro) dias úteis e sábado até as 
Sítio arqueológico Limeira - Guarapari/ES

$1^{a}$ Campanha acadêmica de escavação - set/2012

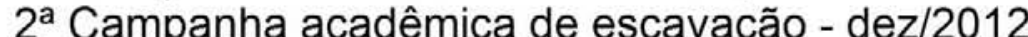

$3^{\text {a }}$ Campanha acadêmica de escavação - dez/2012

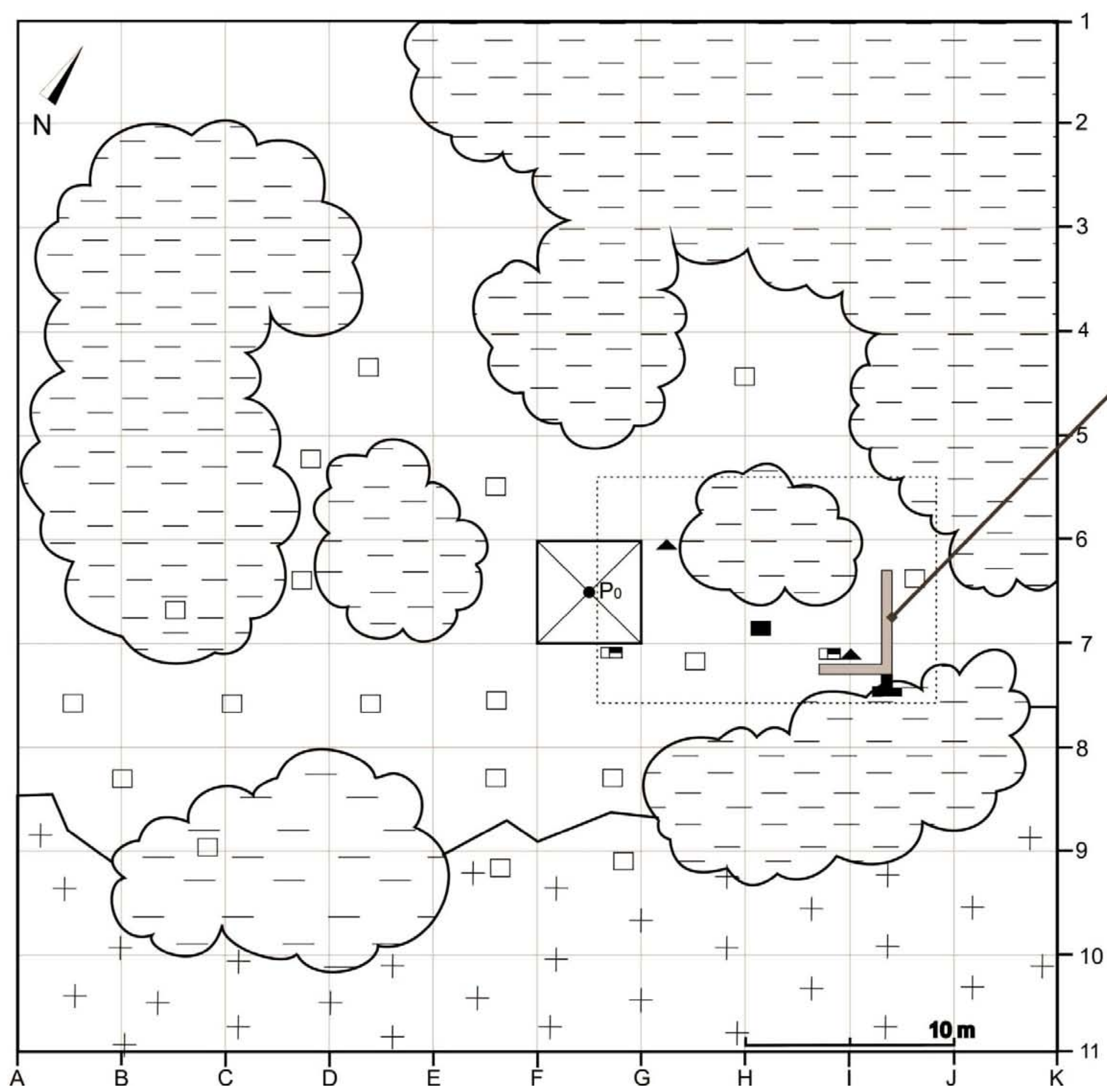

Fig. 3.1: Planta baixa do sítio Limeira - Guarapari/ES.

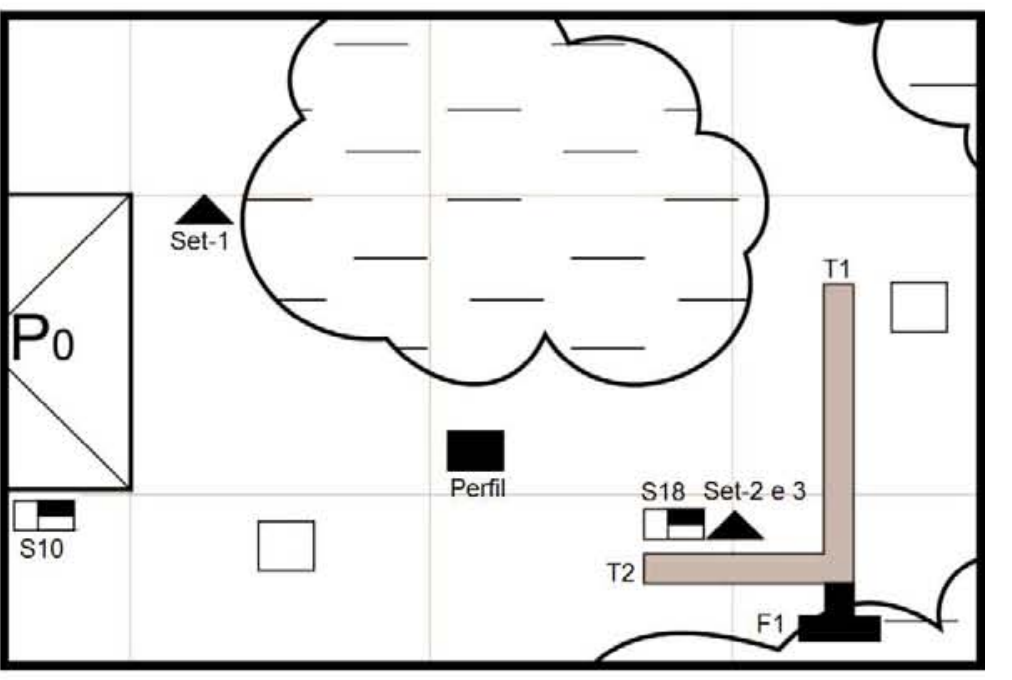

Legenda:

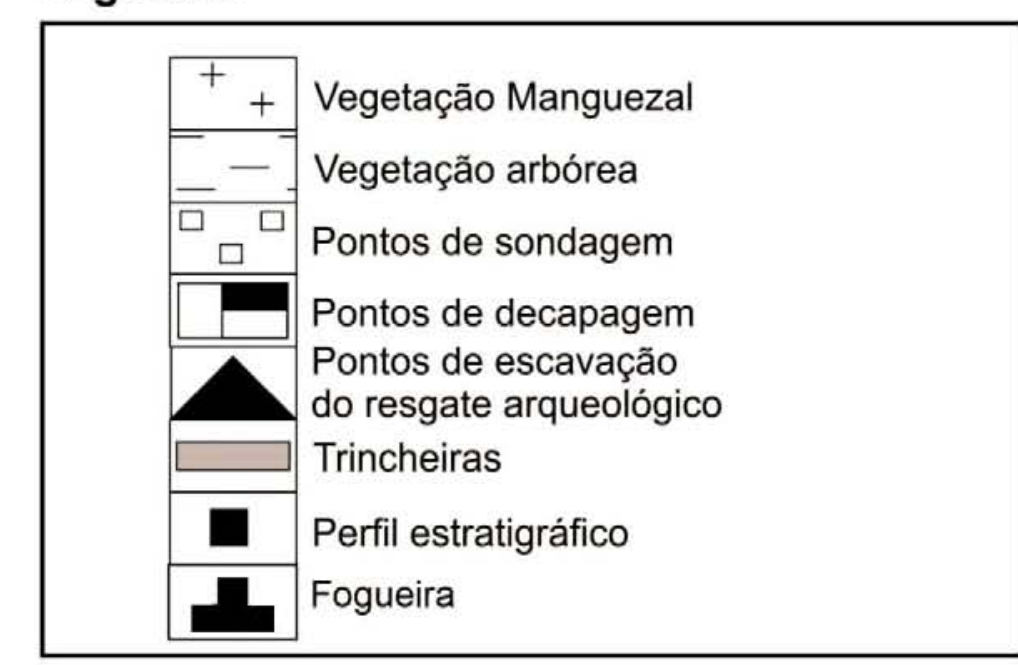

$\mathrm{P}_{0}-20^{\circ} 30^{\prime} 42,61^{\prime \prime S}$ $40^{\circ} 31 ' 20,62 " \mathrm{O}$
Org: Maria Ester Franklin Des: Mariana Franklim 
12hrs. Nos primeiros 2 dias foi realizado o aumento da área de limpeza e iniciou-se - Estágio 3 proposto por Morais (2012), com intervenção do patrimônio arqueológico. O processo se deu através da escavação dos pontos cujas coordenadas são:

$$
\begin{aligned}
& \text { S18 - 20 } 39^{\prime} 41,45^{\prime \prime S} \text { e } 40^{\circ} 31^{\prime} 18,8^{\prime \prime O} \\
& \text { S10 - 20 } 39^{\prime} 41,4^{\prime \prime S} \text { e } 40^{\circ} 31^{\prime} 20,9^{\prime \prime O}
\end{aligned}
$$

Devido ao tempo limitado, optou-se por realizar decapagem em área $2 \times 1$ metros. Em $S_{18}$, o trabalhador braçal, utilizando-se de enxada, removeu o sedimento da área até a profundidade de $40 \mathrm{~cm}$. À partir desse ponto a equipe tomou à frente e iniciou a decapagem por camadas naturais. Todo sedimento retirado durante as etapas de decapagem e sondagem foram devidamente peneirados (Fig. 3.2 - Foto 01). Os poucos vestígios arqueológicos encontrados foram coletados em peneira sendo depositados em sacos plásticos e devidamente etiquetados (com os dados: nome do sítio, ponto, profundidade e tipo de material).

Praticamente não foram encontrados vestígios arqueológicos, apenas uma concha (insitu) localizada a $50 \mathrm{~cm}$ de profundidade e alguns fragmentos líticos coletados na etapa de peneiramento. Nesse ponto foi atingida a profundidade de $130 \mathrm{~cm}$, quando foi evidenciada a rocha sedimentar.

Em S10 foi evidenciada uma pequena concentração de conchas e fragmentos líticos entre 20 e $23 \mathrm{~cm}$ de profundidade. Outros fragmentos líticos foram encontrados na etapa de peneiramento. Nesse ponto foi atingida a profundidade de $120 \mathrm{~cm}$, quando também foi encontrada a base de rocha sedimentar.

Após as decapagens, os pontos foram novamente enterrados com seu sedimento original para que fossem evitados acidentes (Fig. 3.2 - Foto 02).

Sempre ao chegar ao local de alojamento da equipe, o material coletado era depositado em ambiente ventilado e protegido com os sacos abertos para eliminação da umidade. Após cerca de 24 horas os sacos eram fechados e colocados cuidadosamente em caixas de papelão. Após encerradas as atividades de campo os vestígios arqueológicos foram depositados no local de guarda do material, ou seja, no Laboratório de Sedimentologia do Departamento de Oceanografia da Universidade Federal do Espírito Santo (UFES). 


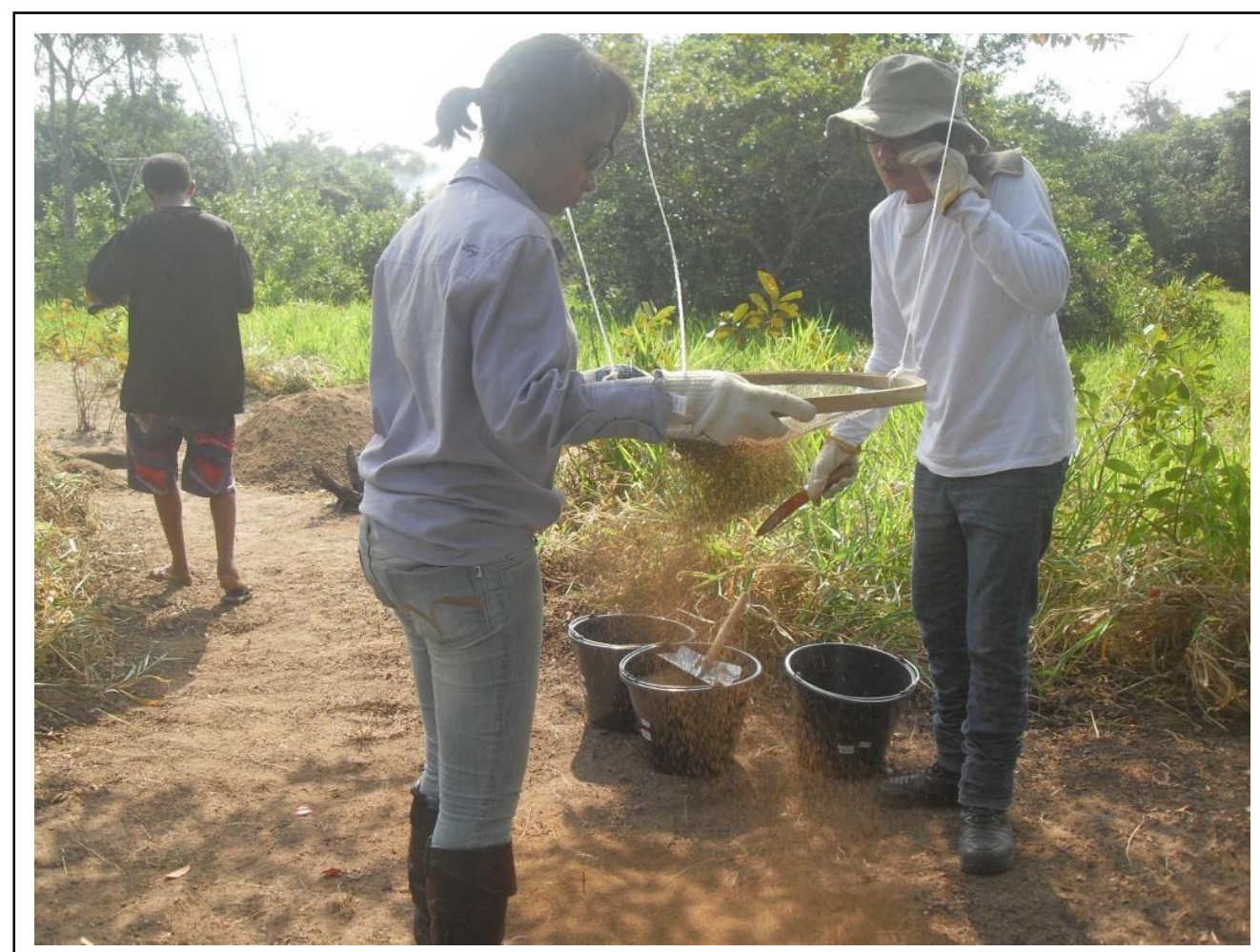

Foto1: Processo de peneiramento. Maria Ester Franklin, set/2012.

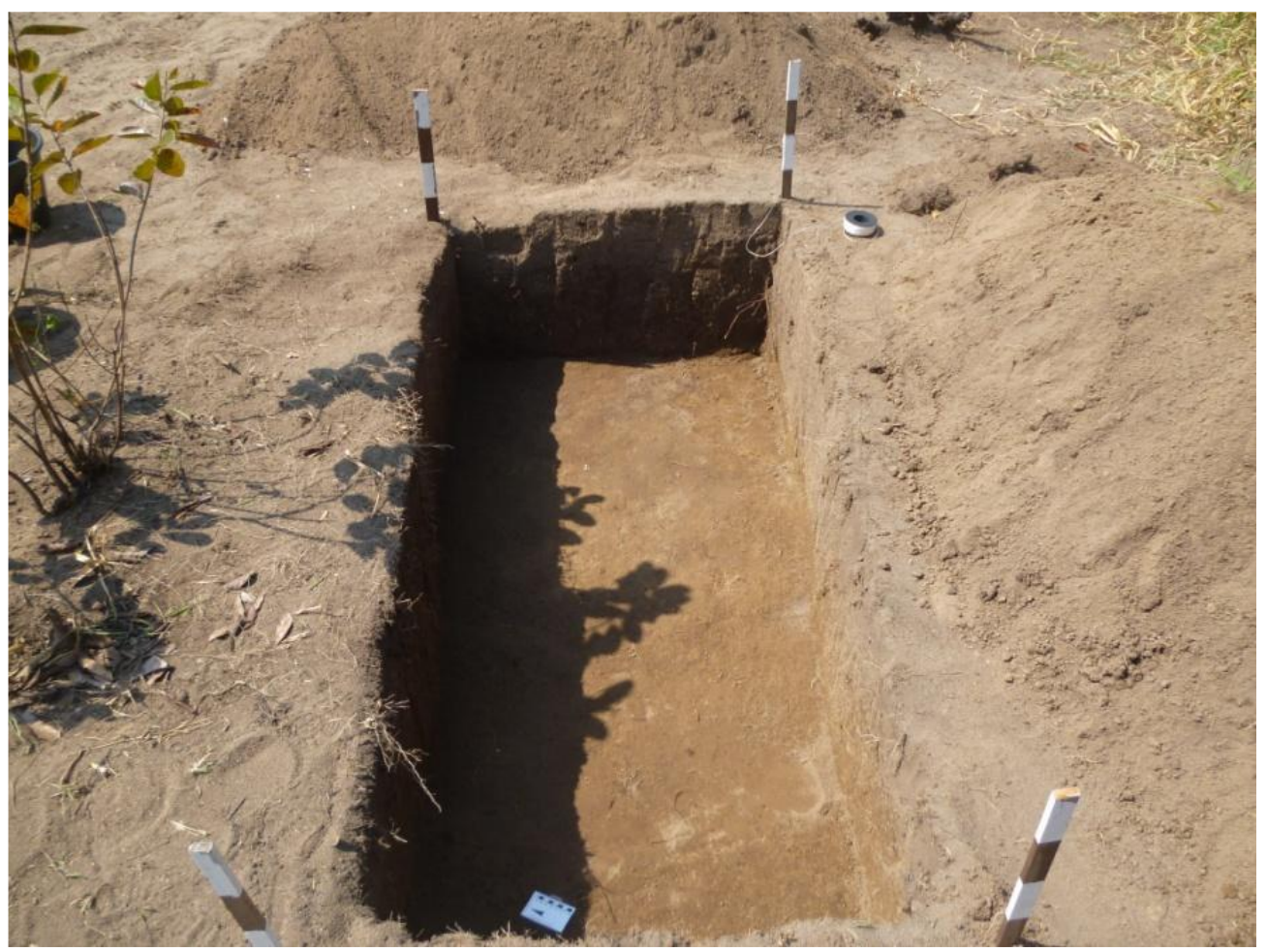

Foto 2: Decapagem do ponto $S_{18}$. Maria Ester Franklin, set/2012.

Fig. 3.2: $1^{\underline{a}}$ campanha de pesquisa de campo acadêmica - set/2012. 


\subsubsection{2 $2^{\mathrm{a}}$ Campanha - dezembro 2012:}

Em dezembro de 2012 uma nova equipe foi reunida para a realização da $2^{\mathrm{a}}$ campanha de trabalho intensivo de campo.

Devido ao fato de o reconhecimento da paisagem e rastreamento preliminar do patrimônio arqueológico, conforme os pressupostos de Morais (2012) já terem sido realizados durante a $1^{\text {a }}$ campanha de pesquisa de campo, a equipe decidiu ater-se diretamente ao Estágio 2 dos procedimentos de campo propostos por esse autor, realizando prospecções com limpeza de área e nova análise das potencialidades arqueológicas e paisagísticas do sítio Limeira.

Durante essa etapa, foi decidido que para o estágio de escavação arqueológicas duas trincheiras seriam escavadas: a primeira, com $10 \mathrm{~m}$, em região perpendicular ao ponto $\mathrm{S} 18$ onde houve intervenção arqueológica na $1^{\text {a }}$ campanha acadêmica e a segunda em posição paralela a S18 e aos Setores 2 e 3 escavados por Perota (2010).

Assim, a equipe efetuou uma limpeza mais refinada de toda a área onde seriam executadas as trincheiras para que fosse possível a determinação dos locais exatos mais propícios para sua realização. Ao encontrar material arqueológico (lítico) em superfície, foram realizados a delimitação e o georeferenciamento dos locais com o auxílio do topógrafo, com utilização de GPS, estacas graduadas (10 em 10cm) e linha de pedreiro.

As duas trincheiras foram executadas, uma paralela à outra entrecortando-se em uma de suas extremidades. A primeira, denominada T1, medindo $10 \times 1$ metros e a segunda, T2, medindo $7 \times 1$ metros (esta, localizada paralelamente ao Setor 2, e a $\mathrm{S}_{18}$ - Figs. 3.1 e 3.3 ).

Durante essa etapa tomou-se o cuidado de observar se havia evidenciação de material arqueológico, instruindo os ajudantes a parar a retirada de sedimento caso aparecessem e sempre se atentando às suas atividades.

Os procedimentos de decapagem por camadas naturais foram realizados nas trincheiras $T_{1},(2 \times 1)$, no intervalo entre 8 e $6 \mathrm{~m}$ ao longo de sua extensão, e $T_{2}(2 \times 1)$ no intervalo entre $4 \mathrm{e} 2 \mathrm{~m}$ ao longo de sua extensão. Todos os vestígios arqueológicos encontrados foram registrados em planilha de campo com seu posicionamento horizontal e vertical e colocados em sacolas plásticas devidamente etiquetadas (com os dados: nome do sítio, data, trincheira, local, e profundidade). 


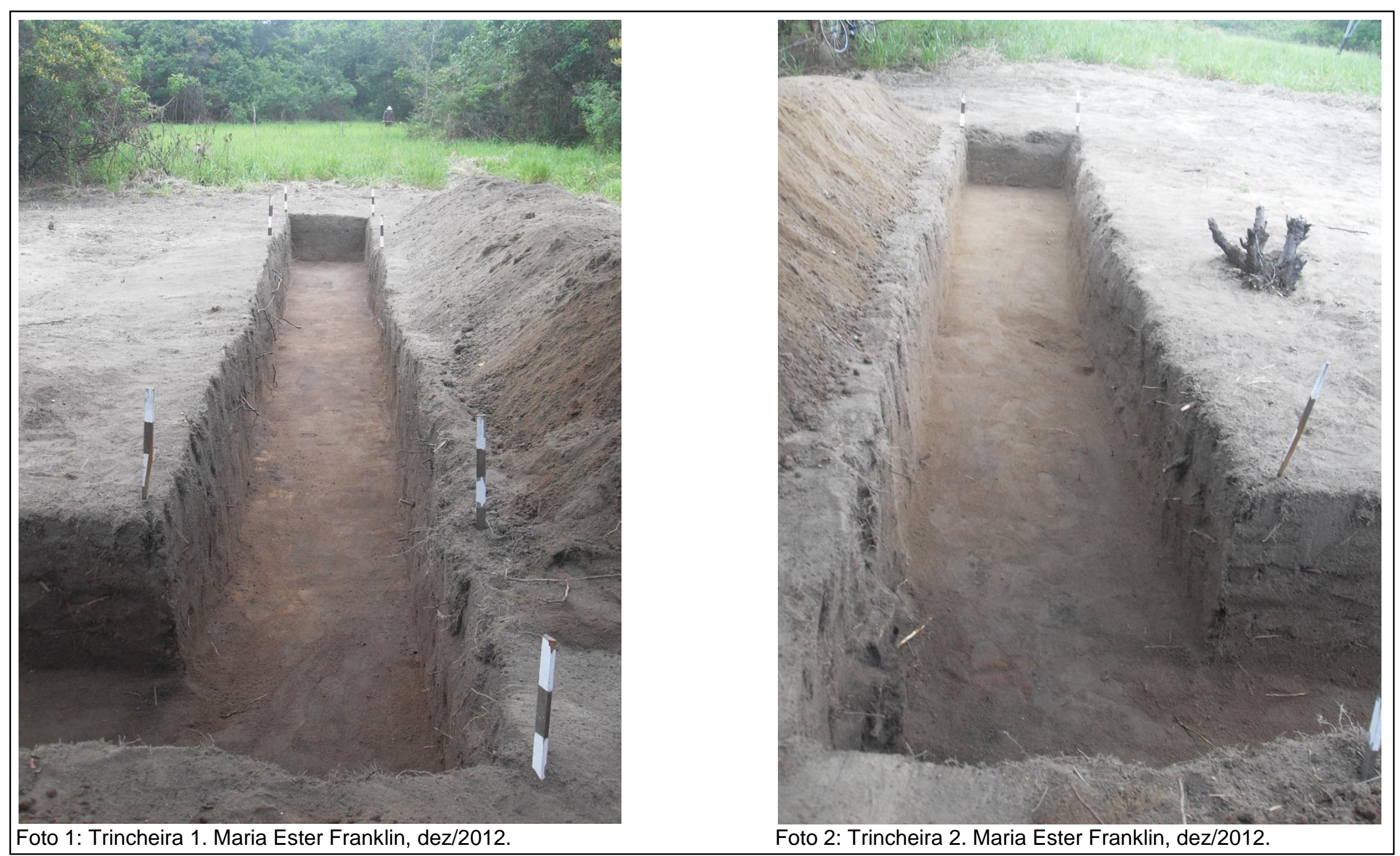

Fig. 3.3:2 ${ }^{\mathrm{a}}$ campanha de pesquisa de campo acadêmica dez/2012. 
Além da trincheira, também foi realizado um perfil estratigráfico, que foi fotografado e desenhado em campo para evidenciação de suas camadas.

Após terminado o perfil, todo o material arqueológico foi devidamente recolhido, acondicionado e etiquetado.

Após o encerramento das atividades de campo, a exemplo da $1^{\text {a }}$ campanha acadêmica, todo o material coletado foi colocado em local protegido, onde os sacos plásticos foram abertos para eliminação da umidade.

\subsubsection{Campanha - maio de 2013:}

Durante a $2^{\mathrm{a}}$ campanha acadêmica de escavação no sítio Limeira, observou-se que na zona de interseção entre as tricheiras $T_{1}$ e $T_{2}$ a coloração de uma parte da camada estratigráfica apresentava-se enegrecida, o que indicava a possibilidade da existência de uma fogueira. Porém, a indisponibilidade de tempo levou a equipe a pensar na possibilidade de realização de uma $3^{a}$ etapa de escavação.

Nessa campanha, decidiu-se por não apenas realizar a decapagem do ponto onde provavelmente havia uma fogueira, como também fazer nova prospecção, dessa vez para encontrar as possíveis fontes de materiais malacológicos coletados pela população que ocupou o sítio Limeira, quanto as prováveis fontes de materiais líticos que poderiam ser encontradas tanto na região do manguezal quanto no leito do rio Jabuti, que deságua em região mais próxima à área que compreende o sítio Limeira e provável fonte de água doce para aquela população.

No mesmo dia, pela manhã, foi realizada uma prospecção ao longo da região da baía de Guarapari adjacente ao sítio Limeira e do leito do rio Jabuti, com equipe devidamente protegida por equipamentos de proteção pessoal e mapa rodoviário e hidrográfico de Guarapari. A prospecção teve início a partir do bairro Camurugi, local onde se encontra o sítio arqueológico Limeira, em direção ao local onde o rio Jabuti não mais sofre influência das águas salgadas da Baía de Guarapari.

Foram percorridos cerca de $3,5 \mathrm{~km}$, sempre acompanhando o curso do rio Jabuti em sentido jusante-nascente, entre matas, chácaras, sítios e fazendas, até que a água doce do rio foi encontrada represada na propriedade da Companhia Espírito Santense de Saneamento (CESAN), na Estação Elevatória de Água Bruta de Jaboti, 
localizada no bairro Jaboti, onde se extrai 600 litros de água por segundo (CESAN, 2013). O fato de o rio Jaboti ter sido represado impossibilitou encontrar naquele momento os seixos que deveriam estar em seu leito.

Uma prospecção ao longo do manguezal foi programada, porém, esta foi adiada até que a maré estivesse a nível favorável a esse tipo de pesquisa.

No dia 21 de maio foi dado início à pesquisa de campo no sítio Limeira, com limpeza da área a ser escavada e adjacências, bem como delimitação e início da decapagem por camadas naturais do ponto denominado $\mathrm{T}_{1 \mathrm{~A}}$, uma continuação de $1 \mathrm{~m}^{2}$ da extremidade sul da trincheira $T_{1}$, local onde a mesma sofre interseção com a trincheira $T_{2}$.

No dia seguinte, foram expostos os primeiros elementos líticos da esperada fogueira, bem como de parte dos carvões que a compõem. Porém, sentiu-se a necessidade de ampliar a área de decapagem de $T_{1 \mathrm{~A}}$, aumentando a área em $1 \mathrm{~m}^{2}$ para sua esquerda e para a sua direita, afim de que toda a fogueira pudesse ser exposta. O processo de ampliação tomou os dias 23 e 24 de maio (quinta e sextafeira). Ao término destas atividade, toda a área de escavação foi (e continuou sendo) coberta com plástico para proteção contra intempéries.

No dia seguinte foi realizado o término do processo de decapagem de $T_{1 A}$ e nova ampliação do ponto em mais $1 \mathrm{~m}^{2}$ para garantia de total exposição da fogueira, desta vez na direção norte à partir de seu ponto central, ou seja, o ponto tomou a forma da letra "T" (Fig. 3.1).

Dia 27 de maio houve o término da decapagem da fogueira, expondo todos os seus elementos superficiais, que apresentaram-se em forma semicircular, e acusando sua profundidade em $32 \mathrm{~cm}$; totalmente compatível com as profundidades nas quais vestígios arqueológicos foram encontrados nas outras campanhas de escavação. Em seguida, foram feitas as medidas verticais ( $83 \mathrm{~cm}$ em sentido $\mathrm{N}-\mathrm{S}$ ) e horizontais ( $68 \mathrm{~cm}$ em sentido L-O), além do quadriculamento da área da fogueira em quadrados de $20 \mathrm{~cm}$ de lado para facilitar a reprodução esquemática em papel quadriculado dos objetos que a compõem (Fig. 3.4).

Após essa etapa, iniciou-se a coleta do material lítico que compunha a fogueira, bem como dos fragmentos de carvão. Pelo fato de os líticos serem de grande dimensão, com em média $20 \mathrm{~cm}$, estes foram depositados em caixas de papelão e identificados quanto a profundidade em que se encontravam. Os carvões foram acondicionados em sacos plásticos também devidamente identificados. 


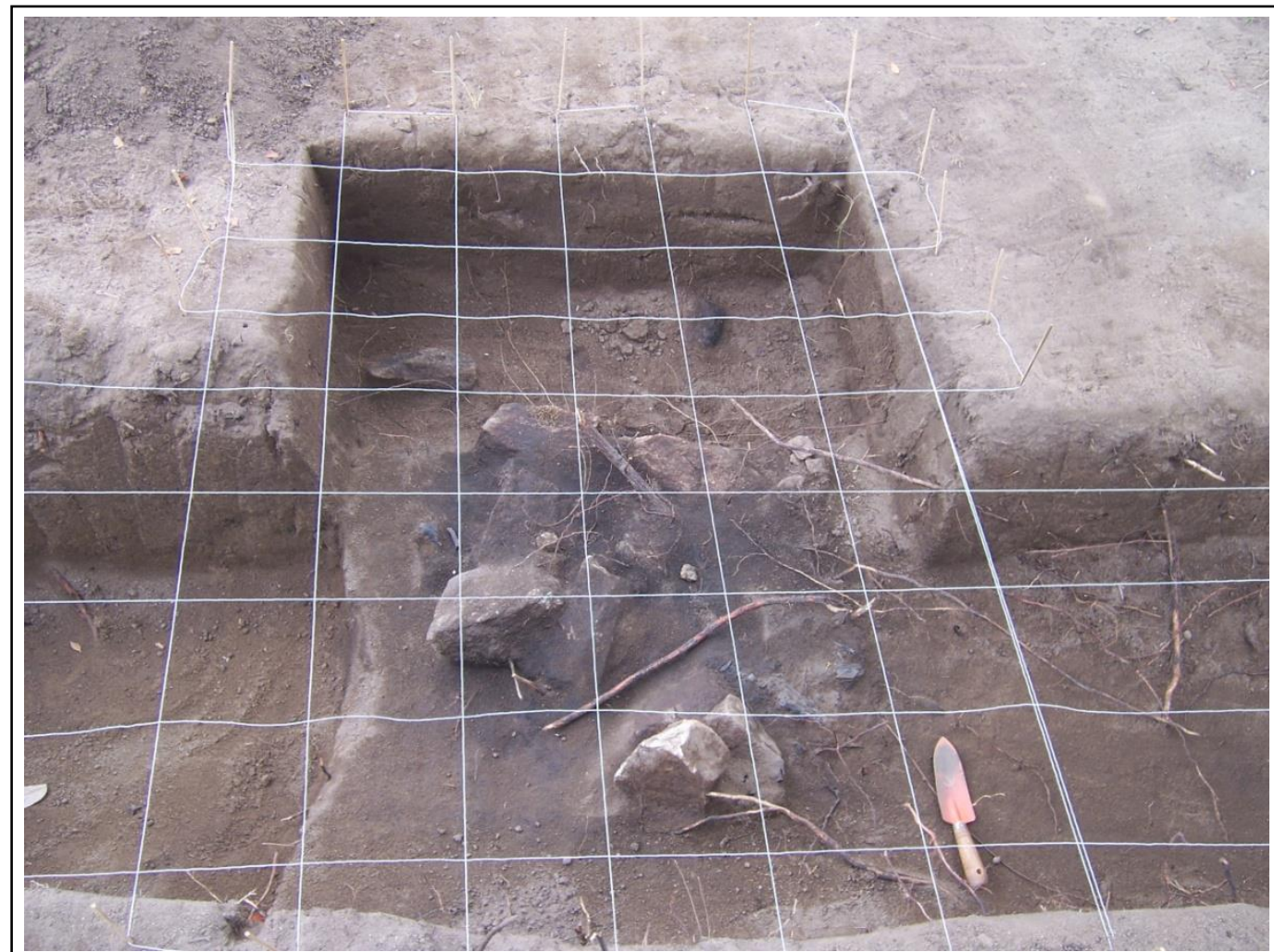

Foto 1: Fogueira $F_{1}$. Maria Ester Franklin - mai/2014.

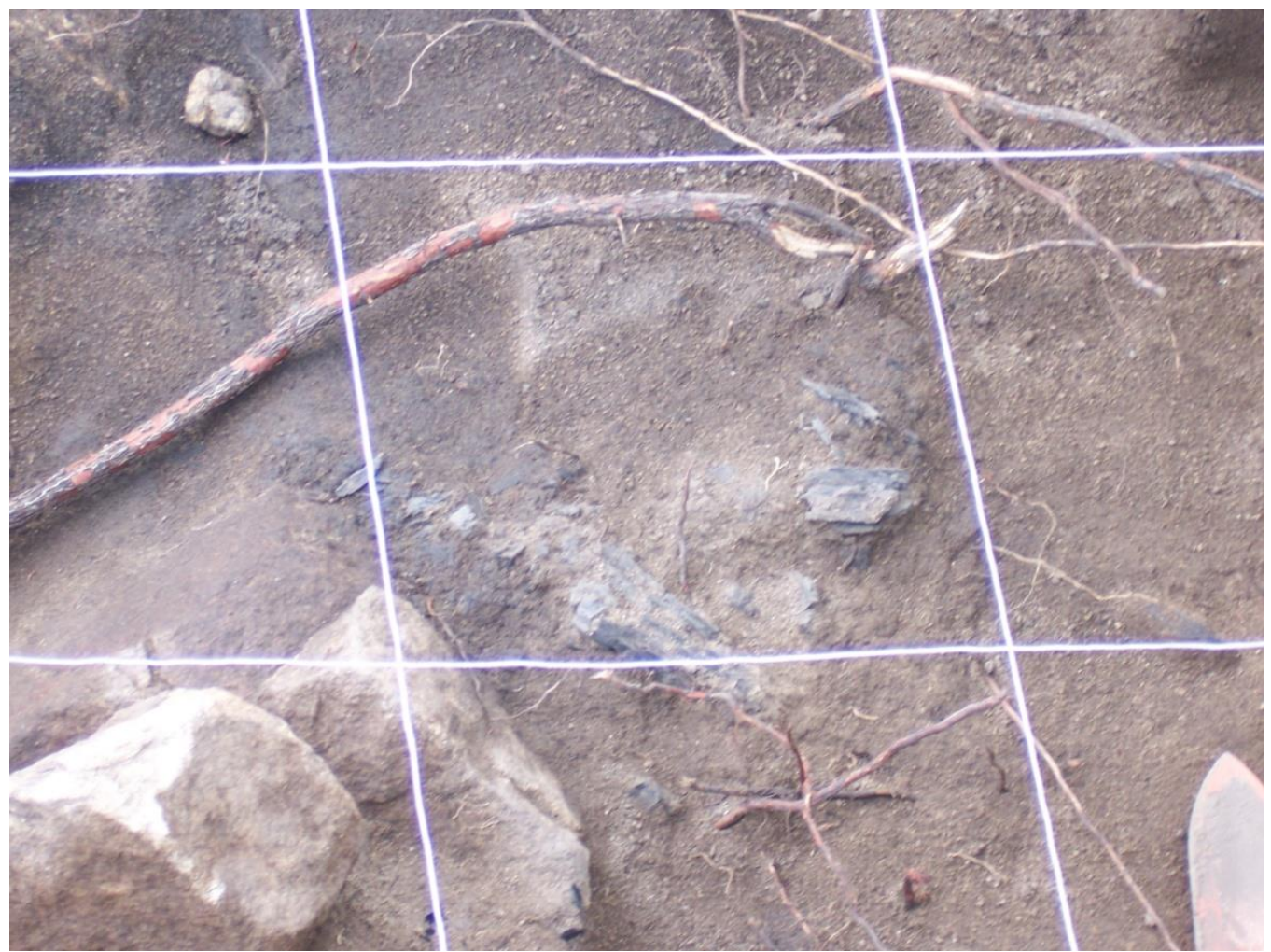

Foto 2: Detalhe da fogueira $F_{1}$. Maria Ester Franklin - mai/2014.

Fig. 3.4: $3^{\text {a }}$ campanha de pesquisa de campo acadêmica - mai/2014. 
Por se tratar de uma fogueira relativamente profunda, com $32 \mathrm{~cm}$ de profundidade, e apresentando alguns de seus elementos líticos empilhados, o trabalho foi realizado minuciosamente, o que tomou todo o dia. Após a realização da decapagem, verificou-se que a fogueira encerrava-se na profundidade de $54 \mathrm{~cm}$.

Afim de que acidentes fossem evitados, toda a área escavada foi apropriadamente soterrada.

Parte do material arqueológico obtido foi levado ao Laboratório de Sedimentologia do Departamento de Oceanografia da Universidade Federal do Espírito Santo; o local de sua guarda. O carvão coletado foi encaminhado para submissão de procedimento de datação por ${ }^{14} \mathrm{C}$.

No dia, 29 de maio, com a maré apropriada, foi realizada a prospecção ao longo do manguezal próximo ao sítio Limeira, com detecção de formações rochosas, e de moluscos gastrópodes e bivalves depositados tanto na superfície sedimentar do espelho d'água do canal do mangue quanto nas extensões dos caules da Rizhophora mangle. e principalmente em costões rochosos dispostos a longo do percurso.

No total foram 9 dias dedicados à $3^{a}$ campanha de escavação.

\subsection{ESTRATIGRAFIA:}

Em relação aos dados levantados in situ, conforme mencionado anteriormente, durante as pesquisas intensivas de campo realizadas no sítio Limeira (tanto de resgate arqueológico quanto de cunho acadêmico) foram realizados perfis estratigráficos.

Com base no relatório de Perota (2010), o perfil estratigráfico ${ }^{30}$ realizado durante a pesquisa de campo para resgate arqueológico apresentou as seguintes características:

\footnotetext{
${ }^{30}$ Não consta no relatório o georreferenciamento desse perfil estratigráfico, porém, sabe-se que fez parte do Setor 2, que pôde ser localizado com precisão, conforme consta no item 3.2 deste mesmo capítulo.
} 
Quadro 3.1: Caracterização do perfil estratigráfico do sítio Limeira Setor 1.

\begin{tabular}{|c|l|}
\hline $\begin{array}{c}\text { Profundidade } \\
(\mathrm{cm})\end{array}$ & \multicolumn{1}{|c|}{ Características do solo: } \\
\hline $0-10 / 15$ & arenoso de cor clara com vegetação rasteira arbustiva e raízes; \\
\hline $10 / 12-40$ & $\begin{array}{l}\text { arenoso de cor escura apresentando restos malacológicos e de } \\
\text { vertebrados, além de evidências arqueológicas, ainda com raízes de } \\
\text { vegetação arbustiva; }\end{array}$ \\
\hline $40-60$ & $\begin{array}{l}\text { arenoso de cor marrom, com poucos restos malacológicos e } \\
\text { nenhuma evidência arqueológica, além de poucas raízes de } \\
\text { vegetação arbustiva. }\end{array}$ \\
\hline
\end{tabular}

Fonte: Perota (2010).

Quadro 3.2: Caracterização do perfil estratigráfico do sítio Limeira Setor 2.

\begin{tabular}{|c|l|}
\hline $\begin{array}{c}\text { Profundidade } \\
(\mathrm{cm})\end{array}$ & \multicolumn{1}{c|}{ Características do solo: } \\
\hline $0-10 / 15$ & $\begin{array}{l}\text { areno-argiloso em uma região da área escavada e arenoso de cor } \\
\text { clara de cor clara com vegetação rasteira arbustiva e muitas raízes; }\end{array}$ \\
\hline $10 / 12-40$ & $\begin{array}{l}\text { arenoso de cor escura apresentando restos malacológicos e de } \\
\text { vertebrados, além de evidências arqueológicas. Uma raiz de vegetal } \\
\text { arbustivo permaneceu no corte até as camadas inferiores. }\end{array}$ \\
\hline $40-60$ & $\begin{array}{l}\text { arenoso de cor marrom, com poucos restos malacológicos e } \\
\text { nenhuma evidência arqueológica, além de poucas raízes de } \\
\text { vegetação arbustiva. }\end{array}$ \\
\hline
\end{tabular}

Fonte: Perota (2010).

Já a estratigrafia realizada durante a etapa de pesquisa intensiva de campo para fins acadêmicos apresentou as seguintes características:

Quadro 3.3: Caracterização do perfil estratigráfico do sítio Limeira - campanha acadêmica.

\begin{tabular}{|l|l|}
\hline $\begin{array}{l}\text { Profundidade } \\
(\mathrm{cm})\end{array}$ & \multicolumn{1}{c|}{ Características do solo: } \\
\hline $1-27$ & $\begin{array}{l}\text { arenoso rico em matéria orgânica com inserção de raízes e vestígios de } \\
\text { queimada natural. }\end{array}$ \\
\hline $28-50$ & arenoso com presença de vestígios arqueológicos (lítico e malacológico). \\
\hline $51-97$ & arenoso, porém com baixo teor de argila e rico em matéria orgânica. \\
\hline $98-123$ & $\begin{array}{l}\text { areno-argiloso de coloração marrom amarelada, apresentando poucas } \\
\text { raízes e sem a presença de vestígios arqueológicos. }\end{array}$ \\
\hline $124-134$ & Embasamento arenítico. \\
\hline
\end{tabular}


Mais tarde o perfil foi digitalizado e redesenhado com a ajuda do software Corel Draw X6. O resultado está exposto na figura 3.5.

Comparativamente, pode-se observar que os resultados obtidos por Perota (2010) são equivalentes aos obtidos durante a pesquisa acadêmica de campo, ou seja, o sítio Limeira está sobre argissolo amarelado, com característica arenosa e baixo teor de argila em suas camadas superiores (horizonte $A$ ), aumentando gradativamente o teor de argila em suas camadas inferiores (horizonte $B$ ).

Além disso, a camada arqueológica é única, ou seja, o sítio Limeira é unicomponencial, e rasa, tendo início já nos primeiros $30 \mathrm{~cm}$ e se extinguindo no máximo aos $50 \mathrm{~cm}$ de profundidade.

\subsection{ESTRUTURAS ARQUEOLÓGICAS:}

Como parte dos processos inclusos na pesquisa intensiva de campo centrados no método Superfícies Amplas de Leroi-Gourhan, foram realizadas decapagens em locais estratégicos para devida análise in situ da camada arqueológica e evidenciação de estruturas e cultura material.

Conforme já mencionado neste capítulo, foram encontrados no sítio Limeira dois tipos de estruturas: malacológicas (na forma de bolsões) e de combustão, ou fogueira, não sendo detectada a área de moradia. A características dessas estruturas são as seguintes:

\subsubsection{Bolsões malacológicos:}

Durante os procedimentos de decapagem foram evidenciados três bolsões malacológicos, dois durante as pesquisass de campo de resgate arqueológico nos locais denominados por Perota (2010) como Setor 1 e Setor 2, e um na realização da pesquisa acadêmica de campo na trincheira $T_{1}$, conforme destaques na Fig. 3.7 Prancha3 $3^{31}$.

\footnotetext{
${ }^{31}$ P.111-114.
} 

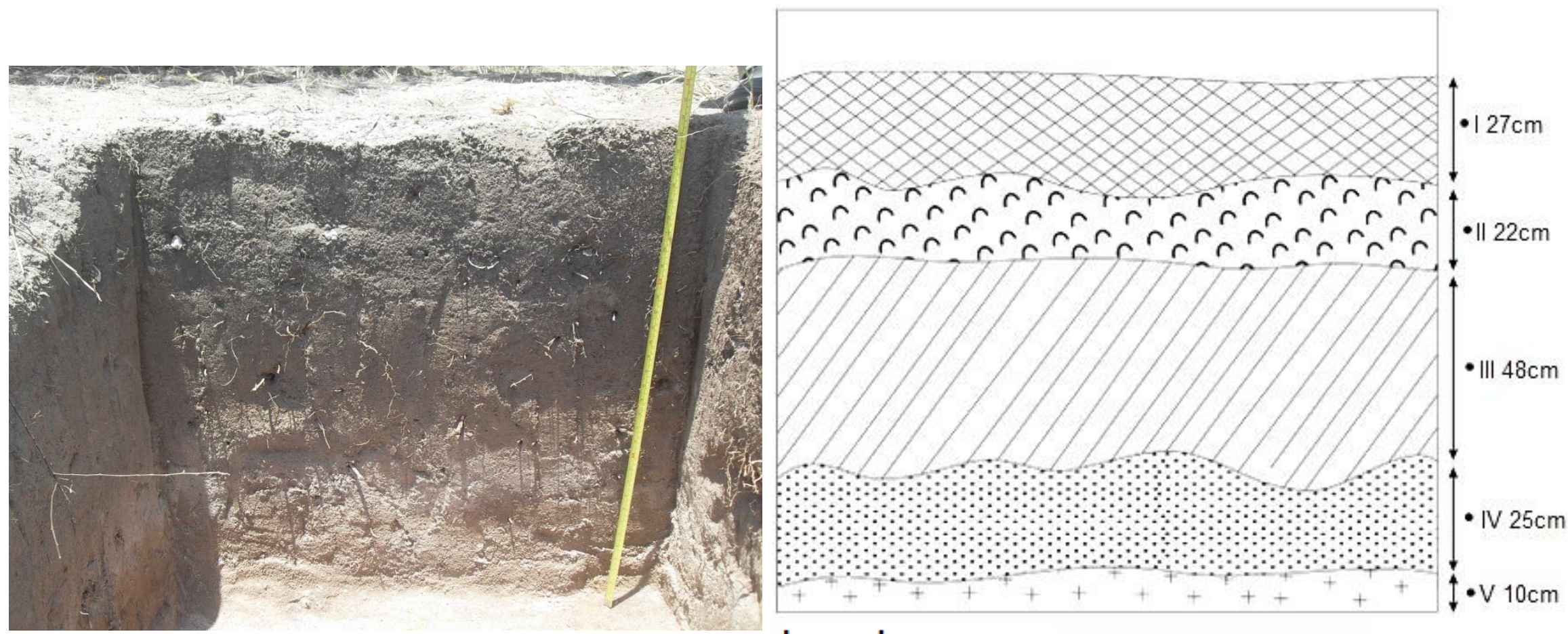

\section{Legenda:}

Org.: Maria Ester Franklin

Des.: Mariana Franklim

mar/2013

Camada arenosa, rica em matéria orgânica, com inserção
de raízes e vestígios de queimada natural
Camada arqueológica (material lítico e malacológico)
Eamada arenosa, rica em matéria orgânica

Fig.3.5 Sítio Limeira - Seção esquemática do perfil estratigráfico. 
Os bolsões malacológicos dos Setores 1 e 2 estão localizados entre 10 e 12cm abaixo da superfície e possuem em média $28 \mathrm{~cm}$ de espessura (Quadros 3.1 e 3.2). Já o bolsão localizado na trincheira $T_{1}$ está a $20 \mathrm{~cm}$ de profundidade e possui $2 \mathrm{~m}$ de extensão e $18 \mathrm{~cm}$ de profundidade (Quadro 3.3).

Os Setores 1 e 2 apresentaram moluscos bivalves e gastrópodes das seguintes espécies:

- Bivalves - Arca imbricata, Crassostrea rhizophorae, Lucina pectinata, e Anomalocardia brasiliana.

- Gastrópodes - Cymatium parthenopeum e Stramonita haemastoma.

Por outro lado, dentre o material malacológico coletado na trincheira $T_{1}$, foram identificados moluscos bivalves e gastrópodes das seguintes espécies:

- Bivalves - Arca imbricata, Crassostrea rhizophorae, Lucina pectinata, Lunarca ovalis, Iphigenia brasiliana e Anomalocardia brasiliana.

- Gastrópodes - Cymatium parthenopeum e Stramonita haemastoma.

Todos os bolsões malacológicos identificados no sítio Limeira não possuem taxas elevadas de concentração de conchas, estando as mesmas misturadas ao sedimento.

Estruturas assim foram encontradas por Uchôa (2007) no sítio do Tenório $\left(22^{\circ} 27^{\prime}\right.$ 8" S e $45^{\circ} 34^{\prime}$ W), localizado no município de Ubatuba, litoral norte do Estado de São Paulo e datado de $1875 \pm 90$ AP. Nesse caso, Uchôa denominou essas concentrações de moluscos de "lentes". As características dos bolsões malacológicos do sítio do Tenório estão expostas abaixo:

- topo relativamente plano ( $2 \mathrm{~m}$ de altitude);

- conchas de moluscos misturadas a sedimento arenoso;

- profundidade de $10 \mathrm{~cm}$ e espessura média de $40 \mathrm{~cm}$;

- superfície praticamente plana;

- conchas associadas a resquícios ósseos de animais terrestres e marinhos (em menor quantidade);

- presença de sepultamentos abaixo de algumas dessas estruturas. 
De acordo com Uchôa (2007), "as concentrações de moluscos geralmente assumiam a forma de lentes, dando a impressão de que detritos de alimentação foram entulhados em covas rasas.", o que converge com as características observadas no sítio Limeira; porém, não foram encontrados sepultamentos nesse local.

Ainda conforme Uchôa (2007), populações que construíam seus assentamentos com tais características (topo plano, material arqueológico esparso com individualização de "bolsões", não possuíram o "traço cultural dos amontoadores de conchas", ou seja, não eram povos do sambaqui. Beltrão e Kneipp (1967) classificam esse tipo de sítio como acampamento, conforme já abordado no Capítulo1.

\subsubsection{Estrutura de combustão - fogueira:}

De acordo com Yar e Dubois (1996), uma fogueira é caracterizada por uma mistura de materiais em cinzas ou carbonados, delimitados ou não por pedras e muitas vezes incluindo restos de esqueletos e artefatos líticos. Para Perlès (1976), os elementos que contribuem para a definição de fogueira são a presença de delimitação de área da estrutura e de uma superfície escavada (cuvette) ou plana "pavimentada" (dallage).

Leroi-Gourhan (1976), ao discorrer sobre o que denominou "estruturas elementares latentes" e "estruturas elementares evidentes" como elementos obrigatórios em uma unidade de habitação humana, colocou as fogueiras nesse segundo grupo, classificando-as como "foyers bordés" (fogueiras rasas) e "foyers em cuvette" (fogueiras escavas).

Yar e Dubois (1996) também destacam a importância de se distinguir claramente o que seriam estruturas de combustão de origem antrópica dos vestígios de combustão natural, o que nem sempre é evidente.

Dessa forma, em acordo com as observações de Parenti (2001), alguns dos indicativos de queimadas naturais são a distribuição generalizada e superficial de cinzas e elementos carbonizados e a alta taxa de oxigenação durante o processo de combustão, já que a vegetação normalmente encontra-se dispersa. 
No sítio Limeira foi observado o padrão acima descrito ao longo do processo de decapagem em vários pontos. Porém, no local sob a UTM 341434E e 7714518S foi encontrado em espaço claramente delimitado, solo arenoso de cor negra acompanhado de rochas dispostas em forma semi-circular ao longo de uma superfície escavada, o que de acordo com Leroi-Gouhan (1976), Perlès (1976) e Yar e Dubois (1996), caracterizam uma fogueira en cuvette, ou na forma de bacia (VILLAGRAN, 2012) - Fig. 3.6.

A fogueira $F_{1}$ observada no sítio Limeira possui $83 \mathrm{~cm}$ de diâmetro na direção $\mathrm{N}-\mathrm{S}$ e $68 \mathrm{~cm}$ de diâmetro na direção L-O, além de apresentar $32 \mathrm{~cm}$ de profundidade. Sua área é delimitada não só pelo solo arenoso carbonizado como por 21 rochas graníticas com tamanhos de, em média, $20 \mathrm{~cm}$ de comprimento, disposta ao longo de toda a superfície escavada, incluindo a região central e mais profunda, ou seja, o fundo da fogueira. Dentro dessa estrutura havia a presença de diversos pedaços de material vegetal na forma de carvão, apresentando de 0,3 a $10 \mathrm{~cm}$ de diâmetro. Tais características podem ser observadas nas figuras 3.4, 3.6 e 3.7 - Prancha 2.

É importante destacar que não foram encontrados vestígios arqueológicos líticos lascados ou polidos dentro da fogueira ou em suas imediações. Também não foram observados restos alimentares na forma de moluscos chamuscados ou carbonizados, ossos de animais, etc. (Fig. 3.4).

Sobre a eficiência desse tipo de fogueira, Villagran (2012) fez uma interessante pesquisa experimental a respeito da eficácia de fogueiras em forma de bacia (conforme sua denominação) e rasa. A primeira foi construída escavando sedimento arenoso, sobre uma paleoduna. Já a segunda sobre um depósito de retrabalhamento de um sambaqui (Cabeçuda, Santa Catarina). O destaque será dado à experimentação da fogueira em forma de bacia, já que possui característica estrutural semelhante à fogueira $F_{1}$ do sítio Limeira.

Conforme Villagran (2012), nesse tipo de fogueira foi possível alcançar temperaturas elevadas, entorno de $900^{\circ} \mathrm{C}$, com preservação de calor de até 12 horas após a finalização da queima. Além disso, de acordo com os resultados apresentados pela autora, todos os componentes faunísticos (conchas e restos de peixe) sofreram calcinação e carbonização. 
Sitio Limeira - Guarapari/ES

Seção esquemática da fogueira $F_{1}$
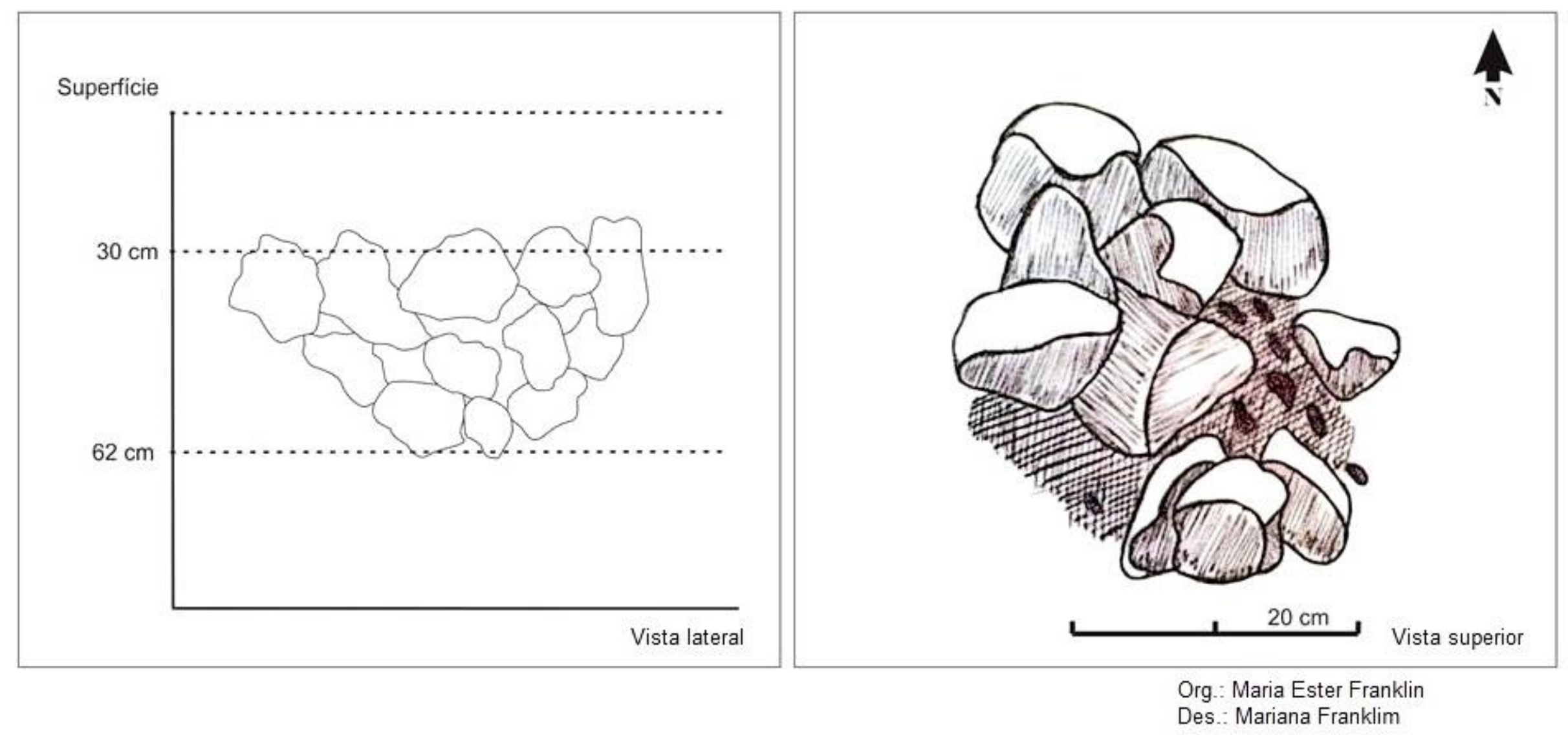

Fig. 3.6: Características da fogueira $F_{1}$. 
Sobre a eficiência desse tipo de fogueira, Villagran (2012) fez uma interessante pesquisa experimental a respeito da eficácia de fogueiras em forma de bacia (conforme sua denominação) e rasa. A primeira foi construída escavando sedimento arenoso, sobre uma paleoduna. Já a segunda sobre um depósito de retrabalhamento de um sambaqui (Cabeçuda, Santa Catarina). O destaque será dado à experimentação da fogueira em forma de bacia, já que possui característica estrutural semelhante à fogueira $F_{1}$ do sítio Limeira.

Conforme Villagran (2012), nesse tipo de fogueira foi possível alcançar temperaturas elevadas, entorno de $900^{\circ} \mathrm{C}$, com preservação de calor de até 12 horas após a finalização da queima. Além disso, de acordo com os resultados apresentados pela autora, todos os componentes faunísticos (conchas e restos de peixe) sofreram calcinação e carbonização.

Quanto à alteração de substrato, segundo Villagran (2012), a escassez de argilominerais e matéria orgânica na constituição do solo da paleoduna fez com que este, apesar das elevadas temperaturas atingidas, não sofresse grandes alterações, como carbonização ou rubefação. Nesse caso, o contrário foi observado em $F_{1}$ que apresentou coloração bastante enegrecida, mas que em contrapartida possui maior quantidade de argila e de matéria orgânica na composição do solo.

A fogueira realizada por Villagrán sobre substrato conchífero também não apresentou escurecimento do substrato apesar de possuir argilominerais e matéria orgânica fina na composição do solo. A pesquisadora atribuiu tal resultado ao fato de que a fogueira sofreu processo de queima durante poucas horas, não podendo provocar esse tipo de alteração física decorrente de elevação térmica.

Nesse caso, a experiência sugere que a fogueira $F_{1}$ do sítio Limeira tenha sido preservada por tempo longo o suficiente para a transferência efetiva de calor ao sedimento a ponto de provocar rubefação do solo, porém, não houve estratificação na estrutura de forma que denotasse longa duração.

\subsection{DATAÇÃO:}

Observando-se a coluna estratigráfica do sítio Limeira (Fig. 3.5) é possível notar que trata-se de um sítio unicomponencial, ou seja, possui apenas um estrato arqueológico. 
Com o afloramento das estruturas arqueológicas (bolsão malacológico e fogueira) através do processo de decapagem por camadas naturais, foi possível obter material arqueológico para datação na forma de conchas (originárias dos bolsões) e carvão vegetal (proveniente da fogueira). Optou-se por enviar parte do carvão vegetal oriundo da fogueira $F_{1}$ para realização de datação por radiocarbono $\left({ }^{14} \mathrm{C}\right)$. Tal análise foi realizada no Laboratório ${ }^{14} \mathrm{C}$ do Centro de Energia Nuclear da Agricultura (CENA - USP).

A amostragem foi realizada primeiramente através da higienização com água em abundância da pá de escavação que seria utilizada e devida identificação de um saco plástico com etiqueta contendo as informações: data, nome do sítio, tipo de material, local da coleta e profundidade. Em seguida, coletou-se uma quantidade considerável de carvão vegetal e depositou-se o mesmo no saco plástico já identificado. Para evitar o esfarelamento da amostra, colocou-se saco dentro de uma vasilha plástica.

Antes do envio da amostra ao laboratório, a mesma foi higienizada mecanicamente, utilizando-se pinça e luvas de látex para retirada dos resquícios de sedimento associados, conforme orientado pelo Prof. Coordenador do Laboratório ${ }^{14} \mathrm{C}$ do CENA-USP, o Prof. Dr. Luiz Carlos Ruiz Pessenda.

Depois disso, a amostra já limpa foi depositada em um recipiente de plástico rígido com tampa devidamente identificado com os dados: nome do sítio e número da amostra. A amostra então foi enviada ao Laboratório ${ }^{14} \mathrm{C}$ do CENA-USP juntamente com um formulário próprio onde estavam contidas informações mais detalhadas como: tipo de material, características físicas do solo, profundidade, características ambientais, etc.

A datação teve como resultado que a fogueira $F_{1}$ teve sua utilização na seguinte época:

- $670 \pm 65 \mathrm{AP}-\left({ }^{14} \mathrm{C}-\mathrm{CENA}-\mathrm{USP}\right)$

Dessa forma, de acordo com o dado exposto, é possível ter conhecimento não somente de que o sítio Limeira foi ocupado antes do Período Colonial, como também obter parte dos dados referentes às características ambientais da região onde está inserido durante o período de sua ocupação através da inter-relação entre 
os dados obtidos em pesquisa intensiva de campo, ambientais e paleoambientais, conforme observado no Capítulo 2. 
Prancha 4 - Líticos

\section{Sítio arqueológico Limeira - Guarapari/ES}

Distribuição espacial das estruturas arqueológicas

$1^{\text {a }}$ campanha acadêmica de escavação - set/2012

$2^{a}$ campanha acadêmica de escavação - dez/2012

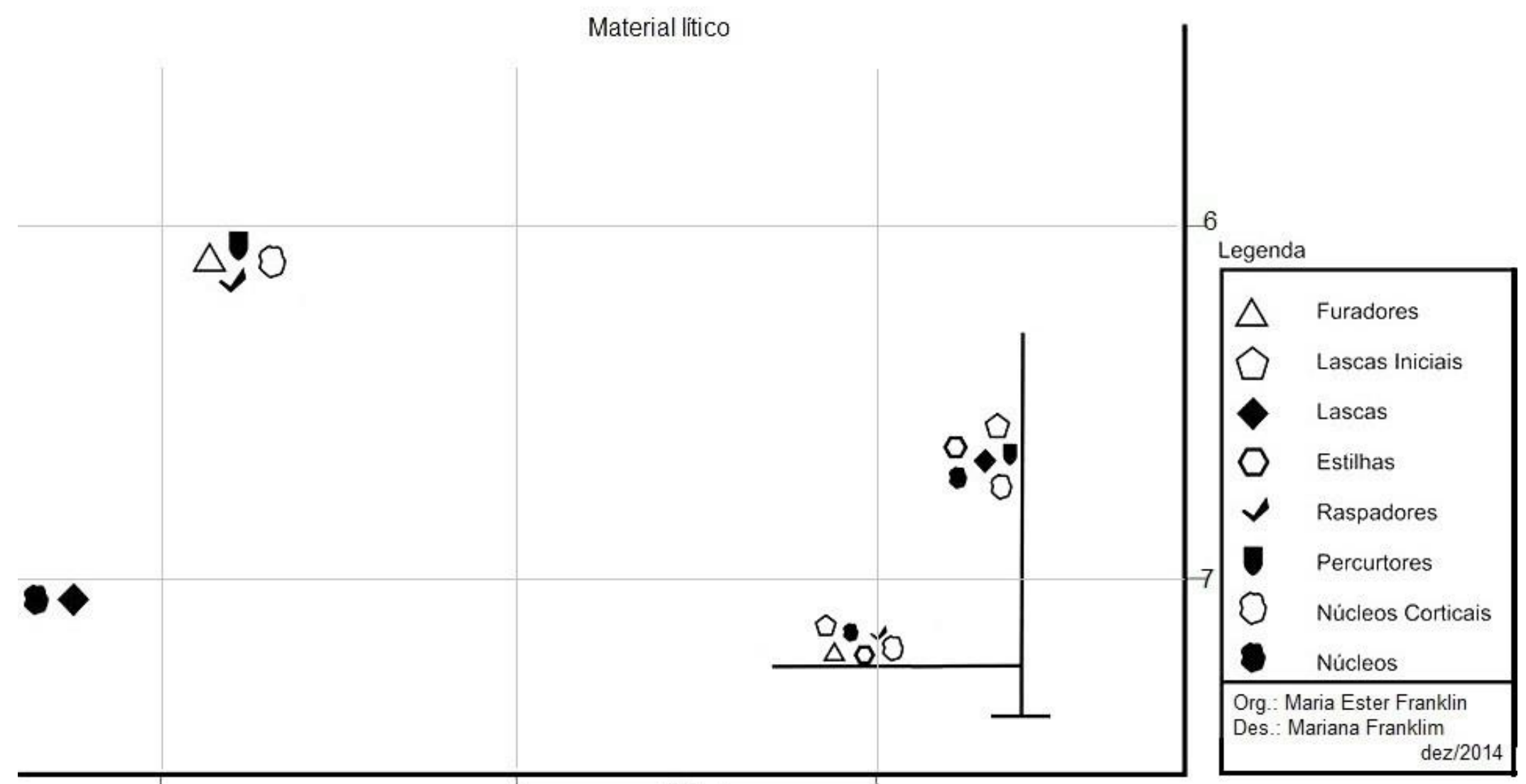

G

H

$10 \mathrm{~m}$

Fig. 3.7: Sítio Limeira - Distribuição espacial do material arqueológico. 
Prancha 3 - Bolsões Malacológicos

Sitio arqueológico Limeira - Guarapari/ES

Distribuição espacial das estruturas arqueológicas

$1^{\text {a }}$ campanha acadêmica de escavação - set/2012

$2^{\mathrm{a}}$ campanha acadêmica de escavação - dez/2012

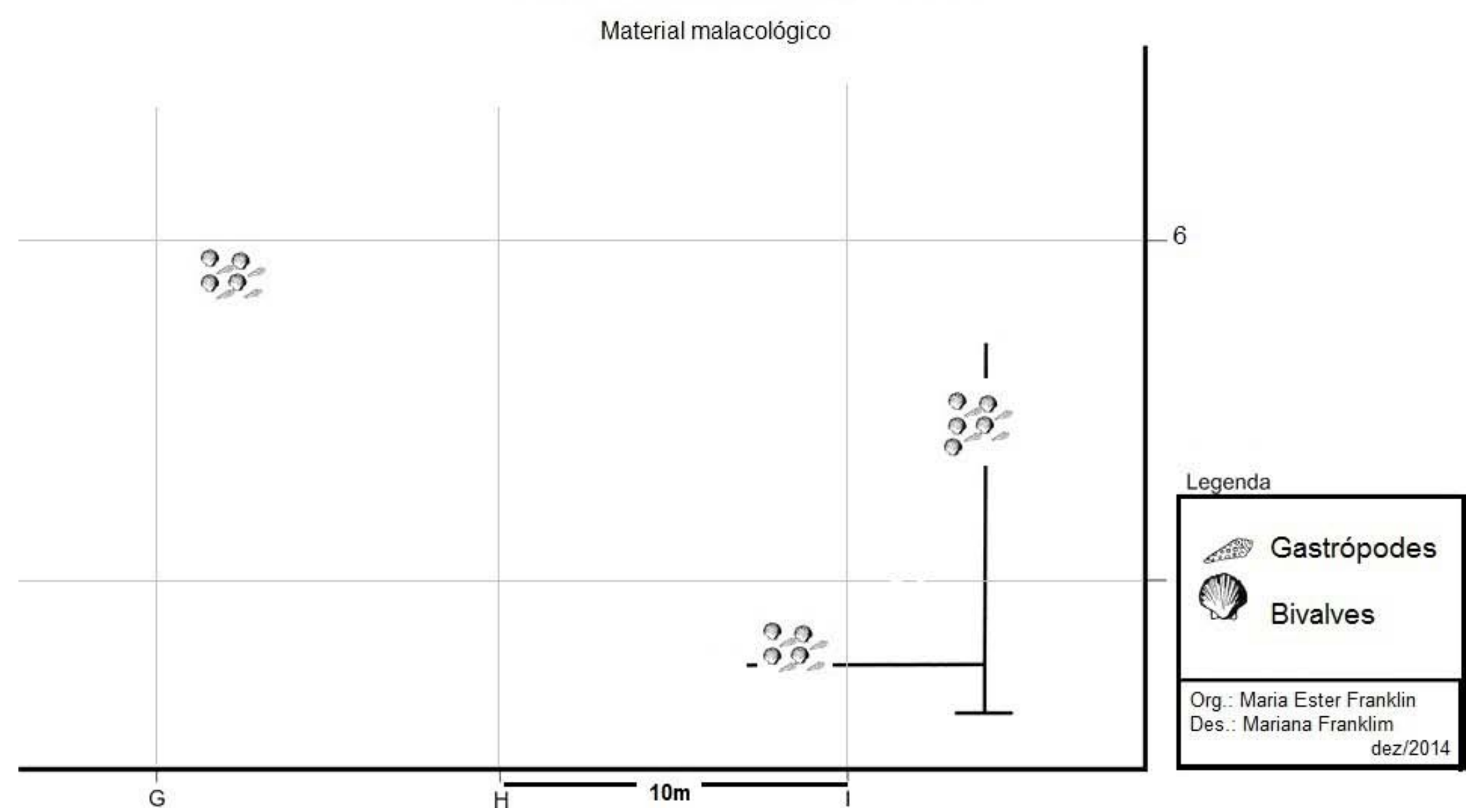

Fig. 3.7: Sítio Limeira - Distribuição espacial do material arqueológico. 
Prancha 2 - Fogueira $F_{1}$

\section{Sitio arqueológico Limeira - Guarapari/ES}

Distribuição espacial das estruturas arqueológicas

$3^{\mathrm{a}}$ campanha acadêmica de escavação - mai/2013

Fogueira

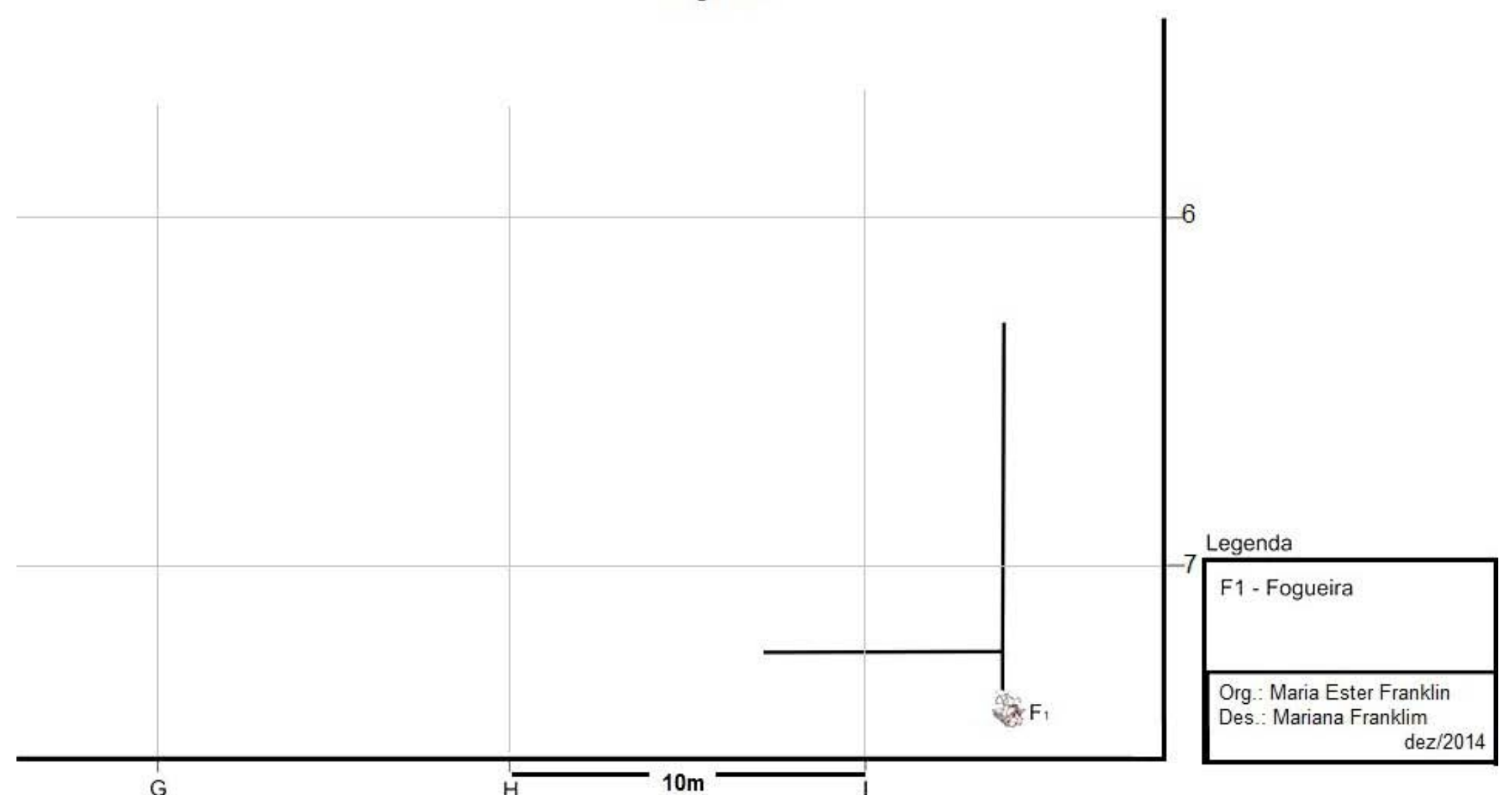

Fig. 3.7: Sítio Limeira - Distribuição espacial do material arqueológico. 
Sítio arqueológico Limeira - Guarapari/ES

Área de escavação do Sítio Limeira

$1^{\text {a }}$ Campanha de escavação - Set/2012

$2^{\text {a }}$ Campanha de escavação - Dez/2012

$3^{\mathrm{a}}$ Campanha de escavação - Mai/2013

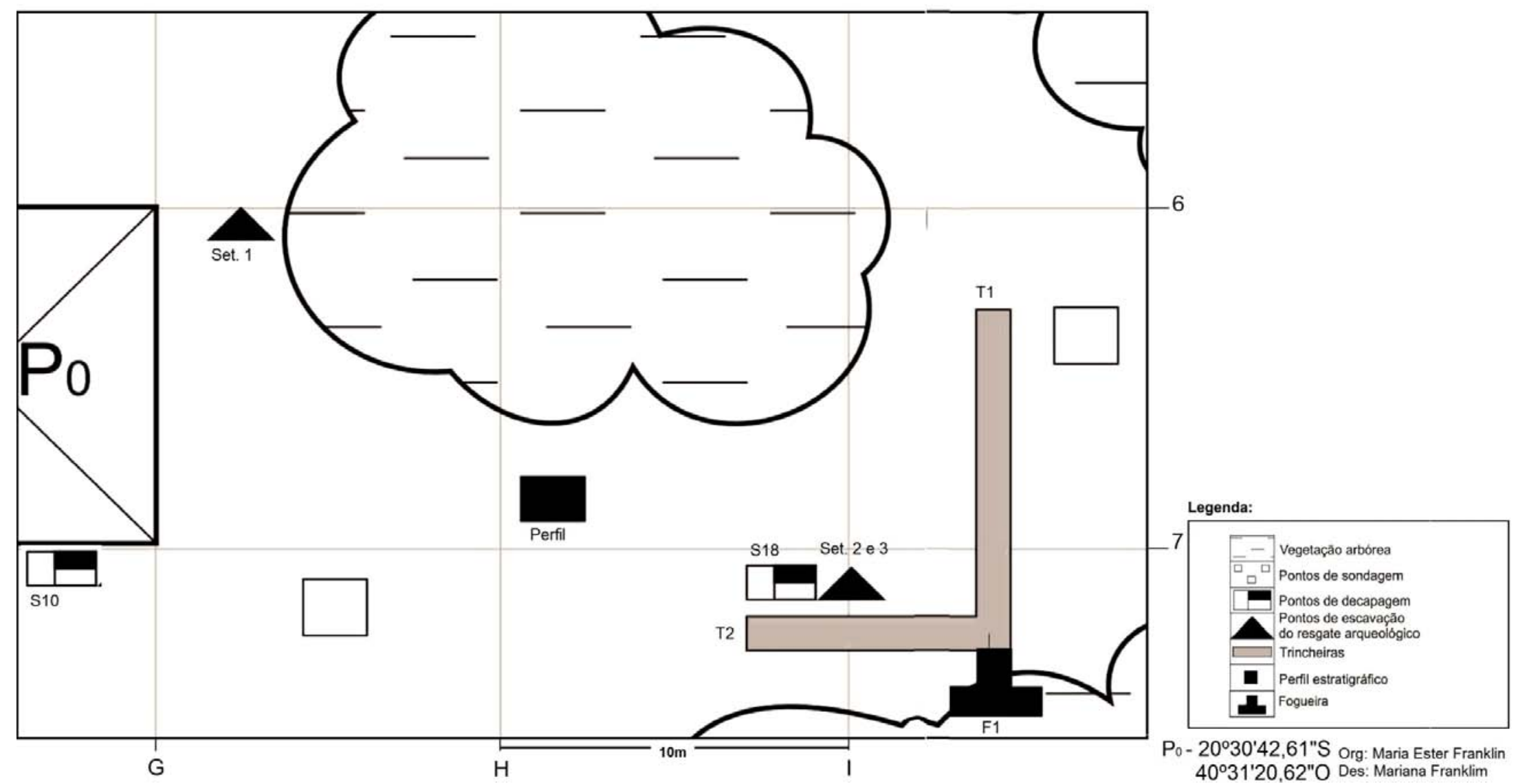

Fig. 3.7: Sítio Limeira - Distribuição espacial do material arqueológico. Prancha 1. 


\section{Capítulo 4}

\section{Análise dos vestígios arqueológicos do sítio Limeira}

Durante a etapa de curadoria desta pesquisa de Mestrado, foram realizadas análises de todo o material coletado no sítio Limeira procedente das 4 campanhas de pesquisa intensiva de campo (incluindo resgate arqueológico e as três pesquisas de campo de cunho acadêmico).

Para isso, processos de higienização, separação das peças líticas por tipo de matéria prima (respeitando sua localização original no espaço do sítio arqueológico), tombo e análises quantitativa e qualitativa foram feitos, totalizando 750 peças líticas.

Além disso, também foi realizada a higienização e análise quantitativa do material malacológico obtido.

Como base teórica para essa etapa foram utilizadas referências bibliografias fundamentais como Brézillon (1968), Tixier (1980) Emperaire (1967), Pallestrini e Chiara (1978) e Morais (1987; 2007).

\subsection{ANÁLISE DOS VESTÍGIOS LÍTICOS:}

\subsubsection{Metodologia de análise da indústria lítica:}

A obra de Brézillon (1983) intitulada "La dénomination des objets de pierre taillée" oferece a padronização dos termos técnicos utilizados no vocabulário de pesquisadores em pré-história de língua francesa não apenas em relação à descrição das características das peças, mas também aludidos aos processos e técnicas que envolvem o trabalho na pedra.

Em "Préhistoire de la pierre taillé", Tixier (1980) aborda desde as características de diferentes tipos de matéria-prima e suas reações ao lascamento, até a exposição 
de experiências, métodos e técnicas de debitagem, além de apresentar um vocabulário de terminologia lítica.

O "Guia para os estudos das indústrias líticas da América do Sul" de LamingEmperaire (1967) é voltado para a identificação e análise da cultura material lítica da América do Sul, organizado em duas partes: a primeira apresenta um glossário, no qual é possível familiarizar-se com os termos técnicos utilizados na descrição e análise de vestígios líticos, e a segunda oferece uma proposta de método de análise desse tipo de material.

Em "Indústria lítica de 'Camargo 76' Município de Piraju - Estado de São Paulo, Palletrini e Chiara (1978) apresentam a aplicação dos critérios de classificação e técnicas de análise da indústria lítica propostos por Brézillon e Laming-Empéraire nas obras já citadas nesta Dissertação.

No artigo "A propósito do estudo das indústrias líticas", Morais (1987) defende a necessidade de padronização não perpetuada na análise das indústrias líticas e propõe a uma ficha tecno-tipológica, com o objetivo de organizar e normalizar itens considerados essenciais para esse tipo de pesquisa.

Dessa forma, Morais (1987) sugere a realização de duas triagens no material de estudo; a primeira separando-o em quatro grandes categorias (massas primordiais, matriz, produtos de talhe, debitagem e retoque e resíduos) e a segunda separando e reagrupando as peças brutas, utilizadas e talhadas e/ ou retocadas.

Além disso, o autor apresenta definições e conceitos em tecnologia e tipologia afim de que possa abranger todos os elementos necessários à compreensão de um objeto lítico que faz parte do conjunto que compõe uma indústria.

Finalmente, em "Tecno-tipologia lítica", Morais (2007), através do texto de sua Tese de Doutorado defendida em 1980, aborda técnicas de análise do tratamento de líticos com base em publicações vinculadas a pesquisas desenvolvidas por Palletrini e Chiara no sítio Camargo entre 1977 e 1978²1, e nas obras já citadas de Brézillon e Laming-Empéraire, dentre outras.

Assim, a análise da indústria lítica do sítio Limeira foi realizada utilizando-se da terminologia, métodos e técnicas expostos por esses autores.

21 PALLESTRINI, L. Camargo 76, Município de Piraju, Estado de São Paulo. Revista do Museu Paulista, N. S., XXIV: 83-110. São Paulo: Museu Paulista da Universidade de São Paulo, 1977.

PALLESTRINI, L. CHIARA, P. Indústria lítica de Camargo 76, Município de Piraju, Estado de São Paulo. Coleção Museu Paulista, Série Ensaios, 2:83-122. São Paulo: Fundo de Pesquisa do Museu Paulista, 1978. 


\subsubsection{Características gerais da indústria:}

O número total de peças obtidas na campanha de resgate arqueológico realizada em 2007 e nas três campanhas de cunho acadêmico realizadas entre 2012 e 2013 estão dispostos no quadro a seguir:

Quadro 4.1: Número de peças líticas coletadas por campanha.

\begin{tabular}{|c|c|}
\hline Campanha/Categoria & № de peças \\
\hline Resgate & 537 \\
\hline $1^{\text {a }}$ camp. acadêmica & 29 \\
\hline $2^{\text {a }}$ camp. acadêmica & 168 \\
\hline $3^{\text {a }}$ camp. acadêmica & 16 \\
\hline Total & 750 \\
\hline
\end{tabular}

Para a realização de um levantamento sobre as características da indústria lítica do sítio Limeira foram realizadas as etapas de higienização, separação por tipo de matéria prima, tombo e análise quantitativa do material lítico.

As análises tecnotipológicas do material lítico foram realizadas no Laboratório de Arqueologia Regional do Museu de Arqueologia e Etnologia da Universidade de São Paulo. A separação por matéria prima foi feita a partir da observação (a olho nu e/ou com auxílio de lupa manual com aumento de 3x), com base em conhecimentos prévios em mineralogia, além de consulta a bibliografia especializada (SUGUIO, 2003; NEVES, 2011; DANA, 1960; KLEIN \& DUTROW, 2012) e a peças do acervo do Museu de Minerais e Rochas do Instituto de Geociências da Universidade de São Paulo.

O tombo foi realizado com auxílio de esmalte incolor, tinta nanquim nas cores preta (para peças claras e transparentes) e branca (para peças escuras), além de caneta com bico de pena. Os dados contidos no tombo são: iniciais do nome do sítio, campanha, local e número de registro da peça com quatro dígitos.

Para realização das análise qualitativas foram utilizadas observações a olho nu, lupa manual com aumento de $3 x$, estereomacroscópio binocular com aumento de até 45x e luz incidente, além de uma luminária acoplada ao balcão do laboratório.

Os resultados das análises quantitativas estão expostos a seguir: 
- Resgate arqueológico - 2009:

De acordo com os dados expostos no relatório realizado por Perota (2010), durante a campanha de pesquisa intensiva de campo foi coletado o seguinte material lítico:

Quadro 4.2: Dados do material lítico coletado no Setor 1.

\begin{tabular}{|c|c|c|c|c|c|}
\hline Class. & & & & & \\
Prof. & $0-10$ & $10-20$ & $20-30$ & $30-40$ & $40-50$ \\
\hline Seixos & & 03 & 02 & 01 & \\
\hline Núcleos & & 02 & 16 & 05 & \\
\hline Percutores & & 05 & 0 & 0 & 2 \\
\hline Lascas & 03 & 46 & 51 & 42 & 12 \\
\hline -Raspadores & 03 & 27 & 70 & 11 & \\
\hline - Furadores & 01 & 03 & 05 & 01 & \\
\hline Pré-pontas & 01 & 0 & 0 & 0 & \\
\hline Total & 08 & 86 & 140 & 60 & 14 \\
\hline
\end{tabular}

Fonte: Perota, 2010.

Quadro 4.3: Dados do material lítico coletado no Setor 2.

\begin{tabular}{|c|c|c|c|c|c|}
\hline \multicolumn{1}{|l|}{ Class. } & $0-10$ & $10-20$ & $20-30$ & $30-40$ & $40-50$ \\
\hline Peixos & 01 & 09 & 02 & 0 & 0 \\
\hline Núcleos & 02 & 06 & 07 & 0 & 0 \\
\hline Percutores & & 01 & 0 & 0 & 0 \\
\hline Lascas & 18 & 66 & 63 & 04 & 0 \\
\hline -Raspadores & 03 & 22 & 21 & 01 & 0 \\
\hline - Furadores & 0 & 02 & 01 & 0 & 0 \\
\hline Pré-pontas & 0 & 0 & 0 & 0 & 0 \\
\hline Total & 50 & 106 & 94 & 05 & 0 \\
\hline
\end{tabular}

Fonte: Perota, 2010.

- $1^{a}$ Campanha de pesquisa acadêmica:

Como se pode observar nos quadros $4.3,4.4$ e 4.5 , durante a $1^{\text {a }}$ campanha acadêmica de pesquisa intensiva de campo foram encontradas poucas peças líticas 
e ainda assim dispersas, havendo pequena concentração de fragmentos de lascas no ponto $S_{10}$, obtidas através de peneiramento, método pelo qual também se localizaram as poucas lascas e fragmentos de lascas encontradas no ponto $S_{18}$.

Quadro 4.4: $1^{\text {a }}$ campanha, coleta de superfície.

\begin{tabular}{|c|c|}
\hline \multicolumn{1}{|c|}{ Prof. } & Superfície \\
\hline Classif. & 05 \\
\hline Núcleos & - \\
\hline Raspadores & - \\
\hline Lascas & - \\
\hline Fragmentos & - \\
\hline Seixos & - \\
\hline Percutores & 01 \\
\hline Furadores & - \\
\hline Corte & 06 \\
\hline Matéria-prima & - \\
\hline Lítico queimado & 12 \\
\hline Total & \\
\hline
\end{tabular}

Quadro 4.5: 1ª campanha, $\mathrm{S}_{10}$.

\begin{tabular}{|c|c|}
\hline Prof. & Peneira \\
\hline Classif. & 02 \\
\hline Rúcleos & - \\
\hline Laspadores & - \\
\hline Fragmentos & 10 \\
\hline Seixos & - \\
\hline Percutores & - \\
\hline Furadores & - \\
\hline Corte & - \\
\hline Matéria-prima & - \\
\hline Lítico queimado & - \\
\hline Total & 12 \\
\hline
\end{tabular}

Quadro 4.6: $1^{1 \stackrel{a}{ }}$ campanha, $S_{18}$.

\begin{tabular}{|c|c|}
\hline Prof. & Peneira \\
\hline Núcleos & - \\
\hline Raspadores & - \\
\hline Lascas & 02 \\
\hline Fragmentos & 03 \\
\hline Seixos & - \\
\hline Percutores & - \\
\hline Furadores & - \\
\hline Corte & - \\
\hline Matéria-prima & - \\
\hline Lítico queimado & - \\
\hline Total & 05 \\
\hline
\end{tabular}


- 2ª Campanha de pesquisa acadêmica:

Nesta campanha foram obtidos resultados muito mais substanciais quanto à cultura material. Durante o procedimento de limpeza da área trabalhada foram encontrados poucos fragmentos líticos dos tipos núcleo e fragmento de lasca. Porém, esses achados foram suficientes para a escolha do local onde seriam realizadas as trincheiras, conforme citado anteriormente. Os dados estão dispostos no quadro abaixo:

Quadro 4.7: 2ª campanha, limpeza de área.

\begin{tabular}{|c|c|}
\hline Classif. & Superfície \\
\hline Núcleos & 04 \\
\hline Raspadores & - \\
\hline Lascas & - \\
\hline Fragmentos & 03 \\
\hline Seixos & - \\
\hline Percutores & - \\
\hline Furadores & - \\
\hline Corte & - \\
\hline Matéria-prima & - \\
\hline Lítico queimado & - \\
\hline Total & 07 \\
\hline
\end{tabular}

Conforme se pode observar, na Trincheira $1\left(T_{1}-10 \mathrm{~m}\right)$, as primeiras evidências de material lítico ocorreram aos $20 \mathrm{~cm}$ de profundidade, na extensão entre $6-7 \mathrm{~m}$, apresentando uma boa variedade de objetos. A concentração de material lítico aumentou com a profundidade, e ao longo da extensão (7-8m), apresentando maior número aos $38 \mathrm{~cm}$, porém a variedade diminuiu e após o ponto de $8 \mathrm{~m}$ não foi encontrado material. Nesse local foram encontrados núcleos, raspadores, lascas, fragmentos de lascas, seixos, percutores e instrumentos de corte, além de amostras de matéria-prima sem forma definida ou marcas de utilização. Importante salientar que, aos $38 \mathrm{~cm}$ de profundidade e 8 metros na extensão de $T_{1}$ foram encontrados 
três fragmentos de arenito com marcas de queima, podendo ter sido utilizados como base de fogueira. Tais dados estão descritos no quadro abaixo:

Quadro 4.8: 2a campanha, $\mathrm{T}_{1}$.

\begin{tabular}{|c|c|c|c|}
\hline Localiz. vert. & $38 \mathrm{~cm}$ & $30 \mathrm{~cm}$ & $20 \mathrm{~cm}$ \\
Classif. Hor. & $7-8 \mathrm{~m}$ & $7-8 \mathrm{~m}$ & 04 \\
\hline Núcleos & 01 & 07 & 04 \\
\hline Raspadores & 06 & 01 & 03 \\
\hline Lascas & 11 & 05 & 03 \\
\hline Fragmentos & 05 & 0 & - \\
\hline Seixos & - & 01 & 01 \\
\hline Percutores & - & 06 & 04 \\
\hline Furadores & - & 01 & - \\
\hline Corte & 02 & - & 01 \\
\hline Matéria-prima & 01 & - & - \\
\hline Lítico queimado & 03 & - & 20 \\
\hline Total & 29 & 21 & 04 \\
\hline
\end{tabular}

Na Trincheira $2\left(\mathrm{~T}_{2}-7 \mathrm{~m}\right)$ foi encontrado menos material, que apareceu à partir dos $30 \mathrm{~cm}$ de profundidade na porção de 6 metros de extensão, em direção à zona de interseção entre as duas trincheiras $T_{1}$ e $T_{2}$. O local apresentou boa variedade de instrumentos em relação à $T_{1}$, com vários raspadores, seguidos de furadores, núcleos, lascas e fragmentos de lascas em menor número. Além disso, foram encontrados seixos, instrumentos de corte e amostra de matéria sem sinal de uso, porém não foram encontrados fragmentos com evidência de queima. Esses dados podem ser observados no quadro abaixo:

Quadro 4.9: 2 ${ }^{\mathrm{a}}$ campanha, $\mathrm{T}_{2}$.

\begin{tabular}{|c|c|}
\hline Prof. & $\begin{array}{c}30-40 \mathrm{~cm} \\
4 \mathrm{~m}\end{array}$ \\
\hline Núcleos & 10 \\
\hline Raspadores & 12 \\
\hline Lascas & 06 \\
\hline Fragmentos & 06 \\
\hline Seixos & 02 \\
\hline \multicolumn{2}{|c}{ Cont. } \\
\hline
\end{tabular}




\begin{tabular}{|c|c|}
\hline Prof. & $\begin{array}{c}30-40 \mathrm{~cm} \\
4 \mathrm{~m}\end{array}$ \\
\hline Percutores & - \\
\hline Furadores & 10 \\
\hline Corte & 02 \\
\hline Matéria-prima & 01 \\
\hline Lítico queimado & - \\
\hline Total & 49 \\
\hline
\end{tabular}

Durante a realização do perfil estratigráfico também foram coletados fragmentos líticos sendo eles: núcleos, raspadores, lascas, fragmentos de lascas, seixos furadores e amostra de matéria-prima sem forma definida ou evidências de uso. Esses dados estão demonstrados no quadro abaixo:

Quadro 4.10: $2^{\mathrm{a}}$ campanha, perfil estratigráfico.

\begin{tabular}{|c|c|}
\hline Plassif. & Perfil \\
\hline Núcleos & 02 \\
\hline Raspadores & 03 \\
\hline Lascas & 06 \\
\hline Fragmentos & 06 \\
\hline Seixos & 02 \\
\hline Percutores & - \\
\hline Furadores & 01 \\
\hline Corte & - \\
\hline Matéria-prima & 01 \\
\hline Lítico queimado & - \\
\hline Total & 16 \\
\hline
\end{tabular}

Os dados relacionados à estratigrafia e aos procedimentos de decapagem do sítio Limeira evidenciaram que trata-se de um sítio unicomponencial, ou seja, com apenas um estrato arqueológico, apresentando vestígios líticos e malacológicos.

Os materiais líticos coletados para análise em laboratório foram divididos nas categorias: contextualizados, quando oriundos de decapagem ou coleta de perfil, e descontextualizados, quando frutos de coleta de superfície ou peneiramento do sedimento. 
Os resultados quanto ao número total de peças obtidas nas 4 campanhas de pesquisa intensiva de campo categorizadas em contextualizadas e descontextualizadas estão dispostos no quadro a seguir:

Quadro 4.11: Número de peças líticas contextualizadas e descontextualizadas.

\begin{tabular}{|l|l|l|l|}
\hline Campanha/Categoria & Contextualizados & Descontextualizados & Total \\
\hline resgate & 537 & 0 & 537 \\
\hline acadêmica & 194 & 19 & 213 \\
\hline Total geral & 713 & 19 & 750 \\
\hline
\end{tabular}

A maior parte do material lítico analisado é oriunda da campanha de resgate arqueológico, quando foram obtidas 537 peças, porém, sem a coleta de material de superfície. Durante as campanhas de cunho acadêmico foram coletadas 213 peças, entre contextualizadas e descontextualizadas. A todas elas foi dedicada a mesma atenção durante o processo de análise, já que todo o material, não importando sua procedência, pode fornecer informações sobre como foi idealizado e confeccionado.

Obedecendo à proposta de Morais (1987), os vestígios líticos do sítio Limeira foram primeiramente organizados em massas primordiais (seixos e blocos), matriz (núcleo), produtos de talhe, debitagem e retoque (lascas), e resíduos. Nesse sentido, teve-se como resultado:

Quadro 4.12: Quantidade de peças líticas por tipo.

\begin{tabular}{|c|c|c|c|c|c|}
\hline Divisão & Seixos e blocos & Núcleos & Lascas & Resíduos & Totais \\
\hline № de peças & 120 & 110 & 453 & 67 & 750 \\
\hline$\%$ & 16 & 14,66 & 60,40 & 8,94 & 100 \\
\hline
\end{tabular}

Como pode ser observado, a maior parte da indústria lítica do sítio limeira é composta por lascas, que representam aproximadamente $60,40 \%$ da amostra, seguida de seixos e blocos (16\%) e núcleos (14,66\%).

Em uma segunda triagem, as peças líticas foram agrupadas em peças brutas, utilizadas e talhadas e/ ou retocadas. Os resultados estão expostos no quadro a seguir:

Quadro 4.13: Quantidade de peças líticas por tipo.

\begin{tabular}{|c|c|c|c|c|}
\hline Peças: & brutas & utilizadas & talhadas e/ou retocadas & Totais \\
\hline quantidade & 696 & 54 & 0 & 750 \\
\hline$\%$ & 92,8 & 7,20 & 0 & 100 \\
\hline
\end{tabular}


Conforme se pode observar, aproximadamente $92,8 \%$ das peças líticas coletadas no sítio Limeira são brutas, ou seja, não apresentam marcas de uso, apenas negativos de retiradas ou cicatrizes decorrentes do processo de debitagem. As peças que apresentam traços de utilização representam 7,20\% da amostra. Nenhuma peça apresentou retoque.

Porém é importante lembrar que a análise do tipo de matéria prima e de suas características é fundamental para a interpretação desses dados, já que muitas vezes o grau de dureza de certos minerais impede a visualização das marcas de uso a olho nu ou até mesmo com utilização de estereomacroscópios, sendo necessária a análise de microtraços através de instrumentos mais específicos para definir se realmente uma peça foi utilizada ou não. Dessa forma, pode-se perceber que a determinação e o estudo da matéria prima que compõe a indústria lítica são de suma importância.

\subsubsection{Matéria prima:}

Como próxima etapa, Morais (1987) sugere a análise das matérias primas que compõem a indústria lítica, pois as técnicas de lascamento estão diretamente ligadas às suas características. Os resultados obtidos do sítio Limeira nos diferentes setores onde o material lítico foi coletado estão dispostos no quadro:

Quadro 4.14: Tipo e distribuição de matéria prima no sítio Limeira.

\begin{tabular}{|c|c|c|c|c|}
\hline & \multicolumn{3}{|c|}{ Matéria prima } & Totais \\
\hline & Granito & Basalto & Quartzo & \\
\hline Setor 1 & 1 & 3 & 304 & 308 \\
\hline Setor 2 & 0 & 4 & 225 & 229 \\
\hline T1 & 2 & 1 & 78 & 81 \\
\hline T2/ & 0 & 0 & 50 & 50 \\
\hline Perfil & 0 & 0 & 17 & 17 \\
\hline Fogueira & 16 & 0 & 0 & 16 \\
\hline S10 & 0 & 0 & 12 & 12 \\
\hline S18 & 0 & 0 & 18 & 18 \\
\hline Col. de Sup. & 0 & 0 & 19 & 19 \\
\hline Totais & 19 & 8 & 723 & 750 \\
\hline \% & 2,53 & 1,07 & 96,4 & 100 \\
\hline
\end{tabular}


De acordo com o quadro, 96,4\% da matéria prima utilizada no sítio Limeira para manufatura do material lítico é constituída por quartzo, seguida de granito, 2,53\% e pouquíssima quantidade de basalto, que representou $1,07 \%$ da amostra.

Uma melhor visualização da distribuição da matéria prima no sítio Limeira pode ser obtida no gráfico:

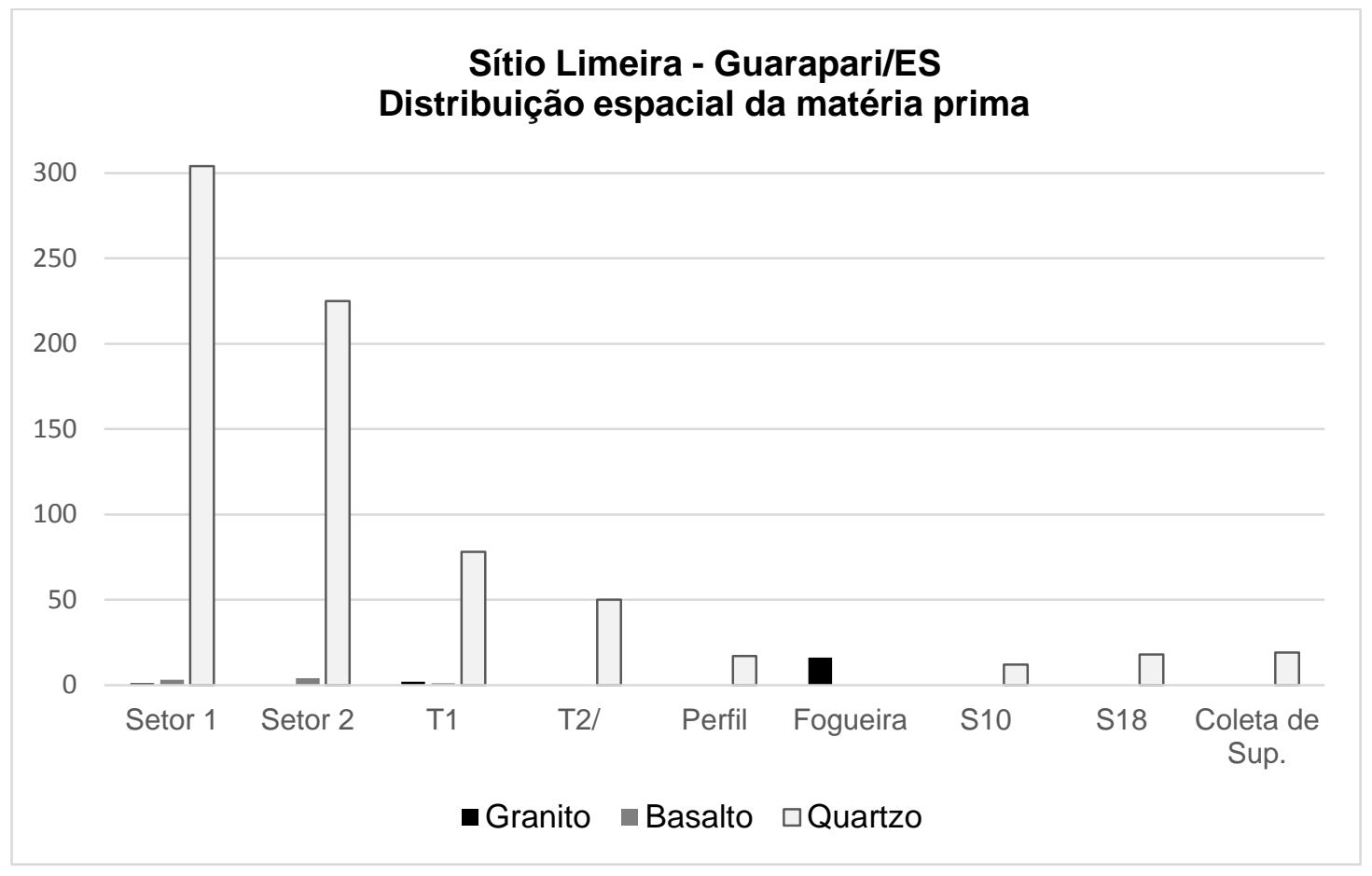

Gráfico 4.1: Distribuição espacial da matéria prima no sítio Limeira.

De acordo com os dados do gráfico 4.1 e do quadro 4.13, é possível observar que nos locais "Setor 1" e "Setor 2" há maior concentração de material lítico, com um total de 308 peças no Setor 1 (304 delas constituídas de quartzo) e de 229 peças no Setor 2 (225 de quartzo). Outro dado interessante é a distribuição de material em granito, que estão concentrados, em sua maioria, na fogueira; de acordo com as características já apresentadas dessa estrutura ${ }^{22}$, essas peças foram utilizadas na sua construção.

De maneira geral, o quadro e o gráfico evidenciam a supremacia da utilização do quartzo em relação às outras matérias primas para a manufatura das peças líticas. Dessa forma, para análise tecnológica, somente as peças em quartzo foram consideradas, já que não poderia ser realizado esse tipo de estudo com quantidades

${ }^{22}$ Essas informações estão contidas no Capítulo 3 desta Dissertação. 
inexpressivas de peças. Para tanto, é evidente a importância de se fazer uma breve revisão a respeito das características desse mineral.

- As características do quartzo

O quartzo $\left(\mathrm{SiO}_{2}\right)$ é o mineral mais abundante do planeta, representando aproximadamente $12 \%$ do total. Sua estrutura cristalina é bem organizada, com cristais prismáticos e estrias horizontais, porém, alguns cristais são mal formados (KLEIN \& DUTROW, 2012); estes geralmente são produto de segregação metamórfica, o que é comum em rochas graníticas na forma de veios, exibindo uma estrutura aparentemente caótica ${ }^{23}$ (DANA, 1960).

Em adição, o quartzo possui brilho vítreo, apresenta-se como transparente a translúcido (quartzo hialino) (podendo apresentar impurezas e assumindo assim, diversas colorações) e fratura concoidal ${ }^{24}$ (DANA, 1960). Esse tipo de fratura faz com que esse mineral apresente características discretas em sua face interna após o lascamento (PROUS, 1986/1190)

O grau de dureza $a^{25} 7$ (D 7) confere bastante resistência a rupturas em sua rede cristalina, como os riscos, (o que inclui marcas de uso deste material em registro arqueológico) e a tenacidade considerada baixa o torna quebradiço e pouco resistente à flexão (KLEIN \& DUTROW, 2012; PROUS, 1986/1990).

Pelo fato de o quartzo ser um mineral com alta dureza e baixa tenacidade, podese concluir que trata-se de uma matéria-prima relativamente difícil de ser trabalhada. Isso foi observado por Bordes (1947):

"Le quartz ordinaire, en galets ou en filons, est un matériel des plus medíocres, (...). Le quartz hyalin,

\footnotetext{
${ }^{23}$ Isso ocorre porque as rochas ígneas são formadas a partir do resfriamento do magma vulcânico. Se esse processo ocorre ao ar livre, o resfriamento do magma é rápido e a rocha formada apresenta brilho vítreo, mas não forma cristais. No caso do quartzo oriundo de veios nessas rochas, devido à baixa temperatura, seu arranjo estrutural passa a ser menos simétrico e mais denso (KLEIN \& DUTROW, 2012).

${ }^{24}$ Fratura concoidal - tipo de fratura que produz superfície com cristas suaves e arredondadas, como a superfície do interior de uma concha (DANA, 1960).

${ }^{25}$ Segundo a escala de dureza de Mohs, que compreende 10 pontos, sendo D1 para o talco, que pode ser riscado facilmente com a unha, e D10 para o diamante, que tem a capacidade de cortar vidro (KLEIN \& DUTROW, 2012).
} 
extrêmement difficile à travailler, a permis parfois d'obtenir de véritables bijoux." 26

(BORDES, 1947. pp. 2)

Morais (2007) através de uma experiência de debitagem com análise comparativa de aptidão de lascamento entre arenito silicificado, sílex e quartzo, concluiu que o quartzo foi a matéria-prima que ofereceu maior dificuldade, não apenas no processo de debitagem, mas também de análise tecnotipológica:

"O quartzo corresponde à matéria-prima de maior dificuldade de tratamento. (...) Mesmo a [sua] análise (...) foge à regra geral, aplicada às outras matérias-primas. É extremamente difícil identificar as características morfológicas de um produto de debitagem em quartzo, cuja fratura não coaduna, quase sempre, com os gestos executados para a obtenção dos produtos de lascamento." (Morais, 2007, p.211)

Prous (1986/1990) também destaca essa característica do quartzo, observando que esse mineral é um exemplo de rocha classificada por ele como frágil, já que ao receber um golpe perto de uma quina, o quartzo solta uma lasca, resultando no surgimento de um gume cortante. Prous conclui que as características de alta dureza e baixa tenacidade favorecem a "criação de instrumentos de corte."

Porém, apesar das dificuldades oferecidas pelo quartzo ao lascamento, é importante destacar que, conforme Morais (2007), esse mineral foi frequentemente utilizado pelas populações pretéritas brasileiras que habitaram a costa meridional do País, sendo uma constante entre as populações sambaquieiras, tendo como fonte dessa matéria-prima os afloramentos em veios presentes nas formações rochosas pré-cambrianas vizinhas ao Oceano Atlântico.

Prous (1986/1990), converge com tal afirmação quando observa que "os instrumentos líticos lascados são feitos geralmente a partir da matéria prima mais comum na região," e adiciona que frequentemente o quartzo está disponível na forma de seixos rolados, que podem ser encontrados nos rios ou nas praias.

\footnotetext{
${ }^{26}$ Tradução livre: "O quartzo comum, em seixos ou veios é um material mais pobre (...). Quartzo
} hialino, extremamente difícil de trabalhar, às vezes permite produzir verdadeiras jóias ". 
As observações acima citadas sugerem que para transformar o material lítico composto por quartzo em um instrumento de uso, é necessário que o artesão saiba como fazê-lo devido às dificuldades oferecidas por essa matéria prima. No entanto, mais do que isso, antes de trabalhar a pedra, ele deve obter a pedra. Dessa forma, para se compreender a indústria lítica e o ser por trás do objeto, é evidente a importância de se analisar os processos de obtenção, transporte e uso da matéria prima.

- Obtenção, transporte e uso da matéria prima

A análise do processo de obtenção, transporte e uso da matéria prima são de suma importância para a compreensão da dinâmica da indústria lítica, já que estão diretamente relacionados à organização tecnológica através da definição de padrões de confecção, manutenção, reciclagem e descarte dos produtos manufaturados (FAGUNDES, 2004).

De acordo com Morais (2007), a indústria lítica está aludida não apenas à natureza, mas também à sua distribuição espacial da matéria prima, pois as populações pretéritas assentavam-se em nichos ecológicos convenientes, sendo a disposição de reservas petrográficas um fator decisivo para a escolha dos espaços habitacionais.

Além disso, fatores como a facilidade nos processos de obtenção, captação e transporte de matéria prima quando realizados nas proximidades do assentamento ou em locais mais longínquos, bem como a preferência ou busca por material para o lascamento com certa qualidade, a própria confecção de instrumentos aptos à utilização dentro de um sistema produtivo, o manejo, a possibilidade de manutenção e reciclagem desses instrumentos entre outros, expressam escolhas sociais (FAGUNDES, 2004).

É importante observar que, conforme Lemonnier (1986), tais escolhas não estão exclusivamente relacionadas ao meio ambiente natural ou às técnicas para lidar com um certo tipo de matéria prima e muito menos possuem apenas um significado, mas podem refletir vários aspectos culturais de um grupo, podendo marcar sua identidade étnica ou ser uma resposta às suas necessidades econômicas. Porém, é importante lembrar que, de acordo com o autor, a análise de uma produção especializada não é suficiente para se obter conclusões nesse aspecto. 
Assim, a escolha por um certo tipo de matéria prima pode estar ligada a diversos fatores, relacionados à disponibilidade, proximidade da fonte, facilidade no tratamento da pedra, tradição tecnológica do grupo, dentre outros (FAGUNDES, 2004; MORAIS, 2007).

De qualquer modo, a proximidade com a fonte de matéria prima é um fator importante a ser considerado, pois é onde se inicia o processo de obtenção de material, podendo ocorrer localmente testes de aptidão para o lascamento ou até mesmo a redução do núcleo, como forma de facilitação do transporte.

A fim de que seja possível obter informações a respeito de potenciais áreas-fonte do material lítico encontrado em um sítio, é necessário identificar o tipo de matéria prima que compõe a indústria lítica, observar suas características através de análises macroscópicas e microscópicas e localizar as reservas petrográficas existentes na área, através do desenvolvimento de prospecções, com base em investigação bibliográficas, cartográficas e de campo para posteriores comparações (JORDÃO, 2010).

Porém, dada a complexidade desses procedimentos e ao tempo reduzido para a pesquisa, foram realizadas apenas as etapas de identificação do tipo de matéria prima das amostras, análises macroscópicas - com observação dos aspectos: dureza, transparência, cor, tenacidade, estrutura, dimensões (núcleos corticais, blocos, seixos e amostras de matéria prima), peso, tipo de córtex e presença ou ausência de talão - e análises cartográficas, bibliográficas e de campo para identificação das reservas petrográficas existentes nas imediações do sítio Limeira.

Dessa forma, os resultados referentes à dureza e tenacidade do quartzo que já foram expostos anteriormente, revelam que esse mineral é considerado duro, com dureza 7, de acordo com a escala de Mohs e de tenacidade frágil ou quebradiça.

Quanto às características referentes aos itens transparência e cor, dentre o conjunto de peças em quartzo, tem-se que mais de $90 \%$ do quartzo é hialino, seguido do quartzo leitoso amarelo. Também foram encontradas peças em quartzo leitoso rosa e branco, porém em quantidade pouco representativa. Esses resultados estão dispostos no gráfico a seguir: 


\section{Tipos de Quartzo (\%)}

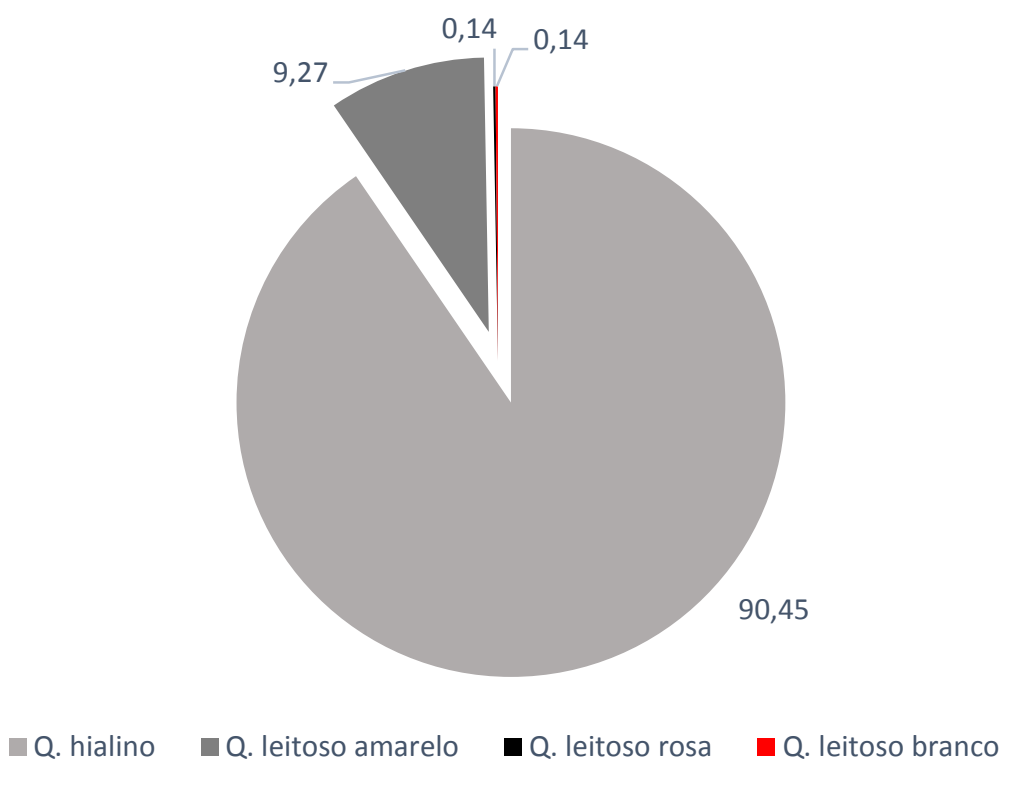

Gráfico 4.2: Diferentes tipos de quartzo encontrados no sítio Limeira.

É importante destacar que todo o quartzo hialino encontrado, cujas características físicas permitem que se identifique qual o tipo de núcleo, é proveniente de seixo e possui estrutura cristalina organizada. Por outro lado, os demais tipos de quartzo possuem cristais mal formados em sua estrutura cristalina, o que sugere que sejam provenientes de veios de quartzo; estruturas comuns em rochas graníticas. O quartzo leitoso amarelo é representado por 67 peças, enquanto há apenas 1 peça dos quartzos leitosos rosa e branco.

Outro fator considerável para se ter informações sobre proveniência de vestígios arqueológicos líticos é a análise do córtex do material. Essa categoria se encaixa na próxima etapa proposta por Morais (1987), a análise de estado de superfície.

Prous (1986/1990) destaca as características do córtex de seixos, dizendo que trata-se de uma alteração na superfície da rocha causada pela ação de intemperismo físico decorrente do processo de "rolamento" dos fragmentos de rocha ao longo dos rios e das praias, sendo esses locais "fontes privilegiadas de matérias primas".

Assim, em relação à indústria lítica do sítio Limeira, 17,33\% das peças possuem mais de $50 \%$ de superfície cortical, enquanto $82,67 \%$ possuem menos de $50 \%$, conforme o quadro a seguir: 
Quadro 4.15: Quantidade de peças em relação à superfície cortical.

\begin{tabular}{|l|lr|r|}
\hline & Córtex & $\%$ \\
\hline$>50 \%$ & & 130 & 17,33 \\
\hline$<50 \%$ & 620 & 82,67 \\
\hline Totais & 750 & 100 \\
\hline
\end{tabular}

Dentre as 130 peças corticais, 9 possuem 100\% de córtex, sendo representadas por:

- 7 seixos/percurtores (com marcas de utilização);

- 1 seixo (sem marcas aparentes de utilização);

- 1 bloco de quartzo rosa (amostra de matéria prima);

A relação completa de peças corticais está representada no quadro abaixo:

Quadro 4.16: Quantidade de peças corticais e sua classificação por tipo.

\begin{tabular}{|c|c|c|c|c|c|}
\hline Tipo de peça & Mat. Prima & $\%$ Córtex & Pres. de talão & Quantidade & Totais (\%) \\
\hline nódulo & quartz amarelo & 70 & não & 1 & 0,77 \\
\hline nódulo & quartzo rosa & 100 & não & 1 & 0,77 \\
\hline bloco & quartz amarelo & $50-70$ & sim (11) não (10) & 21 & 16,15 \\
\hline núcleo & quartzo hialino & $70-90$ & sim & 19 & 14,61 \\
\hline núcleo & quartz amarelo & $70-80$ & sim & 6 & 4,61 \\
\hline seixo & quartzo hialino & 100 & não & 1 & 0,77 \\
\hline seixo/percutor & quartzo hialino & $90-100$ & não & 7 & 5,38 \\
\hline lasca & quartz amarelo & $80-50$ & sim & 25 & 19,24 \\
\hline lasca & quartzo hialino & $50-70$ & sim & 49 & 37,70 \\
\hline Totais & - & - & - & 130 & 100 \\
\hline
\end{tabular}

As peças corticais mais abundantes na indústria do sítio Limeira são as lascas em quartzo hialino (37,70\% do total), seguidas das lascas em quartzo amarelo $(19,24 \%)$, todas apresentando talão. Os blocos em quartzo amarelo representaram $16,15 \%$ da amostra e os núcleos corticais em quartzo hialino (14,61\%). Dentre os blocos citados, a superfície cortical varia entre 50 e 70\%, alguns com talão e outros sem.

Mesmo em análises de proveniência de matéria prima, a presença ou ausência de talão também é relevante. De acordo com Emperaire (1967), o talão, ou plano de percursão, é a superfície (cortical ou não) que recebeu o golpe que destacou a lasca do seu núcleo, sendo que uma parte do talão fina na lasca e a outra fica no núcleo; 
ou seja, a presença de talão, dentre outros fatores, pode ajudar a revelar se o lascamento da peça se deu de forma natural ou por intermédio de ação humana. Nesse caso, a presença de talão sugere a marca de sua extração à partir da rocha original e/ou preparação de núcleo para posterior debitagem.

No caso dos núcleos em quartzo hialino oriundos de seixos, a presença de talão também pode indicar o lascamento proposital; esse dado associado aos fatos de: esses elementos representarem $14,61 \%$ da amostra de peças corticais em quartzo (e $2,91 \%$ do total de peças em quartzo) a presença de seixo sem marca de utilização aparente e superfície 100\% cortical, além de a quantidade expressiva de lascas corticais hialinas e de quartzo amarelo (37,70\% e 19,24\%, respectivamente), sugere que esse tipo de matéria prima foi transportado da área fonte para 0 assentamento para posterior debitagem.

Outros fatores que podem corroborar essa afirmação são as dimensões dos blocos, núcleos corticais, seixos e amostras de matéria prima, e seus respectivos pesos. Tais medidas foram realizadas através do uso de paquímetro e balança de precisão com 3 casas decimais. Os resultados estão demonstrados no quadro abaixo:

Quadro 4.17: Variação das dimensões e pesos das peças líticas separadas por tipo.

\begin{tabular}{|c|cc|c|}
\hline Tipo de peça & Comprim. $\times$ Larg. $\times$ Espess. $(\mathrm{mm})$ & Peso aproxim. $(\mathrm{g})$ \\
\hline amostras mat. pr. & $68 \times 39 \times 33-47 \times 25 \times 24$ & $231,92-74,73$ \\
\hline blocos & $48 \times 34 \times 24-22 \times 21 \times 10$ & $103,80-12,24$ \\
\hline núcleos & $61 \times 45 \times 36-14 \times 13 \times 11$ & $261,87-7,35$ \\
\hline seixos & $57 \times 44 \times 25-13 \times 6 \times 5$ & $166,15-91,65$ \\
\hline
\end{tabular}

Como se pode observar, mesmo as maiores peças não excedem os $6,8 \mathrm{~cm}$ de cumprimento e 231,92g. Dessa forma, pode-se afirmar que essas peças possuem dimensões e pesos reduzidos, o que evidencia a facilidade de seu transporte até o assentamento.

Ainda em relação à matéria prima, observando os tipos de núcleos que compõem a indústria lítica do sítio Limeira pode-se concluir que são provenientes de blocos e seixos. O número de peças de cada tipo e sua representatividade na indústria estão dispostos no quadro a seguir: 
Quadro 4.18: Tipos de núcleo.

\begin{tabular}{|c|c|c|}
\hline Tipo de núcleo & № de peças & $\%$ \\
\hline Seixo & 87 & 79,09 \\
\hline Bloco & 33 & 20,91 \\
\hline Totais & 110 & 100 \\
\hline
\end{tabular}

De acordo com o quadro, os núcleos oriundos de seixos são mais numerosos, compondo $79,09 \%$ da amostra, enquanto os oriundos de blocos são $20,91 \%$.

Reunindo os dados expostos, pode-se constatar que:

- o quartzo foi a matéria prima mais utilizada pelos habitantes do sítio Limeira;

- o sítio Limeira apresenta indústria em sua maioria sobre seixos de quartzo;

- o estado de superfície das peças (como características do córtex e presença de talão), a existência de seixo com superfície $100 \%$ em córtex, além da quantidade expressiva de lascas corticais, associados ao fato de os núcleos e blocos corticais, seixos e amostras de matéria prima possuírem dimensões e pesos reduzidos, sugerem a grande possibilidade de que a matéria prima era coletada junto à áreafonte e transportada para o assentamento para posteriormente sofrer o processo de debitagem;

- Possivelmente a matéria prima não era testada na fonte, sendo levada ao sítio sob a forma de seixos ou blocos em seu estado natural.

Tais constatações constituem possibilidades no caso do sítio Limeira, onde a maior parte de sua indústria lítica é proveniente de seixos, mas que também apresenta vestígios líticos em quartzo característico de veios. Dessa forma, é provável que a origem da matéria prima lítica do sítio Limeira esteja nos blocos retirados dos veios dos afloramentos rochosos graníticos localizados nos costões a menos de $1 \mathrm{~km}$ de distância e, principalmente, nos seixos obtidos às margens do rio Jabuti, o corpo d'água mais próximo do assentamento (Fig. 2.4 e Anexos A, C e D).

\subsubsection{Análise de grupo:}

O próximo passo para a análise de líticos sugerido por Morais (1987), é a análise de grupo, na qual as peças são inseridas em quatro categorias distintas: peças preparatórias, acidentais, utilizadas e artefatos. 
Em relação às peças coletadas no sítio Limeira, tem-se:

- peças preparatórias - seixos, blocos, núcleos e lascas;

- peças acidentais - núcleos e lascas oriundos de ação térmica, lascas

fragmentadas, fragmentos de lascas e lascas siret. Não

foram identificadas;

- peças utilizadas - percutores, furadores e raspadores;

- artefatos - "objetos talhados com a finalidade de se apropriar de uma forma mentalmente concebida". Não foram identificados.

As quantidades e suas respectivas porcentagens em relação ao número total de peças líticas estão expostas no quadro abaixo:

Quadro 4.19: Quantidade de peças preparatórias e utilizadas separadas por categoria.

\begin{tabular}{|c|c|c|c|}
\hline Categoria & Quantidade & Porcent. Relativa (\%) & Porcent. Geral (\%) \\
\hline Preparatórias & & & 4,40 \\
\hline blocos & 33 & 5,10 & 11,60 \\
\hline seixos & 87 & 13,44 & 9,60 \\
\hline núcleos & 72 & 11,13 & 60,40 \\
\hline lascas & 453 & 70,01 & 86,27 \\
\hline Totais & 647 & 100 & 0,93 \\
\hline Utilizadas & & & 3.73 \\
\hline Percutores & 7 & 4.23 & 18,53 \\
\hline Furadores & 28 & 16,10 & 13,5 \\
\hline Raspadores & 139 & 79,67 & 100 \\
\hline Totais & 174 & & \\
\hline
\end{tabular}

Conforme se pode observar, as peças preparatórias representam a maior parte da indústria lítica do sítio Limeira, com $86,27 \%$ do total. Dentre elas, as lascas predominam, com $60,40 \%$, seguidas dos seixos $(11,60 \%)$ e núcleos $(9,6 \%)$.

As peças utilizadas representam $13,5 \%$ da indústria, tendo maior quantidade de raspadores laterais (139) e furadores (28). Esse dado condiz com Morais (2007), onde o autor afirma que as características de clivagem do quartzo proporcionam "uma extremidade aguda extremamente ativa e reforçada, apta à utilização imediata".

As lascas utilizadas como raspadores e furadores não apresentaram muito desgaste pelo uso, o que sugere o não aproveitamento total da peça até o seu 
desuso total. Esse dado pode indicar que não havia dificuldades em encontrar matéria prima para a manufatura das peças, e que provavelmente sua produção era realizada conforme a necessidade, ou seja, que a indústria lítica do sítio Limeira é do tipo expediente, conforme classificação sugerida por Binford (1979) ${ }^{27}$.

Porém, é importante lembrar que o grau de dureza 7 do quartzo faz com que esse mineral não seja riscado com facilidade, o que dificulta a identificação de traços de utilização a olho nu ou mesmo com o auxílio de esteremacroscópio.

\subsubsection{Análise Tecnológica:}

Conforme observado anteriormente, os dados levantados sugerem que o sítio Limeira possui uma indústria lítica expediente, aparentemente simples tecnologicamente e com base de matéria prima principalmente pautada em seixos de quartzo. No entanto, tais características não eximem a necessidade de se realizar sua análise tecnológica.

Lemonnier (1986; 1992) afirma que por mais simples que seja a técnica de uma sociedade pré-histórica, esta possui a caracterização de um sistema que deve ser analisado, pois as técnicas podem ser encaradas como um grupo de escolhas significantes que cada sociedade se vê impelida a adotar dependendo da compatibilidade ou não com outras escolhas.

Para a análise tecnológica da indústria lítica do sítio Limeira, foram consideradas as características físicas dos núcleos e lascas, dos talões, as técnicas de lascamento empregadas e os traços de utilização, quando possível. Os dados coletados foram submetidos a análises estatísticas com o auxílio do software Excell 2010 e interpretados com base nas bibliografias já citadas no item 4.1.1, além de

\footnotetext{
${ }^{27}$ Trata-se de um importante aspecto da organização descrito por Binford (1979), que classifica os objetos líticos em duas categorias: curadoria e expediência. De acordo com o autor, objetos cuja tecnologia era baseada em curadoria eram manufaturados com antecipação ao seu uso e mantidos para serem utilizados um certo número de vezes. Além disso, eram transportados de um local a outro conforme a necessidade de uso e muitas vezes reciclados, mantendo sua função ou adquirindo outra(s). Assim, objetos de curadoria possuem características mais sofisticadas tecnologicamente e com formas mais padronizadas. Por outro lado, ainda de acordo com Binford (1979), objetos de expediência eram manufaturados, utilizados e descartados conforme a necessidade do momento. Dessa forma, esses objetos apresentam-se tecnologicamente mais simples e com formas menos padronizadas devido à resposta imediata exigida para uma atividade específica.
} 
outras obras relevantes, como Bordes (1947), Prous (1986/1990), Prous e Lima (1986/1990), Cadarelli (1983) e Fagundes (2004).

\section{Debitagem:}

A análise do processo de debitagem é de suma importância para a compreensão da tecnologia empregada para a manufatura das peças que compõem a indústria lítica pertencentes a um sítio arqueológico. De acordo com Prous (1986/1990) durante o processo de debitagem o objetivo do artesão pode ter variar, sendo:

- a obtenção de lascas a partir de um núcleo para serem utilizadas como instrumentos (podendo ou não sofrer modificações através de retoques).

- a retirada de lascas como meio de transformar o bloco ou seixo inicial em instrumento.

Prous (1986/1990) destaca que ambos os objetivos podem ser empregados em uma mesma indústria lítica. Assim, tanto os núcleos quanto as lascas, microlascas, estilhas, lamelas, etc., são importantes para a obtenção de informações sobre a tecnologia lítica.

Para a presente pesquisa, cada um dos elementos pertencentes à categoria de grupo estabelecida por Morais (1987) coletados no sítio Limeira foram analisados quanto aos aspectos tipo de debitagem, traços de utilização, dimensões, peso e talão, sempre que possível.

Quanto às técnicas de lascamento, conforme Emperaire (1967), a debitagem pode ocorrer via percussão direta, indireta ou pressão.

\section{Percussão direta:}

- simples - segundo Emperaire (1967), consiste em bater no núcleo com outra pedra (percutor) destacando assim a lasca. A superfície de impacto geralmente é pontual e o peso do percutor determina o tamanho da lasca.

Prous e Lima (1986/1990), denominam essa técnica como lascamento unipolar, e observam que é frequentemente utilizada na fase inicial de debitagem das peças (até mesmo se posteriormente outra técnica de lascamento for utilizada). Os autores 
destacam que no lascamento unipolar, os percutores utilizados "apresentam um desgaste na forma de picoteamento na(s) extremidades ou na periferia da peça, já que a percussão tende a ser aplicada tangencialmente ao núcleo," e que o peso desses instrumentos varia entre 250 e $400 \mathrm{~g}$.

Tais características foram observadas nos percutores do sítio Limeira.

- esmagada - conforme Emperaire (1967), as diferentes técnicas consistem em:

1) pousar o bloco que se quer debitar sobre um suporte e bater com um grande percutor. Essa ação proporciona maior controle do gesto e resulta em dois pontos de impacto, envolvendo o percutor e o suporte; esse é o lascamento bipolar ${ }^{28}$.

De acordo com Prous e Lima (1986/1990), nessa técnica, o artesão segura o percutor em uma das extremidades, mas golpeia o núcleo com a parte próxima do centro da face, nunca utilizando a extremidade do instrumento sob pena de machucar a mão que segura o núcleo a ser debitado. Dessa forma, os indícios de lascamento bipolar são visíveis na bigorna e no percutor. Nesses últimos, as marcas aparecem "numa região situada aproximadamente entre o quarto e o terço distal da face utilizada do instrumento no caso dos percutores mais leves e na parte central no caso dos mais pesados. Ainda conforme Prous e Lima (1986/1990), os percutores utilizados para lascamento bipolar pesam entre 500 e $900 \mathrm{~g}$.

Essas características não foram observadas nos percutores do sítio Limeira.

2) pousar o bloco que se quer debitar sobre superfície de pedra ou osso e dar pequenos golpes no centro da face superior, destacando pequenas lascas que se destacam do bordo em contato com o suporte sobre a face oposta ao contato. A ação resulta em lascamento por contra-golpe.

Não observado no sítio Limeira.

3) instalar sobre o solo uma grande pedra como suporte. Em seguida, segurar o núcleo com as duas mãos acima da cabeça e bater com força sobre o suporte, gerando planos de percussão muito grandes e oblíquos, com bulbo saliente, ponto de impacto visível, cone aparente e algumas vezes múltiplo. Esse é o lascamento sobre suporte.

\footnotetext{
${ }^{28}$ Morais (1987) destaca que a técnica de lascamento bipolar não resulta necessariamente em dois bulbos opostos.
} 
Não observado no sítio Limeira.

Morais (1987), observa que a percussão direta exige que o golpe com o percutor seja forte o suficiente para produzir "uma força que exceda os limites da elasticidade da rocha, proporcionando a fratura." Porém, conforme anteriormente citado, o quartzo possui baixa tenacidade, ou seja, possui uma certa facilidade para sofrer fraturas. Sendo assim, a dificuldade no lascamento do quartzo está no fato de que as fraturas quase sempre "não coadunam com os gestos executados para a obtenção de produtos de lascamento" (MORAIS, 2007), conforme já citado.

Percussão indireta:

Quanto à percussão indireta, segundo Emperaire (1967), essa técnica consiste em colocar um punção (de madeira dura, osso ou chifre e às vezes de pedra) entre o percutor e núcleo. O núcleo é mantido no solo, entre os pés. Uma extremidade do punção é colocada sobre o ponto escolhido e o golpe com percutor é inferido na extremidade oposta.

Morais (1987) destaca que a superfície de impacto resultante (talão) é de pequena extensão, tendendo a ser puntiforme e, eventualmente, apresentando uma pequena cornija em seu ângulo interno.

Não houve indícios de utilização dessa técnica para obtenção de lascas no sítio Limeira.

Lascamento por pressão:

Em relação ao lascamento por pressão, Emperaire (1967) observa que nessa técnica, um retocador (pedra, osso, chifres ou madeira) é aplicado exercendo pequenas pressões sucessivas sobre a parte a ser retocada com a peça na mão. Como resultado, são obtidos resquícios mais finos e regulares, com marcas no núcleo menores que as obtidas por percussão.

De acordo com Morais (1987), as lascas obtidas em lascamento por pressão são geralmente mais uniformes devido ao maior controle dos gestos, porém, essa é uma técnica pouco comum. Além disso, segundo o autor, bastões peitorais, que 
pressionam um núcleo preso ao solo com força obtida através de força empregada pelo peso do tórax também pode ser utilizada para gerar pressão.

Essa técnica não foi observada na indústria lítica do sítio Limeira.

\section{Análise de núcleos:}

Conforme se pôde observar nos quadro 4.16 e 4.17, a maioria dos núcleos coletados no sítio Limeira foram obtidos a partir de seixos. Além disso, suas dimensões variam entre 14 e $61 \mathrm{~mm}$ de comprimento, 13 e $45 \mathrm{~mm}$ de largura e 8 e $36 \mathrm{~mm}$ de espessura. O maior núcleo mede $61 \times 45 \times 36$ e pesa $261,87 \mathrm{~g}$, e o menor, $14 \times 13 \times 11$ e pesa $5,30 \mathrm{~g}$. Os quadro abaixo apresenta as dimensões dos núcleos em relação aos respectivos números de peças que integram intervalos de $5 \mathrm{~mm}$ de comprimento, $5 \mathrm{~mm}$ largura e de $2 \mathrm{~mm}$ de espessura:

Quadro 4.20: Dimensões dos núcleos.

\begin{tabular}{|c|c|c|c|c|c|}
\hline $\begin{array}{c}\text { Comprimento } \\
(\mathrm{mm})\end{array}$ & $\mathrm{n}^{\circ}$ de peças & $\begin{array}{c}\text { Largur } \\
\mathrm{a}(\mathrm{mm})\end{array}$ & № de peças & $\begin{array}{c}\text { Espessura } \\
(\mathrm{mm})\end{array}$ & № de peças \\
\hline $0-5$ & 0 & $0-5$ & 0 & $0-2$ & 0 \\
\hline $6-10$ & 0 & $6-10$ & 16 & $3-4$ & 0 \\
\hline $11-15$ & 15 & $11-15$ & 15 & $5-6$ & 0 \\
\hline $16-20$ & 18 & $16-20$ & 44 & $7-8$ & 9 \\
\hline $21-25$ & 26 & $21-25$ & 21 & $9-10$ & 15 \\
\hline $26-30$ & 9 & $26-30$ & 12 & $11-12$ & 26 \\
\hline $31-35$ & 15 & $31-35$ & 15 & $13-14$ & 15 \\
\hline $36-40$ & 9 & $36-40$ & 0 & $15-16$ & 3 \\
\hline $41-45$ & 6 & $41-45$ & 3 & $17-18$ & 18 \\
\hline $46-50$ & 6 & $46-50$ & 0 & $19-20$ & 9 \\
\hline $51-55$ & 3 & $51-55$ & 11 & $21-22$ & 6 \\
\hline $56-60$ & 0 & $56-60$ & 0 & $23-24$ & 6 \\
\hline $61-65$ & 3 & $61-65$ & 0 & $25-26$ & 0 \\
\hline $66-70$ & 0 & $66-70$ & 0 & $\ldots$ & - \\
\hline $71-75$ & 0 & $71-75$ & 0 & $31-32$ & 3 \\
\hline- & - & - & - & $33-34$ & 0 \\
\hline- & - & - & - & $35-36$ & 3 \\
\hline
\end{tabular}

A sequência de gráficos a seguir $(4.3,4.4$ e 4.5$)$ ilustra de maneira mais clara os dados dispostos no quadro 4.19 , relacionando a frequência de peças (\%) com dados de comprimento $(\mathrm{mm})$, largura $(\mathrm{mm})$ e espessura $(\mathrm{mm})$ : 


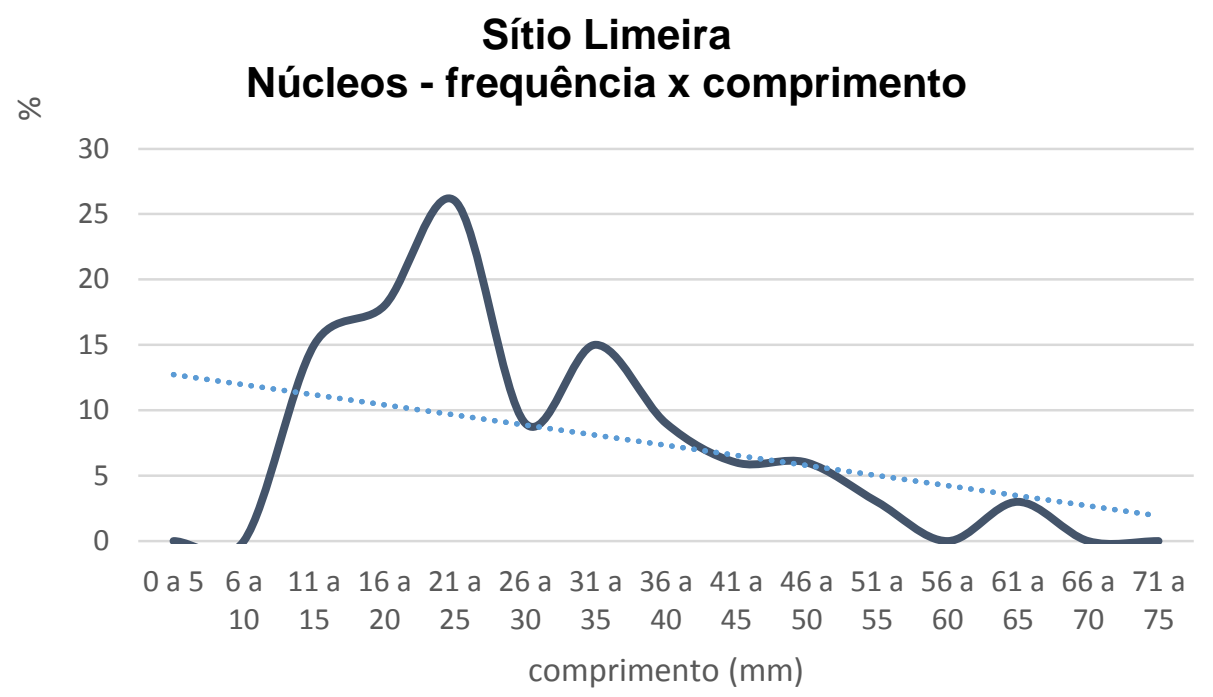

Gráfico 4.3: Relação entre frequência e comprimento dos núcleos.

Observando os dados expostos no quadro e no gráfico 4.3, pode-se concluir que embora o comprimento dos núcleos varie entre 11 e $65 \mathrm{~mm}$, a maioria das peças possui comprimentos entre 16 e $25 \mathrm{~mm}$, representando 53,62\% da amostra, com um leve salto na ocorrência de peças com comprimentos entre 31 a 35mm (13,63\%), mas apresentando tendência a diminuir a sua ocorrência em valores maiores na categoria.

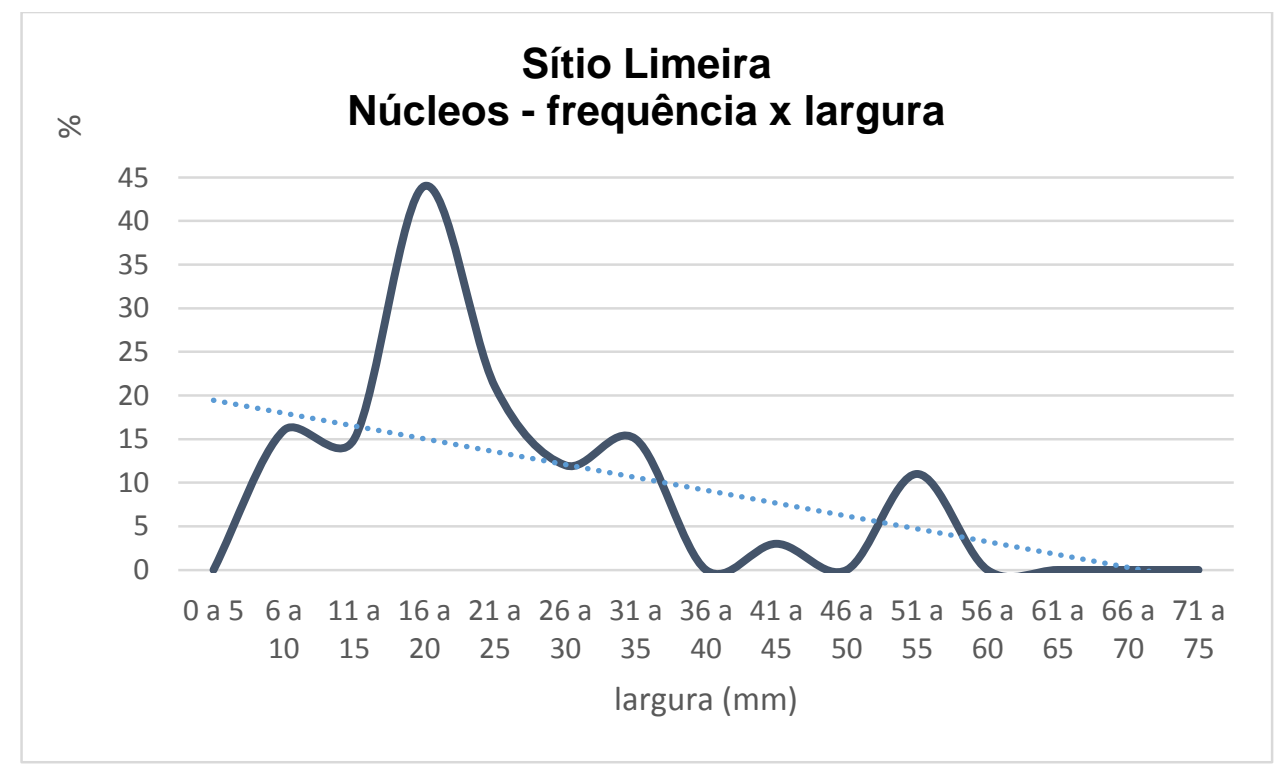

Gráfico 4.4: Relação entre frequência e largura dos núcleos. 
Combinando os dados do quadro 4.19 com o gráfico 4.4, pode-se observar que a largura dos núcleos varia entre 6 e $55 \mathrm{~mm}$, mas a maior parte possui largura entre 16 e $25 \mathrm{~mm}$, o que representa $47,44 \%$ da amostra, com tendência a diminuir a frequência de peças à medida que atinge larguras maiores.

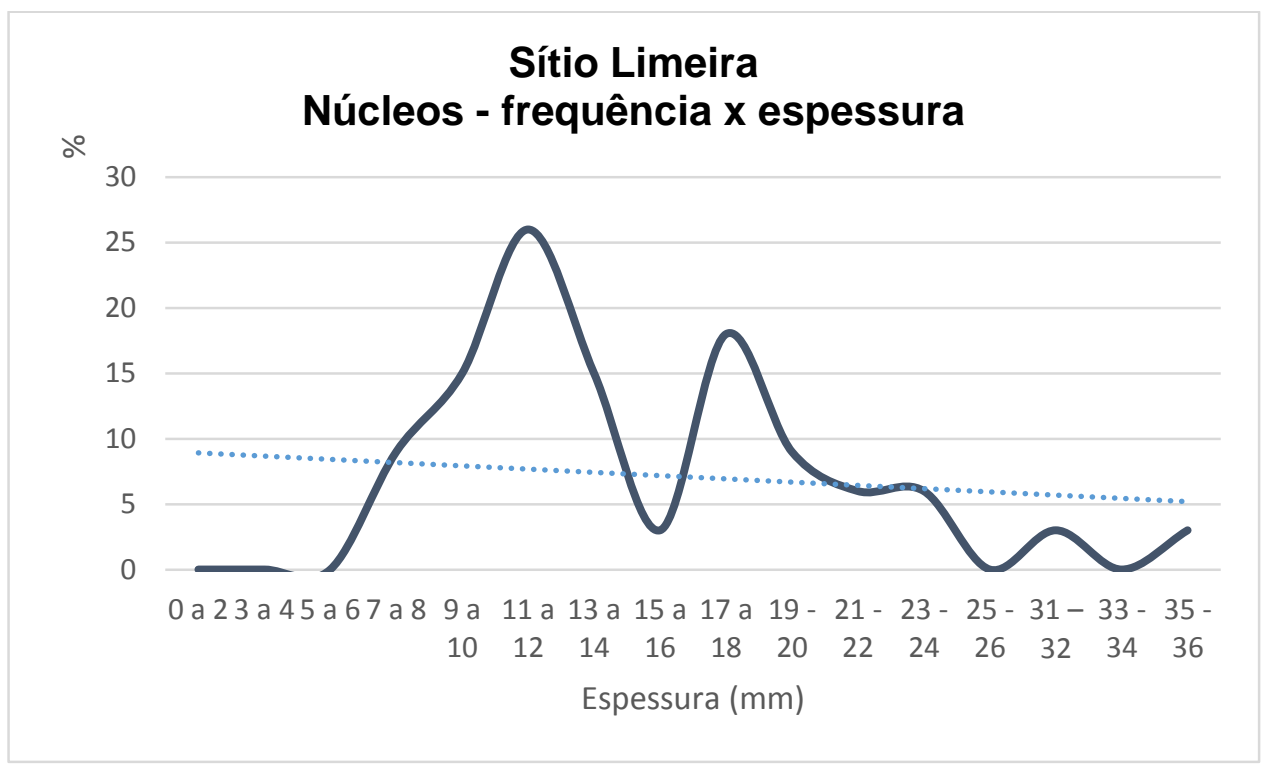

Gráfico 4.5: Relação entre frequência e espessura dos núcleos.

De acordo com os dados expostos no quadro 4.19 e evidenciados no gráfico 4.5, pode-se observar que a amostra possui núcleos com espessuras entre 7 e $36 \mathrm{~mm}$, e a maioria das peças possui entre 9 e 14mm (49,54\%), apresentando um pico entre os núcleos com espessuras de 41 a $45 \mathrm{~mm}$ (16\%), mas sem evidência bem marcada de tendência à diminuição da quantidade de peças à medida que aumenta o valor da espessura. Isso é totalmente justificável, já que núcleos espessos podem produzir mais lascas. O comportamento da amostra apresentado no gráfico 4.5 pode ser justificado pelo fato de os núcleos serem compostos basicamente por seixos.

Em relação ao estado de superfície, Morais (1987) destaca que a observação da superfície cortical é importante, pois revela diferentes estados de descorticamento, ou seja, as etapas de preparação do núcleo ou do talhe dos artefatos.

A alta frequência de núcleos que apresentam córtex (75,46\%) com 22,7\% de núcleos corticais (conforme o quadro 4.15), sugerem que essas peças não apresentam preparo anterior à debitagem, como o descorticamento, e estão ligadas à obtenção de lascas, apresentando planos de percussão em faces favoráveis ao lascamento e em negativos de lascas retiradas. 
Alguns núcleos apresentam múltiplas retiradas em diversas direções. Esses tendem a ter formas globulares e são de quartzo hialino. Segundo Caldarelli (1983) núcleos com essas características não produzem lascas com formas padronizadas, o que pôde ser observado no sítio Limeira.

Outros núcleos do sítio Limeira também não apresentam preparação especial e possuem um único plano de percussão, provavelmente porque a debitagem não produziu planos de percussão favoráveis, acarretando em um estado menos avançado de debitagem, ou seja, tais peças possuem maior superfície cortical.

O estado de superfície do núcleo também pode ser relacionado à sua forma. Os núcleos coletados no sítio Limeira apresentam-se sob as formas: globular, triangular, trapezoidal e indefinida. Os núcleos trapezoidais são os que apresentaram maior superfície cortical, e os globulares possuem superfície com menor quantidade de córtex. Esses resultados estão expostos no quadro 4.20 e nos gráficos 4.6 e 4.7 a seguir:

Quadro 4.21: Aspectos formais dos núcleos do sítio Limeira.

\begin{tabular}{|l|l|l|}
\hline Formas & № de peças & Porcentagem (\%) \\
\hline Globular & 20 & 17,17 \\
\hline Trapezoidal & 15 & 12,63 \\
\hline Triangular & 72 & 64,44 \\
\hline indefinida & 13 & 11,81 \\
\hline Total & 110 & 100 \\
\hline
\end{tabular}

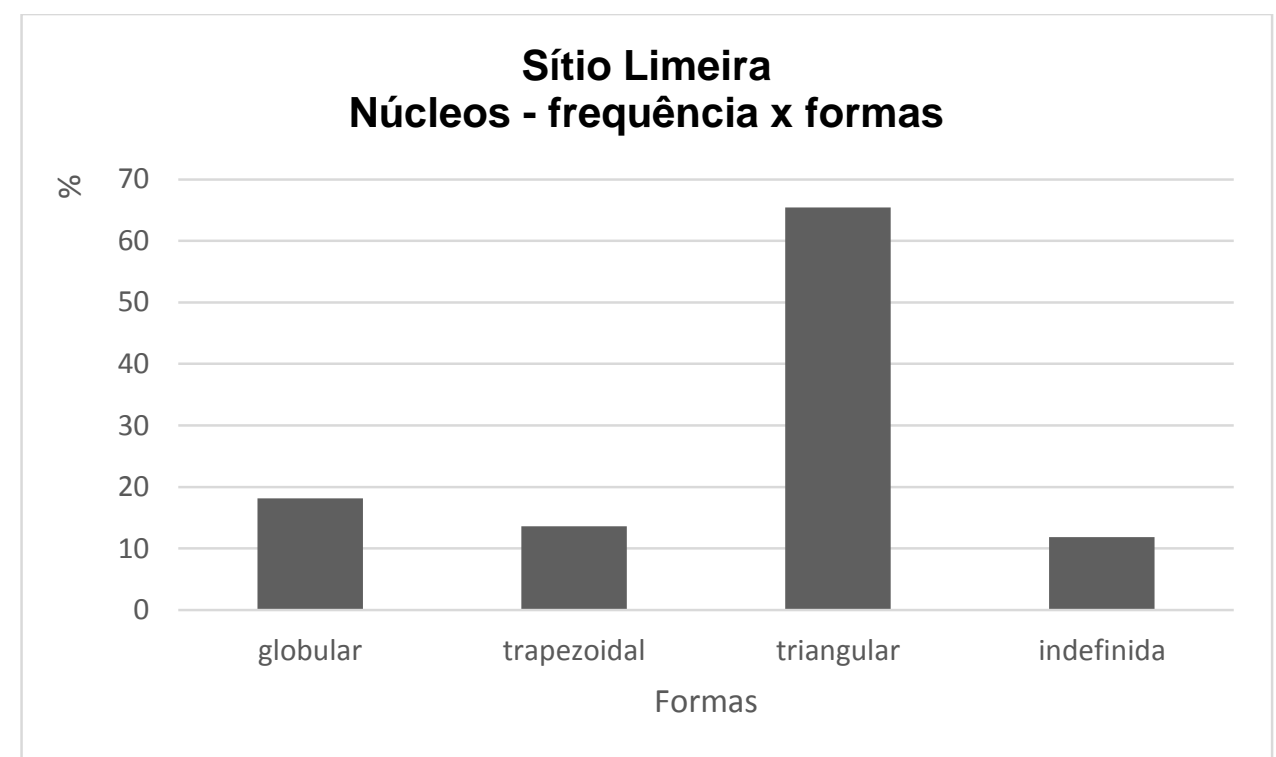

Gráfico 4.6: Relação entre frequência e formas do núcleos. 
De acordo com os dados observados no quadro 4.20 em face ao gráfico 4.6, a maior ocorrência de núcleos no sítio Limeira está sob a forma triangular, que representa $65,45 \%$ da amostra, seguida pela forma globular (18,18\%). As peças menos representativas possuem forma indefinida $(11,81 \%)$.

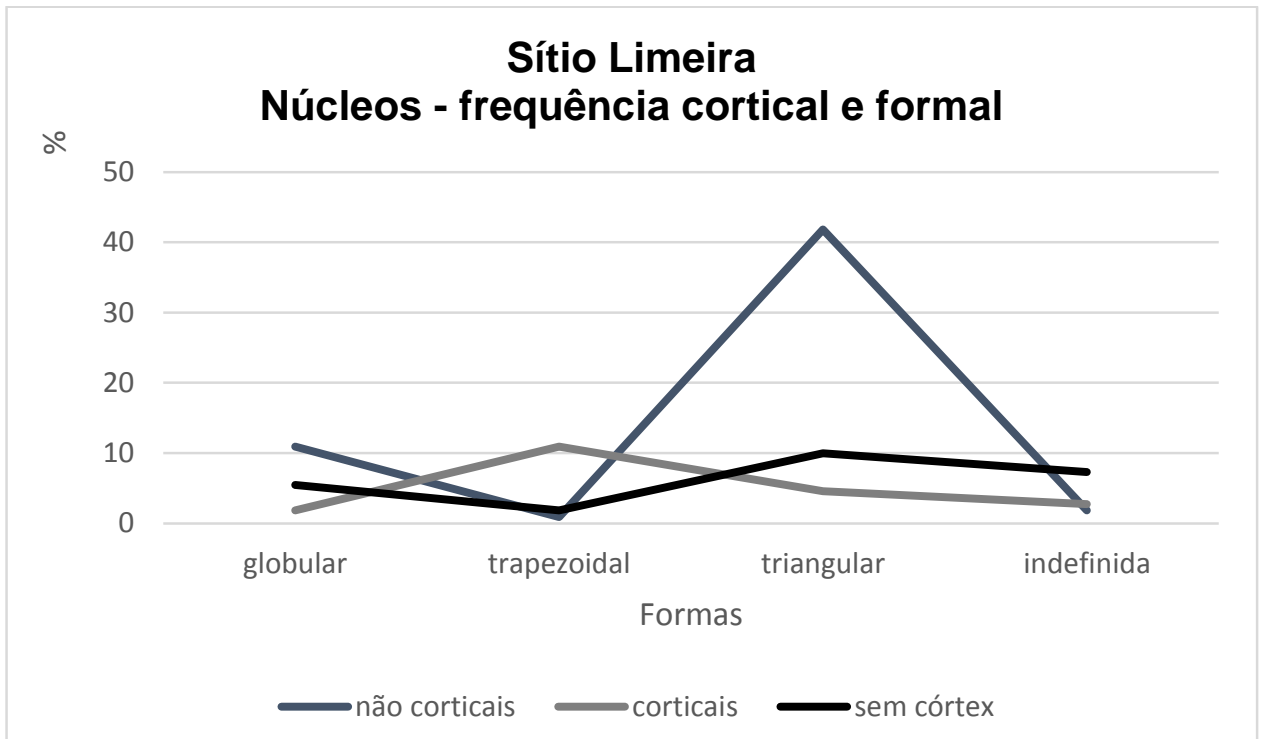

Gráfico 4.7: Frequência de núcleos com relação aos aspectos corticais e formais.

Conforme se pode observar no quadro 4.20 e no gráfico 4.7, há o predomínio de núcleos não corticais na amostra ${ }^{29}$. As peças em forma triangular não corticais são as mais abundantes $(41,82 \%)$, seguidas dos núcleos globulares não corticais $(10,90 \%)$ e das peças trapezoidais corticais $(10,90 \%)$. As peças menos representativas são os núcleos em forma trapezoidal não corticais.

Os núcleos corticais possuem como maiores representantes as peças em forma trapezoidal, seguidas das triangulares $(4,54 \%)$ com menor incidência de núcleos globulares (1,81\%).

Os núcleos sem nenhum córtex apresentaram com maior frequência as peças triangulares $(10 \%)$, seguida das que possuem forma indefinida $(7,27 \%)$ e das globulares $(5,45 \%)$. As peças que ocorreram em menor número foram as trapezoidais; $1,81 \%$ da amostra total de núcleos.

Outra análise interessante é de aproveitamento da matéria prima, relacionandose os diferentes tipos de núcleo ao fato de terem sido esgotados ou não. Núcleos

\footnotetext{
${ }^{29}$ Núcleos não corticais são os que apresentam menos de 50\% de córtex em sua superfície (MORAIS, 1987).
} 
esgotados são núcleos dos quais não é possível mais realizar a retirada de lascas. Os resultados quanto ao esgotamento ou não dos núcleos coletados no sítio Limeira estão expostos no quadro a seguir:

Quadro 4.22: Quantidade e frequência de núcleos esgotados e não esgotados.

\begin{tabular}{|c|cc|cc|}
\hline Tipos de núcleo & \multicolumn{2}{|c|}{ Esgotados } & \multicolumn{2}{c|}{ Não esgotados } \\
& № de peças / frequência & № de peças / frequência \\
\hline Seixo & \multicolumn{5}{|c|}{52} & $59,77 \%$ & 35 & $40,23 \%$ \\
\hline Bloco & 0 & $0 \%$ & 33 & $100 \%$ \\
\hline
\end{tabular}

É interessante notar no quadro 4.21, que dentre os diferentes tipos de núcleo, nenhum dos blocos é esgotado, e que, consultando o quadro 4.15, dos 33 blocos encontrados no sítio Limeira, 21 são corticais, o que representa 63,63\%. Além disso, esses blocos corticais apresentam apenas um único plano de percussão e apenas uma cicatriz de retirada, ou seja, o artesão se utilizava da peça, mas episódios de desistência deveriam ser frequentes e logo as mesmas eram descartadas. Enquanto isso, do total de 87 núcleos oriundos de seixos, 59,77\% são esgotados.

Prous (1986/1990) observam que "uma frequência significativa de núcleos esgotados é geralmente ligada à raridade de matéria prima na região, ou à inexistência de procura específica de determinado padrão de lasca." Tal afirmação, aplicada ao caso do sítio Limeira e associada aos dados apresentados, sugere que havia certa preferência pela utilização de seixos de quartzo na manufatura dos artefatos líticos. Provavelmente, os seixos não eram escassos, mas, por outro lado, não havia busca por lascas padronizadas, o que permitia aos artesãos a utilização dos núcleos (mais propensos à debitagem) para obtenção de lascas até o seu esgotamento.

Além disso, analisando-se comparativamente os núcleos de seixos com núcleos oriundos de blocos, os primeiros possuem arranjo cristalino mais organizado, o que melhora substancialmente a aptidão de lascamento, enquanto os demais possuem em sua estrutura cristais mal formados, dificultando a obtenção de lascas próprias para a utilização. 


\section{Análise de lascas:}

O estudo das lascas também é extremamente importante dentro de uma análise tecnológica de uma indústria lítica. Para isso, foram considerados dados de dimensões, peso, características dos talões e traços de utilização, se possível.

Conforme já citado através da observação de Prous (1986/1990), o quartzo, devido a sua alta dureza e baixa tenacidade, produz lascas com bordos muito cortantes, já aptos para a utilização, o que pôde ser observado no sítio Limeira.

Dessa forma, para a realização das medidas de comprimento, largura e espessura foram tomadas as medidas, sempre que possível, em relação ao eixo de debitagem. Como resultado, obteve-se que as dimensões das lascas coletadas no sítio Limeira variam entre 11 e $72 \mathrm{~mm}$ de comprimento, 8 e $51 \mathrm{~mm}$ de largura e 3 e $39 \mathrm{~mm}$ de espessura. A maior lasca mede $72 \times 51 \times 36$ e pesa $334,44 \mathrm{~g}$, e a menor, $11 \times 11 \times 9$ e pesa $3,20 \mathrm{~g}$.

O quadro abaixo e os gráficos 4.8, 4.9 e 4.10 apresentam as dimensões das lascas em relação aos respectivos números de peças com intervalos de $5 \mathrm{~mm}$ entre comprimento e largura e de $2 \mathrm{~mm}$ em relação à espessura:

Quadro 4.23: Dimensões das lascas do sítio Limeira.

\begin{tabular}{|c|c|c|c|c|c|}
\hline $\begin{array}{c}\text { Comprimento } \\
(\mathrm{mm})\end{array}$ & $\mathrm{n}^{\circ}$ de peças & $\begin{array}{c}\text { Larg. } \\
(\mathrm{mm})\end{array}$ & № de peças & $\begin{array}{c}\text { Espessura } \\
(\mathrm{mm})\end{array}$ & № de peças \\
\hline $0-5$ & 0 & $0-5$ & 0 & $0-2$ & 0 \\
\hline $6-10$ & 0 & $6-10$ & 16 & $3-4$ & 59 \\
\hline $11-15$ & 53 & $11-15$ & 128 & $5-6$ & 138 \\
\hline $16-20$ & 112 & $16-20$ & 128 & $7-8$ & 85 \\
\hline $21-25$ & 85 & $21-25$ & 64 & $9-10$ & 21 \\
\hline $26-30$ & 59 & $26-30$ & 26 & $11-12$ & 16 \\
\hline $31-35$ & 42 & $31-35$ & 26 & $13-14$ & 26 \\
\hline $36-40$ & 32 & $36-40$ & 16 & $15-16$ & 26 \\
\hline $41-45$ & 5 & $41-45$ & 0 & $17-18$ & 5 \\
\hline $51-55$ & 11 & $51-55$ & 11 & $\ldots$ & 0 \\
\hline $56-60$ & 5 & $56-60$ & 0 & $35-36$ & 5 \\
\hline $61-65$ & 0 & $61-65$ & 0 & $37-38$ & 0 \\
\hline $66-70$ & 0 & $66-70$ & 0 & $39-40$ & 5 \\
\hline $71-75$ & 5 & $71-75$ & 0 & - & - \\
\hline
\end{tabular}




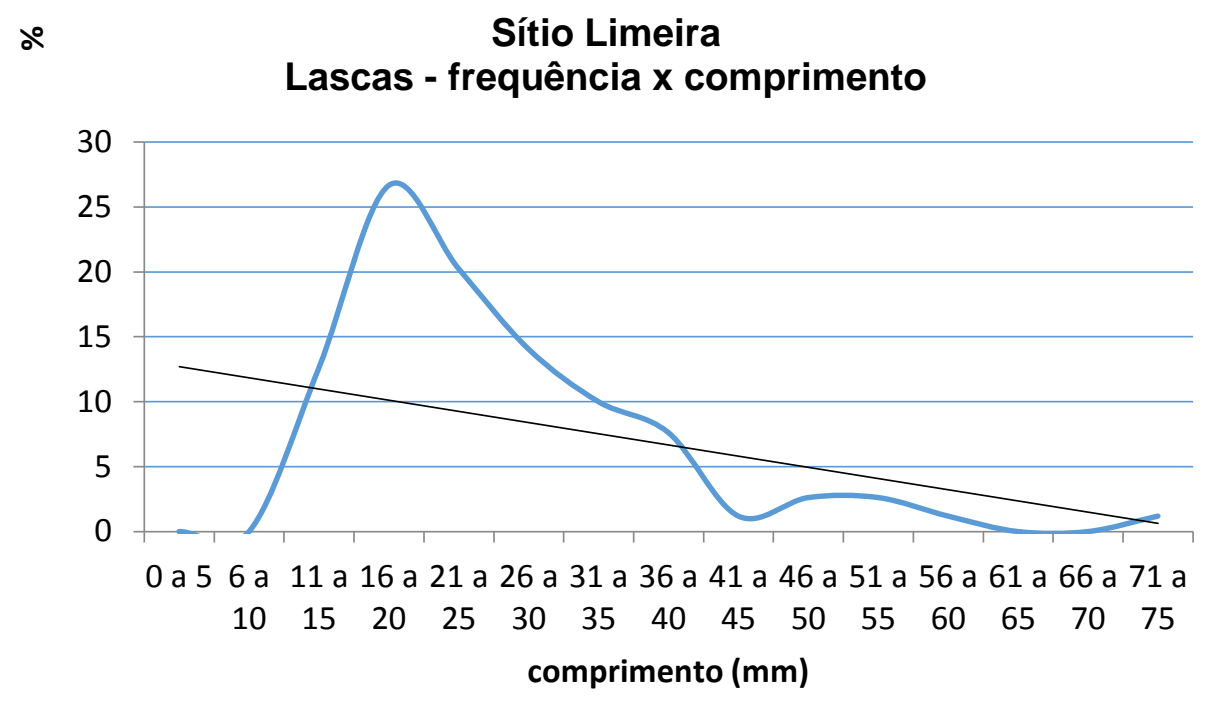

Gráfico 4.8: Relação entre frequência e comprimento das lascas do sítio Limeira.

Observando os dados expostos no quadro 4.22 e no gráfico 4.8, pode-se concluir que embora o comprimento varie entre 11 e $75 \mathrm{~mm}$, a maioria das lascas possui comprimentos entre 16 e $25 \mathrm{~mm}$, representando 46,91\% da amostra, com tendência a diminuir a sua ocorrência em valores maiores que esse.

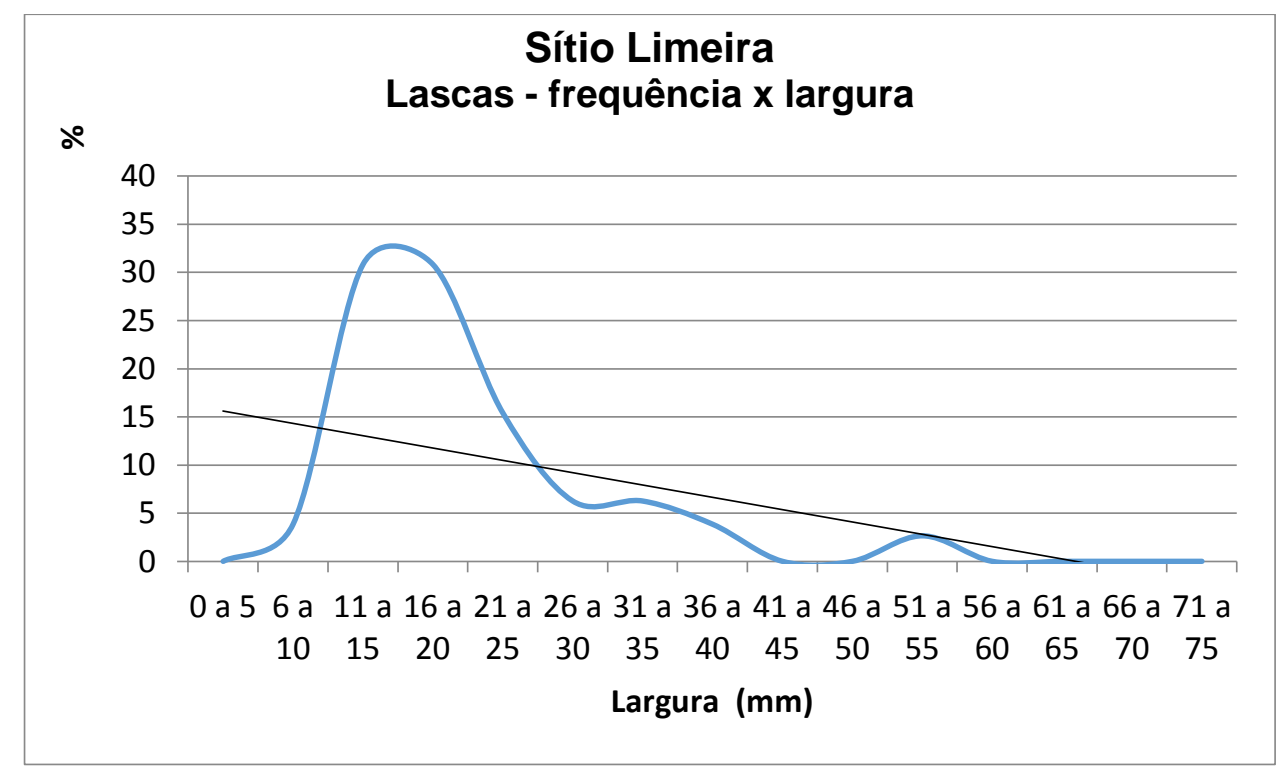

Gráfico 4.9: Relação entre frequência e largura das lascas do sítio Limeira.

Combinando os dados do quadro 4.22 e do gráfico 4.9, pode-se observar que a largura das lascas varia entre 6 e $55 \mathrm{~mm}$, mas a maior parte das lascas possui 
largura entre 11 e $20 \mathrm{~mm}$, o que representa $61,68 \%$ da amostra, com tendência a diminuir a frequência de peças à medida que atinge larguras maiores.

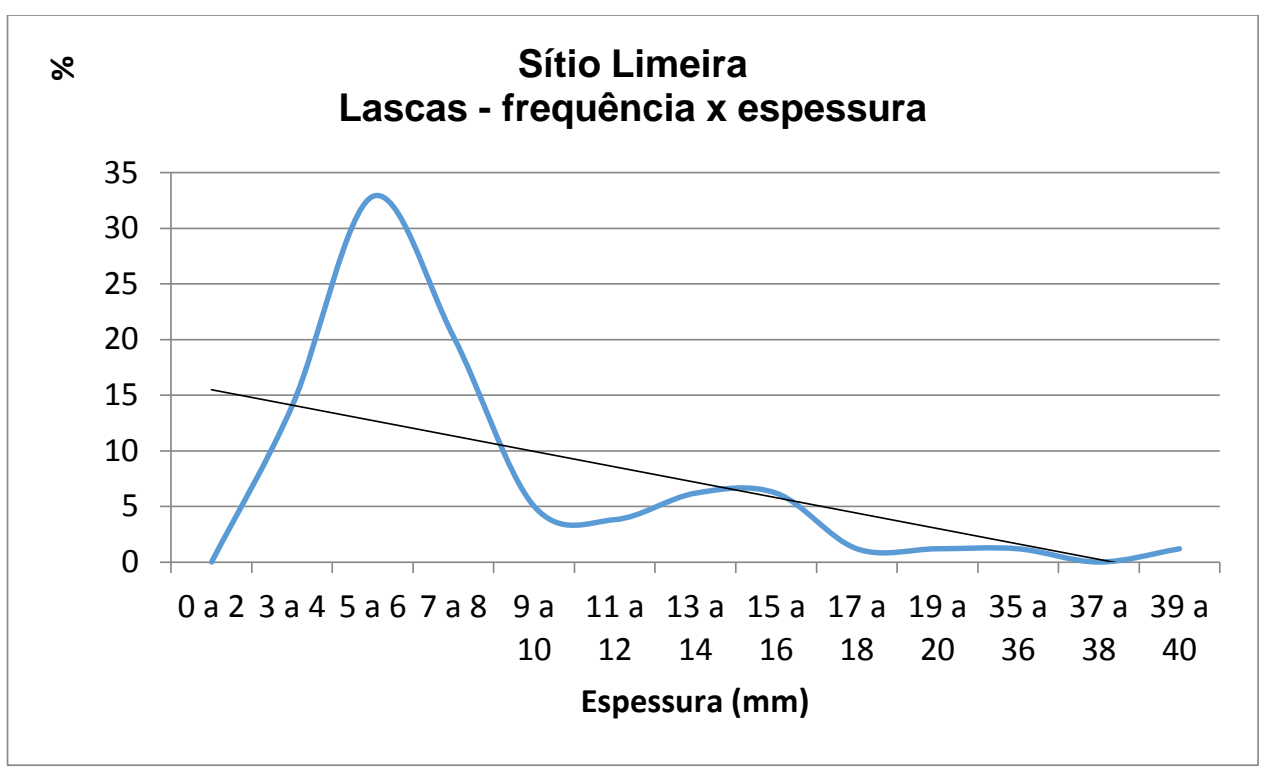

Gráfico 4.10: Relação entre frequência e espessura das lascas do sítio Limeira.

De acordo com os dados expostos no quadro 4.22 e evidenciados no gráfico 4.10, pode-se observar que a amostra possui lascas com espessuras entre 3 e $40 \mathrm{~mm}$, e a maioria das lascas possui entre 5 e $8 \mathrm{~mm}(53,1 \%)$, tendendo à diminuição da quantidade de peças à medida que aumenta o valor da espessura.

Através da combinação dos dados acima, pode-se concluir que as lascas coletadas no sítio Limeira possuem dimensões reduzidas. Diante disso, conforme Bordes (1947), o tamanho da lasca é determinado pelo peso do percutor; ou seja, se o percutor for leve, as lascas serão pequenas. No sítio Limeira a maior parte dos percutores encontrados são seixos de quartzo, exceto por 1 peça de granito e 3 de basalto, sendo seus pesos:

- 7 percutores de quartzo - entre 91,65 e 166,15g;

- 3 percutores de basalto - entre 289,54 e $378 \mathrm{~g}$;

- 1 percutor de granito - $277,2 \mathrm{~g}$.

Como se pode observar, os percutores são leves, o que condiz com os resultados encontrados em relação às lascas. 
Outro fator importante a ser considerados é a relação entre comprimento e largura ( $\mathrm{CxL}$ ), que tem como base Morais (2007), que adaptou os critérios classificatórios para produtos de debitagem propostos por Leroi-Gourhan. De acordo com Morais (2007) as lascas devem ser classificadas conforme descrito abaixo:

$<1,0$ - muito larga

$<1,5$ - quase longa

$<2,0$ - longa

$>2,0$ - laminar

Os resultados estão expostos no quadro a seguir:

Quadro 4.24: Relação entre comprimento e largura das lascas do sítio Limeira.

\begin{tabular}{|c|c|c|}
\hline $\mathrm{C} \times \mathrm{L}$ & № de peças & Porcentagem (\%) \\
\hline$<1$ & 97 & 21,41 \\
\hline$<1,5$ & 201 & 44,37 \\
\hline$<2$ & 120 & 26,50 \\
\hline$>2$ & 35 & 7,72 \\
\hline Total & 453 & 100 \\
\hline
\end{tabular}

Como se pode observar, os resultados do índice $C \times \mathrm{L}$ expostos no quadro 4.23 demonstram que a maioria das lascas do sítio Limeira $(44,37 \%)$ são consideradas quase longas, seguidas das longas $(26,50 \%)$ e das muito largas $(21,41 \%)$. As menos representativas são as lascas laminares, 7,72\% da amostra. Assim, as lascas do sítio Limeira são desde quase longas a muito largas.

Considerando que, conforme citado anteriormente, para medir as dimensões foram utilizadas as lascas inteiras e que o quartzo é um mineral de baixa tenacidade, este resultado está dentro do esperado. Além disso, segundo Bordes (1947), o quartzo produz maus percutores, o que, associado às próprias características desse mineral quanto à aptidão ao lascamento e à presença de núcleos esgotados globulares, sugere a produção de lascas irregulares, mesmo que tenham sido encontrados também percutores de granito e basalto.

No que refere às lascas com evidentes traços de utilização, a relação entre comprimento e largura produziu os seguintes resultados: 
Quadro 4.25: Relação entre comprimento e largura das lascas utilizadas do sítio Limeira.

\begin{tabular}{|c|c|c|c|}
\hline $\mathrm{C} \times \mathrm{L}$ & $\begin{array}{c}\text { No de peças } \\
\text { utilizadas }\end{array}$ & $\begin{array}{c}\text { Frequência parcial } \\
(\%)\end{array}$ & $\begin{array}{c}\text { Frequência total } \\
(\%)\end{array}$ \\
\hline$<1$ & 30 & 63,83 & 6.62 \\
\hline$<1,5$ & 0 & 0 & 0 \\
\hline$<2$ & 17 & 36,17 & 3,75 \\
\hline$>2$ & 0 & 0 & 0 \\
\hline Total & 47 & 100 & 10,37 \\
\hline
\end{tabular}

Os dados do quadro 4.24 demonstram que das 47 lascas consideradas utilizadas representam $10,37 \%$ do total da amostra, e que a maioria pode ser classificada como muito larga (63.83\%) e o restante é constituído de lascas longas (36,17\%). É interessante ressaltar que dentre as 30 lascas muito largas, 21 são lascas iniciais e que todas as peças longas (17) foram identificadas como lascas que podem ter sido utilizadas como furadores. Em adição, uma das peças (Lim 0108) possui características interessantes, pois além de ser muito larga (índice $C x L=0,76$ ), possui uma das extremidades pontiaguda, o que sugere que se trata de uma lasca de múltipla função, para raspar e perfurar.

Quanto à análise de estado de superfície, as lascas foram divididas entre as que apresentam córtex: ausente, maior que $50 \%$, ou menor que $50 \%$. Os resultados estão no quadro abaixo:

Quadro 4.26: Estado de superfície das lascas do sítio Limeira.

\begin{tabular}{|c|c|c|}
\hline Córtex & № de peças & Porcentagem (\%) \\
\hline ausente & 165 & 36,42 \\
\hline$>50 \%$ & 74 & 16,34 \\
\hline$<50 \%$ & 214 & 47,24 \\
\hline Total & 453 & 100 \\
\hline
\end{tabular}

Como se pode observar no quadro $4.25,47,24 \%$ das lascas possuem menos de $50 \%$ de superfície cortical, enquanto $36,42 \%$ não apresentam córtex. As lascas corticais representam $16,34 \%$ da amostra, com 74 peças. Dentre elas, 21 lascas são iniciais.

Outro fator interessante a ser considerado é a relação existente entre os núcleos e as lascas corticais e iniciais. Os resultados estão dispostos nos gráficos $4.11 \mathrm{e}$ 4.12 a seguir: 


\section{Relação entre núcleos e lascas corticais}

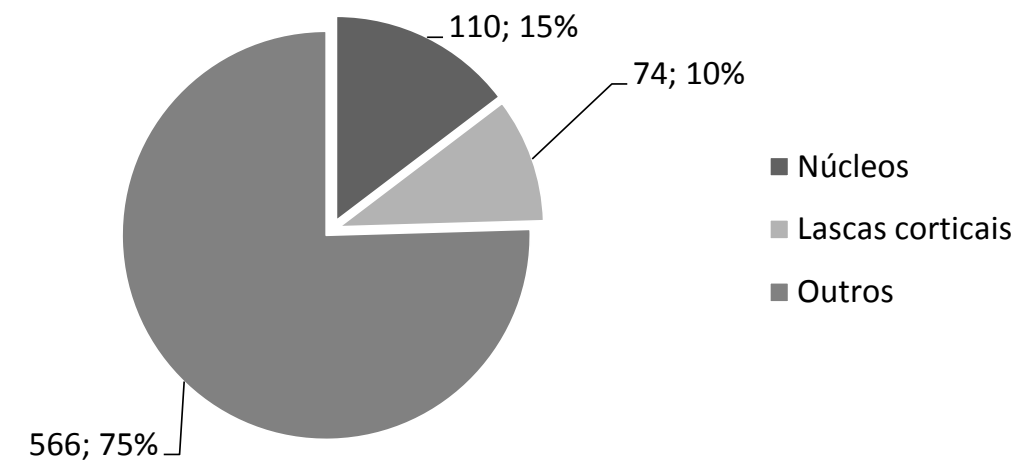

Gráfico 4.11: Relação entre núcleos e lascas corticais do sítio Limeira.

\section{Relação entre núcleos e lascas iniciais}

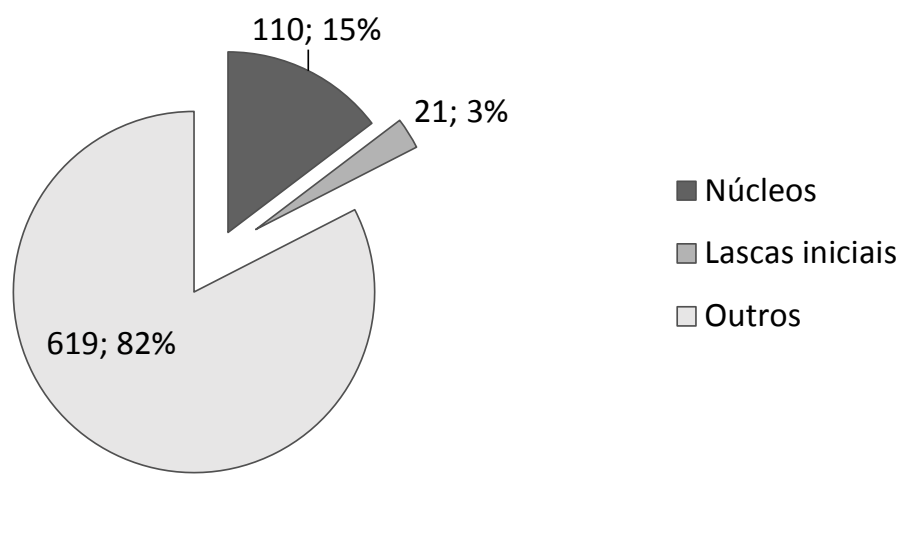

Gráfico 4.12: Relação entre núcleos e lascas iniciais do sítio Limeira.

Conforme exposto nos gráficos, a relação entre núcleos e lascas corticais é de praticamente 1,5:1 e a de núcleos e lascas iniciais é de praticamente de 5:1. Além disso, comparando esses resultados com o quadro 4.15, do total de 110 núcleos, 25 são núcleos corticais, o que representa $22,72 \%$ do total de núcleos.

Em relação à análise de talão, Morais (1987) ressalta a sua importância, observando que esta pode revelar o domínio sobre a técnica de lascamento por parte do artesão, além de outros aspectos tecnológicos ligados ao processo de manufatura das peças. Prous (1986/1990), por exemplo, destaca que "a forma e o comprimento das lascas podem, até certo ponto, ser controlados pela forma de percussão e pela preparação do núcleo". 
Assim, para uma melhor organização, Morais (1987) sugere a divisão e classificação dos talões em: cortical, liso (plano, côncavo e convexo), facetado (diedro, retilíneo, côncavo e convexo), linear (geralmente associado a percutores macios, como chifre, madeira e osso) e puntiforme (geralmente associado à percussão indireta).

Para a classificação e contagem dos tipos de talão foram consideradas as lascas inteiras, já que a ocorrência de fragmentos proximais foi mínima. Os resultados estão expostos nos quadros:

Quadro 4.27: Relação entre os diferentes tipos de talão e o número de lascas.

\begin{tabular}{|l|l|l|}
\hline Tipo de talão & No de peças & Porcentagem (\%) \\
\hline Liso-plano & 423 & 93,4 \\
\hline cortical & 29 & 6,6 \\
\hline total & 452 & 100 \\
\hline
\end{tabular}

De acordo com o quadro, as lascas do sítio Limeira apresentam talões do tipo liso-plano ou cortical. Os talões lisos-planos representam 93,4\% da amostra, o que, segundo Morais (2007) não significa ausência de preparo para o lascamento, mas que pode ter sido preparado por retiradas objetivando a "supressão da cornija deixada por contra-bulbos de retiradas anteriores realizadas durante a fase preparatória do núcleo." Já os talões corticais estão presentes em 6,6\% das lascas, condizendo com a quantidade de lascas corticais, que correspondem a $16,34 \%$ do total de lascas recuperadas.

No estudo das lascas do sítio Limeira também foram incluídas análises dos ângulos de chasse e dos ângulos de lascamento. De acordo com Morais (2007), esses dados estão diretamente ligados à relação existente entre comprimento e largura das lascas, lâminas, lamelas e estilhas de lascamento, e podem auxiliar na compreensão a respeito das dimensões de tais produtos de debitagem.

Conforme Morais (2007), o ângulo de chasse é o que se forma entre o plano do talão e a face externa da peça, e o ângulo de lascamento é aquele que se forma entre o plano do talão e a face interna da peça. Morais (2007) ainda observa que quando o ângulo de chasse é obtuso, há a obtenção de produtos mais alongados.

As peças analisadas foram divididas quanto ao tipo de talão. Os resultados relacionados às lascas de talão liso-plano podem ser observados abaixo: 
Quadro 4.28: Lascas com talão liso-plano - relação entre o índice C x L e os ângulos do talão.

\begin{tabular}{|c|c|c|c|c|c|c|c|c|c|}
\hline \multicolumn{2}{|l|}{ Lascas com talão liso-plano } \\
\multicolumn{2}{|l|}{ ângulo } & \multicolumn{2}{l|}{$\begin{array}{l}\text { Muito larga } \\
\text { Quant./ (\%) }\end{array}$} & \multicolumn{2}{c|}{$\begin{array}{c}\text { Quase longa } \\
\text { Quant./ (\%) }\end{array}$} & \multicolumn{2}{c|}{$\begin{array}{c}\text { Longa } \\
\text { Quant./ } \%)\end{array}$} & $\begin{array}{c}\text { Laminar } \\
\text { Quant./ (\%) }\end{array}$ \\
\hline Int. & $<90^{\circ}$ & 0 & 0 & 5 & 1,10 & 11 & 2,42 & 5 & 1,10 \\
\hline Int. & $\geq 90^{\circ}$ & 85 & 18,76 & 138 & 30,46 & 112 & 24,72 & 27 & 5,96 \\
\hline Ext. & $<90^{\circ}$ & 75 & 16,55 & 16 & 3,53 & 16 & 3,53 & 0 & 0 \\
\hline Ext. & $\geq 90^{\circ}$ & 21 & 4,63 & 155 & 34,21 & 112 & 24,72 & 4 & 4,63 \\
\hline Intern $>$ Extern & 32 & 7,06 & 32 & 7,06 & 32 & 32 & 5 & 1,10 \\
\hline Intern $<$ Extern & 16 & 3,53 & 58 & 12,80 & 21 & 4,63 & 11 & 2,42 \\
\hline Intern = Extern & 32 & 7,06 & 48 & 10,59 & 80 & 17,66 & 11 & 2,42 \\
\hline
\end{tabular}

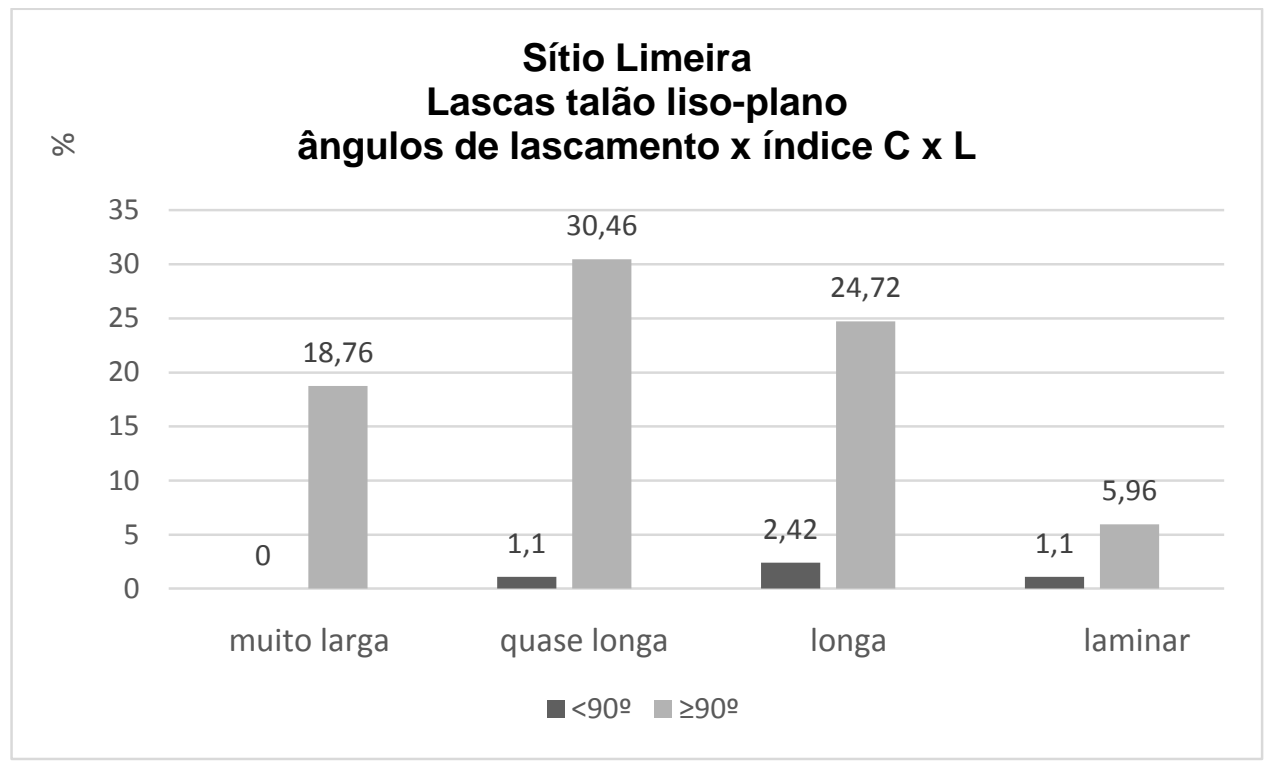

Gráfico 4.13: Frequência entre lascas de talão liso-plano por ângulo de lascamento e índice CxL.

Considerando os dados expostos no quadro 4.27 e no gráfico 4.13, é possível observar que dentre as lascas com talão liso-plano a maioria se encaixa nas categorias quase longa e longa, totalizando ( $55,18 \%$ do total de lascas), seguida das lascas muito largas, que representam $18,76 \%$. Além disso, em todas as categorias há o predomínio de lascas cujos talões apresentam ângulos de lascamento iguais ou superiores a $90^{\circ}$. 


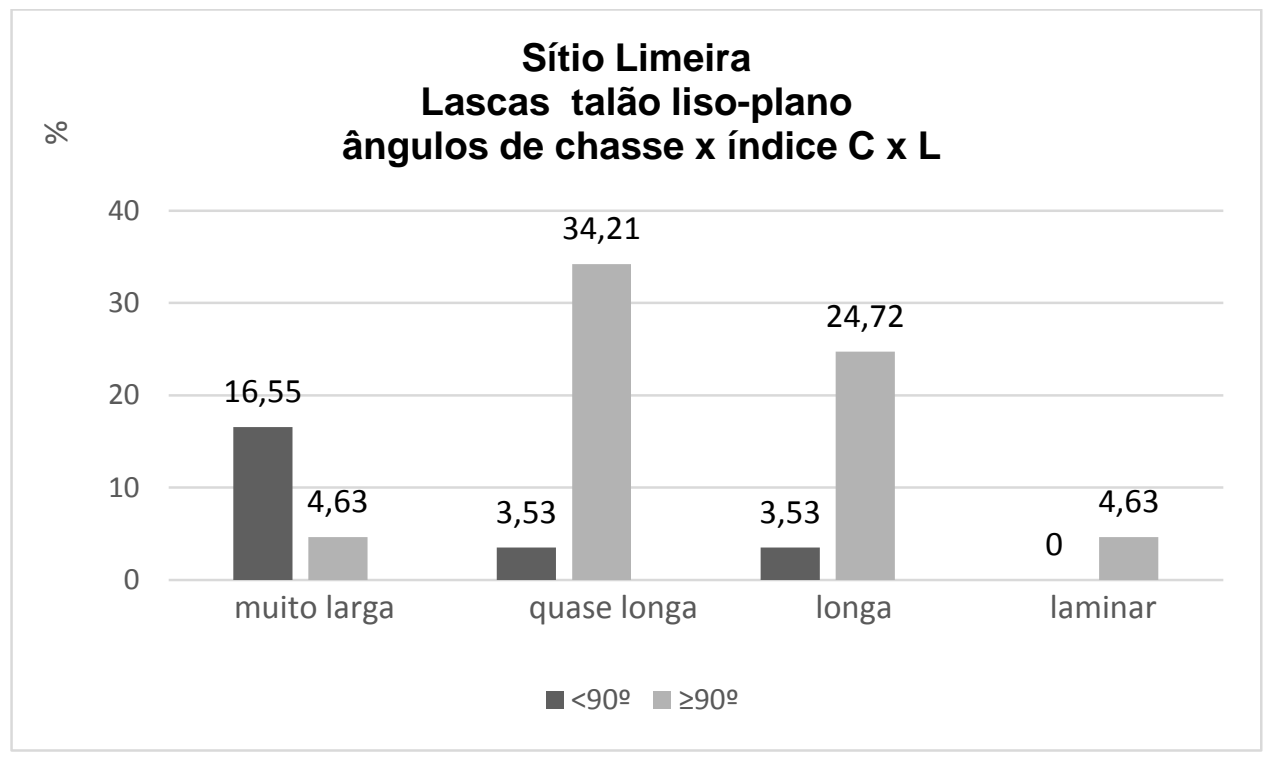

4.14: Frequência entre lascas de talão liso-plano por ângulo de chasse e índice $C \times \mathrm{L}$.

O gráfico 4.14, demonstra que a maior parte das lascas com talão liso-plano são quase longas a longas, representando $58,93 \%$ da amostra de lascas, e que possuem, em sua maioria, ângulos de chasse retos ou obtusos. Além disso, grande parte das lascas muito largas apresentaram ângulos agudos. Tais resultados estão de acordo com as observações de Morais (2007) que afirma que a largura das lascas é inversamente proporcional aos ângulos de chasse.

As mesmas análises acima observadas foram realizadas em relação às lascas de talão cortical. Os resultados estão expostos abaixo:

Quadro 4.29: Lascas com talão cortical - relação entre o índice $C \times L$ e os ângulos do talão.

\begin{tabular}{|c|c|c|c|c|c|c|c|c|c|}
\hline \multicolumn{2}{|c|}{ ângulo $\mathrm{CxL}$} & \multicolumn{2}{|c|}{$\begin{array}{l}\text { Muito larga } \\
\text { Quant./ (\%) }\end{array}$} & \multicolumn{2}{|c|}{$\begin{array}{l}\text { Quase longa } \\
\text { Quant./ (\%) }\end{array}$} & \multicolumn{2}{|c|}{$\begin{array}{c}\text { Longa } \\
\text { Quant./ (\%) }\end{array}$} & \multicolumn{2}{|c|}{$\begin{array}{c}\text { Laminar } \\
\text { Quant./ (\%) }\end{array}$} \\
\hline Int. & $<90^{\circ}$ & 0 & 0 & 0 & 0 & 0 & 0 & 4 & 0,88 \\
\hline Int. & $\geq 90^{\circ}$ & 5 & 1,10 & 9 & 1,98 & 6 & 1,32 & 0 & 0 \\
\hline Ext. & $<90^{\circ}$ & 0 & 0 & 9 & 1,98 & 0 & 0 & 0 & 0 \\
\hline Ext. & $\geq 90^{\circ}$ & 5 & 1,10 & 0 & 0 & 6 & 1,32 & 4 & 0,88 \\
\hline \multicolumn{2}{|c|}{ Intern > Extern } & 0 & 0 & 0 & 0 & 0 & 0 & 0 & 0 \\
\hline \multicolumn{2}{|c|}{ Intern $<$ Extern } & 0 & 0 & 0 & 0 & 0 & 0 & 0 & 0 \\
\hline \multicolumn{2}{|c|}{ Intern = Extern } & 5 & 1,10 & 9 & 1,98 & 6 & 1,32 & 4 & 0,88 \\
\hline
\end{tabular}




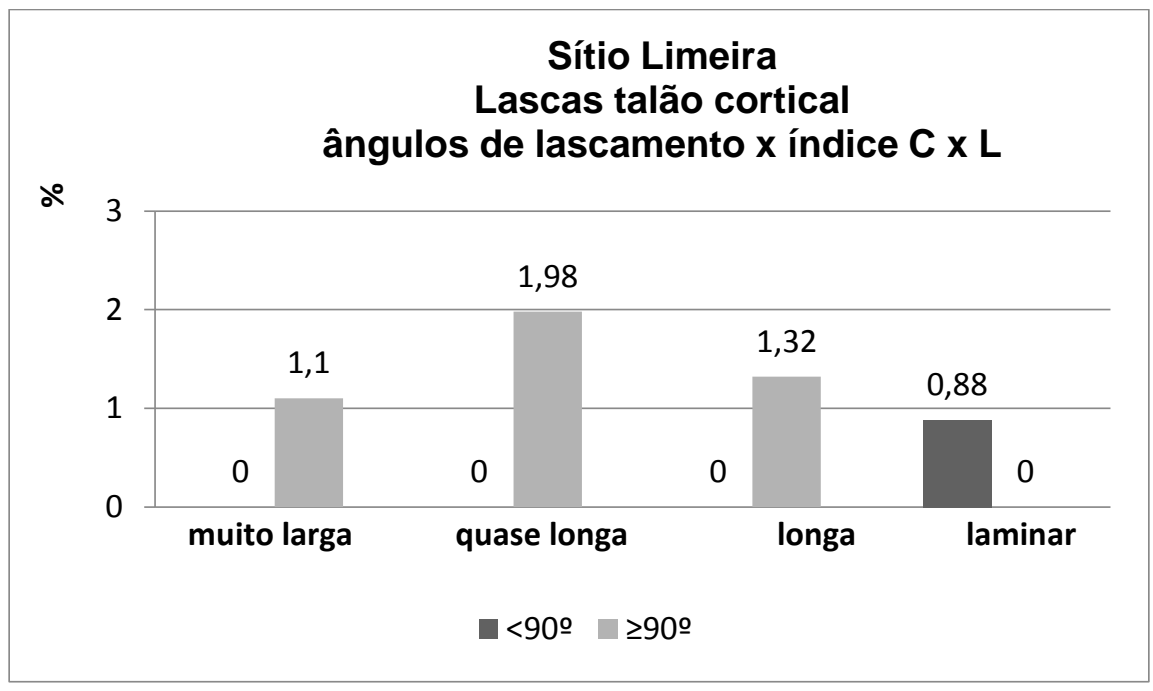

Gráfico 4.15: Frequência entre lascas de talão cortical por ângulo de lascamento e índice C x L.

Considerando os dados expostos no quadro 4.28 e no gráfico 4.15 , pode-se observar que dentre quase todas as categorias correspondentes à relação entre comprimento e largura, as lascas com talão cortical apresentam ângulos internos iguais ou superiores a $90^{\circ 30}$, exceto no caso das lascas laminares, que correspondem a $0,88 \%$ do total de lascas, que apresentaram talão cortical com ângulos inferiores a $90^{\circ}$. Esse dado ressalta a utilização de percutores duros para 0 processo de debitagem (FAGUNDES, 2004), principalmente se associado ao fato de os percutores encontrados no sítio Limeira serem de quartzo (maioria), basalto e granito.

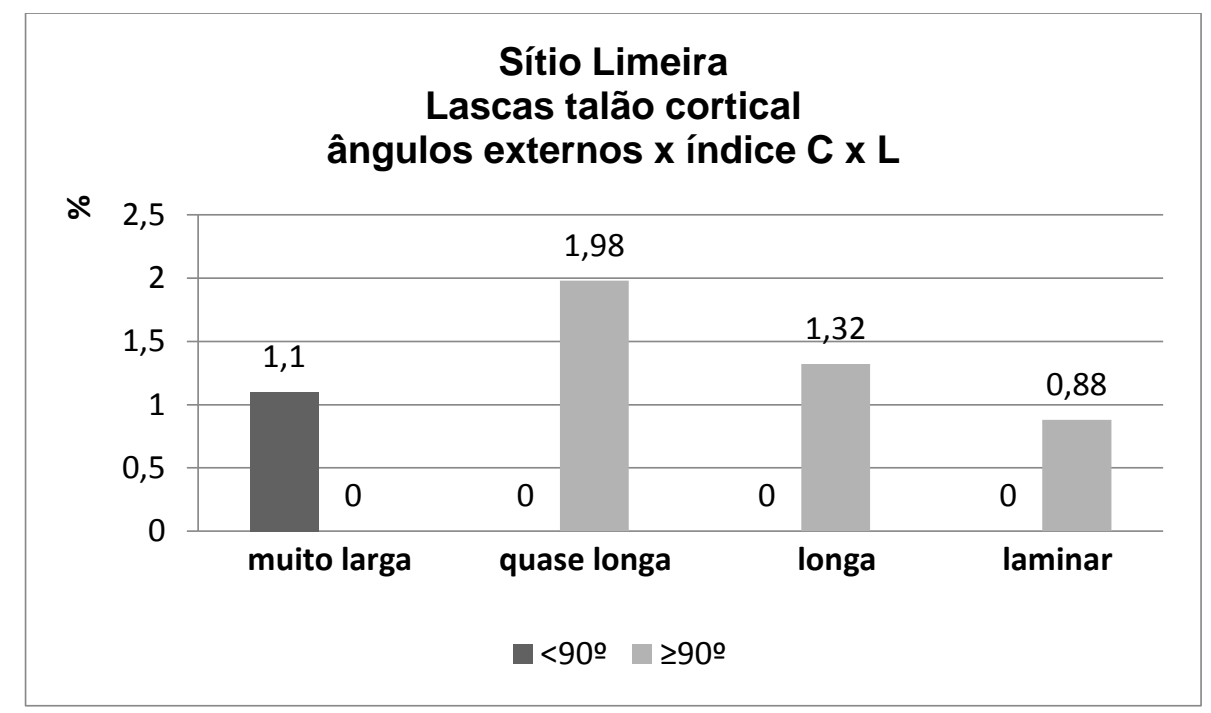

Gráfico 4.16: Frequência entre lascas de talão cortical por ângulo de chasse e índice C x L.

\footnotetext{
${ }^{30}$ Maioria com ângulos de 90․․
} 
De acordo com o gráfico, a maioria das lascas de talão cortical se encaixa na categoria quase longa, correspondendo a $1,98 \%$ do total de lascas, seguida pelas longas (1,32\%). Além disso, é importante observar que as lascas pertencentes às categorias quase longa, longa e laminar possuem ângulo de chasse iguais ou superiores a $90^{\circ}$, enquanto as lascas muito largas apresentam ângulos agudos, o que coaduna com as observações de Morais (2007).

Outro dado interessante é o fato de as lascas corticais classificadas como muito largas estarem relacionadas às lascas iniciais, que são mais arredondadas e indicam o início do processo de debitagem. Além disso, associando aos dados expostos no quadro 4.24, das 30 lascas muito largas que apresentam traços evidentes de utilização coletadas no sítio Limeira, 21 são lascas iniciais, o que sugere a preferência pela utilização de lascas iniciais para a realização de atividades como raspar.

\subsubsection{Análise tipológica:}

Para análise tipológica, a exemplo de Morais (2007), foi necessário selecionar dentre as 750 peças que compõem a indústria lítica do sítio Limeira, as mais significativas, ou seja, as que melhor representavam os diferentes tipos de peças analisadas no decorrer da pesquisa. Assim, elas foram descritas de forma detalhada, com base na ficha tecnotipológica proposta por Morais (1987), acompanhadas de seus respectivos números de identificação e locais de origem. Os resultados estão expostos a seguir: 


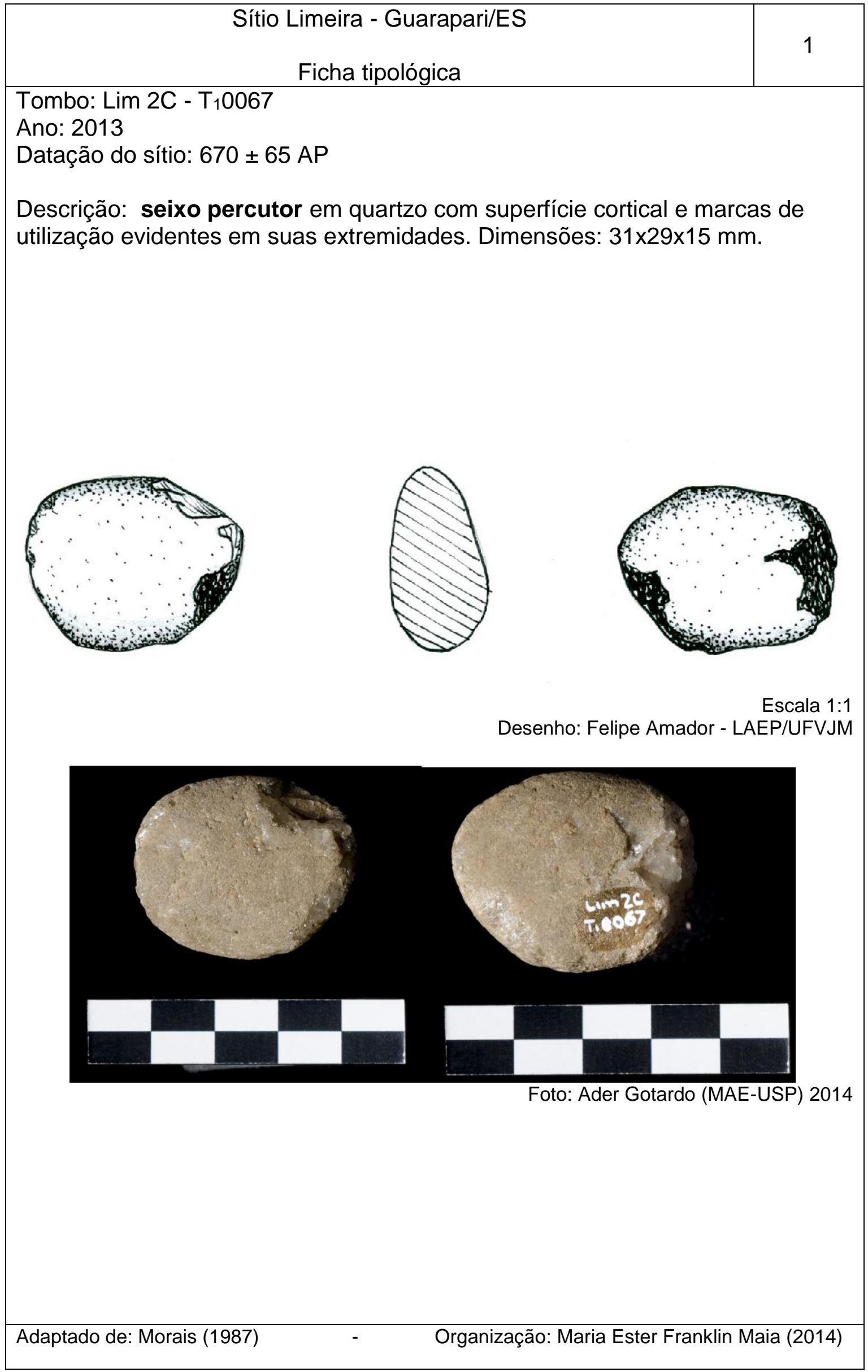




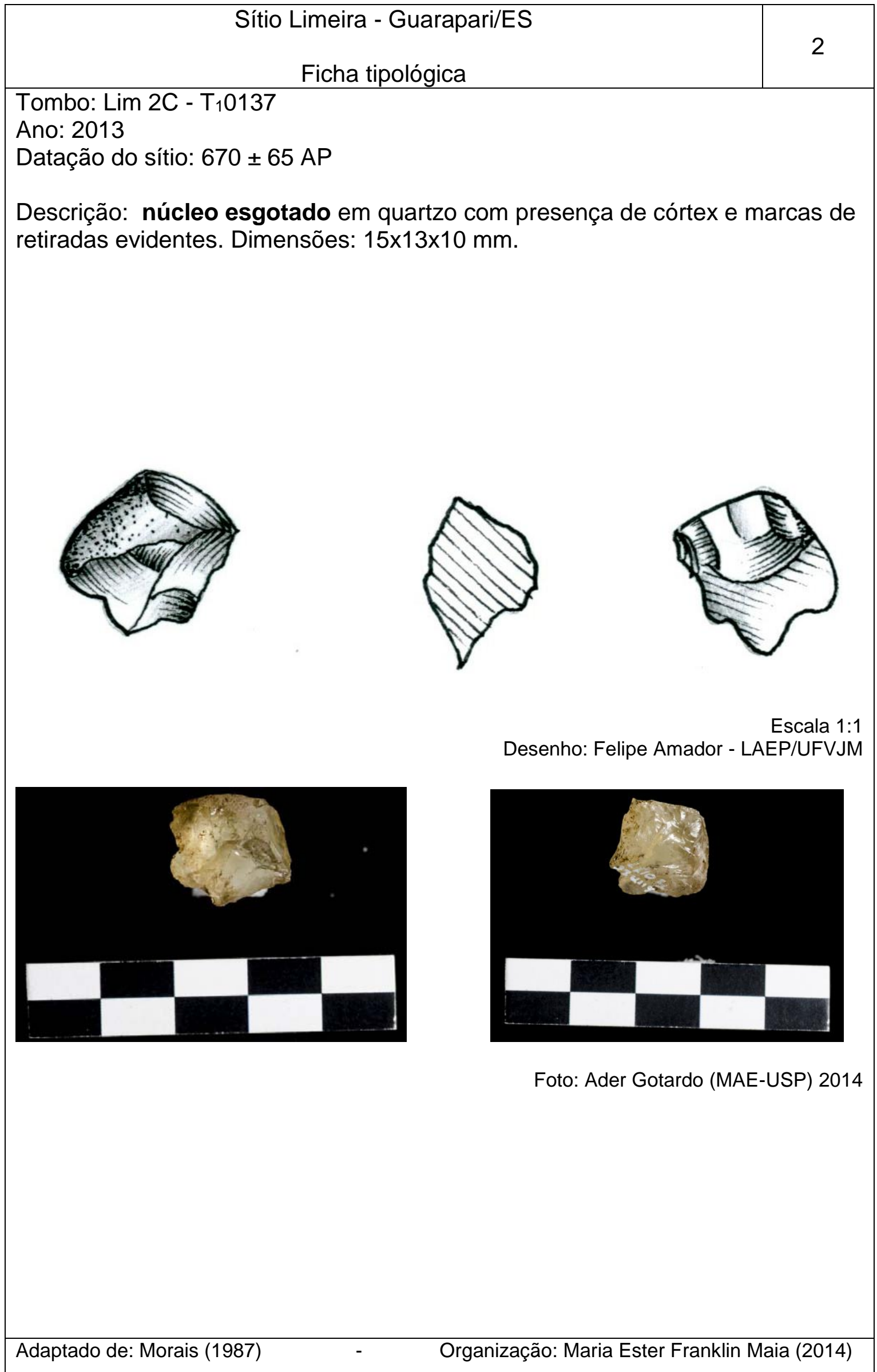




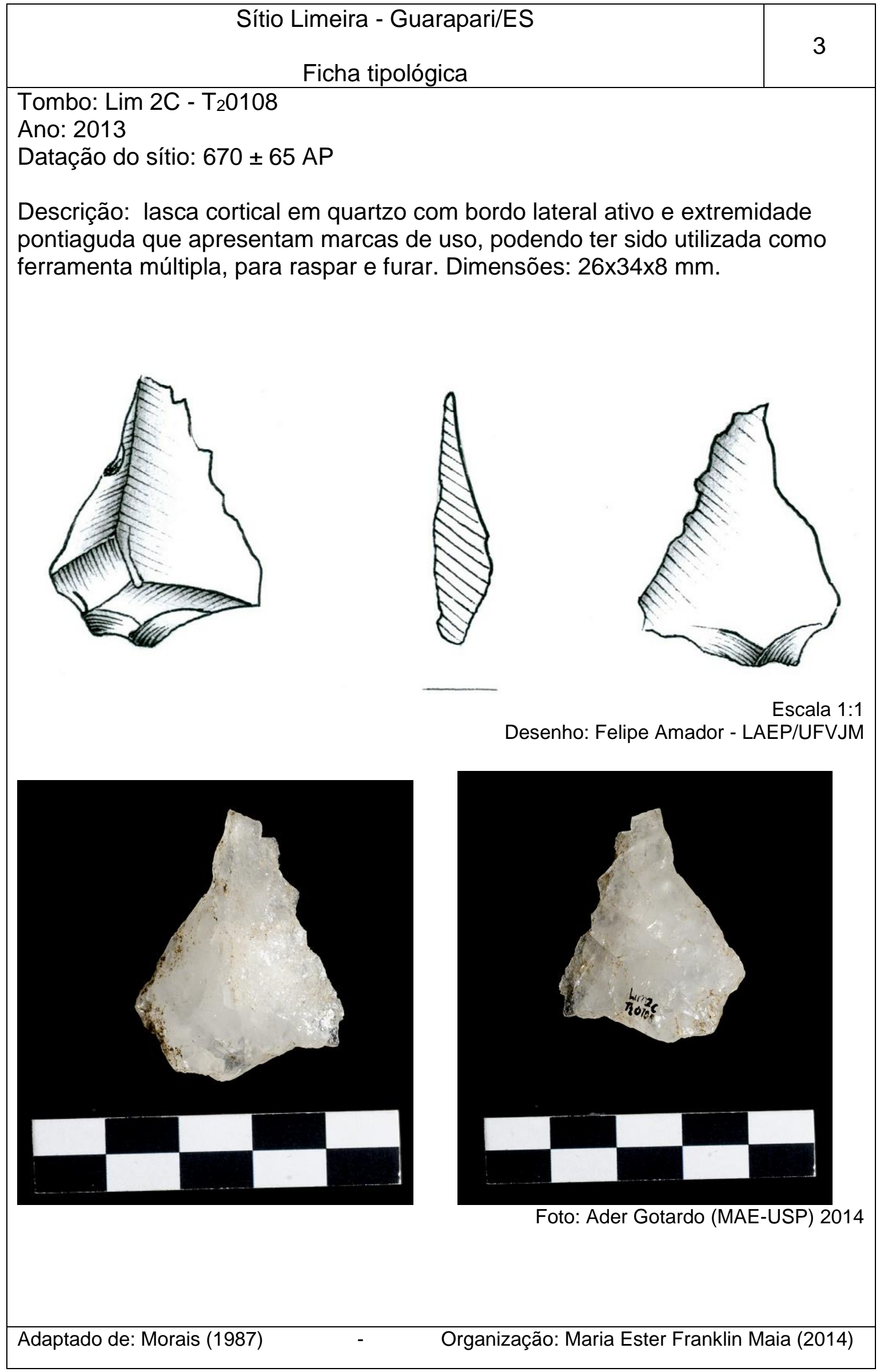




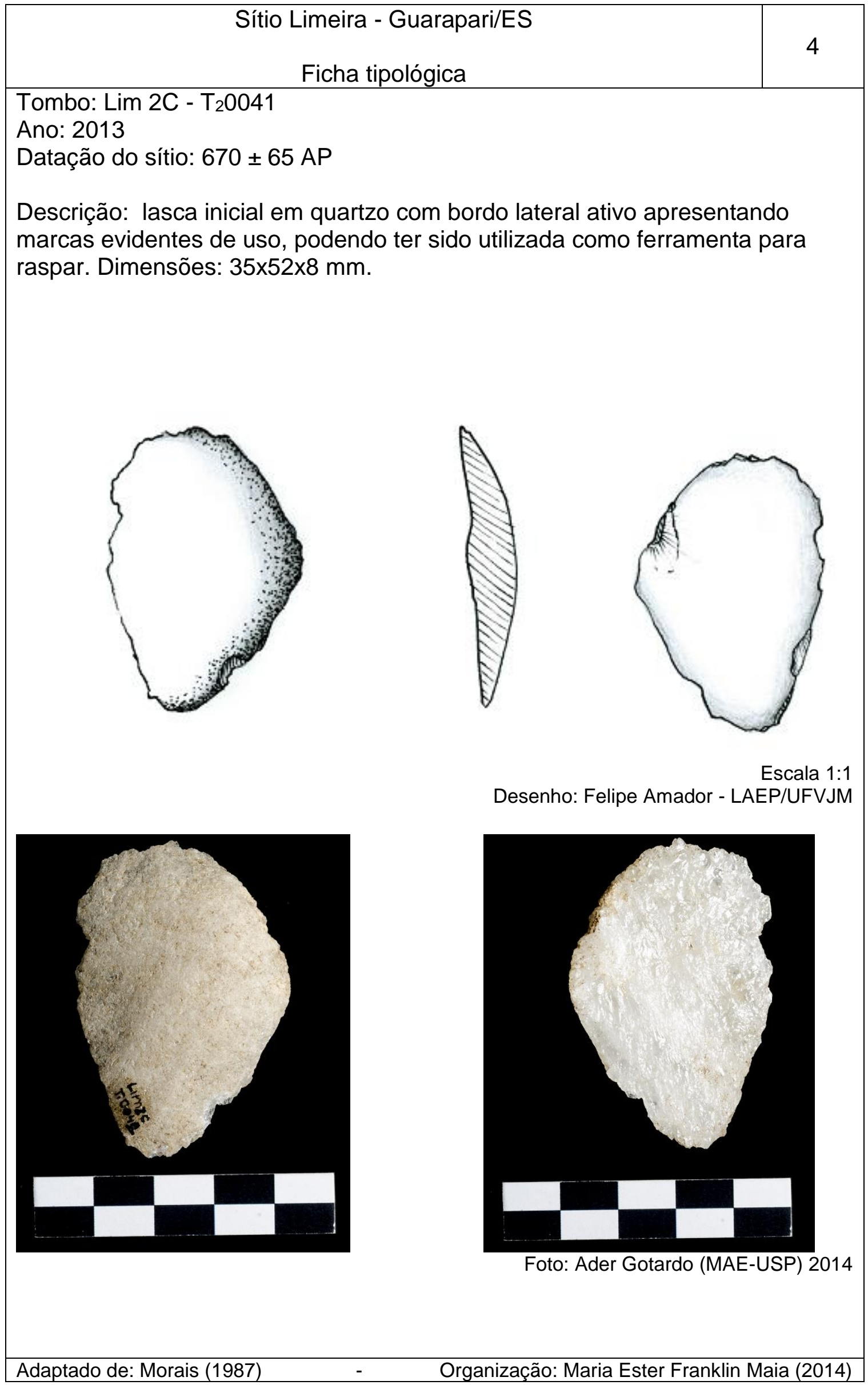




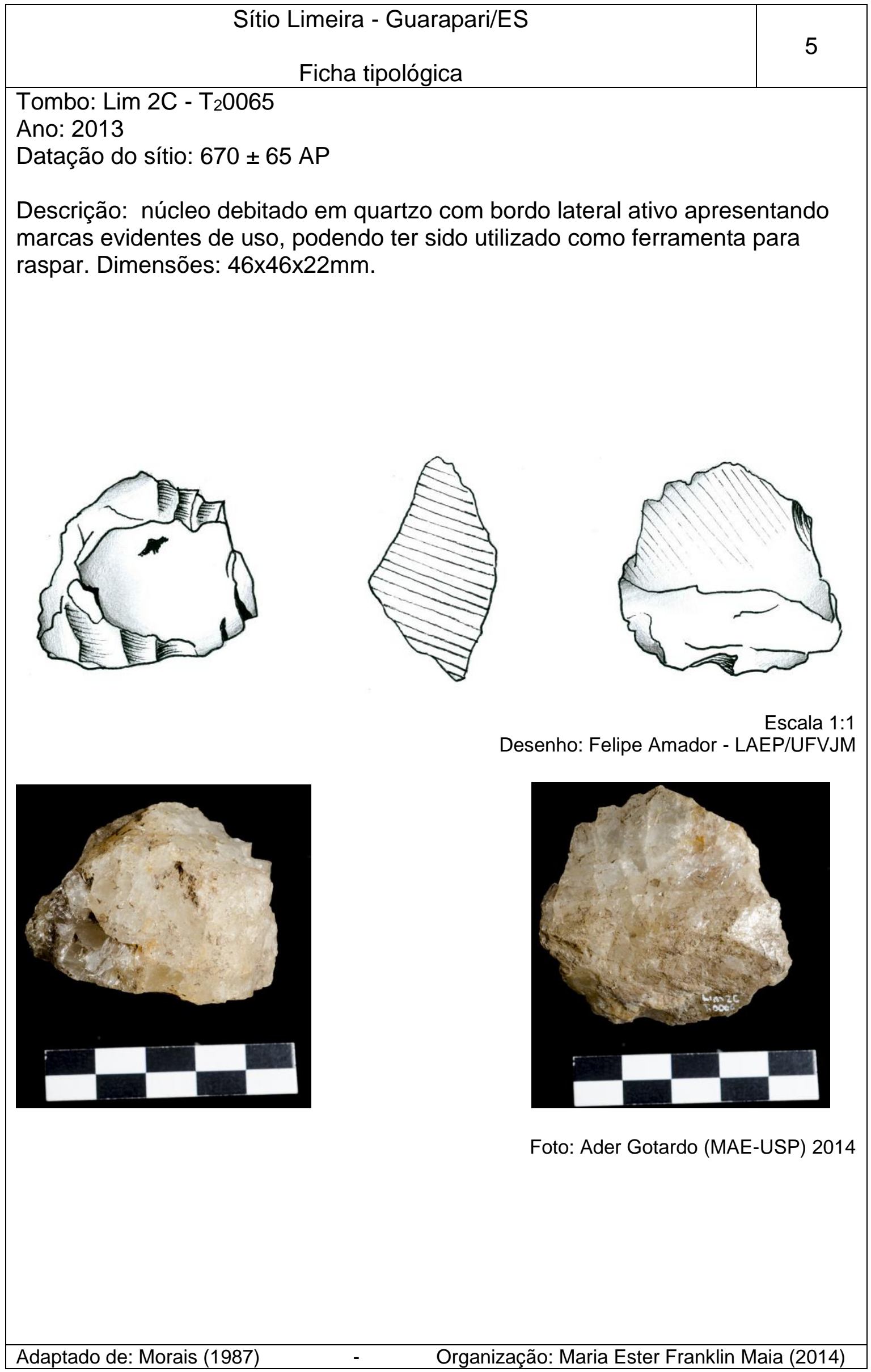




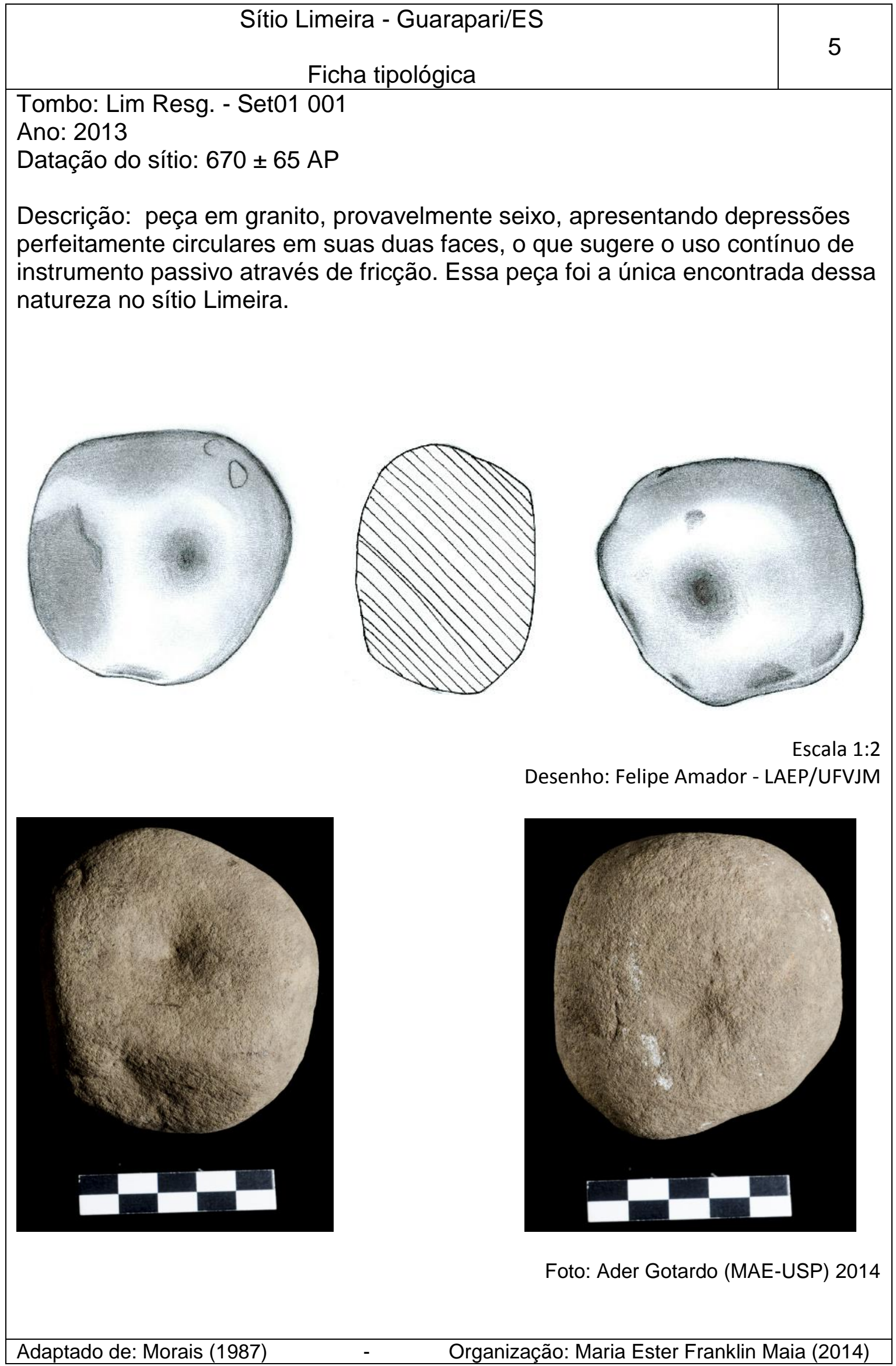




\subsubsection{Os procedimentos da manufatura - a cadeia operatória:}

As análises dos dados expostos em conjunto com as discussões de seus resultados em face aos pressupostos teóricos contidos nas bibliografias utilizadas como base sugerem que:

- a principal matéria prima utilizada no sítio Limeira foi o quartzo na forma de seixos rolados (em quantidade predominante) e de blocos;

- a provável procedência dessa matéria prima está nos seixos rolados oriundos do leito do rio Jabuti, localizado a cerca de $2 \mathrm{~km}$ do sítio Limeira, e nos blocos provenientes de veios de quartzo dos costões rochosos que se encontram a menos de $1 \mathrm{~km}$ de distância (Fig. 2.4 e anexo D).

- os núcleos oriundos de seixos apresentam rede cristalina mais organizada que os núcleos de bloco, o que indica maior aptidão ao lascamento dos primeiros em comparação aos segundos. Além disso, muitos núcleos de seixos apresentaram esgotamento, o que não ocorreu entre os núcleos de bloco, sendo a indústria lítica do sítio Limeira predominantemente sobre seixos de quartzo. Esses dados sugerem uma preferência por parte dos artesãos pela utilização de seixos;

- dentre os núcleos de blocos coletados, 63,63\% são corticais e apresentam apenas um único plano de percussão e apenas uma cicatriz de retirada, o que sugere episódios de desistência e descarte dessas peças.

- a indústria lítica contextualizada do sítio Limeira apresentou núcleos com dimensões reduzidas, leves (o que facilita o seu transporte) e corticais. Além disso, foi observada uma quantidade considerável de lascas corticais e lascas iniciais. Associando-se esses dados aos fatos de a provável área-fonte ser próxima, é possível sugerir que a matéria prima para manufatura das peças líticas a serem utilizadas era transportada pelos habitantes do sítio Limeira desde a área fonte até o seu assentamento, onde era submetida à sequência de redução que deu origem às peças analisadas;

- na trincheira $\mathbf{T}_{1}$, a $8 \mathrm{~m}$ de distância da fogueira e a $2 \mathrm{~m}$ de um dos bolsões malacológicos, foi encontrada a maior concentração de lascas iniciais, núcleos corticais e estilhas, o que sugere que esse era o local onde se realizava 0 processo de debitagem (Fig. 3.7 - Pranchas 1 e 4); 
- todos os percutores coletados são duros, possuem dimensões pequenas e são leves, além de apresentarem traços de utilização somente em suas extremidades, o que sugere que o lascamento era unipolar realizado por percussão direta.

- o fato de o lascamento ser realizado com percutores leves, com tamanho reduzido e a maioria ser em quartzo, associado à existência de quantidade representativa de núcleos globulares, resulta em lascas pequenas e irregulares (BORDES, 1947; CALDARELLI, 1983; MORAIS, 2007), conforme foi observado no sítio Limeira;

- as lascas são as peças que se apresentam em maior número na indústria lítica do sítio Limeira representando $60,40 \%$, o que sugere que a sua obtenção era o principal objetivo do artesão durante o processo de debitagem (PROUS, 1986/1990);

- a maioria das lascas apresentam talão liso-plano e podem ser classificadas como quase longas a longas com ângulos de lascamento iguais ou superiores a $90^{\circ}$. Além disso, as lascas muito largas apresentaram ângulos de chasse agudos (MORAIS, 2007). Tal padronização sugere uma ação proposital do artesão para obter lascas com diferentes características conforme a sua necessidade.

- todas as lascas corticais muito largas, com ângulo de lascamento igual ou superior a $90^{\circ}$ estão diretamente relacionadas a lascas iniciais, que por sua vez, possuem traços evidentes de utilização no bordo lateral, o que sugere a preferência na utilização dessas peças para a realização de atividades como raspar;

- não foram identificadas peças que apresentem retoque, porém as lascas de quartzo possuem naturalmente bordos cortantes aptos para a utilização (PROUS, 1986/1990) e as características de clivagem do quartzo proporcionam uma extremidade aguda, ativa e reforçada (MORAIS, 2007), atendendo às suas necessidades do artesão, como furar, cortar e raspar;

- há a presença de muitos núcleos não esgotados; além disso, as peças brutas representam a maior quantidade de vestígios $(\mathbf{8 6 , 2 7 \% )}$, ou seja, provavelmente a maior parte das lascas produzidas provavelmente não eram utilizadas, o que sugere abundância de matéria prima, mesmo que não seja da melhor qualidade, e a possível falta de preocupação em relação ao aproveitamento total dos produtos de debitagem. Essas características compõem uma indústria lítica do tipo 
expediente (BINFORD,1979), ou seja, provavelmente as peças eram produzidas conforme as necessidades dos habitantes do sítio Limeira. Porém é importante lembrar que o grau de dureza do quartzo permitiu que apenas marcas muito evidentes de uso fossem identificadas.

Dessa forma, pode-se concluir que o artesão elaborava mentalmente a peça que necessitava elaborar e por meio de gestos técnicos a modelava a partir da matéria prima previamente escolhida para esse fim. O quartzo obtido principalmente através de seixos rolados, mas também de blocos, não era a matéria prima ideal, mas provavelmente era a de que o artesão dispunha, e a obtinha com certa facilidade, devido à proximidade de suas possíveis fontes em costões rochosos e no leito do rio Jabuti.

Assim, a organização tecnológica dos habitantes do sitio Limeira deveria estar diretamente vinculada à disponibilidade de matéria prima aptas ao lascamento (ANDREFSKY, 1994, p. 33).

Apesar de toda a dificuldade enfrentada para a transformação dos núcleos de quartzo em lascas utilizáveis devido à alta dureza, baixa tenacidade e/ou má formação da rede cristalina (no caso dos blocos), o artesão reunia os processos cognitivos à tradição social, tradição técnica, conhecimentos sobre lascamento e conhecimentos técnicos.

Ele utilizava-se do doxa ${ }^{31}$ para se apropriar dos elementos naturais e realizar seu trabalho sobre a pedra, deixando nela, - em associação à paisagem a sua volta impressas as suas características, o seu modus operandi, o seu modus vivendi, o seu habitus. O habitus, que é transmitido de uma geração a outra; que é inconsciente e incapaz de ser reduzido a um conjunto de regras, mas que existe e produz modelos regulares de comportamento, sem a imposição de normas e regras rígidas e se manifesta através da cultura material; dos núcleos, dos percutores, das lascas (BORDIEU, 1977).

As lascas. Essas são as peças que representam a maior parte da indústria lítica do sítio Limeira. Eram provavelmente elas, no geral, que povoavam a mente do artesão ao apropriar-se da matéria prima para iniciar sua transformação. A transformação que, através de golpes diretos e perpendiculares sobre o plano de

\footnotetext{
${ }^{31}$ Capítulo 1, item 1.4.
} 
percussão do núcleo, utilizando um percutor duro que praticamente desaparecia em sua mão, resultava nas lascas que seriam utilizadas de maneira expediente para cortar, raspar, perfurar.

Suas lascas não eram sofisticadas ou refinadas; muito menos refletem hoje, necessariamente, a estagnação cultural de seu povo. Trabalhar aquele tipo de matéria prima não era fácil. Provavelmente exigia habilidades para adaptação e inventividade humanas que lhe davam a capacidade de produzir ferramentas a partir das rochas menos apropriadas (MARTIN, 2008). Suas lascas eram simples; mas preenchiam suas necessidades de caçador-coletor-pescador garantindo a sobrevivência para si e para o seu povo.

\subsubsection{Distribuição espacial do material lítico:}

Para se obter compreensão holística a respeito de uma indústria lítica, é necessário não apenas realizar análises tecnotipológicas como também saber o contexto no qual as peças estavam inseridas, ou seja, é preciso também observar a distribuição espacial dos vestígios líticos ao longo da área estudada.

No caso do sítio Limeira, a maior concentração de material lítico encontrado está situada no Setor 1, com 308 peças líticas, seguido do Setor 2, com 229 e da tricheira $\mathrm{T}_{1}$, com 81 peças, conforme o quadro 4.13 e o gráfico 4.1 já apresentados.

Associando os dados estatísticos obtidos aos resultados quantitativos apresentados nos quadros 1 a 9, e ao mapa contido na Fig. 3.7 - Pranchas 1 e 4, pode-se observar que:

- No Setor 1 foram localizados os percutores de granito (1) e basalto (3), além de percutor de quartzo (5);

- No Setor 2 foi coletado 1 percutor de quartzo;

- A trincheira $T_{1}$ apresentou 6 percutores de quartzo;

- Na trincheira T2 não foram localizados percutores;

- Dezesseis lascas iniciais $(76,2 \%)$ foram encontradas na trincheira $T_{1}$ entre 7 e 8 metros desde a base ${ }^{32}$ e $38 \mathrm{~cm}$ de profundidade, onde também foram encontrados 9

\footnotetext{
${ }^{32}$ Ponto de interseção entre as trincheiras $T_{1}$ e $T_{2}$.
} 
núcleos corticais (36\%) e 50 estilhas, o que representa $74,62 \%$ dos refugos de lascamento;

- Na trincheira $\mathrm{T}_{2}$ (a 4 metros desde a base e 30 a $40 \mathrm{~cm}$ de profundidade) foram coletadas 5 lascas iniciais (33,7\%), 4 núcleos corticais (16\%) e nenhuma estilha;

- No Setor 1 foram coletados 7 núcleos corticais (28\%) e 10 estilhas (14,92\%). Não foram coletadas lascas iniciais;

- O Setor 2 apresentou 5 núcleos corticais (20\%) e 7 estilhas (10,46\%). Não foram encontradas lascas iniciais.

De acordo com Prous (1986/1990), a presença e a área do córtex nas lascas são elementos diretamente ligados ao estágio da debitagem. Segundo o autor, a primeira etapa desse processo apresenta lascas com faces externas (e eventualmente os talões) parcial ou totalmente corticais. Dessa forma, a existência de lascas iniciais, lascas com talão cortical, núcleo com alta porcentagem de córtex e resíduos de lascamento (estilhas e refugos de lascamento), podem indicar que o processo de debitagem iniciou-se em determinado local. Os resultados apresentados sugerem que tal atividade possivelmente ocorreu na trincheira $T_{1}$.

Em relação aos tipos de lascas, é importante notar que combinando os dados dos quadros 1 a 9 , tem-se:

- A maioria dos raspadores foram encontrados no Setor $1(50,36 \%)$, seguido do Setor $2(33,10 \%)$;

- A maioria dos furadores foram coletados no Setor 1 e na trincheira $T_{2}$, com 10 peças em cada local $(35,71 \%)$.

Assim, verificando essa distribuição espacial com o auxílio da Fig. 3.7 - Pranchas 1 e 4, pode-se observar que a maioria dos raspadores e furadores está concentrada em uma região do sítio Limeira.

Conforme já citado no capítulo 2, não foram encontrados vestígios líticos associados à fogueira. 


\subsection{ANÁLISE DO MATERIAL MALACOLÓGICO:}

No decorrer de todas as 4 campanhas de pesquisa intensiva de campo, todo o material arqueofaunístico coletado foi de origem malacológica, não sendo possível então a identificação dos outros grupos alimentares dos habitantes do sítio Limeira. Assim, a análise do material malacológico é de suma importância para a compreensão do padrão de subsistência daquelas pessoas.

\subsubsection{Campanhas de pesquisa intensiva de campo:}

Durante as pesquisas realizadas em campo, foi observado que todas as conchas estavam dispostas em bolsões, que foram identificados nos setores 1 e 2 e na trincheira $T_{1}$. Os resultados obtidos durante essa etapa da pesquisa estão dispostos a seguir:

- Campanha de resgate arqueológico - 2009:

Durante a campanha de resgate arqueológico realizada por Perota (2010) foram localizados dos bolsões malacológicos distribuídos entre os setores 1 e 2 . A quantificação de conchas encontradas em cada setor está disposta no quadro abaixo:

Quadro 4.30: Dados quantitativos do material malacológico. Resgate arqueológico.

\begin{tabular}{|c|c|c|}
\hline Profundidade & Setor 1 & Setor 2 \\
\hline $0-10$ & 0 & 10 \\
\hline $10-20$ & 35 & 84 \\
\hline $20-30$ & 39 & 14 \\
\hline $30-40$ & 26 & 6 \\
\hline $40-50$ & 20 & 164 \\
\hline
\end{tabular}

Perota (2010). 
- $1^{a}$ Campanha de campo - pesquisa acadêmica - setembro de 2012:

Durante a $1^{\text {a }}$ campanha foi encontrado pouquíssimo material malacológico, e mesmo com todo o cuidado, o mesmo acabou desfazendo-se durante o processo de decapagem do solo. Isso se deveu talvez pelo fato de ter havido período muito intenso de chuvas pouco tempo antes da pesquisa de campo, o que de certa forma perdurou com a presença de precipitações intensas, porém intermitentes durante a época das escavações. Dessa forma, a alta umidade do solo pode ter fragilizado o material, ocasionando em seu esfarelamento.

- $2^{a}$ Campanha de campo - pesquisa acadêmica - dezembro de 2012:

$\mathrm{Na} 2^{\mathrm{a}}$ campanha o material malacológico pôde ser evidenciado na trincheira $T_{1}$. As conchas puderam ser observadas a partir da profundidade de $20 \mathrm{~cm}$, aumentando em concentração gradativamente até não haver mais evidências após os $40 \mathrm{~cm}$ de profundidade. No perfil estratigráfico o material malacológico também foi evidenciado. Não houveram ocorrências de conchas na trincheira $T_{2}$. Esses dados estão dispostos nos quadros a seguir:

Quadro 4.31: Material malacológico, $2^{\text {a }}$ campanha, Perfil.

\begin{tabular}{|c|c|}
\hline Localização & Perfil \\
\hline № de peças & 60 \\
\hline
\end{tabular}

Quadro 4.32:Material malacológico, 2ª campanha, $T_{1}$.

\begin{tabular}{|c|c|c|}
\hline $\begin{array}{rr}\text { Localização } & \text { vert. } \\
& \text { hor. }\end{array}$ & $\begin{array}{l}20 \mathrm{~cm} \\
2-3 \mathrm{~m}\end{array}$ & $\begin{array}{c}30-40 \mathrm{~cm} \\
1-3 \mathrm{~m}\end{array}$ \\
\hline № de peças & 40 & 635 \\
\hline
\end{tabular}

- $3^{a}$ Campanha de campo - pesquisa acadêmica - maio de 2013:

Durante essa etapa de campo não foram observados bolsões malacológicos no sítio Limeira, mas foram identificadas concentrações de conchas nos costões rochosos já citados, localizados nas imediações do assentamento. Foi então realizada a coleta desse material malacológico vivo para posterior identificação. 


\subsubsection{Características do material malacológico:}

Para a realização de análise, todo o material coletado durante as campanhas de pesquisa intensiva de campo foi levado ao laboratório, higienizado a seco com escova de dente de cerdas macias e contabilizado. Além disso, foi realizada a sua identificação taxonômica. Como resultado, sabe-se que todo o material arqueofaunístico é pertencente a espécies do filo Mollusca das classes bivalvia e gastropoda, conforme exposto a seguir:

- Bivalves - Arca imbricata, Crassostrea rhizophorae, Lucina pectinata, Lunarca ovalis, Iphigenia brasiliana e Anomalocardia brasiliana.

- Gastrópodes - Cymatium parthenopeum e Stramonita haemastoma.

As foto 4.1 e 4.2 representam parte do material malacológico coletado no sítio Limeira:

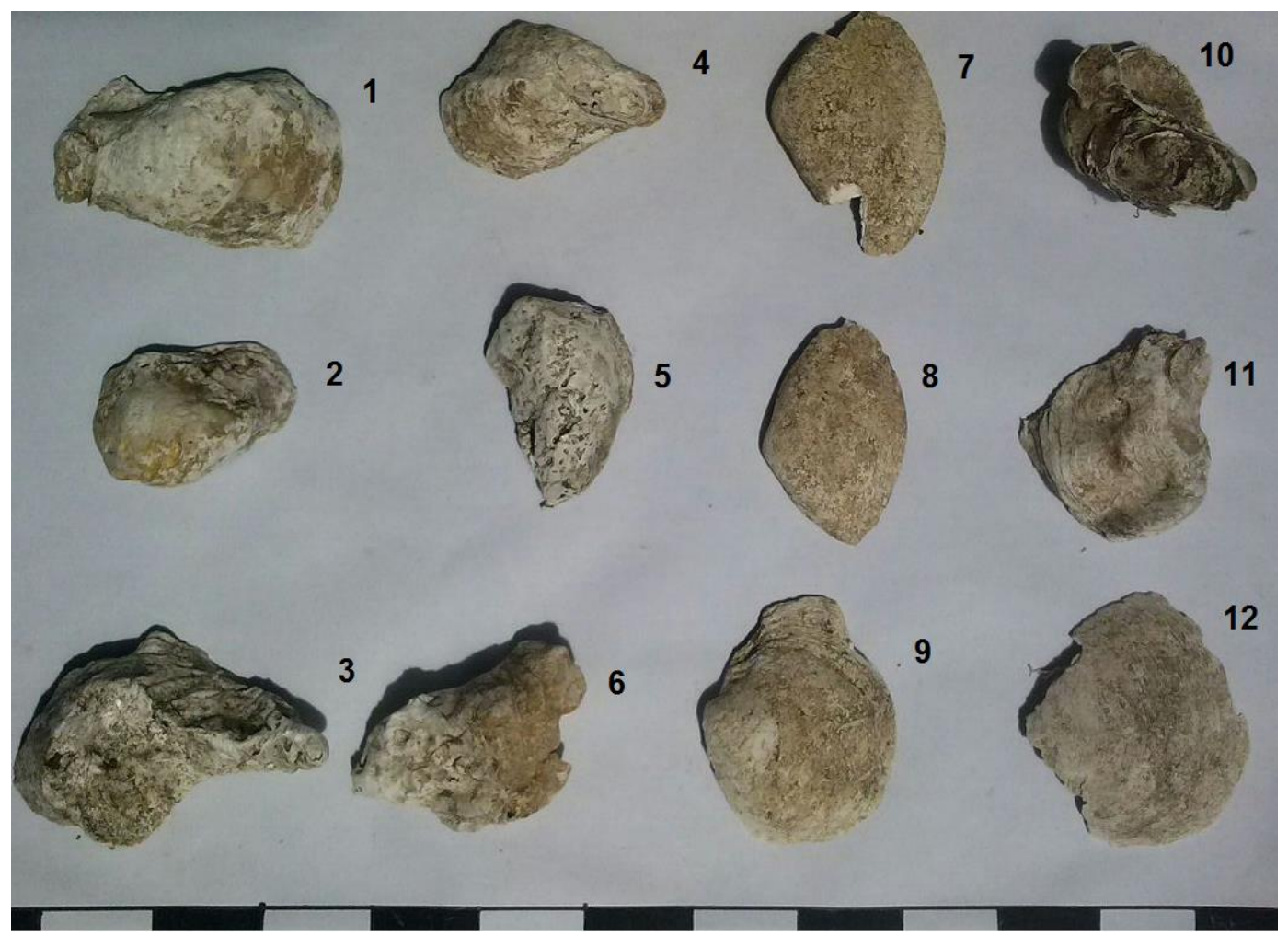

Foto 4.1: 1,2,3, 4, 6, 10 e 11 - Crassostrea rhizophorae (Class. Guilding, 1828); 5 - Arca imbricata (Class. Bruguière,1789) 7 e 8 - Iphigenia brasiliana (Class. Lamarck, 1818); 9 e 12 Lucina pectinata (Class. Gmelin, 1791). Foto: Maria de Lourdes Franklin ago/2014. Fonte: Rios (1985). 


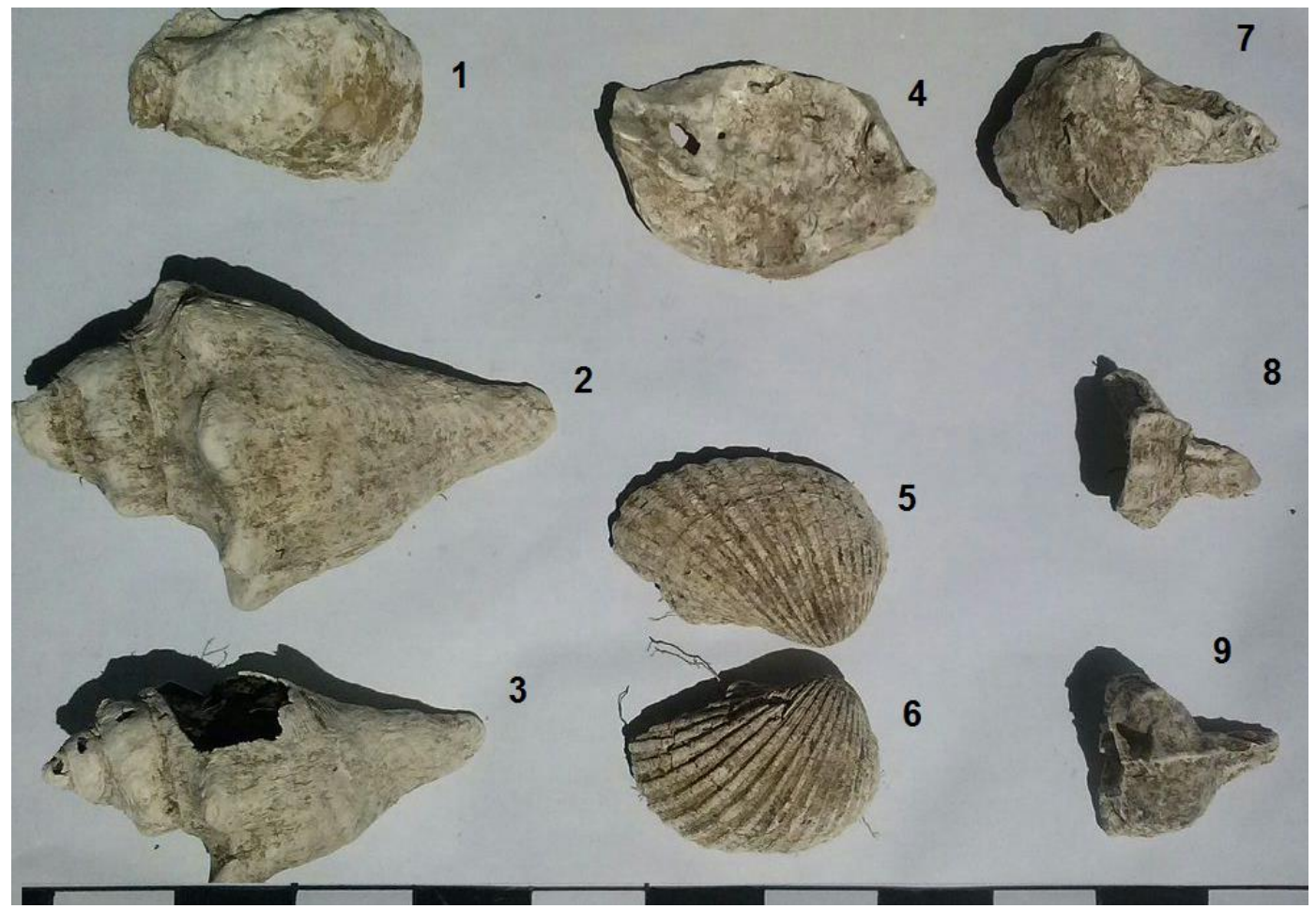

Foto 4.2: 2 e 3 - Stramonita haemastoma (Class. Linnaeus, 1797), 5 e 6 - Lunarca ovalis (Class. Bruguière, 1789) e Crassostrea rhizophorae (Class. Guilding, 1828). Foto: Maria de Lourdes Franklin ago/2014. Fonte: Rios (1985).

Comparando-se com os resultados obtidos através do material vivo coletado nos costões rochosos e ao longo do manguezal, pôde-se observar que:

- todas as espécies encontradas nos bolsões malacológicos também foram identificadas nos costões rochosos (Foto 2.1); as Crassostrea rhizophora, também apresentaram ocorrências nas extensões de caule das árvores de mangue Rhizophora mangle. Isso sugere que estes locais eram as prováveis fontes desse tipo de alimento;

- não foram constatadas conchas com marcas peculiares de uso cotidiano ou para enfeites, como furos. Esse dado pode indicar que esses espécimes eram utilizados para a subsistência do grupo.

Quanto à distribuição espacial do material malacológico no sítio Limeira, observando os resultados apresentados nos quadros 4.30 e 4.31 em conjunto com 
os dados apresentados no Capítulo $3^{33}$ e a Fig. 3.7 - Pranchas 3 e 4, pode-se observar que:

- as conchas estão distribuídas em 3 bolsões;

- a maior quantidade de conchas está localizada na extremidade da trincheira $T_{1}$, entre 20 e $40 \mathrm{~cm}$ de profundidade;

- a trincheira $T_{2}$ não apresentou conchas, porém, está localizada paralelamente ao Setor 2, onde há concentração destes vestígios;

- o $3^{\circ}$ bolsão malacológico do sítio Limeira se encontra no Setor 1.

${ }^{33}$ Seção 3.5.1. 


\section{CONSIDERAÇÕES FINAIS}

A análise do contexto arqueológico do sítio Limeira possibilitou a investigação de vestígios de uma população caçadora-coletora-pescadora que viveu há cerca de 670 anos AP $\left({ }^{14} \mathrm{C}\right.$ - CENA/USP) em assentamento a céu aberto, ocupando um ambiente de transição entre estuário (manguezal) e restinga, localizado onde atualmente é o Município de Guarapari, no Estado do Espírito Santo.

O registro arqueológico do sítio Limeira é representado pela cultura material lítica (lascada) e malacológica (agrupada na forma de bolsões), além de estrutura de combustão (fogueira); todos dispostos em apenas um estrato arqueológico.

Essas evidências fazem parte de um sistema social, que em conjunto com o contexto ambiental na qual estavam inseridas, podem refletir o modo de vida desses habitantes pretéritos, estruturado por meio de escolhas culturais veiculadas pela transmissão e aprendizagem de conhecimentos técnicos de forma consciente ou inconsciente; pelo seu habitus.

A pesquisa apresentada nesta Dissertação é pautada em dados coletados através de consultas a referências especializadas, pesquisas intensivas de campo e análises laboratoriais. Os vestígios arqueológicos analisados foram obtidos através de resgate arqueológico realizado pelo Prof. Ms. Celso Perota em 2009 e de 3 (três) campanhas de pesquisas intensivas de campo desenvolvidas especificamente para esta Dissertação durante os anos de 2012 e 2013.

A abordagem teórica e metodológica utilizada para a evidenciação da cultura material através da realização de pesquisas de campo, foram baseadas nos métodos de escavação por superfícies amplas com técnica de decapagens por camadas naturais desenvolvidas por Leroi-Gourhan $(1950 ; 1964)$ centradas no conceito Totalidade Social de Mauss (1974b) e adaptadas às características do solo brasileiro pela Prof $^{a}$ Dr $^{\text {a }}$ Luciana Pallestrini (PALLESTRINI \& PERASSO, 1984; ALVES, 2009).

Esta abordagem tem como fundamentação o princípio da tridimensionalidade, com foco, sobretudo, na horizontalidade, como meio de expor a disposição espacial dos vestígios e a ocorrência de estruturas, evidenciando os solos arqueológicos como se fossem "cenas congeladas do passado" (ALVES, 2002). A verticalidade revela a estratigrafia, que, por sua vez, associada a datações absolutas permite 0 
reconhecimento de diferentes horizontes arqueológicos e a ocorrência ou não de continuidade na ocupação.

Através dessa técnica pôde-se observar que o sítio Limeira é unicomponencial, ou seja, apresenta apenas um horizonte ocupacional, onde foram evidenciados vestígios líticos e de conchas. Nesse sentido, foram identificadas 2 (duas) estruturas básicas, que se apresentaram na forma de 3 (três) bolsões malacológicos e uma fogueira.

Os bolsões malacológicos apresentaram conchas da classe Gastropoda representada pelas espécies Cymatium parthenopeum e Stramonita haemastoma e Bivalvia - apresentando as espécies Arca imbricata, Crassostrea rhizophorae, Lucina pectinata, Lunarca ovalis, Iphigenia brasiliana e Anomalocardia brasiliana.

Todas essas espécies foram posteriormente identificadas em costões rochosos localizados a menos de $1 \mathrm{~km}$ do sítio Limeira. No caso dos vestígios pertencentes à espécie Crassostrea rhizophora, houve ocorrências também nas extensões de caule das árvores de mangue Rhizophora mangle.

Em relação à fogueira, o processo de decapagem revelou que esta possui 21 fragmentos de rocha granítica dispostas de forma semi-circular, com $83 \mathrm{~cm}$ de diâmetro na direção N-S e $68 \mathrm{~cm}$ de diâmetro na direção L-O, e em superfície escavada, com $32 \mathrm{~cm}$ de profundidade, sendo então uma fogueira en cuvette, ou na forma de bacia (LEROI-GOURHAN,1976; PERLÈS, 1976; YAR \& DUBOIS, 1996; VILLAGRAN, 2012). Não foram evidenciados instrumentos líticos nem restos faunísticos em região imediatamente próxima à fogueira.

Além do método de escavação por superfícies amplas e técnica de decapagem por camadas naturais, também foram empregados os procedimentos de investigação em arqueologia da paisagem propostos por Morais (2012), nos quais a pesquisa em campo é dividida em 3 (três) estágios com atividades distintas entre si e foco em diferentes escalas, o que inclui mapeamento e reconhecimento de área, além de análise de compartimentos paisagísticos e estruturas com potencial arqueológico, para posterior realização do processo de escavação do sítio.

O estudo dos vestígios arqueológicos teve como princípios básicos os conceitos: cadeia operatória, através dos títulos de Leroi-Gourhan (1964), Balfet (1991) e Lemonnier (1980;1992); antropologia das técnicas de Mauss (1974b e habitus de Bordieu (1977; 1994b). Esses conceitos permitem que se tenha maior compreensão a respeito das escolhas técnicas adotadas pelas populações pré-históricas. 
Associando os resultados das análises efetuadas sob essa perspectiva às características de espacialidade no assentamento e contexto ambiental, é possível realizar interpretações sobre o processo da manufatura de certos elementos da indústria lítica, como procura, obtenção e transporte da matéria-prima, até os prováveis motivos para descarte e posterior formação do registro arqueológico.

Os procedimentos adotados para realização das análises dos vestígios líticos em laboratório, bem como as nomenclaturas utilizadas durante o desenvolvimento desta pesquisa seguiram os padrões convencionados e propostos por Brézillon (1968), Tixier (1980) Emperaire (1967), Pallestrini e Chiara (1978) e Morais (1987; 2007).

A partir da análise dos dados obtidos através dessas abordagens, foi possível verificar que a organização tecnológica no sítio Limeira esteve concentrada principalmente nos processos de procura, obtenção, transporte, seleção e processamento de seixos de quartzo (em sua maioria), afim de que fossem utilizados como meio de manufatura de ferramentas necessárias para 0 desenvolvimento de atividades do cotidiano social.

As prováveis fontes de obtenção de matéria prima são o leito do rio Jabuti, localizado a cerca de $2 \mathrm{~km}$ do sítio Limeira e costões rochosos dispostos a menos de $1 \mathrm{~km}$ desse local. A proximidade dessas áreas e características como: núcleos leves e de pequenas dimensões, presença de núcleos corticais e de quantidades consideráveis de lascas corticais e iniciais, além de estilhas na trincheira $T_{1}$, sugere que a matéria-prima era transportada pelos habitantes do sítio Limeira desde a área fonte até esse local no assentamento. Posteriormente, a matéria-prima deveria ser submetida à sequência de redução através de debitagem para a obtenção das lascas utilizadas em as atividades cotidianas do grupo.

De acordo com o observado no estudo dos vestígios líticos, durante o processo de debitagem eram utilizados percutores duros de quartzo (maioria), além de basalto e granito, que apresentaram pequenas dimensões, baixo peso e traços de utilização apenas em sua extremidade, o que expõe características de lascamento unipolar por percussão direta.

Associando os aspectos descritos à identificação de uma quantidade representativa de núcleos globulares, pode-se obter como resultado lascas pequenas e irregulares, o que foi observado no sítio Limeira.

Além disso, o grande número de lascas nesta indústria lítica sugere que o principal objetivo do artesão era a sua obtenção. Em adição, a padronização dos 
tipos de talão, ângulo de chasse e largura observados nas mesmas, demonstram a possibilidade de que havia uma ação proposital por parte do artesão para a obter lascas com características diferentes adequadas ao atendimento de suas necessidades.

Essas ferramentas apresentaram-se em simplicidade, sem utilização de retoque como técnica de manufatura. Porém, as próprias características de clivagem do quartzo, que proporciona extremidades agudas, e a presença natural de bordos cortantes nas lascas obtidas a partir desse mineral, permitiam seu uso para a realização de ações como cortar, perfurar, raspar, etc.

Também foi observada a presença de uma quantidade representativa de núcleos não esgotados e aparente baixo desgaste das lascas, o que aponta uma possível abundância de matéria-prima. Esses aspectos sugerem que a indústria lítica do sítio Limeira era do tipo expediente (Binford, 1979), ou seja, as peças provavelmente eram produzidas conforme a necessidade.

Todos os fatores descritos acima revelam muito a respeito do modo de vida da população que habitou o sítio Limeira; porém, sabe-se que o registro arqueológico não existe de maneira isolada, mas está diretamente relacionado ao seu contexto espacial em todas as escalas e âmbitos das atividades humanas (CRIADO-BOADO, 1995). Assim, partindo do princípio de que paisagens são o meio pelo qual as pessoas sobrevivem e se sustentam, e que cada componente envolve a essência da totalidade das relações humanas e naturais (INGOLD, 1993), que são as paisagens humanas (ZEDEÑO, 1997), foi realizada a construção do universo empírico do sítio Limeira, estruturado com base na aplicação do conceito de paisagem. As principais referências utilizadas com seus respectivos autores foram: Santos (1978; 1997; 2005; 2008), Criado-Boado (1995; 1997; 1999) e Morais (2011; 2012).

Neste sentido, foram reunidas informações geológicas, geomorfológicas, pedológicas, hidrográficas, hidrológicas, biológicas, oceanográficas e climáticas, além de dados paleoambientais.

Dessa forma, buscou-se realizar a interpretação da paisagem natural através de uma breve caracterização ambiental do sítio Limeira à sua época de ocupação, com a reunião de dados paleoambientais sobre o período Quaternário, mais precisamente do Holoceno no litoral brasileiro, com fulcro no Estado do Espírito Santo e regiões próximas ao sítio Limeira. Os autores e títulos utilizados como base 
foram: Suguio (2003; 2005; 2010), Fairchild et al. (2009), Pessenda et al. (2012), Buso Jr. (2014) e Martin et al. (1997).

Correlações entre os resultados a respeito das variações das características paleoambientais ao longo do Holoceno e da época de ocupação do sítio Limeira indicaram que a cerca de 670 anos $A P,{ }^{34}$ o manguezal e a restinga já constituíam o seu ambiente de inserção, e que o clima predominante era o tropical chuvoso, com elevadas médias de temperatura e umidade. Dessa forma, a vegetação que circundava o sítio Limeira era composta pelas árvores típicas de ambiente de manguezal e, provavelmente, por arbustos e árvores de pequeno porte, característicos do ambiente de restinga.

Apesar de o registro arqueológico evidenciado ter se apresentado na forma de líticos e conchas, a riqueza faunística característica dos manguezais e a proximidade da hoje denominada Baía de Guarapari com seus costões rochosos, pode ter possibilitado a subsistência dessa população baseada na coleta de moluscos, mas também de crustáceos, além de caça e pesca. Além disso, esse tipo de ambiente pode ser considerado potencial fonte para obtenção de lenha para a construção de fogueira.

Devido ao fato de estar inserido em área protegida por manguezal que margeia uma baía, o sítio Limeira não recebia impacto direto de ondas, porém, mesmo situando-se em região de micromaré, cuja amplitude não excede os $2 \mathrm{~m}$, seus vestígios arqueológicos podem estar sujeitos à ação das águas da maré, já que sua topografia é bastante suave, com ponto mais elevado aos $2 \mathrm{~m}$ de altitude. Esse fator pode ter comprometido os vestígios biológicos do sítio, sendo a possível causa da não observação de nenhum resquício alimentar, exceto conchas por serem compostas de calcário $\left(\mathrm{CaCO}_{3}\right)$.

Conforme observado, através da interação entre a paisagem natural e sua percepção e cognição, as populações provavelmente utilizavam o seu espaço geográfico, modificando a matéria e obtendo meios de subsistência, construindo assim o seu espaço social, que deveria ser determinado por meio de seletividade histórica e geográfica, decorrente de necessidades e/ou escolhas sociais (SANTOS, 1978; 1997; PROUS, 1986/1990; FAGUNDES, 2004; MORAIS, 2007).

${ }^{34}$ Datação conferida ao sítio Limeira, conforme Capítulo 3, item 3.6. 
O espaço social se manifesta no sítio Limeira através do próprio local de assentamento; o provável lugar de vida e trabalho, posto à luz do conhecimento por meio das já expostas evidenciação e análise da cultura material, considerando a sua espacialidade, na forma das estruturas arqueológicas - fogueira e bolsões malacológicos -, que constituem o ambiente construído, e os vestígios líticos e conchas (SANTOS, 1978; ZEDEÑO, 1997).

O aprofundamento desses estudos poderia revelar dados ainda mais contundentes. Análises com base nos isótopos estáveis de carbono contidos no solo poderiam identificar se, nesse local haviam espécies que dependiam de maior ou menor taxa de umidade para a sua sobrevivência, o que poderia confirmar as informações climáticas e até mesmo sobre a vegetação pretérita do local, obtidas através de bibliografias (PESSENDA et al., 1998; 2012). Porém, a área onde se localiza o sítio é utilizada pela população de entorno para pastagem de animais domésticos, como cavalos e cabras.

Nesse sentido, é importante observar que um solo com baixo teor de argila (como é o caso do solo do sítio Limeira) possui baixa compactação, ou seja, suas camadas podem sofrer perturbações com facilidade, já que por seus grãos serem mais grossos oferecem mais espaço entre um e outro. Dessa forma, não somente raízes de plantas podem se desenvolver facilmente, conforme foi possível notar durante 0 processo de decapagem, mas a água e outras substâncias líquidas podem percorrer livremente entre as camadas do solo, tanto conforme a gravidade, como a água da chuva, como em sentido contrário, no caso da água proveniente da elevação da maré.

Assim, a prática de depositar os animais no local onde se insere o sítio Limeira pode ter ocasionado a contaminação do solo arqueológico, através da urina e dejetos desses animais, tornando os resultados de análise de isótopos estáveis de carbono possivelmente questionáveis.

Análises antracológicas poderiam complementar as informações supracitadas a respeito das características da vegetação do sítio Limeira à época de sua ocupação, através da utilização dos carvões coletados ao longo do estrato arqueológico escavados por camadas naturais e os fragmentos localizados na fogueira. Esse estudo permitiria revelar, até mesmo em nível de espécie, quais eram as plantas que compunham esses carvões, ou seja, quais espécies faziam parte da vegetação circundante do sítio Limeira (SCHEEL-YBERT et al., 2003; KIPNIS, L. M.; SCHEEL- 
YBERT, 2005). Entretanto, limitações impostas, como tempo e recursos reduzidos para a pesquisa, impediram que essas análises fossem realizadas nesta Dissertação. Esses procedimentos podem ser retomados em pesquisas futuras.

Exceto por suas limitações, convém destacar que esta pesquisa, através da produção de conhecimento realizada de maneira sistemática, contribuiu para o estabelecimento de um contexto arqueológico do litoral capixaba, ainda pouco estudado academicamente, e que ainda necessita ter suas particularidades desvendadas por estudos regionais posteriores. 
REFERÊNCIAS:

AB'SABER, A. N. Os domínios da natureza no Brasil - potencialidades paisagísticas. São Paulo: Atelier Editorial, 2003.

Brasil: paisagens de exceção - o litoral e o Pantanal MatoGrossense: patrimônios básicos. São Paulo: Ateliê Editorial, 2006.

ALBINO, J. Processos de sedimentação atual e morfodinâmica das praias de Bicanga a Povoação, ES. Tese de Doutorado. Programa de Pós-graduação em Geologia Sedimentar. Instituto de Geociências da Universidade de São Paulo. São Paulo, 1999.

ALBINO, J. et al. Geomorfologia, Tipologia, Vulnerabilidade Erosiva e Ocupação Urbana das Praias do Litoral do Espírito Santo, Brasil. Geografares. Ed. da UFES, publicações $\mathrm{CCHN}, \mathrm{n}^{\circ 2}$ 2, Vitória, 2001.

ALBINO, J., VALE, C. C., GOMES, R. C. Descrição climática do litoral do Espírito Santo. Vitória: Instituto do Milênio - RECOS. Modelagem, monitoramneto, erosão e ocupação costeira - MMOC/ES, 2005.

ALVES, D. M. A indústria lítica do sambaqui Mar Casado, litoral do Estado de São Paulo. Dissertação de Mestrado. Museu de Arqueologia e Etnologia da Universidade de São Paulo, São Paulo, 2011.

ALVES, M. A. Teorias, métodos, técnicas e avanços na Arqueologia Brasileira. Revista Canindé, n. 02. Xingó, dez. 2002.

Assentamentos e cultura material indígenas anteriores ao contato no Sertão da Farinha Podre, MG e Monte Alto, SP. Tese de Livre Docência. São Paulo, MAE-USP, 2009.

AMADOR, E. S. O Barreiras Pleistocênico no Estado do Espírito Santo e seu Relacionamento com Depósitos de Minerais Pesados. Anais XXXII Congresso Brasileiro de Geografia, vol 4, Salvador, 1982.

ANSCHUETZ, K. F., WILSHUSEN, R. H., SCHEICK, L. An archaeology of landscapes: perspectives and directions. Journal of Archaeology Research. v.08, n. 02, 2001.

ARAI, M. A grande elevação eustática do Mioceno e sua influência na origem do Grupo Barreiras. Geologia USP (Série Científica), São Paulo, n.06, pp. 01-06, 2006. 
AZEVEDO, L. G. Tipos de vegetação do estado do Espírito Santo. Revista Brasileira de Geografia n. 24, p. 111-115, 1962.

BACKHEUSER, E. A. Os sambaquis do Distrito Federal. Boletim Geográfico, n.32, p.1052-1068, 1945.

BALFET, H. Des chaînes opératoires, pour qui faire? In: BALFET, H. Observer L'action technique - Des chaînes opératoires, por qquoi faire? Paris, CNRS, pp. 11-19, 1991.

BANDEIRA, A. M. Ocupações humanas pré-históricas no litoral maranhense: um estudo arqueológico sobre o sambaqui do Bacanga na ilha de São Luís Maranhão. Dissertação de Mestrado. Museu de Arqueologia e Etnologia da Universidade de São Paulo. São Paulo, 2008.

BELtRÃO, M. C. M. C. Pré-história do Rio de Janeiro. Tese de Doutorado. Universidade Federal do Rio de Janeiro, 1969.

Documentos sobre a pré-história dos Estados do Rio de Janeiro e Guanabara (1500-1963). Coleção Museu Paulista, Série de Arqueologia, n.02, p. 13-79, 1976.

BELTRÃO, M. C. M. C., KNEIP, L. M. Arqueologia e geormorfologia. Tentativa de uma abordagem interdisciplinar. Boletim Carioca de Geografia, ano XVIII, p.4-20. Rio de Janeiro, 1967.

BEZERRA DE MENEZES, U. T. Arqueologia de Salvamento no Brasil: uma avaliação crítica. Seminário sobre Salvamento Arqueológico. Rio de Janeiro: SPHAN, 1988.

BIGARELLA, J. J.; The Barreiras Group in Northeastern Brazil. In: Academia Brasileira de Ciências, São Paulo, v. 47, p. 365-393, 1975. Suplemento.

BINFORD, L. Organization and formation processes: looking at curated technologies. Journal of Anthropological Research n.35, p. 255-273. 1979.

. The archaeology of place. Journal of Anthropological Archaeology n.1, p.5-31. 1982.

BOAS, F. Alguns problemas de metodologia nas ciências sociais. In: BOAS, F. Antropologia cultural. p. 53-66. Rio de Janeiro: Jorge Zahar Editor, 2004a.

A formação da antropologia americana 1883-1911: antologia. STOCKING JR., G. W. (org.). Rio de Janeiro : Contraponto, UFRJ, 2004b. BORDES, F. Étude comparative des différentes techniques de taille du silex et des roches dures. L'Antropologie, n. 51, p. 1.29, 1947. 
BOURDIEU, P. Outline of a theory of practice. Cambridge: Cambridge University Press, 1977.

O poder simbólico. Cap.2. Esboço de uma teoria da prática. Coleção Grandes Cientistas Sociais. Ática: São Paulo, 1994a.

O poder simbólico. Cap.1. Sobre o poder simbólico. Coleção Grandes Cientistas Sociais. Ática: São Paulo, 1994b.

BRASIL. Lei no 3924/61 de 26 de julho de 1961. Dispõe sobre os monumentos arqueológicos e pré-históricos. Diário Oficial da União, 28 de julho de 1961. Disponível em: http://www.planalto.gov.br/ccivil_03/leis/1950-1969/L3924.htm. Acesso em: dez. 2012.

BRASIL. Conselho Nacional do Meio Ambiente (CONAMA). Resolução no 001 de 23 de janeiro de 1986. Dispõe das definições, responsabilidades, critérios básicos e diretrizes gerais para uso e implementação da Avaliação de Impacto Ambiental como instrumentos da Política Nacional do Meio Ambiente. Diário Oficial da União, 17 de fevereiro de 1986. Disponível em: http://www.mma.gov.br/port/conama/res/ res86/res0186.html. Acesso em: jan 2013.

BRASIL. Conselho Nacional do Meio Ambiente (CONAMA). Resolução oㅡ 006 de 16 de setembro de 1987. Dispõe de regras gerais para o licenciamento ambiental de obras de grande porte. Diário Oficial da União, 22 de outubro de 1987. Disponível em: http://www.mma.gov.br/port/conama/res/res87/res0687. html. Acesso em: jan. 2013.

BRÉZILLON, M. Dicionário de Pré-história. Rio de Janeiro: Edições 70, 1969.

BUSO JR, A. A.; PESSENDA, L. C. R.; DE OLIVEIRA. P.E.; COHEN, M. C. L.; GIANNINI, P. C. F.; SCHIAVO, J. A.; ROSSETTI, D. F.; VOLKMER-RIBEIRO, C.; OLIVEIRA, S. M. B.; LORENTE, F. L.; BOROTTI FILHO, M. A.; BENDASSOLLI, J.; FRANCA, M. C.; GUIMARAES, J. T. F.; SIQUEIRA, G. S. Late Pleistocene and Holocene vegetation and climate dynamics and notes about Amazonian taxa at Atlantic Rainforest - Linhares, southeastern Brazil. Radiocarbon, v. 55, p. 17471762. 2014.

CALDARELLI, S. B. Lições da pedra: aspectos da ocupação pré-histórica no vale médio do rio Tietê. Tese de Doutorado apresentada à Faculdade de Filosofia, Letras e Ciências Humanas da USP, 1983.

FCA litorânea SUL - Patrimônio arqueológico: diagnóstico avaliação de impactos - programas. Scientia Consultoria Científica, 2008. 
CARDOSO DE OLIVEIRA, R. Mauss. Coleção grandes cientistas sociais. São Paulo: Ática, 1979.

CESAN. Companhia Espirito Santense de Saneamento. Disponível em: <http:// www.cesan.com.br. Acesso em: 15 jun 2013.

CETTO, P. H. Sonografia e faciologia da plataforma continental interna situada entre as Ilhas Escalvada e Rasa, Guarapari - ES. Monografia (Graduação em Oceanografia) apresentada ao departamento de Ecologia e Recursos Naturais da Universidade Federal do Espírito Santo, Vitória, 2005.

CRIADO-BOADO, F. Construción social del espacio y reconstrucción arqueológica del paisaje. Boletín de Antropología Americana, n.24,p.5-29. 1991.

.The visibility of the archaeological record and the interpretation of social reality. In: Ian Hodder et al. Interpreting Archaeology, Londres: Routledge, 1995.

Combining the different dimensions of cultural space: is a total archaeology os landscape possible? In: BOAD. F. C.; PARCERO, C. (Eds). TapaLandscape. Archaeology, heritage. Santiago de Compostela: Universidade de Santiago de Compostela. N. 2, 1997.

Del terreno al espacio: planteamientos y perspectivas para la arqueologia del paisage. Capa-criterios y convenciones em Arqueología del Paisage. Santiago de Compostela: Universidade de Santiago de Compostela, n. 6, 1999.

CRUZ, O. A llha de Santa Catarina e o Continente Próximo: Um Estudo de Geomorfologia Costeira. Florianópolis: Editora da UFSC, 1998.

CUNHA, E. S. História da odontologia no Brasil. Rio de Janeiro, 1952.

. Regressão dos terceiros molares no Homem do Sambaqui do Estado da Guanabara. Revista de Farmácia e Odontologia, ano XXVI, v.229-230, p. 2-10, 1960.

Sambaquis e outras jazidas arqueológicas: Paleontologia dentária e outros assuntos. Rio de Janeiro: Ed. Científica, 1963.

- Afecções alvéolo-dentárias da população do sambaqui do Pau Seco, Vitória, ES. In: Anais da Jornada Fluminense de odontologia Prof. Coelho e Souza, n. 05, p. 49-62. Nitérói, 1967.

- Sambaquis de Vitória. In: Resumos da Reunião Anual da

Sociedade Brasileira para o Progresso da Ciência, v.20, n.02, p. 455-56, 1968. 
Polidores neolíticos do Espírito Santo, Brasil. In: Resumos da Reunião Anual da Sociedade Brasileira para o Progresso da Ciência, v.22, p. 163, 1970.

DANA, J. D. Manual de mineralogía: tratado moderno para la ensenanza en Universidade y escuelas especiales y para guia de ingenieros de minas y geologos. 2. ed. Barcelona: Reverte, 1960.

DESNOYERS, J. Observations sur un ensemble de dépots marins plus récent que le terrain tertiaire du bassin de la Seine, et pouvant constituer une formation géologique distincte, precédée d'un aperçu sur la non-simultaneité des bassins tertiaires. Annales des Sciences Naturelles, v.16, p. 171-214 e 402-491, 1829.

DHN. Tábuas de marés. Disponível em: http://www.mar.mil.br/dhn/chm/tabuas/ index.htm. Acesso em: fev 2013.

DIAS JR., O. A fase Itaipu - sítios sobre dunas no Estado do Rio de Janeiro. Separata dos Anais do III Simpósio de Arqueologia da Área do Prata, Pesquisas. Instituto Anchietano de Pesquisas - Série Antropologia n.20, 1969.

A questão das origens, da continuidade e da mudança na préhistória. Clio. Série Arqueológica, n.08, p. 153-169, 1992a.

A fase Itaipu, RJ. In: MEGGERS, B., EVANS, C. Prehistoria sudamericana: nuevas perspectivas. Washington: Taraxacum, 1992b.

DIAS JR., O., CARVALHO, E. T. A fase Itaipu, RJ: novas considerações. Arquivos do Museu de História Natural. n.8-9, p.95-106, 1983/84.

DIAS JR., O., CARVALHO, E. T. A tradição Itaipu no Rio de Janeiro - Discussão dos tópicos: a questão da imobilidade cultural. In: BELTRÃO, M. C. M. C. (org.), Arqueologia do Rio de Janeiro, p.105-110. Niterói: Arquivo Público do Estado do Rio de Janeiro, 1995.

DOMingueZ, J. M. L., BitTencouRT, A. C. S. P., MARTIN, L. Controls on Quaternary coastal evolution of the east-northeastern coast of Brazil: roles of sealevel history, trade winds and climate. Sedimentary Geology. n. 80, p.213-232, 1992.

EMPERAIRE, A., L. Guia para estudo das indústrias líticas da América do Sul. Manuais de Arqueologia, n.02. Curitiba: Universidade do Paraná, 1967.

FAGUNDES, M. Sítio Rezende: das cadeias operatórias ao estilo tecnológico - um estudo da dinâmica cultural no médio vale do Paranaíba, Centralina, Minas Gerais. 
Dissertação de Mestrado apresentada ao Museu de Arqueologia e Etnologia da USP, 2004.

FAIRCHILD, T. R., TEIXEIRA, W., BABINSKI, M. Em busca do passado do planeta: tempo geológico. In: Teixeira, W., Toledo, M. C. M., Fairchild, T. R., Taioli, F. Decifrando a Terra. São Paulo: Companhia Editora Nacional, 2009.

FIGUTI L. Les sambaquis COSIPA (4200 à 1200 ans BP):étude de la subsistance chez les peuples préhistoriques de pêcheursramasseurs de bivalves de la côte centrale de l'état de São Paulo, Brésil. Thèse de Doctorat, Muséum National d'Histoire Naturelle. Paris, 1992.

FOX, C. The Personality of Britain. Cardiff: National Museum of Wales. 1932.

GARCIA, C. del R. Estudo comparativo das fontes de alimentação de duas populações pré-históricas do litoral paulista, São Paulo. Tese de Doutorado apresentada ao Departamento de Zoologia, Instituto de Biociências da Universidade de São Paulo, 1972.

GASPAR, M. D. Aspectos da organização social de um grupo de pescadores, coletores e caçadores: região compreendida entre a Ilha Grande e o delta do Paraíba do Sul, Estado do Rio de Janeiro. Tese de Doutorado. Faculdade de Filosofia, Letras e Ciências Humanas da Universidade de São Paulo, 1991.

Aspectos da organização social de pescadores-coletores: região compreendida entre a Ilha Grande e o Delta do Paraíba do Sul, Rio de Janeiro. Rio Grande do Sul: Instituto Anchietano de Pesquisas, 2003.

GASPAR, M. D., AFONSO, M. C., DE BLASIS, P., EGGERS, S., FIGUTI, L., FISH, P., FISH, S, KLÖKLER, D.M., LAHR, M. M., MORLEY, E. Uma breve história do projeto de pesquisa Padrão de assentamento e formação de sambaquis: Arqueologia e Preservação em Santa Catarina. Revista do CEPA, v. 23, n. 29: 108117. Santa Cruz do Sul, 1999.

FRANKLIN, M. E. Variação espaço-temporal da distribuição dos minerais pesados na praia da Areia Preta, Guarapari - ES. Monografia (Graduação em Oceanografia) apresentada ao departamento de Ecologia e Recursos Naturais da Universidade Federal do Espírito Santo, Vitória, 2006.

GLIESH, R. Sobre a Origem dos Sambaquis. Egatea, v.17, n.3, p.199-208. 1930.

GONZALEZ, M. M. B. Tubarões e raias na pré-história do litoral de São Paulo. Tese de Doutorado. Museu de Arqueologia e Etnologia da Universidade de São Paulo, São Paulo, 2005. 
GOOGLE EARTH. Disponível em: <http://www.earth.google.com>. Acesso em: 02 out. 2014.

GUIDON, N. Nota prévia sobre o sambaqui Mar Casado. Homenaje a Fernando Márquez-Miranda, p.176-204. Publicaciones del Seminário de Estudios Americanistas y del Semináriode Antropologia Americana, Universidades de Madrid y Sevilla, 1964.

GUIDON, N. PALLESTRINI, L. Estudo da indústria do sambaqui Mar Casado. Anhembi, 47-49, São Paulo, 1962.

HICKS, R. Ways of inhabiting the world: landscape archaeology. American Antropologist. New Series, v. 104, n.1, p. 315-320. mar 2002. Disponível em: http://www.jstor.org/stable/683794 Acesso em out. 2012.

HIRSCH, E. Landscape: Between place and space. In: Hirsch, E., and O'Hanlon, M. (eds.). The Archaeology of Landscape: Perspectives on Place and Space, Clarendon Press, Oxford, pp. 1-30. 1995.

IBGE. Disponível em: http://www.ibge.gov.br/home/default.php. Acesso em: nov 2012.

Censo 2010. Disponível em: http://censo2010.ibge.gov.br/. Acesso em: jan 2013.

IEMA. Instituto Estadual do Meio Ambiente e Recursos Hídricos. Disponível em: http://www.meioambiente.es.gov.br/default.asp. Acesso em jan 2013.

INGOLD, T. The temporality of landscape. World Archaeology n.25. p.152-174. 1993.

INMET. Instituto Nacional de Meteorologia. Disponível em: http://www.inmet. gov.br/. Acesso em 30 abr 2012.

JOHNSON, M. Ideas of landscape. Oxford: Wiley-Blackwell, 2006.

JORDÃO, P. Análise de proveniência de matérias-primas líticas da indústria de pedra lascada do povoado calcolítico de $\mathbf{S}$. Mamede (bombarral). Tese de Doutorado apresentada ao Programa de Pós-Graduação em Geoarqueologia do Departamento de Geologia da Universidade de Lisboa, 2010.

KLEIN, C., DUTROW, B. Manual de ciências dos minerais. 23.ed. Porto Alegre: Bookman, 2012.

KNAPP, A. B., ASHMORE, W. Archaeological Landscapes: constructed, conceptualized, ideational. In: Archaeologies of Landscape: Contemporary 
Perspectives, edited by W. Ashmore and A.B. Knapp, pp. 1-30. Blackwell Publishers, Oxford. 1999.

KNEIP, A. O Povo da Lagoa: Uso do SIG para Modelamento e Simulação na Área Arqueológica do Camacho. Tese de Doutorado, Museu de Arqueologia e Etnologia da Universidade de São Paulo, 2004.

KNEIP, L. M. Sambaqui do Forte - identificação espacial de atividades humanas e suas implicações (Cabo Frio, RJ - Brasil). Coleção do Museu Paulista, Série de Arqueologia, v.02, p.81-143, 1976.

Pescadores e coletores pré-históricos do litoral de Cabo Frio -

Rio de Janeiro. Tese de Doutorado. Faculdade de Filosofia, Letras e Ciências Humanas/Universidade de São Paulo. São Paulo, 1977. . Sambaquis na pré-história do Brasil. Ciência Hoje, v.06, n.33, jul 1987. KNEIP, L. M., PALLESTRINI, L. O sambaqui da Beirada à luz da metodologia por superfícies amplas - Saquarema, Rio de Janeiro. Dédalo. Revista de Arte e Arqueologia, n.28, 1990.

KIPNIS, R., SCHEEL-YBERT, R. Arqueologia e paleoambientes. In: Souza, C. R. G., Suguio, K., Oliveira, A. M. S., Oliveira, P. E. Quaternário do Brasil. p. 343-362. Ribeirão Preto: Holos Editora, 2005.

LAST, J. The nature of history. In: HODDER, I. et al. Interpreting archaeology Finding menaing in the past. p.141-157. London: Routledge, 1995.

LEMONNIER, P. Les Salines de I'Ouest: Logique technique, logique sociale, Paris/Lille: Editions de la Maison des scienses de l'homme, Presses Uniniversitaires de Lille., 1980.

Elements for an anthropology of technology. Michigan: Museum of Antropological Research, v. 88, 1992.

. "The study of material culture today: toward an anthropology of technical systems," Journal of Anthropological Archaeology, n.05, p.147-186, 1986.

LEONARDOS, O. H. Concheiros Naturais e Sambaquis. Papéis Avulsos, Departamento Nacional de Produção Mineral, Serviços de Fomento da Produção Mineral, n.37, p. 1-119. 1938.

LEROI-GOURHAN, A. Les fouilles préhistoriques: techniques et méthodes. Paris: Picard, 1950. 
LEROI-GOURHAN A. Les structures d'habitats au Paléo-lithique supérieur. In: LUMLEY, H. de (ed.). La Préhistoire française, t. I1: Les civilisations paléolithiques et mésolithiques de la France, p. 656-663. Paris: CNRS, Paris, 1976.

LÉVI-STRAUSS, C. Introdução à obra de Marcel Mauss. In: MAUSS, M. Sociologia e Antropologia. São Paulo: COSACNAIFY, 2003.

LIGHTFOOT, K. G., MARTINEZ, A., SCHIFF, A. M. Daily practice and material culture in pluralistic social settings: an archaeological study of culture change and persistence from Fort Ross, California. In: PREUCEL, R.W., MROZOWSKI, S. A. Contemporary Archaeology in Theory - The new pragmatism. 2.ed. p.191-216. Oxford: Wiley-Blackwell, 2010.

LIMA, T. A. Dos mariscos aos peixes: um estudo zoo-arqueológico de mudança de subsistênciaa na pré-história do Rio de Janeiro. Tese de Doutorado. Faculdade de Filosofia, Letras e Ciências Humanas da Universidade de São Paulo, 1991.

. Ocupações pré-histórica em ilhas do Rio de Janeiro. In: BELTRÃO, M. Arqueologia do Estado do Rio de Janeiro. Rio de Janeiro: Arquivo Público do Estado do Rio de Janeiro, Secretaria do Estado de Justiça, 1995.

Em busca dos frutos do mar: os pescadores-coletores do litoral centro-sul do Brasil, Revista USP, p.270-327, n.44, dez/fev 1999/2000.

MACHADO, C. L. M. Análise dos remanescentes ósseos humanos do sítio arqueológico Corondó, RJ: aspectos biológicos e culturais. Tese de Doutorado. Faculdade de Filosofia, Letras e Ciências Humanas da Universidade de São Paulo, 1983.

Arqueologia e Patrimônio em Empreendimentos Lineares:

Dutovias da Indústria Petrolífera no Espírito Santo. $4^{\circ}$ Simpósio de Arqueologia e Patrimônio de Minas Gerais - Caderno de Resumos. p. 10. Ouro Preto, 2010.

MARTIN, G. Pré-história do nordeste do Brasil. 5. ed. Recife: Editora Universitária/UFPE, 2008.

MARTIN, L.; SUGUIO, K.; FLEXOR, J.-M. Le Quaternaire Marin Du Litoral Brésilien entre Cananéia (SP) et Barra de Guaratiba (RJ). In: Proceedings of the 1978 Internacional Symposium on Coastal Evolution in the Quaternary. São Paulo, 1979.

Informações Adicionais Fornecidas pelos sambaquis na Reconstrução de paleolinhas de Praia Quaternária: Exemplos da Costa do Brasil. Revista de Pré-história, v. 6, p. 128-147, 1984. 
MARTIN, L.; SUGUIO, K. Classificação de costas e evolução geológica das planícies litorâneas quaternárias do sudeste e sul do Brasil. In: ACIESP-SP (org) Simpósio sobre Ecossistemas da costa sul e sudeste brasileira. São Paulo. v. 01, p. 1-28. 1987.

MARTIN, L.; SUGUIO, K.; ARCANJO, J. D.; FLEXOR, J.-M. Coastal quaternary formations of the southern part of the State of Espírito Santo (Brazil). Anais da Academia Brasileira de Ciências. v.68, n.03, p.389-404. 1996.

MARTIN, L.; SUGUIO, K.; DOMINGUEZ, J. M. L.; FLEXOR, J.-M. Geologia do Quaternário Costeiro do Litoral Norte do Rio d Janeiro e do Estado do Espírito Santo. Belo Horizonte:CPRM, 1997.

MAUSS, M. As técnicas corporais. In: MAUSS, M. Sociologia e antropologia. São Paulo: EPU, v.II. pp. 37-184, 1974a

. Ensaio sobre a dádiva: forma e razão da troca nas sociedades arcaicas. In: MAUSS, M. Sociologia e Antropologia. São Paulo: Edusp.1974b. MENDONÇA, F. DANNI-OLIVEIRA, I. M. Climatologia: noções básicas e climas do Brasil. São Paulo: Oficina de Textos, 2007.

MEYER, F. Os sambaquis de Vitória. Brasil odontológico, v. 12, p. 298-99, 1936. MORAIS, J. L. A propósito do estudo das indústrias líticas. Revista do Museu Paulista, v.XXXII, p, 155-184, 1987

Tecnotipologia lítica: a utilização dos afloramentos litológicos pelo homem pré-histórico brasileiro: análise do tratamento da matéria-prima. Erechim: Habilis, 2007.

Perspectivas geoambientais da arqueologia do Paranapanema Paulista. Erechim, RS: Habilis, 2011.

Arqueologia da paisagem. In: Scheunemann, I., Oosterbeek, L. Gestão integrada do território - economia, sociedade, ambiente e cultura (orgs.). Rio de Janeiro: Instituto BioAtlântica, 2012.

NASCIMENTO, D. R., Jr. Dinâmica e sedimentação da Praia da Areia Preta (Guarapari - ES). Trabalho de Conclusão de Curso de Graduação em Geologia da Universidade Federal Rural do Rio de Janeiro (inéd.), 109p. Seropédica - RJ, 2004. NASCIMENTO, D. R., Jr., AGUIAR, V. A. P., GIANNINI, P. C. F. Minerais pesados das areias praiais de Guarapari (ES): distribuição, proveniência e fatores de risco à saúde. Anais da XIII Congreso da Associação Brasileira de estudos do 
Quaternário ABEQUA e III Encontro do Quaternário Sulamericano. Búzios - RJ, 2011.

NEVES, A. O ceramio Sapucaia. Revista do Instituto Histórico e Geográfico do Espírito Santo, n.5, p. 43-50, 1943.

NEVES, P. C. P. das. Introdução à mineralogia prática. 3. ed. Canoas: Ulbra, 2011.

NIMER, E. Climatologia do Brasil. 2ed. Rio de Janeiro: IBGE, 1989.

OLIVEIRA, P. E. de. Paleovegetação e Paleoclimas. . In: Souza, C. R. G., Suguio, K., Oliveira, A. M. S., Oliveira, P. E. Quaternário do Brasil. p. 52-74. Ribeirão Preto: Holos Editora, 2005.

ORSSICH, A. Observações arqueológicas em sambaquis. Revista de Antropologia, v.02, n.01, 1954.

- Relatório arqueológico do Espírito Santo. Revista de cultura da Universidade Federal do Espírito Santo, n.20, 1981.

PALLESTRINI, L. A jazida do Buracão - Km17 da estrada Guarujá-Bertioga. Homenaje a Fernando Márques - Miranda, p.293-322. Publicaciones del Seminario de Estudios Americanistas y del Seminario de Antropologia Americana, Universidade de Madrid e Sevilla, 1964. - Interpretação das estruturas arqueológicas em sítios do Estado de São Paulo. Coleção Museu Paulista, Série Arqueológica, n.01, 1975.

PALLESTRINI, L. Camargo 76, Município de Piraju, Estado de São Paulo. Revista do Museu Paulista, N. S., XXIV: 83-110. São Paulo: Museu Paulista da Universidade de São Paulo, 1977.

PALLESTRINI, L.; CHIARA, P. Indústria lítica de Camargo 76, município de Piraju, Estado de São Paulo. Coletânea do Museu Paulista, Série Ensaios, v.02, p.83-122, 1978.

PALLESTRINI, L., KNEIP, L. M., GOULART, M. L., CHIARA, P., MORAIS, J. L. Ensaios de arqueologia brasileira, v. 1. Rio de Janeiro: Luna, 1982.

PALLESTRINI, L., MORAIS, J. L. de. Arqueologia pré-histórica brasileira. Museu Paulista, Universidade de São Paulo. Fundo de Pesquisas. São Paulo, 1982.

PALLESTRINI, L.; PERASSO, J. A. Arqueología: Metodo y técnicas em Superficies Amplias. Assunción: Biblioteca praguaya de Antropología. v. 4. Centro de Estúdios Antropológicos, Universidad Catolica, 1984. 
PARENTI, F. Le gisement quaternaire de Pedra Furada, Piauí, Brésil: stratigraphie, chronologie, évolution culturelle. Paris: Éditions Recherche sur les Civilisations, 2001.

PATCHINEELAM, S. M. Circulação oceânica. In: Baptista Neto, J. A.; Ponzi, V. R. A., Sichel, S. E. Introdução à Geologia Marinha. 1.ed. p.153-173. Rio de Janeiro: Interciência, 2004.

PEREIRA, O. J. Caracterização fitofisionômica da restinga de Setiba/Guarapari-ES. In: ACIESP (org.). II Simpósio de ecossistemas da costa sul e sudeste brasileira: estrutura, função e manejo n.3, p. 207-219, 1990.

PERLÈS, C. Le Feu. In: LUMLEY, H. de. (Ed.) La préhistorie française. t. 1I, p. 679-683. Paris: CNRS, 1976.

PEROTA, C. Considerações sobre a Tradição Aratu nos Estados da Bahia e Espírito Santo. Boletim do Museu de Arte e História, v.1, Vitória, 1971a.

Dados parciais sobre a arqueologia norte espírito-santense. Programa Nacional de Pesquisas Arqueológicas: resultados preliminares do quarto ano, 1968-1969. Publicações Avulsas do Museu Paraense Emílio Goeldi, v.15, 1971b.

Programa Nacional de Pesquisas Arqueológicas - Resultados preliminares do quinto ano - 1969-1970. Belém: Publicações Avulsas, n.26, Museu Paraense Emílio Goeldi, 1974.

As datações do C-14 dos sítios arqueológicos do Espírito Santo.

Revista de Cultura da Universidade Federal do Espírito Santo, n. 06, 1975.

Sítio Monsarás. São Paulo: Dissertação de Mestrado apresentada ao Programa de Pós Graduação em Antropologia Social da Faculdade de Filosofia, Letras e Ciências Humanas da USP. 1979.

. Evolução da paisagem e transição cultural. Estudos de arqueologia no litoral do Estado do Espírito Santo. Anais do 1ํ Congresso da Associação Brasileira de Estudos do Quaternário. Porto Alegre, 1987.

. Os primeiros habitantes e a Missão Jesuítica - Reis Magos, patrimônio cultural brasileiro. Vitória, 1988.

Os índios de Aracruz. Vitória, 1995.

Relatório do Programa de Resgate em Sítios Arqueológicos na área do empreendimento “LD 138kV RAMAL para SD Lameirão” Guarapari ES. Vitória, 2010. 
PEROTA, C., ASSIS, V. S. de. O sítio Areal: influência da pressão ambiental sobre a população pré-histórica no litoral do Espírito Santo. Revista de Cultura da Universidade Federal do Espírito Santo, n.48, 1993.

PESSENDA, L. C. R. Entrevista. In: FIORAVANTI, C. The ancient Amazonia in Espírito Santo State. Revista Pesquisa FAPESP. n.2, p. 38-43, 2012.

PessendA, L. C. R., GOUVEIA, S. E. M., FReitAS, H. A., RIBEIRO, A. S. ARAVENA, R., BENDASSOLLI, J. A., LEDRU, M. P., SIEFEDDINE, A. F., YBERT, R. S. Isótopos de carbono e suas aplicações em estudos paleoambientais. In: Souza, C. R. G., Suguio, K., Oliveira, A. M. S., Oliveira, P. E. Quaternário do Brasil. p. 75-93. Ribeirão Preto: Holos Editora, 2005.

PESSENDA, L. C. R., VIDOTTO, E. OLIVEIRA, P. E. de, BUSO JR., A. A., COHEN, M. C. L., ROSSETTI, D. F., RICARDI-BRANCO, F. BENDASSOLLI, J. A. Late Quaternary vegetation and coastal environmental changes at llha do Cardoso mangrove, southeastern Brazil. Elsevier, 2012. Disponível em: http://www.journals.elsevier.com/palaeogeography-palaeoclimatology palaeoecology. Acesso em: 29 set. 2014.

PIMENTEL, T. F., SILVA, A. G. A população de Gaylussacia brasiliensis na vegetação arbustiva aberta na Área de Proteção Ambiental de Setiba,

Guarapari, ES. Natureza on line n. 9, p. 76-81. Disponível em: <http://www. naturezaonline.com.br/>. Acesso em: 12 abr 2014.

PLENS, C. L. Sítio Moraes, uma Biografia não Autorizada: Análise do Processo de Formação de um Sambaqui Fluvial. Tese de Doutorado, Museu de Arqueologia e Etnologia da Universidade de São Paulo, São Paulo, 2007.

PMG. Prefeitura Municipal de Guarapari. Plano Local de Habitação e Interesse Social. Guarapari, 2012.

PREUCEL, R.W., MROZOWSKI, S. A. Agency, meaning, and practice. In: PREUCEL, R.W., MROZOWSKI, S. A. Contemporary Archaeology in Theory The new pragmatism. 2.ed. p.129-136. Oxford: Wiley-Blackwell, 2010.

PROUS, A. Os artefatos líticos - elementos descritivos classificatórios. Revista Arqueologia, Museologia e História Natural. v. 11, p. 1-88. Belo Horizonte: UFMG, 1986/1990.

Arqueologia brasileira. Brasília: Universidade de Brasília, 1992. 
PROUS, A., LIMA, M. A. A tecnologia de debitagem do quartzo no centro de Minas Gerais: lascamento bipolar. Revista Arqueologia, Museologia e História Natural. v. 11, n. 91-111. Belo Horizonte: UFMG, 1986/1990.

RADAM BRASIL, Levantamento de recursos naturais (Mapa). Folha Rio de Janeiro/ Vitória. 1983.

RENFREW, C. Monuments, Mobilizationan and Social Organization in Neo-lithic Wessex. In: The Explanation of Culture Change, Renfrew, C. ed., pp. 39-558. London: Duckworth, 1973.

RIOS, E.C. Seashells of Brazil. Rio Grande: Fundação Universidade do Rio Grande e Fundação Cidade do Rio Grande, 1985.

RUSCHI, A. Contribuições da Arqueologia de Santa Tereza, no Estado do Espírito Santo. Objetos de Pedra de Origem Indígena. Boletim do Museu de Biologia Professor Mello Leitão, v. 01, 1953.

. Grupos antropológicos indígenas do Estado do Espírito Santo. Causas de seu desaparecimento. Dados sobre a população e a área de floresta para a sua sobreviência. Com um mapa. Boletim do Museu de Biologia Professor Mello Leitão, série Proteção à Natureza, n. 18, 1954.

SANCHES, R. P., FERREIRA, C. P. Modelando a dispersão da doença do caranguejo letárgico entre estuários. Matemática aplicada computacional. v. 11, n. 03, p. 231-244. 2010. Disponível em:<http://www.sbmac.org.br/ tema/seletas /docs/v11_3/Sanches_Ferreira.pdf>. Acesso em 29 set 2014.

SANTOS, M. A. Por uma geografia nova: da crítica da geografia a uma geografia crítica. São Paulo: Hucitec, 1978.

. Pensando o espaço do homem. São Paulo: Hucitec, 1997.

. Da totalidade ao lugar. São Paulo: EDUSP, 2005.

. Espaço e método. 5.ed. São Paulo: EDUSP, 2008.

SCATAMACHIA, M. C. Proposta de diagnóstico prospectivo Ramal GASCAV UTG - Sul. Museu de Arqueologia e Etnologia da Universidade de São Paulo, 2007.

. Projeto de salvamento arqueológico Ramal GASCAV - UTG -

Sul. Museu de Arqueologia e Etnologia da Universidade de São Paulo, 2008.

SCHAMA, S. Paisagem e Memória. Tradução de Hildegard Feist. São Paulo: Cia. das Letras, 1995.

SHACKEL, P. A. Public memory and the search for power in American historical archaeology. In: PREUCEL, R.W., MROZOWSKI, S. A. Contemporary 
Archaeology in Theory - The new pragmatism. 2.ed. p.385-403. Oxford: WileyBlackwell, 2010.

SCHEEL-YBERT, R., GOUVEIA, S. R. M., PESSENDA, L. C. R., ARAVENA, R., COUTINHO, L. M., BOULET, R. Holocene palaeoenvironmental evolution in the São Paulo State (Brazil), based on anthracology ans soil $\delta{ }^{13} \mathrm{C}$ analysis. The Holocene, v. 13, n. 1, p. 73-81. 2003.

SEAMA. Reserva Estadual de Desenvolvimento Sustentável (RDS) Concha D'Ostra. Disponível em:< http://www.meioambiente.es.gov.br/> Acesso em: 03 set 2014.

SHANKS, M., TILLEY, C. Reconstructing archaeology: theory and practice. London: Routledge, 1992.

SILVA, S. F. S. M. da, Um outro olhar sobre a mortearqueologia e imagem de enterramentos humanos no catálogo de duas coleções - Tenório e Mar Virado, Ubatuba, São Paulo. Dissertação de Mestrado. Museu de Arqueologia e Etnologia da Universidade de São Paulo, 2001.

Arqueologia das práticas mortuárias em sítios pré-históricos do litoral do Estado de São Paulo. Tese de Doutorado. Museu de Arqueologia e Etnologia da Universidade de São Paulo, São Paulo, 2005.

SILVA, M. A., CAMOZZATO, E., PAES, V. J. C., JUNQUEIRA, P. A., RAMGRAB, G. E. Folha SF.24 - Vitória. In: Schobbenhaus et al. (Orgs.). Carta Geológica do Brasil ao Milionésimo (CD-ROM). Brasília: CPRM, 2004.

SIMÕES, C. B. O panorama da ocupação sambaquieira no arquipélago de Ilhabela, SP. Tese de Doutorado. Museu de Arqueologia e Etnologia da Universidade de São Paulo, 2014.

SMMA. Secretaria Municipal de Meio Ambiente de Guarapari. Projeto "Fossas sépticas sub-bacia do rio Perocão contemplando Perocão e Jabaraí, 2007.

SOUZA, L. S. Moranduba, Tupinambá e Amboaé - arqueologia do Espírito Santo, de Reritiba a Anchieta. Dissertação de Mestrado. Museu Nacional da Universidade Federal do Rio de Janeiro. Rio de Janeiro, 2010.

SUGUIO, K. Geologia Sedimentar. São Paulo: Editora Edgard Blücher, 2003. . Introdução. In: Souza, C. R. G., Suguio, K., Oliveira, A. M. S., Oliveira,

P. E. Quaternário do Brasil. p. 21-27. Ribeirão Preto: Holos Editora, 2005. Geologia do Quaternário e mudanças ambientais. São Paulo: Oficina de Textos, 2010. 
SUGUIO, K.; MARTIN, L; DOMINGUEZ, J. M. L.; Evolução da planície costeira do rio Doce (ES) durante o quaternário: influência das flutuações do nível do mar. Simpósio do Quaternário no Brasil, n.04, Rio de Janeiro: Atas, 1982.

SUGUIO, K.; MARTIN, L; BITTENCOURT, A.; DOMINGUEZ, J.; FLEXOR, J.-M.; AZEVEDO, A. Flutuações do Nível Relativo do Mar Durante o Quaternário Superior ao Longo do Litoral Brasileiro e suas implicações na sedimentação Costeira. Revista Brasileira de Geociências, v. 15, p. 273-286, 1985.

SUGUIO, K., TESSLER, M. G. (1984) Planícies de cordões litorâneos Quaternários do Brasil: Origem e nomenclatura. In: LACERDA, L. D., ARAÚJO, D. S. D., CERQUEIRA, R., TURCO, B. (orgs). Restingas, Origem, Estrutura e Processos. Niterói, L.D. Rio de Janeiro: Centro Editorial da Universidade Federal Fluminense, p. 32-56, 1984.

TENÓRIO, M. C. Estabilidade dos grupos litorâneos pré-históricos: uma questão para ser discutida. In: BELTRÃO, M. Arqueologia do Estado do Rio de Janeiro. Rio de Janeiro: Arquivo Público do Estado do Rio de Janeiro, Secretaria do Estado de Justiça, 1995.

Identidade cultural e origem dos sambaquis. Revista do Museu de Arqueologia e Etnologia, n.14, 2004.

TEIXEIRA, J. L. C. A malha paralela no levantamento arqueológico regional - um estudo de caso na planície litorânea do norte capixaba - Brasil. Dissertação de Mestrado. Museu de Arqueologia e Etnologia da Universidade de São Paulo, 2002.

TILLEY, C. A phenomenology of landscape, places, paths and monuments. In: A phenomenology of landscape, edited by C. Tilley, pp. 7-34. Berg, Oxford. 1994. TIXIER, J. Préhistorique de la Pierre taillé 1: terminologie et technologie. Antibes: Cercle de Recherches et d'Estudes Préhistoriques, 1980.

TRIGGER, B. G. The Determinants of Settlement Patterns. In: Settlement Archaeology, Chang, K. C. ed., pp.5 3-78. Palo Alto, C A:National Press (Mayfield). 1968.

História do pensamento arqueológico. São Paulo: Odysseus, 2004.

UCHÔA, D. P. Arqueologia de Piaçaguera e Tenório: análises de dois tipos de sítios pré-cerâmicos do oeste paulista. Tese de Doutorado apresentada à Faculdade de Ciências e Letras de Rio Claro, Setor de Antropologia, Arqueologia e Etnologia. Rio Claro, 1973. 
Desgastes dentários em populações brasileiras extintas: o sambaqui de Piaçaguera, São Paulo, Brasil. Arquivo de Anatomia e Antropologia, v.38, p. 147-158, Lisboa, 1980.

Arqueologia de Piaçaguera e Tenório: análise de dois tipos de sítios pré-cerâmicos do litoral Paulista. Erechim, RS: Habilis, 2007. . A ilha do Mar Virado: Estudo de um sítio arqueológico no litoral norte do Estado de São Paulo. Clio. Série Arqueológica, v.24, n.01, 2009.

VAN DER LEEUW, S. E. Giving the potter a choice: conceptual aspects of pottery techniques. In: LEMMONIER, P. (org.). Technological choices: transformation in material cultures since the Neolithic. London: Routledge, 1993.

VELOSO, H. P., RANGEL FILHO, A. L., LIMA, J. C. A. Classificação da vegetação brasileira, adaptada a um sistema universal. Rio de Janeiro: IBGE, 1991.

VERÍSSIMO, N. P.; SAFFORD, H. F., BEHLING, H. Holocene vegetation and fire history of the Serra do Caparaó, SE Brazil. Holocene. n. 22, v. 11, p. 1243-1250, 2012.

VILLAGRÁN, X. S. Micromorfologia de sítios concheiros da América do Sul: arqueoestratigrafia e processos de formação de sambaquis (Santa Catarina, Brasil) e concheiros (Terra do Fogo, Argentina). Tese de Doutorado apresentada ao Instituto de Geociências da USP, 2012.

VILLWOCK, J. A., LESSA, G.C., SUGUIO, K., ANGULO, R. J., DILLEMBURG, S. R. Geologia e geomorfologia de regiões costeiras. In: SOUZA, C. R. G., SUGUIO K., OLIVEIRA, M. A.S. (ed) Quaternário do Brasil. Ribeirão Preto, SP: Ed. Holos, p. 92-113, 2005.

WILLEY, G. Prehistoric Settlement Patterns in the Vird Valley, Peru. BAE Bulletin 155.Washington, DC: U.S. Government Printing Office. 1953.

WILLEY, G.; PHILIPS, P. Method and Theory in American Archaeology. University of Chicago Press: Chicago, 1958.

YAR, B., DUBOIS, P. Les structures d'habitat au Paléolithique inférieur et moyen en France: entre réalité et imaginaire. Bulletin de la Société préhistorique française. Tome 93, n. 2, p. 149-463. 1996.

ZEDEÑO, M. N. Landscapes, land use, and the history of territory formation: an example from the puebloan southwest. Journal of Archaeological Method and Theory, v.04, n.01, 1997. 
ZEDEÑO, M. N., BOWSER, B. J. The archaeology of meaningful places. The archaeology of meaningful places. pp. 1-15. Texas: Texas Tech University, 2009. 
ANEXOS 
MAPA GEOLÓGICO DO ESPÍRITO SANTO COM DESTAQUE PARA O MUNICÍPIO DE GUARAPARI
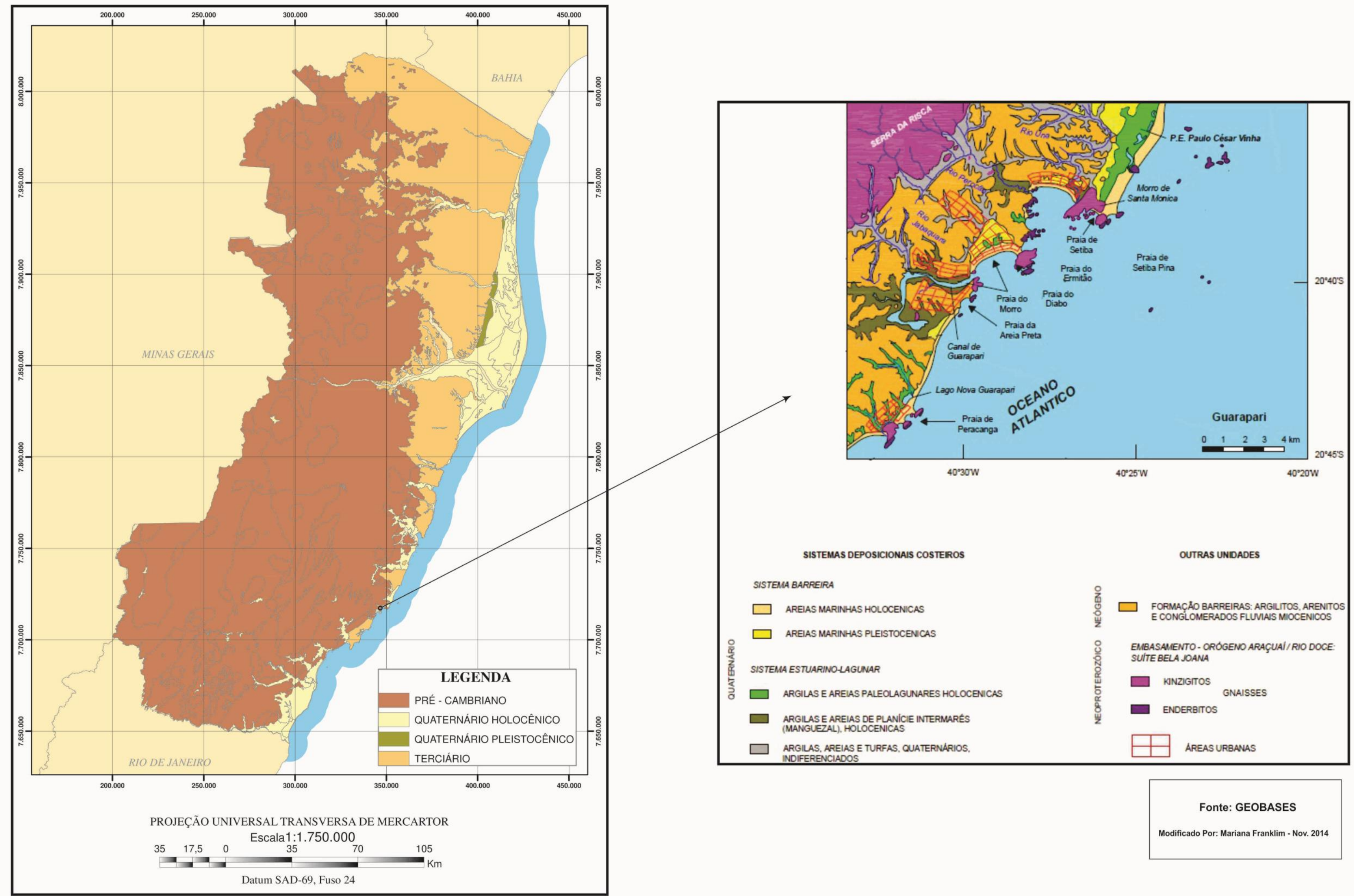

Fonte: GEOBASES Modificaado Por: Mariana Frankkim - Novr. 2014 
MAPA PEDOLÓGICO

\section{VARIANTE GUARAPARI-PIÚMA-SÃO JOSÉ DO FRADE}

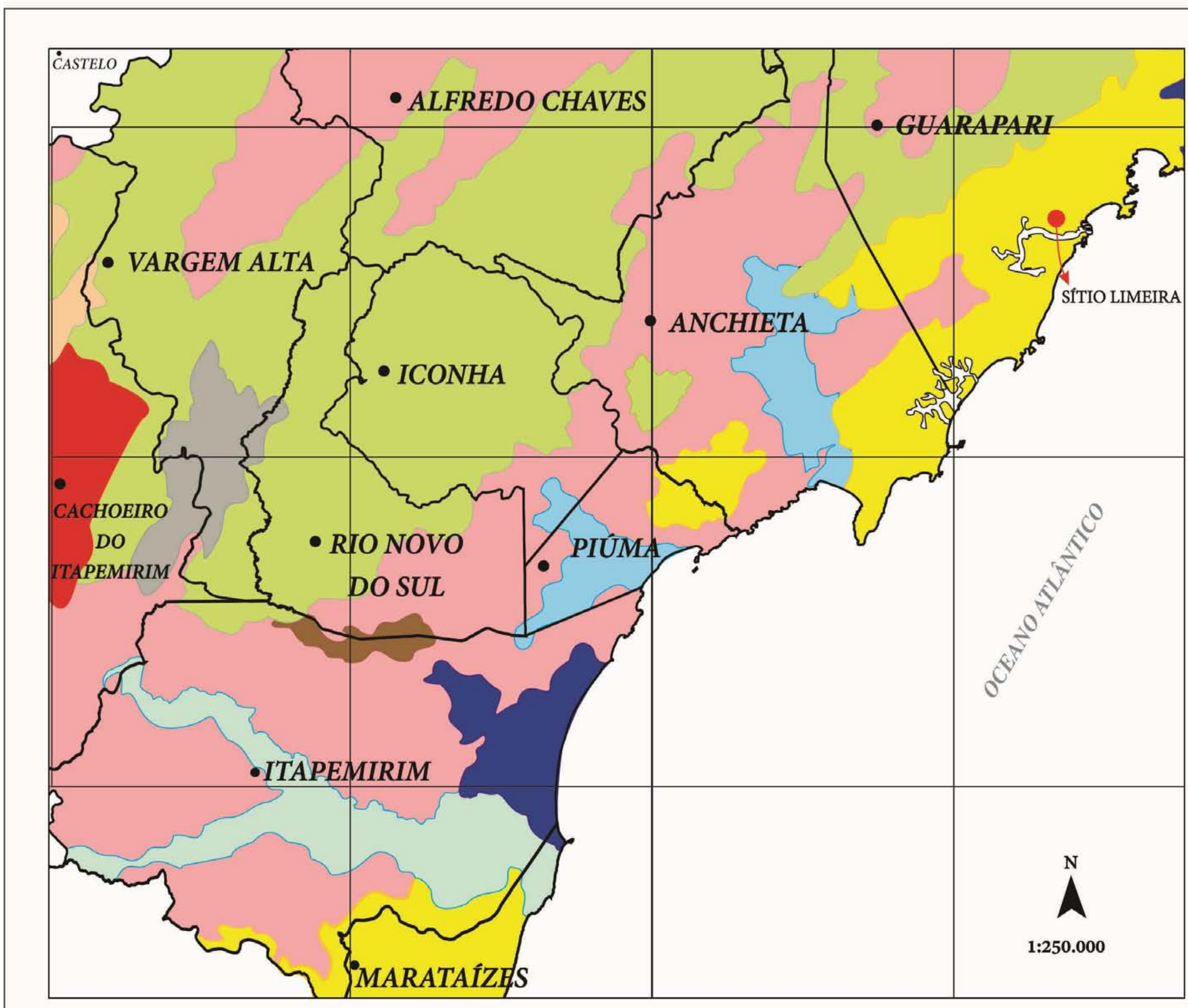

\section{LEGENDA}

AFLORAMENTO ROCHOSOS BRUNIZÉM

CAMBISSOLO

GLEISSOLO

LATOSSOLO VERMELHO-AMARELO

PODZÓLICO HIDROMÓRFICO

PODZÓLICO AMARELO

PODZÓLICO VERMELHO-AMARELO

PODZÓLICO VERMELHO-ESCURO

PODZÓLICO VERMELHO-ESCURO

SOLOS ALUVIAIS

SOLOS LITÓLICOS

SOLOS ORGÂNICOS 


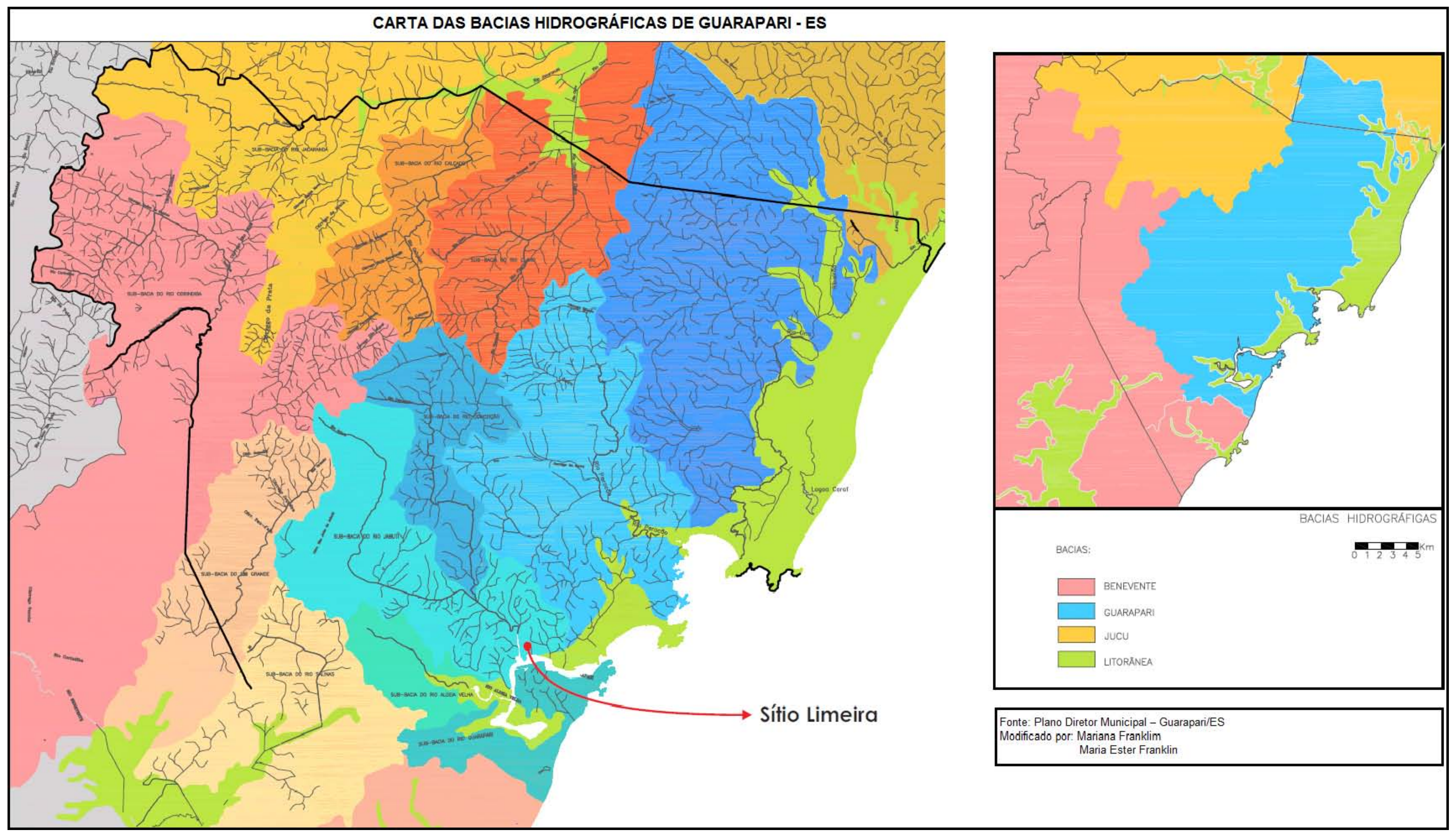


ANEXO D: Mapa hidrográfico de Guarapari-ES.

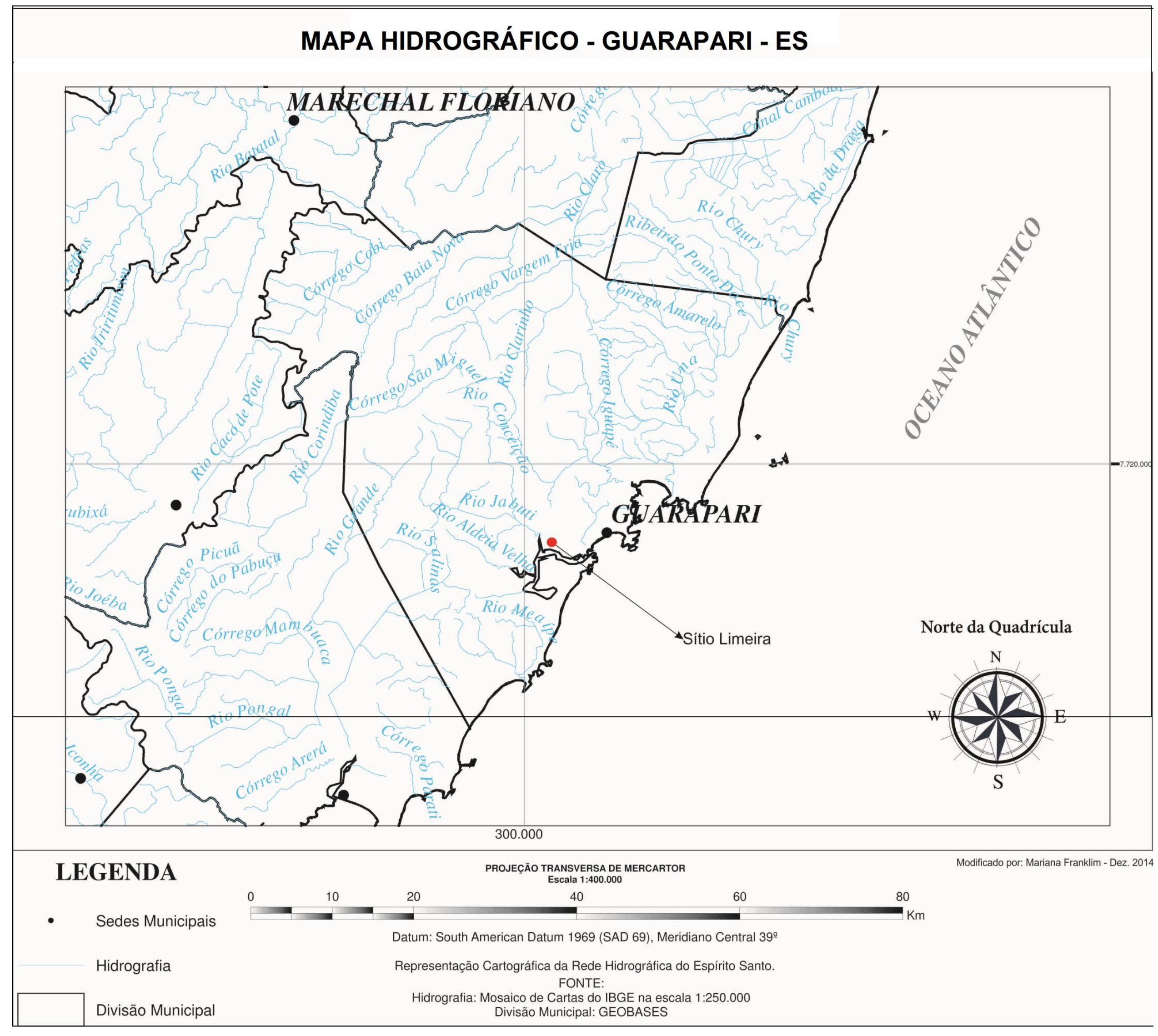


